\begin{abstract}
UNIVERSIDADE DE SÃO PAULO
FACULDADE DE FILOSOFIA, LETRAS E CIÊNCIAS HUMANAS

PROGRAMA DE PÓS-GRADUAÇÃO EM LÍNGUA, LITERATURA E CULTURA

ITALIANAS
\end{abstract}

Suellen Bellentani da Silva

\begin{abstract}
A CONSTRUÇÃO DA IDENTIDADE E DA MEMÓRIA EM DEZ ENTREVISTAS DE DESCENDENTES DE ITALIANOS EM SÃO

PAULO: COZINHA, LÍNGUA ITALIANA E FAMÍLIA
\end{abstract}

VERSÃO CORRIGIDA 


\title{
A CONSTRUÇÃO DA IDENTIDADE E DA MEMÓRIA EM DEZ ENTREVISTAS DE DESCENDENTES DE ITALIANOS EM SÃO PAULO: COZINHA, LÍNGUA ITALIANA E FAMÍLIA
}

\section{VERSÃO CORRIGIDA}

\author{
Dissertação de Mestrado apresentada ao \\ programa de Pós-Graduação em Língua, \\ Literatura e Cultura Italianas do Departamento \\ de Letras Modernas da Faculdade de Filosofia, \\ Letras e Ciências Humanas da Universidade \\ de São Paulo. \\ Área de concentração: $O$ italiano falado e \\ escrito sob a perspectiva brasileira \\ Orientadora: Professora Dra. Giliola Maggio
}


Autorizo a reprodução e divulgação total ou parcial deste trabalho, por qualquer meio convencional ou eletrônico, para fins de estudo e pesquisa, desde que citada a fonte.

Catalogação na Publicação Serviço de Biblioteca e Documentação

Faculdade de Filosofia, Letras e Ciências Humanas da Universidade de São Paulo

d586c

da Silva, Suellen Bellentani

A construção da identidade e da memória em dez entrevistas de descendentes de italianos em São

Paulo: cozinha, língua italiana e família / Suellen

Bellentani da Silva; orientadora Giliola Maggio - São Paulo, 2021.

$204 \mathrm{f}$.

Dissertação (Mestrado) - Faculdade de Filosofia, Letras e Ciências Humanas da Universidade de São Paulo. Departamento de Letras Modernas. Área de concentração: Língua, Literatura e Cultura Italiana.

1. Imigração italiana. 2. Língua italiana. 3. Memória. 4. Identidade. I. Maggio, Giliola, orient. II. Título. 


\title{
ENTREGA DO EXEMPLAR CORRIGIDO DA DISSERTAÇÃO/TESE
}

\section{Termo de Ciência e Concordância do (a) orientador (a)}

\author{
Nome do (a) aluno (a): Suellen Bellentani da Silva
}

Data da defesa: 18/06/2021

Nome do Prof. (a) orientador (a): Giliola Maggio

Nos termos da legislação vigente, declaro ESTAR CIENTE do conteúdo deste EXEMPLAR CORRIGIDO elaborado em atenção às sugestões dos membros da comissão Julgadora na sessão de defesa do trabalho, manifestando-me plenamente favorável ao seu encaminhamento e publicação no Portal Digital de Teses da USP.

São Paulo, 18/08/2021

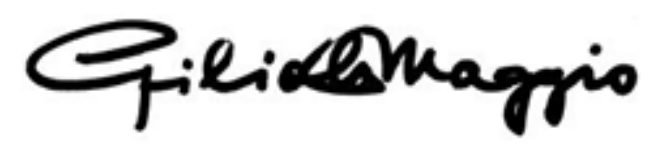

(Assinatura do (a) orientador (a) 


\section{FOLHA DE APROVAÇÃO}

Silva, Suellen Bellentani

A construção da identidade e da memória em dez entrevistas de descendentes de italianos em São Paulo: cozinha, língua italiana e família

Dissertação apresentada ao programa de Pós-Graduação em Língua, Literatura e Cultura Italianas do Departamento de Letras Modernas da Faculdade de Filosofia, Letras e Ciências Humanas da Universidade de São Paulo para obtenção do título de Mestre em Letras.

Área de concentração: O italiano falado e escrito sob a perspectiva brasileira

Aprovada em:

Banca Examinadora

Prof.(a) Dr.(a)

Instituição:

Assinatura:

Prof.(a) Dr.(a)

Instituição:

Assinatura:

Prof.(a) Dr.(a)

Instituição:

Assinatura:

Prof.(a) Dr.(a)

Instituição:

Assinatura: 
À minha avó, com amor, pela inspiração. 


\section{AGRADECIMENTOS}

À minha orientadora, professora Giliola Maggio, que tive o prazer de conhecer em minhas aulas de língua italiana, que me guiou com maestria pelo caminho acadêmico e que me apoiou em todos os momentos, obrigada por todo carinho e inspiração.

À professora Elisabetta Santoro, que me incentivou e contribuiu com muitas ideias para esse trabalho tornar-se realidade.

À CAPES-DS pela bolsa de pesquisa.

Ao meu amigo, Luís Pecorelli, pelas conversas, ideias, cafés e por me fazer acreditar que daria certo.

À minha mãe, pelo apoio imensurável, pelo amor, pela paciência e pela tranquilidade. Obrigada por me apoiar pelo caminho que escolhi seguir. Aos meus familiares, por se manterem sempre ao meu lado em todos os momentos desta caminhada. Aos meus padrinhos, por sempre compreenderem minha ausência e sempre me incentivarem.

À minha avó, a quem dedico este trabalho, por sempre me fazer refletir sobre minhas origens, pelo amor e pelo cuidado.

Minha gratidão ao meu amigo Bruno Bertalha, pela preocupação e por estar sempre pronto para me ouvir e me acalmar durante muitos momentos.

Aos meus amigos da graduação, Marcus Martins, Tábita, Karina e Marcus Lago, por me acompanharem durante essa trajetória e por me apoiarem. A vida acadêmica ficou mais leve com a companhia de vocês. À Lívia, pelo carinho e revisões em língua inglesa.

Ao meu amor e companheiro de vida, Henrique Lima, pelas revisões, pelo apoio, incentivo e por iluminar os meus dias. 
"Somos nossa memória,

Somos esse quimérico museu de formas inconstantes,

Esse amontoado de espelhos quebrados." (BORGES, 2009, p.29) 


\section{RESUMO}

SILVA, Suellen B. A construção da identidade e da memória em dez entrevistas de descendentes de italianos em São Paulo: cozinha, língua italiana e família. 2021. 204 f. Dissertação (Mestrado) - Faculdade de Filosofia, Letras e Ciências Humanas, Universidade de São Paulo, São Paulo, 2021.

O movimento de imigração italiana para o Brasil ocorreu no século XIX até meados do século XX. Assim, o país recebeu cerca de um milhão de italianos e grande parte se concentrou no Estado de São Paulo. Esta pesquisa nasce a partir de projetos de Extensão da Faculdade de Filosofia, Letras e Ciências Humanas da Universidade de São Paulo, junto aos quais coletamos entrevistas com descendentes de italianos. Nesse contexto, escolhemos dez entrevistas para compor o corpus de análise, cujo objetivo foi analisar as características e as manifestações da identidade e da memória nesses descendentes. Transcrevemos as entrevistas e fizemos a análise a partir das categorias de "cozinha", "língua italiana" e "família", observando as ocorrências de palavras relacionadas nas narrativas dos entrevistados. Para o aporte teórico, escolhemos Cenni (2011), Trento (1989) e Klein (1989) sobre os estudos da imigração italiana; utilizamos Bauman (2005) e Hall (2019) a respeito dos conceitos de identidade; adotamos a metodologia de História Oral abordada por Meihy (1996); os estudos de Montanari (2009) sobre a cozinha italiana e os conceitos de memória coletiva de Halbwachs (2003). Desse modo, pudemos observar que os entrevistados mostraram uma ligação com as histórias familiares, que mantêm hábitos alimentares italianos, preservam as memórias da família, além de destacar a importância da língua italiana, que mesmo sem ser transmitida às demais gerações, se faz presente nas entrevistas. Os resultados mostraram que os descendentes apresentam uma identidade que se comporta como italiana e brasileira simultaneamente. Eles se orgulham da história da família, da trajetória dos antepassados e tentam manter o vínculo com a Itália, seja através da língua ou da comida. É possível concluir que a identidade desses entrevistados é fragmentada e inconstante e que vive ao lado da brasileira. Esperamos que essa pesquisa possa contribuir para entender como a presença italiana se manifesta nos descendentes e estimular a continuidade dos estudos nesse âmbito.

Palavras-chave: imigração italiana; identidade; memória; língua italiana; 


\begin{abstract}
SILVA, Suellen B. Constructing identity and memory in ten interviews with descendants of Italian immigrants in São Paulo: food, family, and Italian language. 2021. 204 f. Dissertation (Masters) - Faculty of Philosophy, Languages, and Human Sciences, University of São Paulo, São Paulo, 2021.
\end{abstract}

The Italian immigration movement to Brazil occurred from the late 19th century to the mid-20th century. Consequently, the country welcomed around one million Italians, and the majority established residence in the state of São Paulo. This research arises from the project developed in the Extension Program of Faculty of Philosophy, Languages, and Human Sciences of the University of São Paulo, in which we have gathered interviews with descendants of Italian immigrants. In this context, we selected ten interviews to build our corpus to analyze the features and manifestations of identity and memory of those descendants. We transcribed the interviews and conducted the analysis based on the "food", "Italian language", and "family" categories regarding the occurrences of related words in the narratives of the people interviewed. For the theoretical input, we chose Cenni (2011), Trento (1989), and Klein (1989) for the studies on Italian immigration; for identity concepts, we used Bauman (2005) and Hall (2019); we adopted the Oral History methodology developed by Meihy (1996), as well as studies conducted by Montanari (2009) on Italian culinary and the concepts of collective memory by Halbwachs (2003). Thus, we were able to observe the interviewees experiencing a connection with their families' background, which supports the Italian eating and cooking habits, preserves family memories, in addition to highlighting the importance of the Italian language that, although not passed on to the next generations, is present during the interviews. The results showed that the descendants manifest an identity that behaves simultaneously as Italian and Brazilian. They pride themselves on their family history, their ancestors' journey and they attempt to maintain their bond with Italy alive, whether through language or food. It is reasonable to conclude that the identities of those interviewed are fragmented, changeable, and coexist with the Brazilian character. We expect this research can contribute to the understanding of how the Italian presence manifests in the descendants and encourage the continuation of studies in this scope.

Keywords: Italian immigration; identity; memory; Italian language; 


\section{RIASSUNTO}

SILVA, Suellen B. A construção da identidade e da memória em dez entrevistas de descendentes italianos em São Paulo: cozinha, língua italiana e família. 2021. 204 f. Dissertação (Mestrado) - Faculdade de Filosofia, Letras e Ciências Humanas, Universidade de São Paulo, São Paulo, 2021.

II movimento d'immigrazione italiana verso il Brasile si verifica fra il XIX secolo fino alla metà del XX. In questo modo, il paese ha accolto circa un milione di italiani e grande parte si è concentrata nello Stato di São Paulo. Questa ricerca nasce dai progetti sviluppati presso il programma di Extensão della Faculdade de Filosofia, Letras e Ciências Humanas dell'Universidade de São Paulo. In questo contesto sono state raccolte circa 25 interviste con discendenti di italiani e ne sono state scelte dieci per comporre il corpus di analisi, in cui obiettivo è stato di analizzare le caratteristiche e le manifestazioni dell'identità e della memoria in questi discendenti. Abbiamo trascritto le interviste e analizzato le categorie "cucina", "lingua italiana" e "famiglia", osservando le occorrenze di parole correlate nelle narrative degli intervistati. Come apporto teorico abbiamo scelto Cenni (2011), Trento (1989) e Klein (1989) per gli studi dell'immigrazione italiana; Bauman (2005) e Hall (2019) per quanto riguarda i concetti d'identità; abbiamo adottato la metodologia della Storia Orale, di Meihy (1996); gli studi di Montanari (2009) sulla cucina italiana e i concetti di memoria collettiva di Halbwachs (2003), hanno anche fatto parte della riflessione. Abbiamo, a questo punto, potuto osservare che gli intervistati hanno dimostrato un legame con i ricordi familiari, che mantengono le abitudini alimentari italiane, conservano le memorie della famiglia, oltre al legame con la lingua italiana e la sua importanza, la quale nonostante non sia stata trasmessa ai discendenti è presente nelle interviste. I risultati hanno dimostrato che i discendenti presentano un'identità che si comporta di forma sia italiana che brasiliana, contemporaneamente. Si orgogliano della loro storia familiare, della traiettoria degli antenati e cercano di mantenere il vincolo con l'Italia, sia attraverso la lingua che attraverso il cibo. È possibile concludere che l'identità degli intervistati è frammentata e volubile, e quindi l'identità italiana vive accanto a quella brasiliana. Pertanto, ci auguriamo che questa ricerca contribuisca alla comprensione della presenza italiana che si manifesta nei discendenti e stimoli la continuità degli studi in questo ambito.

Parole chiave: immigrazione italiana; identità; memoria; lingua italiana; 


\section{LISTA DE FIGURAS}

Figura 1 - Gráfico com o índice de ocorrências de palavras da categoria "comida" nas entrevistas. .65

Figura 2 - Gráfico com o índice de ocorrências de palavras da categoria "língua" nas entrevistas. 66

Figura 3 - Gráfico com o índice de ocorrências de palavras da categoria "família" nas entrevistas. 


\section{LISTA DE QUADROS}

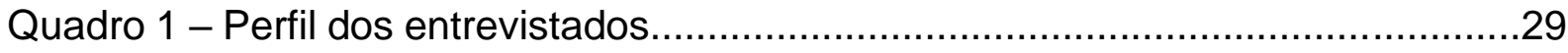

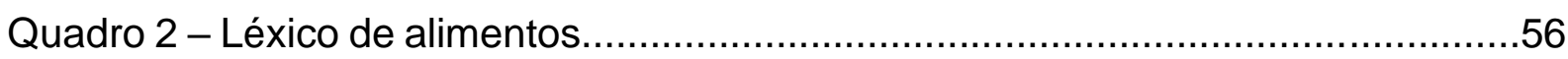

Quadro 3 - Ocorrências de palavras relacionadas à cozinha......................................63

Quadro 4 - Ocorrências de palavras relacionadas à língua.......................................64

Quadro 5 - Ocorrências de palavras relacionadas à família.......................................64 


\section{INTRODUÇÃO}

\section{SUMÁRIO}

2. UM BREVE OLHAR SOBRE A IMIGRAÇÃO ITALIANA ….............................17

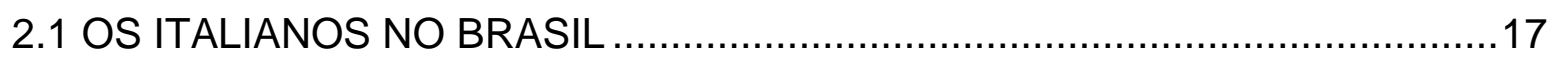

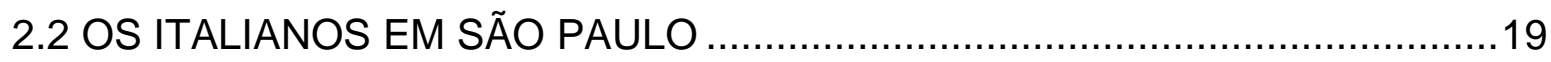

2.3 A LÍNGUA ITALIANA EM SÃO PAULO E OS MEIOS DE COMUNICAÇÃO ...22

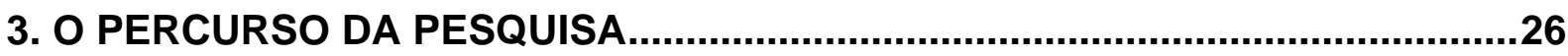

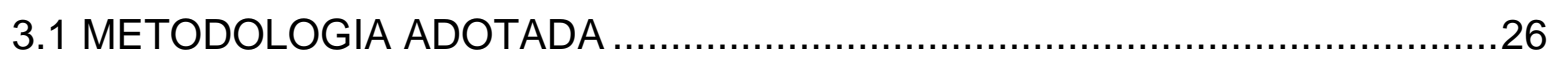

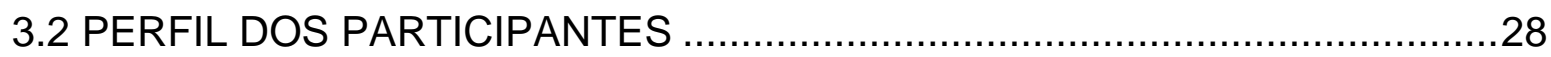

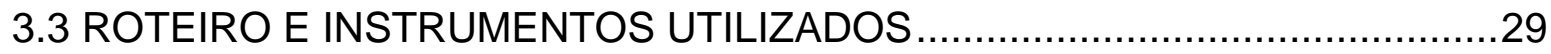

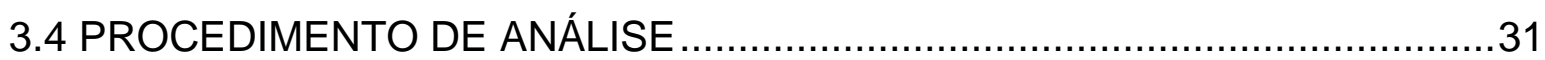

4. CONSTRUINDO A IDENTIDADE: MEMÓRIAS DA "COZINHA", DA "LÍNGUA

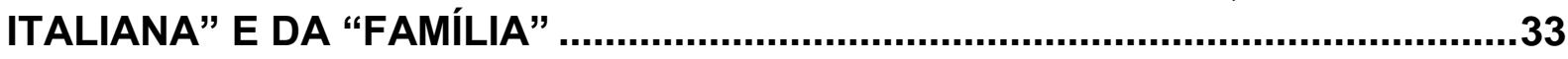

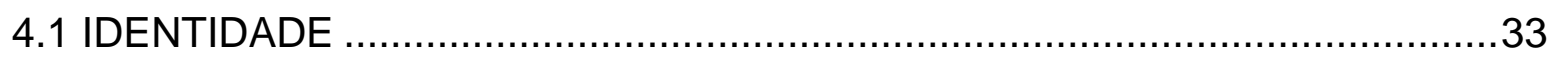

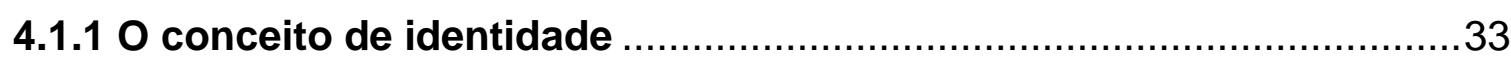

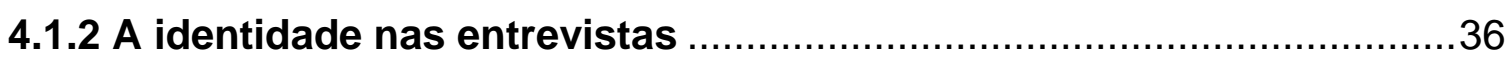

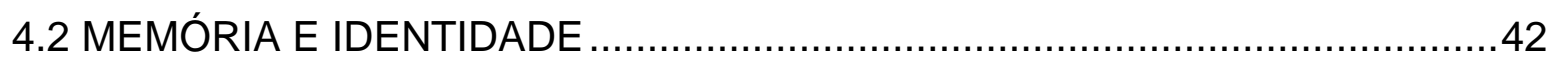

4.2.1 A memória e a construção da identidade .........................................42

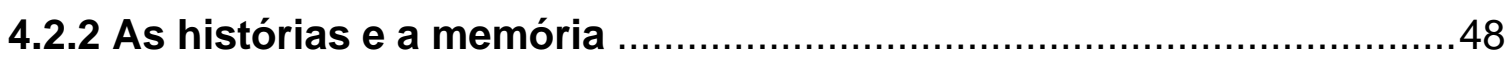

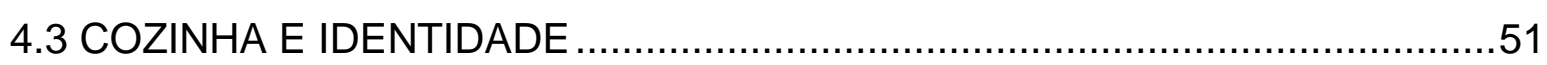

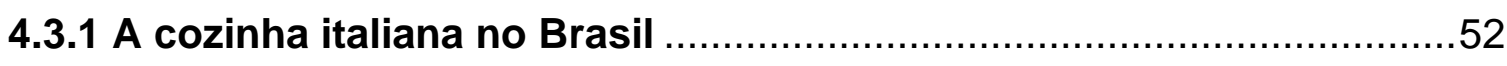

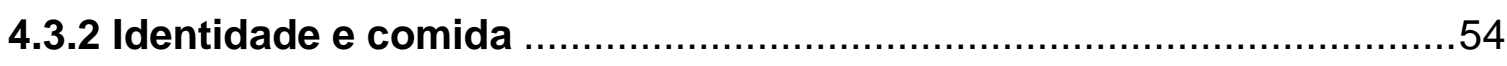

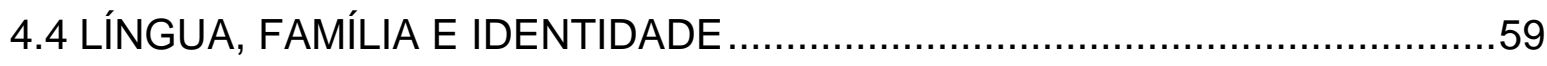

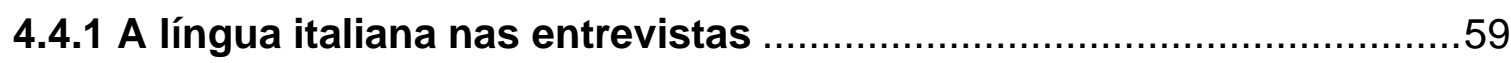

4.4.2 A língua como condutora de identidades e memórias .......................63

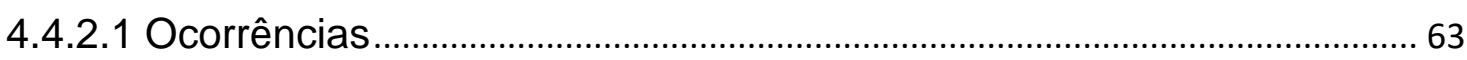

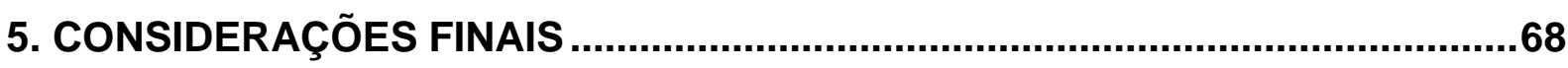

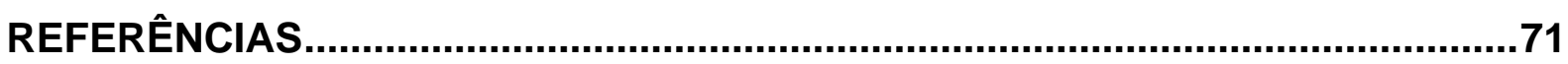

APÊNDICE A - Transcrição da entrevista 01 ….............................................73

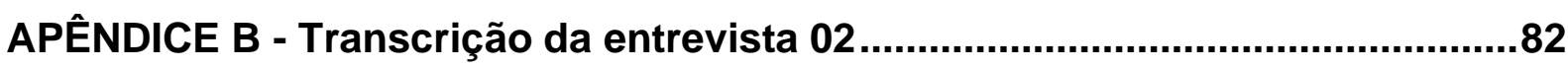

APÊNDICE C - Transcrição da entrevista 03 ..................................................99

APÊNDICE D - Transcrição da entrevista 04..............................................110

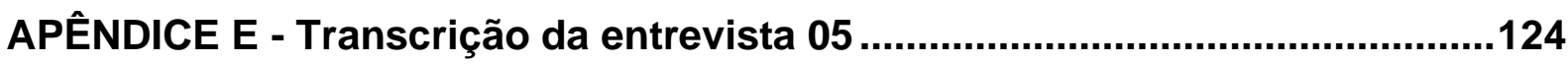

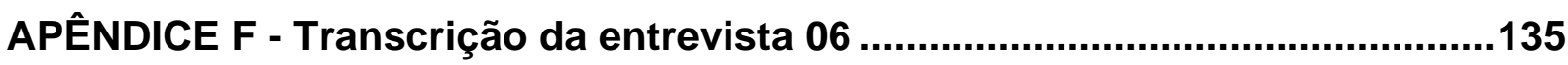

APÊNDICE G - Transcrição da entrevista 07.................................................144 
APÊNDICE H - Transcrição da entrevista 08 ..............................................162

APÊNDICE I - Transcrição da entrevista 09..............................................175

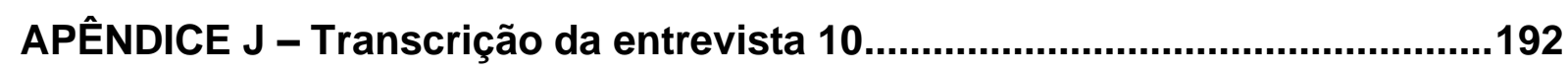

ANEXO II - Normas utilizadas para transcrição ...............................................204 


\section{INTRODUÇÃO}

O processo de imigração no Brasil deixou fortes marcas na cultura e na vida do país. Após o fim do tráfico negreiro, que terminou em meados de 1850, no século XIX iniciou a imigração dos povos europeus para o Brasil e os imigrantes italianos, que estiveram entre os grupos numericamente mais significativos, se estabeleceram, na maior parte dos casos, no Estado de São Paulo, nas plantações de café, tendo depois ocupado as cidades e se tornado, muitas vezes, empreendedores. Klein (1989) afirma que o Brasil, a Argentina e os Estados Unidos foram os países americanos que mais receberam imigrantes italianos durante o período da maior migração intercontinental da Europa.

Dessa forma, minha motivação de investigar os fatores envolvidos, a história e as memórias desses imigrantes nascem da existência dessa grande comunidade italiana em São Paulo. Nesse sentido, as primeiras pesquisas sobre "O italiano dos italianos de São Paulo", surgem por volta do início dos anos Noventa com as professoras Loredana de Stauber Caprara e Olga Alejandra Mordente, abrindo caminho para uma nova linha de investigação linguística, atestando a existência não só de uma presença italiana na arquitetura, na comida e na cultura em geral, mas também na língua, mantida até aquele momento sempre à margem. Tais pesquisas tiveram diversos alunos de Iniciação Científica e, em 1997 o primeiro trabalho que, mais tarde, se transformou no primeiro mestrado, sob orientação da prof.a Caprara, realizado por Marilisa Bertechini Bilia, "Análise Lexical das Interferências da Língua Portuguesa na Língua Italiana falada por italianos de Nível Universitário Residentes na Cidade de São Paulo" (1998). Esse foi o ponto de partida de tantas outras pesquisas na linha de pesquisa "O italiano falado e escrito sob a perspectiva brasileira"1, avançando da capital para o interior do estado de São Paulo. Nesse âmbito, é relevante mencionar o doutorado de Giliola Maggio, "Pedrinhas Paulista: Memória e Invenção (2002) e os mestrados de Liana Laganá Fernandes, "Língua e alimentação: dois elementos da identidade italiana em Pedrinhas Paulista" (2006), Marisa Castellano Tsai, "Palavras da memória: uma análise lexical das interferências da língua portuguesa na língua italiana falada por italianos na cidade de São Paulo" (2008) e de Sonia Galuchi, "São Bernardo do Campo: os imigrados italianos entre a

\footnotetext{
${ }^{1}$ A referida linha de pesquisa, ao longo dos anos, passou por revisão do nome. Tal nomenclatura é a atual.
} 
língua materna e a língua adquirida" (2008). A partir dessas pesquisas surgiram tantas outras, orientadas pela prof.a Maggio e pela prof.a Mordente, ampliando assim, o olhar sobre as cidades do interior de SP, como Jundiaí e Piracicaba e no interior do Paraná, Cascavel. Desse modo, minha pesquisa iniciou com o projeto Relembrar: reunir a memória e a história - oral e escrita - dos italianos de São Paulo do Programa "Aprender com Cultura e Extensão" da Pró-Reitoria de Cultura e Extensão Universitária da Universidade de São Paulo e foi proposto visando, por um lado, à organização de conteúdos já existentes acerca da vida dos italianos e de seus descendentes no Brasil e, por outro lado, à coleta de novos testemunhos orais, obtidos por meio de entrevistas, e de material escrito pertencente a esses imigrantes italianos e a seus descendentes, através do trabalho prático dos monitores e sob a coordenação das docentes responsáveis, Giliola Maggio e Elisabetta Santoro. O objetivo, naquele momento, era mapear e investigar como se deu a vinda de imigrantes italianos e, sobretudo, qual foi a repercussão desse fenômeno na vida dos protagonistas.

A observação das entrevistas coletadas ao longo de três anos do projeto fez surgir indagações sobre os traços que poderiam levar a refletir sobre a identidade dos descendentes dos imigrantes italianos, a partir dos testemunhos e das narrativas ${ }^{2}$ dos entrevistados. Percebemos que as identidades se manifestam de diferentes formas, às vezes instáveis, inacabadas e contraditórias, de modo que os entrevistados pareciam ter, na verdade, várias identidades, que não podem ser consideradas fixas nem permanentes, ou seja, sofrem alterações de acordo com tempo e de processos inconscientes do sujeito, é algo que sempre está em movimento e em formação.

O corpus, constituído pelas entrevistas realizadas no projeto, seria assim a base para o estudo das falas dos italianos e de seus descendentes, que falaram da história de suas famílias e de suas reflexões sobre o que significa "ser italiano no Brasil". Estabeleceu-se como objetivo desse primeiro momento da pesquisa verificar quais características da identidade dos entrevistados revelavam as suas narrativas.

Após os estudos realizados na Iniciação Científica orientada pela Profa. Dra. Elisabetta Santoro, foi possível observar a construção de traços identitários do falante. Os entrevistados, que inicialmente relatam as histórias de família, tornam-se

\footnotetext{
${ }^{2}$ Na história oral, trabalhamos com gêneros narrativos (MEYHY \& SEAWRIGHT, 2020).
} 
personagens das histórias e criam ou reproduzem em suas falas uma identidade italiana para si.

Assim, foi possível notar como a fala traz diversas vozes inscritas e como as manifestações podem ser explícitas ou implícitas. Foi possível concluir que não existem falas neutras e, com a concepção de identidade do sujeito pós-moderno, segundo Stuart Hall (2019), foi possível compreender porque há dificuldade em definir uma única identidade, já que as pessoas sempre terão identidades múltiplas ${ }^{3}$.

A presente pesquisa pretende dar continuidade ao trabalho já iniciado, aprofundando a análise das entrevistas que compõem o corpus citado, procurando demonstrar como os descendentes estão diretamente ligados à identidade italiana por meio da narrativa utilizada nas entrevistas.

O objetivo geral é analisar as características e a manifestação da identidade dos descendentes de italianos entrevistados. Portanto, a pergunta de pesquisa é: Como se constrói a memória e a identidade dos descendentes de italianos, como elas se manifestam em suas falas? Dessa forma, para responder a essa pergunta, nós colocamos como objetivos específicos a subdivisão de suas falas a partir das categorias como "cozinha", "língua italiana" e "família", procurando identificar recorrências que nos levem a criar uma hipótese sobre a construção de suas identidades, a partir de suas narrativas.

A seguir, faremos uma síntese de como será estruturado o presente trabalho.

A dissertação é subdividida em três capítulos e os abordaremos da seguinte forma: no primeiro capítulo, apresentaremos o panorama da imigração italiana no Brasil e seus reflexos. O enfoque será dado ao estado de São Paulo, que foi o que mais recebeu imigrantes italianos, além de estudarmos os meios de comunicação que existiam para os italianos, já que eles eram grande parte da sociedade paulista e a relação dos imigrantes com a língua italiana.

No segundo capítulo, abordaremos o perfil dos entrevistados, os instrumentos utilizados na coleta das entrevistas, metodologia de História Oral utilizada para gravar as entrevistas e o processo de transcrição.

No terceiro capítulo, apresentaremos o referencial teórico e análise que utilizamos na pesquisa sobre como a língua, a partir da análise das categorias já citadas, 'cozinha', 'língua italiana' e 'família', se manifesta para construir a identidade

\footnotetext{
${ }^{3}$ Aprofundaremos o conceito no Capítulo 3 desta dissertação.
} 
e a memória dos descendentes de italianos. Dessa forma, refletir sobre quais são as concepções de identidade que foram estabelecidas ao longo do tempo, como a memória contribui na construção da identidade e como a identidade pode se manifestar através da língua. Dessa forma, analisaremos os dados das entrevistas de acordo com a teoria que nos serviu de orientação, verificaremos características individuais de cada entrevistado e faremos uma comparação com o panorama geral de todas as entrevistas. Verificaremos as palavras e os trechos que estão ligados à 'cozinha', à 'língua italiana' e à 'família' dos entrevistados e, a partir das recorrências, como se manifesta a identidade italiana.

Para finalizar, faremos nossas considerações finais sobre a análise feita, a fim de demonstrar como se manifesta e se constroem identidade e memória, a partir do uso de palavras recorrentes em suas falas. 


\section{UM BREVE OLHAR SOBRE A IMIGRAÇÃO ITALIANA}

O presente capítulo tem como objetivo situar o Brasil diante da imigração italiana e seu efeito no país. Para isso, nos basearemos nos estudos de Franco Cenni, Angelo Trento, Herbert S. Klein e Oswaldo Truzzi sobre os movimentos migratórios dos italianos na América. Em seguida, focaremos o caso do Estado de São Paulo, que teve o maior fluxo migratório de italianos no Estado.

\subsection{OS ITALIANOS NO BRASIL}

Os historiadores sempre registraram a presença de italianos no Brasil, envolvidos em expedições ou em exílios.

Segundo Trento, a emigração italiana no Brasil ganhou força ao final dos anos 70, quando o país sul-americano chamava atenção pela sua baixa densidade demográfica. Em algumas partes do país, o governo tentava atrair imigrantes e houve tentativas de colonização em algumas províncias, mas não deram certo. Outros fatores que contribuíram com os movimentos migratórios foram o abolicionismo e a evolução da economia. Assim, o café, a partir dos anos 40, começou a substituir o açúcar no cenário da exportação, outro fato que estimulou a emigração italiana para o Brasil, pela necessidade de mão de obra para a agricultura. (TRENTO, 1989, p.19)

Mesmo com a dificuldade em censos demográficos, estima-se que entre 1880 e 1924, entraram mais de 3.600 .000 emigrantes no Brasil, e $38 \%$ eram italianos. (TRENTO, 1989, p.18). No período de 1880-1904 o percentual é de $57,4 \%$.

Os imigrantes ao chegarem ao Brasil, trabalhavam em péssimas condições, as relações sociais eram precárias, além do fazendeiro poder interpretar de forma subjetiva o que tinha sido estabelecido em contrato, com alterações dos livros contábeis e a "má fé dos proprietários", a falta de liberdade dos trabalhadores também foi uma condição de exploração por parte dos fazendeiros. (TRENTO, 1989, p.21)

As condições de trabalho nas lavouras de café, segundo Trento, eram convenientes em alguns casos, pois para cada família era dado um determinado número de pés de café para serem cultivados em troca de um salário fixo, eles também recebiam uma compensação salarial de acordo com a quantidade de café 
colhido e limpo, além do direito de cultivar a agricultura de subsistência em pequenos pastos. Em 1890 a Lei Glicério regulamentou toda a situação dos imigrantes no Brasil, o que evitou muitos golpes e gerou mais segurança. Porém, ainda com as péssimas condições de trabalho, o governo italiano, em 1902, se opôs aos subsídios oferecidos pelo Brasil, o que, segundo Klein, fez cair o número de novos imigrantes italianos. (KLEIN, 1989, p.96).

Trento, que também apresenta esse fato em seu estudo, afirma sobre a oposição italiana sobre a emigração: "medidas meramente restritivas e não de intervenções orgânicas destinadas a garantir um mínimo de proteção para quem vivia e trabalhava no país latino-americano." (TRENTO,1989, p.34)

Os italianos foram recebidos por diversos lugares ao redor do país, mas o foco principal da imigração foi o Estado de São Paulo, devido ao desenvolvimento do café. Eram recebidos pela Hospedaria dos Imigrantes, onde ficavam hospedados por alguns dias até serem encaminhados às fazendas. O percurso da Itália até o Brasil era feito por navio e durava cerca de 40 dias. Após a chegada no porto de Santos, pegavam o trem com destino à hospedaria, localizada na Mooca, ficavam lá por alguns dias e depois seguiam viagem para as fazendas onde iriam começar uma nova vida.

Os italianos avançaram rapidamente no cenário do café no Brasil, assumindo rapidamente o nível de proprietário:

O mesmo padrão de ingresso rápido na classe de proprietários de terras se
deu com os imigrantes italianos que chegaram ao Brasil. Apesar de não haver
dúvidas de que os fazendeiros de café exploravam os trabalhadores
subsidiados e que muitas famílias tiveram experiências negativas durante os
seus anos de trabalho como colonos nas fazendas de café, também não há
dúvidas de que um número significativo de colonos conseguiu poupar
dinheiro e deixar a condição de não-proprietários de terras. (KLEIN, 1989,
p.104).

Outras ondas de imigração italiana foram intensas após o período da abolição, que são justificadas pelas duas grandes guerras que ocorreram entre 1914 a 1918 e depois em 1939 a 1945.

Os imigrantes italianos vieram para as regiões mais avançadas e dinâmicas país. No Brasil eles se se estabeleceram principalmente nos estados centrais e meridionais de crescimento mais acelerado, mas antes de tudo em São Paulo. Em 1920 aproximadamente 70\% dos italianos residiam neste estado e representavam $9 \%$ da sua população total. (KLEIN, 1989, p.101) 
Os estados que mais ricos como São Paulo, Rio Grande do Sul e Minas Gerais eram os que mais tinham imigrantes como proprietários de terra. A estatística é a seguinte:

\begin{abstract}
Um terço dos proprietários de terras italianos viviam em São Paulo e apesar de constituírem $9 \%$ da população total do estado, representavam $15 \%$ dos proprietários de terras e detinham $9 \%$ do valor total das propriedades rurais. No Rio Grande do Sul, zona das colônias agrícolas especiais, eles respondiam por $5 \%$ do valor total das propriedades rurais e constituíam $11 \%$ dos proprietários de terras, apesar de serem apenas $2 \%$ da população do estado. Até mesmo em Minas Gerais, o segundo estado mais rico em termos de valor da propriedade rural e um dos estados menos influenciados pela imigração estrangeira, os italianos tiveram uma presença significativa. Representavam mais da metade de todos os proprietários de fazendas nascidos no exterior e, apesar de constituírem menos de 1\% da população total, respondiam por $1,8 \%$ do valor dos imóveis rurais. (KLEIN, 1989, p.106)
\end{abstract}

Dessa maneira, os italianos auxiliaram no desenvolvimento do país, tanto na agricultura como na indústria, áreas que tiveram grande crescimento nos estados mais ricos. Os dados de pesquisas da época evidenciam o significativo crescimento econômico do país e dos próprios italianos, de forma geral.

Truzzi fala sobre o desenvolvimento do italiano no trabalho, como empresário ou como empregado:

Tanto no comércio quanto na indústria, foi exatamente o imigrante o protagonista principal em qualquer dessas atividades, seja diretamente como empresário, seja como empregado. Tome-se o exemplo da indústria francana, na qual o papel do imigrante - italiano, em particular - foi notável. Quando se consideram as 65 fábricas de calçados registradas entre 1900 e 1945, período que poderíamos classificar como de gênese e princípio da afirmação das bases do empresário do calçado, constata-se de que 36 delas (55\%) tinham proprietários ou sócios de origem italiana. (TRUZZI, 2016, p.68)

\title{
2.2 OS ITALIANOS EM SÃO PAULO
}

Conforme evidenciado anteriormente, o estado de São Paulo foi o que mais recebeu imigrantes italianos, devido ao grande número de fazendas de café que havia nesse local. O estado recebeu não só os italianos, mas muitos estrangeiros, de forma geral, os dados demográficos indicam que: "dos 4.100.000 estrangeiros entrados no Brasil entre 1886 e 1934, 56\% foram absorvidos por essa região." (TRENTO, 1989, p.107)

Em São Paulo foram implantadas colônias italianas como na região sul, mas o que deu força para a imigração foi o desenvolvimento do plantio de café. Inicialmente, 
os estrangeiros vieram para as fazendas de café, com sua maior parte localizada no Oeste Paulista, e depois ajudaram no ramo industrial que passou a se desenvolver em todo o estado. Segundo Truzzi:

A própria economia cafeeira estimulava o desenvolvimento de várias
atividades comerciais, artesanais e, depois, industriais abraçadas por
italianos. Em todo o interior paulista, encontraremos pelo menos quatro
diferentes tipos de empresas que em boa medida floresceram à sombra dos
estímulos da economia cafeeira: os engenhos e atividades de beneficiamento
do café e de outros cereais; as oficinas de manutenção que as estradas de
ferro requeriam (serralherias, fundições, forjarias, serrarias etc.), a indústria
têxtil nascente (estimulada em boa parte pela demanda de sacaria para o
café) e a indústria produtora de artigos para o consumo popular (alimentos,
bebidas, vestuários, móveis etc.). Isso sem falar no comércio propriamente
dito, inclusive aquele de importação de produtos italianos, cujas firmas não
raro abrigaram também atividades bancárias, remessas de valores e venda
de passagens à ltália. (TRUZZI, 2016, p.62)

Para o interior do estado foram $90 \%$ dos emigrantes que saíram da hospedaria de São Paulo entre 1893 e 1910, segundo Trento, O Oeste Paulista conhecerá os maiores progressos pela melhor qualidade da terra, pelas técnicas mais modernas, pela introdução da mão-de-obra livre e pela generalização do consumo de café a nível mundial, especialmente nos Estados Unidos. (TRENTO, 1989, p.109)

Nessa perspectiva, o estado oferecia subsídio para os italianos que fossem para as lavouras. Segundo Trento, em 1884 o governo criou uma lei "que previa o transporte gratuito para as famílias que se instalassem nas fazendas ou nos núcleos coloniais." (TRENTO, 1989, p.23)

Importante ressaltar que o número de italianos cresceu gradativamente em São Paulo e por mais que seja difícil ter uma estatística exata, Franco Cenni nos dá um panorama do fenômeno paulista:

Em 1887 o incremento da imigração italiana é extraordinário, subindo a mais
de 27 mil, para atingir 80749 no ano seguinte. Nos dois anos subsequentes
a imigração decresce, reduzindo-se respectivamente a 19025 e 20991 . Em
1891 sobe a 84486 , seguindo-se três anos de menor movimento, até que em
1895 a imigração italiana alcançou o apogeu, registrando-se a entrada de 106
526 pessoas. Em 1896 a corrente imigratória italiana, por si só, representava
quase o dobro das demais, e dois anos depois, em 1898, mais da metade da
imigração é ainda de procedência italiana, verificando-se o mesmo nos dois
anos que se seguem. Em 1901 os italianos representam quase dois terços
do total de imigrantes e nos dois anos seguintes mais da metade. Somente
em 1905 seu número é superado pelos espanhóis, retomando em 1907 o
primeiro lugar, para serem superados mais tarde por portugueses e
espanhóis. (CENNI, 2011, p. 219) São Paulo cresceu rapidamente no cenário de exportação de café, pois os fazendeiros conseguiam investiam em outros ramos, como bancos e ferrovias, o que 
desenvolveu ainda mais a economia local e aumentou a rentabilidade das lavouras, já que com ferrovias se gastava menos com transporte para a logística do produto.

O fato de o governo paulista subsidiar a imigração italiana para o Estado, fez com que o número de imigrantes crescesse significativamente:

A imigração subvencionada constituiu, em São Paulo, 89\% da imigração total entre 1891 e 1895. É óbvio que, para financiá-la, foram empregadas somas enormes, tanto pelo governo central como pelos estados; mas elas foram amplamente cobertas pelos índices de exportação do café, cujo aumento contínuo foi tornado possível pelo trabalho europeu. (TRENTO, 1989, p. 28)

Após a saída de alguns imigrantes para a área urbana do estado, a evolução do campo industrial também cresceu de modo considerável, e claro que recebeu a ajuda dos italianos:

Em 1919 o estado de São Paulo abrigava 32\% das indústrias brasileiras, taxa esta que aumentou de 15\% em 1909, e esta concentração só aumentaria nos anos seguintes. Os proprietários de fábricas italianos foram um elemento importante neste crescimento. Em 1920 os italianos possuíam 1.500 pequenas empresas industriais (aquelas com apenas um proprietário), ou $49 \%$ do total do estado de São Paulo. Obviamente, eles não tiveram neste estágio inicial um desempenho tão bom na grande indústria. Uma pesquisa de grandes empresas em 1914, no Rio de Janeiro e em São Paulo, mostrou que os italianos detinham apenas $16 \%$ do total. Algumas dessas empresas, como a Matarazzo, em que trabalhavam 10.000 trabalhadores em 1922, estavam entre os principais agentes do setor industrial brasileiro. (KLEIN, 1989, p.107)

No cenário de desenvolvimento da área urbana, surgem os famosos bairros da capital que foram habitados por grande quantidade de imigrantes italianos, como Brás e Bixiga. Franco Cenni dedica algumas páginas do seu livro para falar sobre esses bairros:

\footnotetext{
Enquanto os imigrantes italianos provenientes da Calábria preferiam morar no bairro do Bexiga (atual Bela Vista) e os vênetos no Bom Retiro (onde até hoje existe uma rua dos Italianos, embora por aqueles lados já não haja italianos há muito tempo), os napolitanos se fixaram quase todos no Brás, 0 bairro italiano por excelência. (CENNI, 2011, p.288)
}

Com a grande quantidade de imigrantes italianos, a cidade de São Paulo, em particular, assumiu um caráter italiano, segundo Trento, que refletia na comida, no estilo das casas e nos anúncios, que eram escritos em português e italiano. $O$ rápido crescimento demográfico da cidade também era devido aos imigrados. Ainda segundo Trento: "em 1920, quase 2/3 dos habitantes eram estrangeiros ou descendentes, e os italianos representavam mais da metade da população adulta de sexo masculino." (TRENTO, 1989, p. 123-124). 


\subsection{A LÍNGUA ITALIANA EM SÃO PAULO E OS MEIOS DE COMUNICAÇÃO}

A significativa presença de imigrantes italianos no Estado de São, refletiu em diversos aspectos, de ordem política, sociocultural ${ }^{4}$, mas também na questão da língua italiana. Sobre a questão da alfabetização dos imigrantes, Klein destaca:

Os migrantes que se dirigiam à Argentina e ao Brasil aparentemente eram mais alfabetizados do que os que foram para os Estados Unidos (ainda que os dados não sejam exatamente comparáveis), mas a maioria dos que migraram para esses três países americanos era alfabetizada, da mesma forma que a maior parte da população italiana, de acordo com o censo de 1901. Os imigrantes que foram para a América, contudo, eram ligeiramente mais alfabetizados enquanto grupo do que a totalidade da população italiana (...). O mesmo é válido para a amostra de São Paulo, que apresentava apenas $32 \%$ de analfabetos entre os migrantes italianos de 7 anos de idade ou mais que chegaram ao porto de Santos entre 1908 e 1936 (...). (KLEIN, 1989, p.99)

O estado contava com alguns recursos que auxiliavam a promover a língua italiana, principalmente na cidade de São Paulo, como a presença de escolas e jornais italianos, elementos de grande importância para os imigrantes. Segundo Klein, no Brasil aproximadamente 23 mil crianças frequentavam as escolas italianas em 1913.

Franco Cenni destaca a quantidade de italianos analfabetos que vieram para o Estado de São Paulo entre 1908 a 1927, que era de aproximadamente $28,72 \%$. Sobre o número de escolas, o autor explica que em 1906 havia 50 escolas na cidade de São Paulo e 36 no interior do Estado. (CENNI, 2011, p. 321). Surgiram diversas escolas italianas, e algumas se tornaram escolas de grande destaque na cidade, como o Colégio Dante Alighieri.

O que ajuda a compreender a questão da língua italiana no Brasil é a questão dos dialetos. Os imigrantes, em sua maioria, falavam os respectivos dialetos de sua região de proveniência e não a norma culta da língua italiana. Concernente ao assunto, Cenni destaca um estudioso que discorre sobre a questão do dialeto entre os imigrantes:

No início da grande imigração, quando os italianos constituíam altas porcentagens da população, a maioria deles se exprimia nos respectivos dialetos, tornando difícil, em certos casos, a difusão, entre eles, da própria língua italiana. A este propósito, é interessante lembrar que o deputado Enrico Ferri (profundo estudioso dos problemas da emigração italiana na América do Sul, onde tinha verificado várias vezes in loco a situação) afirmava na Câmera dos Deputados italiana em 1909: [...] Os italianos da América do Sul aprendem e falam mais facilmente o espanhol e $p$ português

\footnotetext{
${ }^{4}$ Não nos deteremos sobre essas questões ao longo de nossa dissertação.
} 
do que o italiano. Por quê? Porque os italianos que para lá emigram falam seus dialetos. Por exemplo: um piemontês, jovem ou adulto, que chega no Brasil tem quase o mesmo trabalho para aprender o italiano ou o português, e então procura aprender o português, antes que o italiano. (CENNI, 2011, p.323)

Cenni fala sobre o período em que o ensino da língua italiana foi obrigatório no estado de São Paulo, segundo a proposta de Samuel Malfatti de junho de 1893, projeto que durou até agosto do mesmo ano. A proposta era a seguinte:

\begin{abstract}
Dep. Malfatti: "Acho que deve ser incluído o ensino da língua italiana, cuja necessidade, além de ser justificada pelo grande número de italianos que povoa nosso estado e pelas importantes relações que mantemos com a pátria italiana, é ainda comprovado pelo fato que a literatura italiana nos fornece um grande subsídio, do qual aproveitam os estudantes de nossa Faculdade de Direito e de outros Institutos de instrução. Acho portanto justificada a emenda que tenho a honra de apresentar e espero que a Câmara a tomará em consideração" (aprovações). É lido, apoiado e posto em discussão o projeto com a seguinte emenda do deputado Malfatti: Artigo 11, junte-se: o ensino da língua italiana. Encerrada a discussão, é aprovado o projeto com as emendas apresentadas. (CENNI, 2011, p. 326)
\end{abstract}

Os italianos aprendiam o português para facilitar a comunicação nas negociações de mercado. Por isso, muitas vezes, insistiam para os filhos também aprenderem a língua utilizada no Brasil, para facilitar as relações com os brasileiros, para terem maiores oportunidades de trabalho, além deles priorizarem o trabalho em relação à educação, pois o sustento da família era o ponto principal.

Segundo Trento, as associações italianas em alguns estados do Brasil contribuíram para a divulgação da língua materna dos italianos, além de serem lugares em que os italianos podiam se reunir e se ajudar. As associações também eram úteis para socorrer os imigrantes em caso de acidentes de trabalho, por exemplo.

Dentre as associações que foram importantes para a difusão da cultura e instrução italiana, podemos citar a "Associação de inspiração laica Dante Alighieri", a "Associação Nacional para socorrer imigrantes e missionários italianos pelo mundo" e a "Italica Gens". (BARAUSSE \& LUCHESE, 2017).

Truzzi ressalta, ainda, a importância das associações italianas na manutenção da italianidade e como eram os incentivos à prática associativa:

A princípio, os maiores incentivos à prática associativa provinham da absoluta carência de instituições e ausência de políticas sociais que pudessem amparar minimamente os imigrantes em termos econômicos, de saúde e educação para os filhos - de onde advém o caráter inicialmente mutualista 
da maioria das associações -, a par do desejo de reconhecimento do grupo na nova sociedade. (TRUZZI, 2016, p.87)

Uma questão fundamental é a presença da imprensa italiana, que, Segundo Trento, foi fundada por imigrantes que dedicavam suas publicações aos acontecimentos italianos de forma simples através de boletins, jornais religiosos, entre outros. É interessante observar o trecho em que fala sobre o crescimento da imprensa italiana com uma maioria de imigrantes analfabetos:

\begin{abstract}
Se as associações eram muitas e as escolas ainda mais, o verdadeiro elemento de surpresa é representado pelo incrível número de jornais e revistas em língua italiana publicados no Brasil entre 1880 e 1940 e, sobretudo, entre 1885 e 1920 . Elemento de surpresa porque a variedade de títulos presentes pressupunha um público que, na realidade, não existia. De fato, apesar do elevado número de italianos residentes no Brasil, em sua grande maioria tratava-se de analfabetos ou semi-analfabetos, e, de qualquer modo, de pessoas cujo horário de trabalho ou cujos compromissos eram tão pesados que não Ihes permitiam qualquer tipo de aproximação com os jornais, tanto em língua italiana quanto em português. Apesar disso, em 1907, só nas bancas de São Paulo encontravam-se cinco diários - Fanfulla, La Tribuna Italiana, II Secolo, Avanti! e Corriere d'Italia - e uma dezena de semanários. (TRENTO, 1989, p.184)
\end{abstract}

A dificuldade em aprender o italiano padrão e a urgência em utilizar a língua portuguesa refletiu em muitas histórias de famílias, que diziam que os familiares que sabiam o italiano evitavam falar o idioma com os filhos e netos, para que se dedicassem ao aprendizado da língua portuguesa. Em algumas famílias se falavam o dialeto, mas como os italianos precisavam se estabelecer rapidamente no Brasil, por questões de sobrevivência, o português ganhava vantagem.

Outro fato importante para o estudo da língua italiana no Brasil foi o período Vargas (1930-19450), que durante a campanha de nacionalização os idiomas italiano, japonês e alemão foram proibidos de serem utilizados em público, porque os países Itália, Japão e Alemanha pertenciam ao Eixo durante a Segunda Guerra Mundial, e eram considerados inimigos do Brasil. Essa proibição fez com que a língua italiana se perdesse ainda mais entre os imigrantes.

Um trabalho que foi desenvolvido sobre a imprensa italiana em São Paulo é o da pesquisadora Eugenia Vezzelli com a tese "A construção do ethos discursivo na imprensa em língua italiana em São Paulo: o caso de La Difesa". A pesquisadora analisa editoriais do jornal La Difesa que é considerado um jornal antifascista italiano em São Paulo, diferente do Fanfulla, que se alinhava ao Mussolini, é um trabalho de 
perspectiva linguística que contribui para o desenvolvimento de novas pesquisas sobre o processo migratório italiano.

No próximo capítulo abordaremos a metodologia da pesquisa. 


\section{O PERCURSO DA PESQUISA}

A pesquisa seguiu uma linha qualitativa, com o objetivo de compreender determinados fenômenos através da coleta de entrevistas e fundamentada na teoria de Meihy e Ribeiro (2011) e Meihy (1996) sobre a História Oral.

Neste capítulo de metodologia, abordarei os seguintes tópicos: metodologia adotada; perfil dos entrevistados; roteiro e instrumentos utilizados na coleta dos dados; procedimentos adotados para análise das entrevistas.

\subsection{METODOLOGIA ADOTADA}

A História Oral, segundo Meihy e Ribeiro, é composta por algumas etapas, são elas, a necessidade de um projeto, a definição do grupo que será entrevistado e a prática de entrevistas. Os autores definem entrevista em História Oral como "[...] encontros planejados, gravados por diferentes mídias, decorrentes de projeto, exercitado de maneira dialógica, ou seja, com perguntas/estímulos e respostas." (MEIHY e RIBEIRO, 2011, p.12)

A técnica citada é um recurso que passou a ser muito utilizado com o avanço da tecnologia, pois é uma forma de manter a história viva, Meihy, em seus manuais, explica que esse tipo de ferramenta considera não só a história de personagens históricos, mas de cidadãos comuns. É uma forma de registrar a história para as gerações futuras. Para Meihy:

Resultado dos avanços da tecnologia, principalmente de meios eletrônicos como o gravador, o vídeo e o computador, a História Oral se apresenta como forma de captação de experiências de pessoas dispostas a falar sobre aspectos de sua vida mantendo um compromisso com o contexto social. (MEIHY, 1996, p.13)

Havia um projeto inicial antes de gravar as entrevistas, nesse projeto foram definidos o roteiro e o grupo de pessoas que seriam entrevistadas. O projeto é a base que norteia as entrevistas. Os autores explicam sobre o projeto:

[...] o plano capaz de articular argumentos operacionais de ações desdobradas de planejamentos de pesquisas prévias sobre algum grupo social que tem a algo dizer. Pode-se afirmar que sem projeto não há História Oral. (MEIHY e RIBEIRO, 2011, p.13) 
Após a definição do projeto, Meihy destaca a sequência e as etapas que devem ser seguidas na organização da História Oral após a elaboração do projeto:

[...] continuam com a definição de um grupo de pessoas (ou colônia) a serem
entrevistadas, com o planejamento da condução das gravações, com a
transcrição, com a conferência do depoimento, com a autorização para o uso,
arquivamento e, sempre que possível, com a publicação dos resultados que
devem, em primeiro lugar, voltar ao grupo que gerou as entrevistas. (MEIHY,
1996, p.15).

Os encontros eram agendados, os entrevistados recebiam as autorizações para o uso da entrevista e o entrevistador fazia perguntas e estímulos para os participantes. É importante diferenciar as definições de estímulo e respostas: "Pergunta é diferente de estímulo. Nas perguntas, busca-se ter respostas objetivas, diretas, e nos estímulos procura-se a lógica e a construção de argumento." (MEIHY e RIBEIRO, 2011, p.12)

Na teoria, há uma diferenciação entre "fins e meio", ou seja, se a gravação é apenas para compor um banco de dados, ou seja, será um "fim", se utilizada para análise, a entrevista será o "meio". Para este trabalho, as entrevistas foram utilizadas como "meio", pois são a base de análise. A partir de sua transcrição, surgiram indagações a respeito da fala de identidade. Sobre esse "duplo objetivo":

Normalmente a documentação resultante da gravação de entrevistas é arquivada com duplo objetivo: jurídico e de acervo, para que eventualmente, no futuro, sejam feitos estudos sobre a história da instituição. Assim, caso as entrevistas gravadas para bancos de histórias sejam aproveitadas mais tarde por outros pesquisadores, a condição de fim para a situação de banco de histórias permanece inalterada, mas se transforma em meio para os pesquisadores que venham fazer qualquer uso delas. (MEIHY e RIBEIRO, 2011, p.14)

Meihy e Ribeiro (2011, p. 16) explicam que existem três tipos de História Oral: instrumental, plena e híbrida. Na História Oral instrumental o objetivo é apenas gravar as entrevistas, sem analisá-las. A História Oral plena, considerada a mais completa pelo autor, envolve a gravação e a análise das entrevistas. E por fim, a História Oral híbrida deseja analisar a entrevista junto com outros documentos, com uma dimensão analítica. Adotamos para o presente trabalho, a metodologia da História Oral plena, pois envolve a gravação, transcrição e análise.

Ademais, em todos os projetos de História Oral, segundo os autores, deverá haver a elaboração do projeto; a captação, tratamento e guarda do material; e a destinação do produto. (MEIHY e RIBEIRO, 2011, p.17) 
No terceiro tópico é importante ressaltar que os autores consideram fundamental o retorno do trabalho final, em primeiro lugar, para os entrevistados e, quando for o caso, para a comunidade envolvida no projeto. Ressaltam, ainda, a importância de ter um retorno para a sociedade, seja através de publicações em sites, catálogos ou dissertações e teses. (MEIHY e RIBEIRO, 2011, p.13)

\subsection{PERFIL DOS PARTICIPANTES}

Foram entrevistadas 25 pessoas ao longo de todo o projeto. São homens e mulheres com alguma ascendência italiana. Filhos, netos e bisnetos puderam contar a história de seus familiares em entrevistas.

A maior parte dos entrevistados é composta por professores da USP, pois trabalhavam no local onde era realizada a entrevista, o que facilitava o processo, já que a maior dificuldade era trazer os descendentes de italianos para a universidade, principalmente pela sua localização afastada. Algumas pessoas se dispuseram a contar a história da família, mas quando eram convidadas a irem até a USP, os colaboradores desistiam.

Durante os primeiros dois anos do projeto, o trabalho de coleta, tratamento e armazenamento das entrevistas foram tarefas de dois monitores bolsistas (estudantes de graduação) do "Programa Aprender com Cultura e Extensão" da Universidade de São Paulo. No terceiro ano do projeto, fui monitora e pude assumir, junto com as professoras coordenadoras, a função de cuidar das entrevistas já gravadas e coletar novas entrevistas. Todos os três monitores auxiliaram nas gravações e em alguns momentos puderam exercer o papel de entrevistadores. Todas as entrevistas estão armazenadas em um HD externo e em uma nuvem (Google Drive).

As professoras coordenadoras do projeto, no referido período, foram Giliola Maggio e Elisabetta Santoro, e fazem parte da Área de Língua e Literatura Italianas, são pesquisadoras junto ao Programa em Língua, Literatura e Cultura Italianas do Departamento de Letras Modernas da Faculdade de Filosofia, Letras e Ciências Humanas da Universidade de São Paulo. As duas professoras, em algum momento, também tiveram papel de entrevistadoras durante as gravações. 
Quanto à presente pesquisa, das 25 entrevistas, escolhi 10 para fazerem parte do meu corpus de análise. Escolhi todas as entrevistas que foram coletadas por mim e outras que me chamaram a atenção por sua narrativa, pois durante o processo de transcrição, foi possível identificar em algumas entrevistas a presença de frases e palavras italianas pertinentes para a pesquisa. $O$ fato de ter contato com algumas entrevistas durante a minha Iniciação Científica contribuiu também para a escolha, já que ouvi todas durante a pesquisa.

Nesse sentido, segue abaixo o quadro com informações dos entrevistados:

Quadro 1 - Perfil dos entrevistados

\begin{tabular}{|l|l|l|l|l|}
\hline Entrevista & Sexo & $\begin{array}{l}\text { Parentesco com o } \\
\text { italiano }\end{array}$ & Fala italiano & Profissão \\
\hline 01 & Feminino & Neta & Não & Professora \\
\hline 02 & Feminino & Nacionalidade & Sim & Professora \\
\hline 03 & Feminino & Bisneta & Sim & Professora \\
\hline 04 & Masculino & Neto & Não & $\begin{array}{l}\text { Diretor de } \\
\text { negócios }\end{array}$ \\
\hline 05 & Masculino & Neto & Não & Professor \\
\hline 06 & Masculino & Neto & Não & Professor \\
\hline 07 & Masculino & Neto & Sim & Professor \\
\hline 08 & Feminino & Neta & Não & Professora \\
\hline 09 & Feminino & Filha & Sim & Professora \\
\hline 10 & Masculino & Neto & Sim & Engenheiro \\
\hline
\end{tabular}

Fonte: autora

Os nomes e sobrenomes dos entrevistados e dos familiares citados nas entrevistas foram omitidos para preservar a identidade dos entrevistados e das famílias. Todas as entrevistas foram numeradas e seguem a numeração de 0 a 10.

\subsection{ROTEIRO E INSTRUMENTOS UTILIZADOS}

Para a gravação das entrevistas foi utilizado o estúdio do Laboratório de Apoio à Pesquisa e ao Ensino de Letras (LAPEL) da Faculdade de Filosofia, Letras e Ciências Humanas da Universidade de São Paulo. A câmera utilizada foi a Sony, modelo EX-PRO com microfone embutido. O estúdio utilizado conta com uma mesa 
retangular com duas cadeiras, uma para o entrevistado e outra para o entrevistador. As cadeiras ficaram posicionadas uma ao lado da outra durante as gravações.

O roteiro de perguntas utilizado conta com 6 perguntas, a última pergunta (sobre o jornal) foi adicionada nas últimas gravações:

(1) O que você sabe de como a sua família veio para o Brasil?;

(2) Vieram diretamente para São Paulo ou ficaram em outras cidades antes?;

(3) Você lembra de alguma história sobre a Itália que se conta(va) na sua casa?;

(4) E que língua se fala(va) na sua casa? Alguém ainda fala italiano? Você já ouviu alguém falando italiano?;

(5) E como você acha que foi ser italiano em SP? O que você acha que se pensa dos italianos no Brasil e, em especial, em SP?;

(6) Você lembra se era lido algum jornal em italiano na sua casa?

As cinco primeiras perguntas foram criadas no primeiro ano do "Programa Aprender com Cultura e Extensão", com os monitores e as professoras coordenadoras do referido projeto. No terceiro ano, as coordenadoras decidiram incluir a sexta e última questão.

Meihy em seu manual explica a importância sobre as perguntas em entrevistas de História Oral: "Nas entrevistas de História Oral de vida, as perguntas devem ser amplas, sempre colocadas em grandes blocos, de forma indicativa dos grandes acontecimentos e na sequência cronológica da trajetória do entrevistado." (MEIHY, 1996, p.35) As perguntas amplas dão fluidez às entrevistas, pois permitem que o colaborador se sinta mais confortável ao contar a história.

Além das perguntas objetivas, as entrevistas também têm incentivos feitos/dados pelo entrevistador, pois em alguns momentos o colaborador respondia de forma rasa a pergunta e os estímulos ajudaram o desenvolvimento e a organização da resposta.

Foi utilizada uma carta convite ${ }^{5}$ para convidar a comunidade a participar e apresentando o projeto, chamando imigrantes italianos e seus descendentes a compartilharem as histórias de família e outros materiais, como documentos.

Outra ferramenta utilizada foi o termo de autorização para o uso da entrevista (em anexo) os participantes assinaram o termo antes de começar o processo de gravação. Todos eles foram informados que se tratava de um projeto da Universidade

\footnotetext{
${ }^{5}$ Anexo I.
} 
de São Paulo e que os dados seriam exclusivamente usados para fins didáticos, de pesquisa e divulgação científica. As entrevistas foram agendadas via e-mail com todos os participantes.

As entrevistas foram transcritas de acordo com o método jeffersoniano 6 de transcrição, os detalhes da transcrição estão em Sacks, Schlegoff \& Jefferson (1974), que é um dos métodos utilizados em estudos de língua falada.

\subsection{PROCEDIMENTO DE ANÁLISE}

A análise das entrevistas foi separada em duas etapas, a primeira etapa consiste em transcrição e a segunda etapa analisa as palavras e trechos que remetem à construção da memória e identidade italiana de cada entrevistado.

Iniciei o processo de transcrição das entrevistas durante a pesquisa de Iniciação Científica, quando seis (06) entrevistas foram transcritas. O primeiro passo para iniciar as transcrições foi assistir as entrevistas para compreender a narrativa do entrevistado, pois esse primeiro momento facilita a transcrição.

As transcrições foram realizadas na ferramenta de editor de texto (Microsoft Word) e foi necessário dividir a tela para o vídeo e para o texto. Cada vídeo de 30 minutos demorou cerca de 3 horas para ser completamente transcrito.

Após a primeira etapa da transcrição foi realizada a marcação temporal das falas, a fim de facilitar a busca de determinados trechos no vídeo através da minutagem.

As marcas de oralidade foram adicionadas após a entrevista já transcrita; assim, fiz uma nova escuta de cada frase e adicionei as marcações. A terceira etapa consistiu na revisão de toda a transcrição e os ajustes finais necessários.

Para esta pesquisa, quatro (04) novas entrevistas foram transcritas para completar o corpus de análise. Durante o longo processo de transcrição foi possível observar a recorrências de temas das categorias que foram escolhidas para a análise.

\footnotetext{
${ }^{6}$ Anexo II.
} 
As etapas de assistir cada entrevista e transcrever foram fundamentais para verificar pontos que poderiam servir de estudo, não só para a presente pesquisa, mas para estudos futuros.

Utilizei a ferramenta de "localizar" do Word para buscar as palavras que julgo fundamentais para a análise, considerando apenas as ocorrências nas falas dos entrevistados. Quanto à tabela com a quantidade de ocorrências de palavras e os gráficos utilizei o Excel.

As categorias de análise são: "cozinha", "língua italiana" e "família". Durante a análise de cada entrevista é possível observar como é construída a memória e manifestada a identidade de cada entrevistada(o) de acordo com a sua narrativa.

No próximo capítulo abordarei o referencial teórico e a análise das entrevistas. 


\section{CONSTRUINDO A IDENTIDADE: MEMÓRIAS DA "COZINHA", DA "LÍNGUA ITALIANA" E DA "FAMÍLIA"}

Neste capítulo, abordamos o ponto de vista dos teóricos que nos orientam. Para isso, iniciamos com os estudos de Identidade, focalizando Zygmunt Bauman (2005), Stuart Hall (2019) e Anna De Fina (2007). Em seguida, passamos à discussão a respeito de memória, com os autores Maurice Halbwachs (2003), Paul Ricouer (2007) e Michael Pollak (1992). Procuraremos, assim, entrelaçar o referencial teórico à análise das palavras recorrentes nas 10 entrevistas e demonstrar como se manifesta e se constroem identidade e memória.

\subsection{IDENTIDADE}

A fim de iniciar a reflexão sobre o conceito de Identidade, apresentaremos a construção e a transformação do conceito ao longo dos anos. Como base teórica, utilizaremos os autores Zygmunt Bauman (2005), Stuart Hall (2019) e Anna De Fina (2007). Mostraremos como aparece a identidade dos sujeitos entrevistados e os trechos das entrevistas que confirmam ou refutam a ideia dos pensadores.

\subsubsection{0 conceito de identidade}

Trabalharemos com o conceito de identidade social, ou seja, corresponde a uma posição no mundo e na sociedade, diretamente ligado ao reconhecimento e ao pertencimento. Sendo assim, podemos encontrar múltiplas identidades em um indivíduo.

O conceito de identidade, segundo o dicionário Aurélio7:

Identidade: 01. Qualidade de idêntico. 02. Conjunto de caracteres próprios e exclusivos de uma pessoa: nome, idade, estado, profissão, sexo, defeitos físicos, impressões digitais, etc. 03. O aspecto coletivo de um conjunto de características pelas quais algo é definitivamente reconhecível, ou conhecido. (Dicionário Aurélio da Língua Portuguesa, 2010)

\footnotetext{
${ }^{7}$ Dicionário Aurélio Online: Dicionário Aurélio da Língua Portuguesa, 2010, 5ạ edição.
} 
Stuart Hall nos traz a evolução da concepção de identidade, que mudou ao longo dos anos. Para o autor, a identidade é um conceito complexo e é difícil atribuir conclusões fechadas ao tema.

Ele adota a ideia de que "as identidades modernas estão sendo "descentradas", isto é, deslocadas ou fragmentadas" (HALL, 2019, p.09). Hall publicou sua obra no início dos anos 90 e a identidade já era pensada como "fragmentada"; já no início dos anos 2000, Bauman nos apresenta a "identidade líquida" em sua obra (BAUMAN, 2005).

Encontramos semelhanças entre os pensamentos de Hall e Bauman, ambos fazem um traçado histórico sobre os estudos de identidade, para eles, as definições de identidade de antigamente não funcionam na atualidade. Hall nos apresenta três concepções de identidade e Bauman apresenta duas divisões, mas o pensamento permanece o mesmo na ideia geral sobre a identidade, alterando-se apenas as nomenclaturas.

As três concepções de identidade que Hall explica em sua obra são: "o sujeito do lluminismo, o sujeito sociológico e o sujeito pós-moderno" (HALL, 2019, p.10). Segundo o autor, o sujeito do lluminismo tinha um núcleo interior, tendia a permanecer "idêntico" a si mesmo ao longo de sua vida. O sujeito sociológico, para Hall, era complexo e refletia o mundo moderno, sua identidade era formada na relação com outras pessoas.

Para Hall, foi o sujeito sociológico que nos trouxe a ideia de que "a identidade é formada na "interação" entre "eu" e a "sociedade". (HALL, 2019, p.11). A nossa identidade, então, é formada quando entramos em contato com o outro e, segundo o autor, há um diálogo entre o mundo exterior e o mundo pessoal:

O fato de que projetamos a "nós mesmos" nessas identidades culturais, ao
mesmo tempo que internalizamos seus significados e valores, tornando-os
"parte de nós", contribui para alinhar nossos sentimentos subjetivos com os
lugares objetivos que ocupamos no mundo social e cultural. A identidade,
então, costura (ou para usar uma metáfora médica, "sutura") o sujeito à
estrutura. Estabiliza tanto os sujeitos quanto os mundos culturais que eles
habitam, tornando ambos reciprocamente mais unificados e predizíveis.
(HALL, 2019, p.11)
-moderno, ainda segundo Hall, é o sujeito que passou pelo sociológico e após viver uma identidade "unificada e estável”, passa a ser composto 
de diversas identidades, que podem ser fragmentadas ou contraditórias. O sujeito pósmoderno "não tem uma identidade fixa, essencial ou permanente." (HALL, 2019, p.11)

Segundo o mesmo autor, a globalização está diretamente relacionada às mudanças que ocorreram com os sujeitos, pois ocorrem mudanças em toda a sociedade de forma mais frequente e rápidas, diferente do que acontecia na sociedade tradicional. Na globalização, não há uma organização central, pois há descentralização por toda parte, portanto, as identidades descentralizadas acompanham uma sociedade descentralizada.

Por este ângulo, a identidade nacional também é uma construção: nascemos com uma nacionalidade, porém, a identidade é construída através da narrativa e pelas representações. Observamos que a identidade nacional, que é constituída pela identidade cultural, também pode apresentar contradições e diferenças. Novamente uma questão atribuída à globalização, graças ao desenvolvimento global as identidades culturais estão fragmentadas, pois os sujeitos têm acesso à pluralidade cultural através de diversas formas como viagens, mídia e sistemas de comunicação.

A globalização também traz a tentativa de uma "homogeneização cultural", como a utilização de uma determinada língua e uma determinada moeda para relações mercadológicas. Nos dias atuais, podemos concluir que a língua inglesa e o dólar são reconhecidos em todo o mundo. Esta é uma característica do processo de "homogeneização cultural". Em contra partida, existe um novo movimento de valorização da identidade local, que apresenta novas identidades.

Hall nos mostra como essas mudanças na sociedade contribuem para a fragmentação do sujeito e, assim, cria uma crise de identidade no indivíduo, a necessidade de se adaptar do sujeito em alguma cultura que o rodeia é fruto da globalização, por isso, as identidades nacionais culturais também ficam deslocadas. Pessoas que tiveram que sair de sua terra natal passam a conviver com novas culturas e passam a negociar a cultura local com as suas próprias anteriores, algo comum em imigrantes e refugiados. Ainda sobre esse tema, Hall nos apresenta o conceito de "tradução":

Esse conceito descreve aquelas formações de identidade que atravessam e intersectam as fronteiras nacionais, compostas por pessoas que foram dispersadas para sempre de sua terra natal. Essas pessoas retêm fortes vínculos com seus lugares de origem e suas tradições, mas sem a ilusão de um retorno ao passado. Elas são obrigadas a negociar com as novas culturas 
em que vivem, sem simplesmente serem assimiladas por elas e sem perder completamente suas identidades. Elas carregam os traços das culturas, das tradições, das linguagens e das histórias particulares pelas quais foram marcadas. A diferença é que elas não são e nunca serão unificadas no velho sentido, porque elas são, irrevogavelmente, o produto de várias histórias e culturas interconectadas, pertencem a uma e, ao mesmo tempo, a várias "casas" (e não a uma "casa" particular). (HALL, 2019, p.52) ${ }^{8}$

Esse conceito, discutido no último capítulo da obra de Hall, nos faz refletir sobre os imigrantes e como Bauman aborda essa reflexão na obra Identidade (2005).

Bauman nos faz refletir sobre a questão de identidade e pertencimento. $O$ autor define que existem dois tipos de comunidade, são elas "de vida" e "de destino": ele fala sobre sua situação que, nascido na Polônia, foi proibido de lecionar e mudou-se para a Inglaterra. Anos depois, encontrou-se em dilema ao definir sua identidade. Para o autor, só existe o questionamento do indivíduo sobre a própria identidade quando há uma exposição a outra comunidade, ou seja, a de "destino":

Tornamo-nos conscientes de que "pertencimento" e a "identidade" não têm a solidez de uma rocha, não são garantidos para toda a vida, são bastante negociáveis e revogáveis, e de que as decisões que o próprio indivíduo toma, os caminhos que percorre, a maneira como age - e a determinação de se manter firme a tudo isso - são fatores cruciais para o "pertencimento" quanto para a "identidade". Em outras palavras, a ideia de "ter uma identidade" não vai ocorrer às enquanto o "pertencimento" continuar sendo o seu destino, uma condição sem alternativa. Só começarão a ter essa ideia na forma de uma tarefa a ser realizada, e realizada vezes e vezes sem conta, e não de uma só tacada. (BAUMAN, 2005, p.17-18).

O autor diz também que é bem improvável que um indivíduo passe apenas por uma única "comunidade de ideias e princípios", ou seja, estamos e entramos em contato com diversas comunidades, o que reflete na nossa identidade. Nossa identidade, segundo o sociólogo, "é revelada como algo a ser inventado, e não descoberto" (BAUMAN, 2005, p. 21).

\subsubsection{A identidade nas entrevistas}

As teorias sobre identidade podem ser exemplificadas através de trechos das entrevistas coletadas. Alguns entrevistados trazem essa problemática para 0 momento da entrevista, apresentando reflexões sobre suas próprias identidades, e que, no caso dos descendentes, podem ser duplas a respeito da nacionalidade, brasileira e italiana.

\footnotetext{
${ }^{8}$ Aspas e itálico utilizados pelo autor.
} 
Nas nossas entrevistas, muitas vezes o entrevistado se questiona sobre sua identidade durante o tempo da conversa. Podemos ver no trecho abaixo, que a entrevistada chama atenção para sua identidade:

05" A: Boa noite. É um prazer estar aqui.

G: Obrigada.

09" A: Colaborando com a pesquisa de vocês. Espero poder conseguir responder e ajudar nessa pesquisa, iá que é uma coisa que realmente tem a ver comigo, com a minha família, com a minha identidade. Com uma das minhas identidades ${ }^{9}$. Que a outra é brasileira, não tem jeito. Mas me toca muito falar desse... Dessa temática aí do projeto de vocês.

Neste trecho, é possível observar a consciência que a entrevistada tem sobre suas múltiplas identidades nas seguintes frases: "já que é uma coisa que realmente tem a ver comigo, com a minha família, com a minha identidade. Com as minhas identidades. O uso do possessivo "minha/minhas", do pronome pessoal "comigo", da palavra "família", em contraposição da frase "a outra [identidade] é brasileira, não tem jeito", nos remete que só é possível ter uma reflexão sobre isso se já houve um questionamento a respeito de sua própria identidade em outros momentos, Bauman nos explica que:

Afinal de contas, perguntar "quem você é" só faz sentido se você acredita que possa ser outra coisa além de você mesmo; só se você tem uma escolha, e só se o que você escolhe depende de você; ou seja, só se você tem de fazer alguma coisa para que a escolha seja "real" e se sustente. (BAUMAN, 2005, p.25)

Considerando a entrevistada citada acima, só existe essa definição de "dupla" identidade por existir um questionamento sobre qual identidade seguir. A questão da dupla identidade é marcada em outras entrevistas. Em alguns casos, o entrevistado tem a dupla cidadania, o que pode contribuir ainda mais para essa dupla identidade.

30" J: Posso dizer duas coisas primeiro que eu sou a única pessoa da
família dos descendentes que se interessa por isso \#
37' E: Ó:: interessante \#
39"' J: É:: sobrinhos e outros parentes parece que não querem muito se
interessar pelo passado \# a segunda coisa é que eu sou de uma família
multicultural pelo lado de pai de descendência italiana e portuguesa que é por
isso que eu tô aqui por parte de mãe alemã e francesa então é essa parte
italiana da família foi a que pra mim ficou mais é digamos assim
impregnada né foi aquela com a qual eu mais me identifico então

${ }^{9}$ De agora em diante, todos os grifos dos trechos das entrevistas são nossos. 
No trecho acima, vemos como o entrevistado fala que a parte italiana é a que ficou "impregnada" nele e é a parte que ele mais se identifica, "é essa parte italiana da família foi a que pra mim ficou mais é digamos assim impregnada né foi aquela com a qual eu mais me identifico então", ou seja, é uma das partes de sua identidade. Mesmo com outras ascendências, como a portuguesa e a alemã, a parte que permaneceu foi a italiana, devido à proximidade que o entrevistado tem com essa parte da família.

A identidade é construção, é um processo nunca acabado. Segundo Bauman, sempre existirá uma outra identidade aguardando a ser testada:

A construção da identidade assumiu a forma de uma experiência infindável. Os experimentos jamais terminam. Você assume uma identidade num momento, mas muitas outras, ainda não testadas, estão na esquina esperando que você as escolha. Muitas outras identidades não sonhadas ainda estão por ser inventadas e cobiçadas durante a sua vida. Você nunca saberá ao certo se a identidade que agora exibe é a melhor que pode obter e a que provavelmente lhe trará maior satisfação. (BAUMAN, 2005, p. 91)

Em algumas entrevistas, vemos como essa italianidade surgiu ao longo do tempo em alguns entrevistados, seja para descobrir a história da família ou para manter as narrativas familiares. No caso do trecho abaixo, por exemplo, a entrevistada nos explica que sentiu interesse nas histórias da família, o que ajudou a construir sua identidade italiana:

01" S: É\# então D. \# é::: o que você sabe de como a sua família veio para o Brasil?

06" D: É::: na verdade eu fiz uma pesquisa muito grande depois de eu ter uns quinze anos de idade porque minha família ninguém sabia de nada porque eles tinham vindo pro Brasil né minha mãe sempre me dizia que 0 meu bisavô meus dois bisavôs paternos são \# maternos desculpa são italianos mas cada um de um lugar diferente eles se conheceram no Brasil e se casaram aqui e minha mãe sempre me dizia que::: eles tinham vin- meu bisavô tinha vindo fugido da guerra \# e aí um dia conversando com a minha mãe devia tá no \# com quinze anos no primeiro colegial alguma coisa assim eu peguei o meu livro de história e falei não tinha guerra nessa época não é possível mil novecentos e onze não tinha primeira guerra mundial não tinha começado não sei o quê aí eu comecei a pesquisar e a tentar entender o que tinha acontecido até que uma prima me contou\# o que tinha acontecido o meu avô tava vivo na época e num falava nada e \# conversando com essa prima mais velha ela falou olha hã\# uma tia irmã do meu avô uma das filhas do meu bisavô me confessou uma noite passou um segredo que não sei o quê ele veio fugido pro Brasil porque \# ele tinha matado uma pessoa na Itália \# hã::: acho que aos treze anos mais ou menos eu descobri algumas cartas da::: \# a correspondência entre ele e os irmãos que ficava num \# porão que tinha na casa da minha avó que é a casa onde ele \# que ele construiu aqui em São Paulo e essas cartas elas eram muito confusas porque elas não eram escritas em italiano algumas sim em italiano algumas escritas em dialeto e::: a maior parte escrita por analfabetos né \# 
A entrevistada faz questão de destacar a sua busca individual pela história da família "eu fiz uma pesquisa muito grande depois de eu ter uns quinze anos de idade porque minha família ninguém sabia de nada porque eles tinham vindo pro Brasil", a construção e a busca por essa história é de suma importância para a entrevistada, é um sentimento de pertencimento.

Segundo Anna De Fina, a construção da identidade sempre está relacionada ao contexto, temos que considerar os tipos de interação, os argumentos utilizados durante a conversação e a relação entre os interlocutores, ou seja, é fundamental considerar o contexto em que determinada identidade foi expressa ou negociada. Ainda segundo a autora:

Em abordagens mais recentes a identidade não é vista como um conjunto de
traços psicológicos que caracterizam um indivíduo ou um grupo, mas como
uma construção discursiva (e interativa) alcançada através de uma
multiplicidade de estratégias e que não pode ser separada dos contextos em
que é expressa. (DE FINA, 2007, p 69.). (Tradução nossa) ${ }^{10}$

No trecho da entrevista abaixo, podemos notar que o entrevistado expressa a identidade italiana logo nos primeiros segundos da entrevista. Todos os entrevistados são descendentes de italianos, pois isso era um pré-requisito para a entrevista, sendo assim, não havia necessidade do entrevistado reforçar isso. Porém, ele inicia a entrevista destacando essa informação, para intensificar sua identidade italiana:

12"' E: Ah /e a gente\# tem aqui as >nossas perguntas e eu vou começar com a primeira delas e depois a gente vai conversando tranquilamente sem problemas< então a primeira pergunta é sobre as coisas é que a gente já estava um pouco comentando agora e o que você sabe de como a sua família ou as suas famílias $>>$ você disse que são duas << vei- vieram ao Brasil

34" D: É eu sou descendente de italiano dos dois lados então que vamoassim por partes a família A. que era do por parte do meu pai e a família D. que era por parte da minha mãe.

O entrevistado, ao reforçar sua ascendência, fortalece sua identidade italiana e seu sentimento de pertencimento "É eu sou descendente de italiano dos dois lados então que vamo- assim por partes a família A. que era do por parte do meu pai e a família D. que era por parte da minha mãe."

\footnotetext{
10 Negli approcci più recenti l'identità non viene infatti vista come un insieme di tratti psicologici che caratterizzano un individuo o un gruppo, ma come una costruzione discorsiva (e interattiva) che si realizza atraverso una molteplicità di strategie e che non può essere separata dai contesti in cui viene espressa. (DE FINA, 2007, p. 69).
} 
Na entrevista abaixo, novamente observamos essa questão. A entrevistadora pergunta se ela sabe como a família veio para o Brasil, já ciente do fato de que a entrevistada é descendente de italianos, mas a entrevistada destaca o fato de ter "ascendência italiana dos dois lados", ou seja, expressa sua identidade italiana:

\begin{tabular}{l} 
31" S: Eh:: o que você sabe de como sua família veio para o Brasil? \\
36" N: Olha a:: eu sou- tenho ascendência italiana pelos dois lados \\
materno e paterno hã:: do lado materno são meus dois avós eram \\
italianos e:: além disso eu tinha tios avós hã tias que também eram \\
\hline italianas do lado do meu pai só a mãe do meu pai era italiana bom \\
comeco pela família da minha mãe que é que- hã- digamos pelo lado \\
italiano a família pela qual eu tive mais contato hã:: a minha nonna que \\
era- \# na na certidão de casamento que eu tenho que eu quardo[...]
\end{tabular}

A entrevistada ressalta a sua ascendência italiana e evidencia o contato com sua família, novamente o sentimento de pertencimento "pelo lado italiano a família pela qual eu tive mais contato hã:: a minha nonna que era- na na certidão de casamento que eu tenho que eu guardo[...]".

No trecho abaixo, de outra entrevistada, é possível observar como a identidade italiana é expressa na narrativa, pois ela se inclui na narração, mesmo não se lembrando dos acontecimentos. A entrevistada é italiana e veio para o Brasil com dois anos e meio e afirma que metade da identidade dela é italiana, mesmo sem se recordar de muita coisa, ela reforça ao longo da entrevista que sua identidade é dividida em duas partes, italiana e brasileira.

02'54" A: Nós viemos pro Brasil em mil novecentos e cinquenta e sete, e... Nós paramos no Porto de Santos, ficamos um tempo, um tempo na... ali na... ali onde fica o local dos imigrantes, inclusive tem um registro que eu já vi da nossa família. Havia uma irmã do meu pai que já morava em São Paulo.

03'19"A: Então nós viemos para São Paulo, meus pais não são do campo. Eles tinham nível universitário, e meu pai era comerciante lá, minha mãe é economista. Então, nós não fomos pro campo, viemos pra São Paulo, mas meio que [com] uma mão não frente e outra atrás como todo imigrante.

03'39" G: Que idade você tinha quando você...

A: Quando eu vim pro Brasil?

G: É, exato.

A: Dois anos e meio.

$\mathrm{G}:$ Ah, pequenininha.

Em outra entrevista, por exemplo, ocorre a negação da identidade italiana, mesmo sendo um descendente na mesma situação dos outros entrevistados. O entrevistado, ao falar sobre o reconhecimento da cidadania italiana, diz que é brasileiro e não tem motivos para solicitar a cidadania: 
J: E os italianos se integraram de maneira perfeita, eu acho, no Brasil. Hoje quando me dizem, por exemplo, se eu tenho vontade de requerer a cidadania italiana, eu digo que não tenho nenhuma porque há nenhuma razão pra eu requerer a cidadania italiana, dado que eu não sou italiano, sou brasileiro.

E: Uhum.

$\mathrm{J}$ : Eu tenho muito orgulho da origem italiana que eu tenho, mas não sou italiano, sou brasileiro.

O entrevistado reconhece sua origem italiana, conta a história da sua família e as lembranças com seus avós, porém, se considera brasileiro e não se identifica italiano "Eu tenho muito orgulho da origem italiana que eu tenho, mas não sou italiano, sou brasileiro".

Em outra entrevista, vemos como o entrevistado se inclui na fala, utilizando a primeira pessoa do plural em algumas narrativas familiares, criando uma identidade italiana e a ideia de pertencer àquele povo, sem a necessidade de se distanciar do que está sendo contado:

02'31" M: Isso era muito comum essas piadas ou então o menininho italiano que ia para a escola e a professora perguntava o que vocês comeram hoje e ele falava polenta aí ele ia pra casa e os pais perguntavam o que ele fez na escola e ele falava que a professora perguntou o que a gente comeu em casa e o que você disse? Polenta não mas você tem que falar que comeu $\overline{\text { arroz }}$ aí ia pra escola e a professora perguntava <o que você comeu hoje? Polenta- arroz quantos pratos? três fetas

(risos)

03'09" E: Mas essa história quem contava?

03'12" M: Se contava assim entre nós mesmos a pessoa ri de si mesmo uma coisa engraçada na família da da minha avó ela (não entendi) acho meio tocante isso sabe? Eles não sabiam falar nada falavam dialeto veneto e aí eles precisavam comprar sabão e chegaram numa venda num armazém e pediram isso aqui aí eles passavam na roupa e juntava mosca ao invés de limpar ficava juntando mosca quando foram ver era rapadura essas coisas são folclóricas né?

O entrevistado utiliza a primeira pessoa para narrar o acontecimento, se incluindo na história, ou seja, a história da família italiana passa a ser a sua própria história: "a professora perguntou o que a gente comeu em casa".

A análise do contexto da entrevista é fundamental para a verificação da identidade italiana, pois permite um distanciamento. É possível fazermos narrações de histórias sem pertencer a elas. Quando os entrevistados demonstram um pertencimento em relação às histórias, principalmente por serem histórias relacionadas à família, acabam evidenciando uma identidade italiana, que muitas vezes estava apagada antes de começarmos a falar sobre as narrativas familiares.

Anna De Fina destaca a importância do contexto: 
A identidade não pode ser analisada fora do contexto em que é negociada, porque é o resultado de um trabalho interacional no sentido de envolver todos os interlocutores e que depende do posicionamento de ambos. ${ }^{11}$ (FINA, 2007, p.86) (Tradução nossa).

\subsection{MEMÓRIA E IDENTIDADE}

Esta seção tem como objetivo analisar a importância da memória na construção da identidade. Utilizaremos como base teórica os pensamentos de Maurice Halbwachs (2003), Paul Riceur (2007) e Michael Pollak (1992). A memória está diretamente ligada à construção da identidade do sujeito, seja através de manifestações sociais ou coletivas.

\subsubsection{A memória e a construção da identidade}

Para iniciar este capítulo, é importante considerar que a identidade do indivíduo é posterior a memória, segundo Pollak:

(...) a memória é um elemento constituinte do sentimento de identidade, tanto individual como coletiva, na medida em que ela é também um fator extremamente importante do sentimento de continuidade e de coerência de uma pessoa ou de um grupo em reconstrução de si. (POLLAK, 1992, p.204)

Autores como Halbwachs e Pollak defendem que a identidade só existe graças à memória. Diante disso, é possível afirmar que muito da identidade italiana presente nos entrevistados foi construída pelas memórias cultivadas pelos familiares e pelos entrevistados e em alguns casos podemos chamar, segundo Pollak (1992), de "memória herdada".

Maurice Halbwachs explica que a memória coletiva é sempre predominante diante da memória individual, pois, segundo o autor, nunca estamos sozinhos. A nossa memória sempre é resultado de influências de grupos que fazemos parte, como família, amigos, entre outros. No trecho abaixo, é possível compreender o seu pensamento sobre "nunca estarmos sós":

Nossas lembranças permanecem coletivas e nos são lembradas por outros, ainda que se trate de eventos em que somente nós estivemos envolvidos e

\footnotetext{
11 “'L'identità non può venire analizzata al di fuori del contesto in cui viene negoziata perché è frutto di un lavoro interazionale nel senso che coinvolge tutti gli interlocutori e che dipende dal loro reciproco posizionarsi." (FINA, 2007, p. 86)
} 
objetos que somente nós vimos. Isto acontece porque jamais estamos sós. Não é preciso que outros estejam presentes, materialmente distintos de nós, porque sempre levamos conosco e em nós certa quantidade de pessoas que não se confundem. (HALBWACHS, 2003 p.30)

A construção da identidade, como vimos, é sempre a relação entre o "eu" e a sociedade, ou seja, a identidade individual sempre reflete os grupos com quem está estabelecido um relacionamento e convívio e isso aparece, inclusive, em nossas memórias, que também são construídas, pois muitos elementos da memória são excluídos, e segundo Pollak, existe um trabalho de organização da memória.

Pollak também fala sobre a constituição da memória e a relação com a identidade. O autor fala sobre os três elementos principais da constituição da memória e, em seguida, fala sobre identidade:

Há a unidade física, ou seja, o sentimento de ter fronteiras físicas, no caso do corpo da pessoa, ou fronteiras de pertencimento ao grupo, no caso de um coletivo; há a continuidade dentro do tempo, no sentido físico da palavra, mas também no sentido moral e psicológico; finalmente, há o sentimento de coerência, ou seja, de que os diferentes elementos que formam um indivíduo são efetivamente unificados. (...) Podemos portanto dizer que a memória é um elemento constituinte do sentimento de identidade (...) (POLLAK, 1992, p.204)

Por nossas entrevistas serem baseadas em histórias de família, aproximaramse das reflexões de Michael Pollak sobre a memória e a identidade social (1992). Segundo o pensador, mesmo diante do caráter "flutuante" e "mutável" da memória, existem alguns acontecimentos que são "invariantes":

Todos os que já realizaram entrevistas de histórias de vida percebem que no decorrer de uma entrevista muito longa, em que a ordem cronológica não está sendo necessariamente obedecida, em que os entrevistados voltam várias vezes aos mesmos acontecimentos, há nessas voltas a determinados períodos da vida, ou a certos fatos, algo de invariante. É como se, numa história de vida individual - mas isso acontece igualmente em memórias construídas coletivamente - houvesse elementos irredutíveis, em que o trabalho de solidificação da memória foi tão importante que impossibilitou a ocorrência de mudanças. (POLLAK, 1992, p. 201)

Em seu estudo sobre a colônia italiana, Pedrinhas Paulista, Giliola Maggio verifica como a memória do imigrado é uma construção coletiva:

Viu-se que, numa comunidade estruturada como Pedrinhas, a memória do imigrado não é apenas algo individual: há traços de memórias individuais que se somam na memória coletiva dos integrantes dessa comunidade, chegando a formar um belo quadro onde cada um deixou sua pincelada pessoal, integrando-a à contribuição dos outros. (CASTRO, 2002, p.128) 
Nas entrevistas, é possível observar como a memória dos familiares deixam marcas na memória do entrevistado, pois muitas histórias que são contadas não foram vividas pelo entrevistado. O trecho da entrevista abaixo, por exemplo, demonstra que a memória da entrevistada foi criada por intermédio de outra pessoa:

D: minha mãe sempre me dizia que o meu bisavô meus dois bisavôs paternos são \# maternos desculpa são italianos mas cada um de um lugar diferente eles se conheceram no Brasil e se casaram aqui e minha mãe sempre me dizia que::: eles tinham vin- meu bisavô tinha vindo fugido da guerra \# e aí um dia conversando com a minha mãe devia tá no \# com quinze anos no primeiro colegial alguma coisa assim eu pequei o meu livro de história e falei não tinha querra nessa época não é possível mil novecentos e onze não tinha primeira querra mundial não tinha comecado não sei o quê aí eu comecei a pesquisar e a tentar entender o que tinha acontecido até que uma prima me contou\# o que tinha acontecido o meu avô tava vivo na época e num falava nada e \# conversando com essa prima mais velha ela falou olha hã\# uma tia irmã do meu avô uma das filhas do meu bisavô me confessou uma noite passou um segredo que não sei o quê ele veio fugido pro Brasil porque \# ele tinha matado uma pessoa na Itália \#

As histórias contadas pela mãe e pela prima foram fundamentais para a criação da memória da entrevistada: "e aí um dia conversando com a minha mãe [...] até que uma prima me contou", como uma colcha de retalhos, ela construiu a sua própria memória com base nas histórias compartilhadas.

As memórias sobre os bisavôs foram criadas pela mãe e pela prima, pois elas conheciam a história dessas pessoas e a repassaram para a entrevistada que repassou isso para o entrevistador. As histórias contadas na entrevista não foram vivenciadas pela entrevistada, são memórias construídas em seu ciclo familiar, porém, essas histórias sobre os parentes italianos influenciaram sua vida e sua identidade:

07'25" D: Eu queria entender porque minha família tava aqui né porque eu me encontrava em São Paulo se eles tinham \# se a gente tinha essa raiz italiana se a gente sempre tinha dentro da minha família uma italianidade muito forte sei que tava vinculada a algum lugar vinculada a um país que ninguém entendia o porquê exatamente e foi por isso que eu comecei a estudar italiano pra tentar entender essas cartas \# e eu só consegui realmente entender depois que eu passei um tempo com a minha família lá porque eu acabei reencontrando os hã sobrinhos do meu bisavô que o conheceram que sabiam de toda a história e que me contaram toda a história e aí eu comecei a entender um pou- entender \# consegui me orientar dentro do::: do dialeto deles do jeito que eles falavam e aí lendo as cartas as vezes até em voz alta pra poder entender e conseguir reconstruir a história dele né como ele porque ele tinha saído o que tinha acontecido (...)

A busca pela origem familiar contribuiu diretamente para a construção da italianidade da entrevistada: "Eu queria entender porque minha família tava aqui né porque eu me encontrava em São Paulo se eles tinham \# se a gente tinha essa raiz 
italiana". Neste trecho também há a substituição do "eles" por "a gente", ou seja, entrevistada se inclui na narrativa, demonstrando sua "raiz italiana".

As entrevistas trabalham diretamente com as lembranças dos entrevistados, pois o roteiro faz perguntas sobre a história da família que veio para o Brasil, essas memórias podem ser tão fortes e intensas que reforçam a presença de uma "memória herdada" entre os entrevistados:

É perfeitamente possível que, por meio da socialização política, ou da socialização histórica, ocorra um fenômeno de projeção ou de identificação com determinado passado, tão forte que podemos falar numa memória quase que herdada. (POLLAK, 1992, p.201)

Na próxima entrevista, logo no início a entrevistada também faz questão de explicar que as suas memórias foram construídas pelos familiares:

A. então, é uma memória que fica com pouco perdida, então você precisa ficar procurando por perguntas, perguntando pros mais velhos. O que eu sei é que eles vieram de navio né, os meus bisavós vieram de navio pro Brasil, na segunda metade do século XIX. A parte paterna da minha família foi pro interior do Estado de São Paulo, então ali perto de Rio Claro se instalaram por ali e trabalhando em fazenda né?

A busca por informações através de outros familiares: "então você precisa ficar procurando por perguntas, perguntando pros mais velhos" demonstra uma construção de memória coletiva a respeito das histórias de família.

Como observamos anteriormente, não é possível falar de identidade sem falar de memória. A memória, assim como a identidade, é um processo de construção. $E$ essas construções da memória refletem na constituição da identidade do indivíduo, algumas de maneira mais intensa, como é o caso da memória herdada:

Se podemos dizer que, em todos os níveis, a memória é um fenômeno construído social e individualmente, quando se trata da memória herdada, podemos também dizer que há uma ligação fenomenológica muito estreita entre a memória e o sentimento de identidade. (POLLAK, 1992, p.204)

Para a entrevistada abaixo, contar a história da família está diretamente ligado a falar sobre uma de suas identidades. Ao longo da entrevista ela revela diversas informações que não se lembra nitidamente, mas fala como os familiares são importantes para preservar a história da família, como citar o irmão, que deve lembrar de mais histórias: 


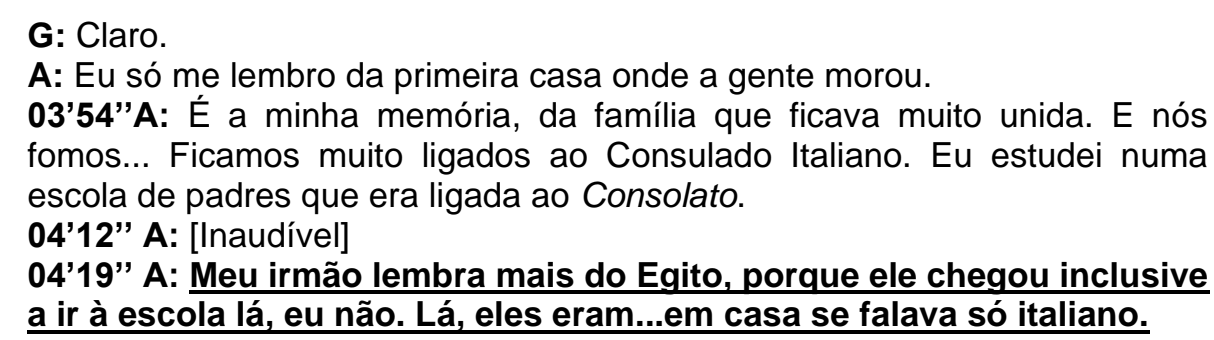

Neste trecho "Meu irmão lembra mais do Egito, porque ele chegou inclusive a ir à escola lá, eu não. Lá, eles eram...em casa se falava só italiano”. Ela destaca a informação de que o irmão lembra de mais coisa, ou seja, a história ainda está preservada em alguém.

As memórias familiares são sempre presentes porque trabalhamos com histórias de imigração e, no caso dos italianos no Brasil, foi uma imigração familiar que envolvia muitos membros. Os descendentes que foram entrevistados buscaram as lembranças através da memória de outros familiares, por isso não podemos falar de memórias individuais, pois todas elas sofrem influências de outras pessoas, sejam pais, irmãos, avós ou tios.

Outro ponto importante no caso deste estudo que envolve os descendentes é, manter a memória é como manter o sentimento de pertencimento, conforme explica Pollak:

A memória, essa operação coletiva dos acontecimentos e das interpretações
do passado que se quer salvaguardar, se integra, como vimos, em tentativas
mais ou menos conscientes de definir e de reforçar sentimentos de
pertencimento e fronteiras sociais entre coletividades de tamanhos
diferentes: partidos, sindicatos, religiões, clãs, famílias, nações etc.
(POLLAK, 1989, p.9)

Alguns entrevistados falam sobre o sentimento de pertencimento que envolve a família italiana e a Itália, o que faz o entrevistado preservar as histórias:

15'38' M: Mas veja como é que eu sempre sentindo aquela coisa assim mas eu num mas veja como aquela viagem para Roma foi interessante pra mim claro Roma é sempre interessante é uma cidade particularmente interessante e isso mexeu comigo de uma forma extremamente positiva mas caminhando por Roma andando assim hã aí eu senti assim uma coisa assim puxa vida claro (inaudível) isso não tinha nada a ver com Roma mas é parte desse universo aqui né aí foi umas tem uma uma coisa senti um certo (inaudível) isso que me fez mal por que eu tố sentindo isso? Coisa imbecil não tem nada a ver (não entendi) todo francês vai achar que é Vitor Hugo? Num faz sentido né?

No trecho acima, o entrevistado fala sobre o sentimento de pertencimento que sentiu quando chegou em Roma, a sensação de fazer parte da cultura italiana. Essa 
ideia foi construída pelo contato que teve com seus familiares e as histórias contadas ao longo dos anos. A preservação dessas histórias pelos entrevistados contribui para a construção da identidade do entrevistado.

Podemos ver, no trecho abaixo, como o entrevistado diz que a preservação das lembranças contribuiu para a construção da sua identidade, já que é a parte da família com a qual ele mais "se identifica":

30" J: Posso dizer duas coisas primeiro que eu sou a única pessoa da família dos descendentes que se interessa por isso \#

37' E: Ó:: interessante \#

39" J: É:: sobrinhos e outros parentes parece que não querem muito se interessar pelo passado \# a segunda coisa é que eu sou de uma família multicultural pelo lado de pai de descendência italiana e portuguesa que é por isso que eu tô aqui por parte de mãe alemã e francesa então é essa parte italiana da família foi a que pra mim ficou mais é digamos assim impregnada né foi aquela com a qual eu mais me identifico então.

A necessidade de mostrar que é o único que pesquisou a história da família e como a parte italiana da família ficou impregnada: "com a qual eu mais me identifico então".

As histórias da família viraram objetos de pesquisa para alguns descendentes, em alguns casos, reconstruir as memórias familiares poderiam auxiliar no reconhecimento da cidadania italiana, por exemplo, na entrevista abaixo:

01'05" D: com quem eu tive mais contato os A. então eu me especializei mais nas minhas pesquisas pela família $A$. tanto que eu pequei a cidadania italiana po- por essa linhagem do meu bisavô avô pai e chegou até a mim.

01'20" E: uhum

01'21" D: Então o que eu descobri sobre os A.? Eles moravam num município chamado numa cidadezinha chamada Paese que é do lado de Treviso

01'33" E: Treviso.

01'34" D: E.. tanto que saíram diversos A. daquela região. [E: uhum] a /L. A. que é a única maestrina no Brasil e também é bem próxi- porque $D$. A. L .A. ela saiu também da região de Treviso mas de um outro lado como se fosse São Paulo São Paulo Osasco Zona Oeste São Paulo Guarulhos Zona Leste entã::o \# os A. no caso do meu bisavô eles moravam nessa cidadezinha chamada Paese >que eu cheguei a visitar depois< continua pequena e:: segundo a minha tia que até eu consultei ela pra por causa desse trabalho agora dessa entrevista uma coisa interessante que eu nu::m sabia desse fato que eles saíram porque eles eram lavradores e eles plantavam melancias [02'27' E: ah] e na época teve uma:: epidemia muito grande e que matou muita gente e que o governo achou que era por causa da da melancia que que se proliferava na melancia e acabou com todas as plantações de melancia 
O entrevistado fala que a tia auxiliou na busca das informações sobre a família "segundo a minha tia que até eu consultei", a reconstrução da história da família ocorre por diversos motivos, seja por busca pela cidadania ou para compartilhamento da história.

A pesquisa nos mostrou como alguns descendentes estavam empenhados em compartilhar a história e suas lembranças ao ceder a entrevista. Em todos os entrevistados é impossível negar a presença da memória coletiva, já que todas as lembranças são construídas a partir de lembranças de outros familiares e demais pessoas que viveram ou que viram determinado fato ocorrer.

Os estudos de Pollak falam sobre a importância de envolver a História Oral nos estudos de memória, pois

Ao privilegiar a análise dos excluídos, dos marginalizados e das minorias, a História Oral ressaltou a importância de memórias subterrâneas que, como parte integrante das culturas minoritárias e dominadas, se opõem à "memoria oficial", no caso a memória nacional. (POLLAK, 1989, p. 4)

No caso das nossas entrevistas é interessante notar que as lembranças e memórias que são contadas pelos entrevistados são, muitas vezes, diferentes do que as literaturas sobre imigração trazem. Assim, os motivos da imigração, por exemplo, muitas vezes aparecem diferentes dos motivos que os livros nos apresentam, criando uma outra perspectiva sobre o assunto.

\subsubsection{As histórias e a memória}

O roteiro todo das entrevistas é relacionado com a memória dos entrevistados, pois as entrevistas são relacionadas às histórias de famílias. A pergunta "você se lembra de alguma história sobre a Itália que se conta(va) na sua casa?", nos mostra como as lembranças dos entrevistados sempre estão relacionadas a outras pessoas, reforçando a teoria de Halbwachs sobre a dificuldade de reconstruir essas lembranças sozinhos:

É difícil encontrar lembranças que nos levem a um momento em que nossas sensações eram apenas reflexos dos objetos exteriores, em que não misturássemos nenhuma das imagens, nenhum dos pensamentos que nos ligavas a outras pessoas e aos grupos que nos rodeavam. Não nos lembramos de nossa primeira infância porque nossas impressões não se 
ligam a nenhuma base enquanto ainda não nos tornamos um ser social. (HALBWACHS, 2003, p. 43)

Nas entrevistas é possível ver como outras pessoas auxiliaram na manutenção das lembranças:

\begin{abstract}
J: Porque eles vieram, é, pro Brasil pra ser agricultores. E, então a história deles no Brasil, isso era contado, contado com muito orgulho. $\dot{E}$, de todo o trabalho que eles, porque eles trabalharam demais, demais, demais. $E$ então isso era sim contado com muito orgulho.
\end{abstract}

$\mathrm{Na}$ entrevista acima, o entrevistado fala que a história dos familiares era contada com muito orgulho, mas ele não explica por quem era contada: "a história deles no Brasil, isso era contado, contado com muito orgulho". Dessa maneira, o entrevistado destaca o sentimento de orgulho que estava envolvido e um pouco mais a frente, na mesma entrevista, notamos que uma lembrança que ocorreu por volta de 1912 é contada até os dias de hoje, ou seja, mais de 100 anos de preservação de uma memória:

J: É, onde havia, isso foi, se não me falha a memória, em 1911 ou 1912. por aí. Eles, é, compraram terras em Biriqui, e vieram pra Biriqui onde eles derrubaram a mata e plantaram café. E foram cafeicultores, é, durante um tempo, é, longo. Mais adiante, eles abriram uma pensão, hum, que era como se chamava esses hotéis modestos, na cidade de Birigui.

Halbwachs fala sobre o esquecimento que "esquecer um período da vida é perder o contato com os que então nos rodeavam." (HALBWACHS, 2003, p.37), muitas vezes, o familiar pode ter, ao longo dos anos, se distanciado de sua família, o que pode gerar o esquecimento das histórias.

Em uma entrevista, por exemplo, notamos que o entrevistado não tem muita ligação com a história da família, pois a mãe não gostava de falar sobre essas histórias com ele, e quem mantinha a lembrança ativa nele era a avó, com quem ele falava italiano:

11'38" D: Tinha uma coisa assim que era- quando era pequeno que eu perguntava, minha mãe é- minh- minha mãe nunca gostou muito de falar disso sabe... minha avó mais que falava porque eu pedia pra minha avó falar italiano comigo quando eu era pequeno...

O entrevistado pedia para a avó falar italiano com ele quando era pequeno: "eu pedia pra minha avó falar italiano comigo quando eu era pequeno", o que contribuía para a preservação da língua e da história da família.

A preservação e a manutenção das histórias e das lembranças aparecem em entrevistas de entrevistados que tem um forte vínculo familiar, refletindo, assim, em 
histórias contadas em muitos detalhes, como marcação cronológica da história, identificação de personagens, local, entre outros. Podemos perceber, por exemplo, no trecho da entrevista abaixo, que o entrevistado sabe até o nome do navio de embarque de seus familiares:

03'59" D: E aí eles embarcaram naqueles dados que eu de, e que vou fornecer pra vocês no passaporte é e:: vieram num navio chamado Berni Bearn até na minha pesquisa me confundiu porque o:: eles vieram em mil oitocentos e oitenta e oito e o Bearn era de mil oitocentos e oitenta e um sete anos era um navio relativamente novo

Esse detalhe do nome do navio e a data do navio: "Bearn era de mil oitocentos e oitenta e um sete anos era um navio relativamente novo" demonstra que o entrevistado fez uma pesquisa muito detalhada sobre a vida e a história dos familiares, a necessidade de saber os mínimos detalhes da história.

Halbwachs nos fala sobre a importância de nos orientarmos também por lembranças de terceiros, pois isso ajuda a fortalecer a nossa lembrança e impressão:

Claro, se a nossa impressão pode se basear não apenas na nossa lembrança, mas também na de outros, nossa confiança na exatidão de nossa recordação será maior, como se uma mesma experiência fosse recomeçada não apenas pela mesma pessoa, mas por muitas. (HALBWACHS, 2003, p.29)

Os entrevistados utilizam a recordação de outras pessoas para fortalecer suas próprias lembranças sobre as histórias familiares, tentando tornar os fatos mais verdadeiros. Em todas as entrevistas aparece esse fenômeno, pois são histórias que aconteceram entre 1880 e 1920 e os descendentes não vivenciaram as histórias e só puderam conhecê-las por meio das lembranças de terceiros:

04'56" J: É:: não inclusive aí tem que se dizer é quando eu tentei fazer um
levantamento do da origem da família com alquns dos tios do meu pai
ainda vivos principalmente com essa que era a C. ela ficou muito
constrangida eu pedi pra ela documentos dos avós etc e ela ficou muito
constrangida depois o meu pai ela disse que não tinha mais nada que
tinha queimado tudo e aí meu pai uma vez me chamou e constrangido
também e disse que era possível que meu avô já fosse casado na Itália
antes de vir pro Brasil o que era uma coisa bastante hã::

No trecho acima, o entrevistado conta que a busca pela história da família foi através dos tios, tia e o pai que auxiliaram na reconstrução da história. Se não fossem eles, o entrevistado não teria o que contar. As outras pessoas da família foram fundamentais para essa reconstrução.

Paul Ricoeur, que segue o pensamento de Maurice Halbwachs, nos fala sobre pertencimento: "[...] o sentimento da unidade do eu deriva desse pensamento coletivo. É por intermédio da consciência que consideramos, a cada momento, pertencer simultaneamente a vários meios [...]" (RICOUER, 2007, p.133). 
No trecho da entrevista abaixo, podemos ver como a entrevistada fala sobre seu sentimento de pertencimento que está ligado ao italiano, além da sua nacionalidade brasileira: "33'15" N: [...] é uma emocão muito grande e eu sinto que há um lado meu muito italiano \# muito italiano ainda (risos)".

Na mesma entrevista, a entrevistada fala sobre a vontade de preservar a memória ligada à história da família:

33'10" N: mas o meu registro é um pouco esse eu nunca tive problemas eu ao contrário sempre me orgulhei muito e sempre quis hã:: manter a memória cultivar ler a respeito hã saber fui pra Itália mais de uma vez hã adorei hã é uma emocão muito grande.

A entrevistada demonstra que sempre quis conhecer e saber mais sobre sua família e a vontade de preservar a história: "manter a memória cultivar ler a respeito hã saber fui pra Itália mais de uma vez".

A preservação da memória é um sinal de afetividade. Os entrevistados demonstram orgulho ao falar sobre a preservação e da manutenção das histórias familiares. Em algumas entrevistas, o entrevistado enfatiza logo no início, que ele é o responsável por manter ou por descobrir aquelas histórias:

30"' J: Posso dizer duas coisas primeiro que eu sou a única pessoa da
família dos descendentes que se interessa por isso \#
37'" E: Ó:: interessante \#
39" J: É:: sobrinhos e outros parentes parece que não querem muito se
interessar pelo passado \# a segunda coisa é que eu sou de uma família
multicultural pelo lado de pai de descendência italiana e portuguesa que é
por isso que eu tô aqui por parte de mãe alemã e francesa então é essa parte
italiana da família foi a que pra mim ficou mais é digamos assim impregnada
né foi aquela com a qual eu mais me identifico então [...]

A memória e as lembranças fortalecem a identidade italiana nos entrevistados, pois criam a própria história do indivíduo. Não podemos pensar na identidade sem a memória, pois, é uma identificação com tudo o que foi vivido pelos familiares, por isso, a necessidade de preservação das histórias de família.

No próximo item abordaremos a influência da cozinha na construção da identidade.

\subsection{COZINHA E IDENTIDADE}

A presente seção tem como objetivo analisar a relação entre cozinha e identidade italiana. Como base teórica, utilizaremos os estudos de Massimo 
Montanari, Franco Cenni, Silvana Azevedo de Almeida, Camilla Cattarulla e Janine Helfst Leicht Collaço sobre a questão da cozinha como forma de manifestação de identidade e como o Brasil, em especial São Paulo, recebeu a culinária italiana.

\subsubsection{A cozinha italiana no brasil}

A cozinha italiana deixou marcas em diversos estados brasileiros, principalmente naqueles que receberam grande número de imigrantes italianos, o que acabou influenciando diretamente a culinária local. Podemos citar, por exemplo, o caso das vitícolas na região Sul do Brasil, que segundo Cenni:

Sem dúvida, a notável expansão vitícola do Rio Grande do Sul se deve aos colonos italianos, que nos primeiros anos de sua permanência haviam procurado adaptar à nova terra aos bacelos que tinham trazido da Europa. Mas a produção não se desenvolvia mal dando para o consumo normal da própria família, pois o vinho é bebida tradicional e indispensável para os italianos do Norte, principalmente durante as refeições. (CENNI, 2011, p. 158)

O autor destaca a presença forte do pão, vinho e polenta no Sul do Brasil, região que também recebeu uma quantidade expressiva de imigrantes italianos. Tais alimentos, além da massa, são sempre citados nas entrevistas analisadas para a pesquisa, como podemos ver no trecho da entrevista a seguir:

J: Como alimento né... como alimento... a bebida principal do italiano é vinho... mas eu tomava desde pequeno... e minha mãe dava por outro motivo... pra nós éramos em 6 né... ela dava sangria... sangria já era pra gente dormir mais cedo quietinho pra não fazer tanta bagunça (risos)... vai dar uma amortecida né...

C: (risos) acalmar a criança...

13'01" J: É... põe um pouquinho de açúcar... (inaudível) ah... uma coisa que tinha que ter muita observância... é o respeito ao pão... o pão é coisa sagrada... talvez isso venha de religião...

No trecho acima, o entrevistado destaca a importância do pão para sua família, considerado um alimento "sagrado", ele destaca também o vinho, considerada "a bebida principal do italiano". Na mesma entrevista, um pouco mais a frente, ele destaca a polenta como um alimento bastante consumido por sua família:

J: É... então... o pão de cabeça para baixo... mas não sei... sabe essas coisas que a gente vai aprendendo... eu lembro que tinha a polenta...tinha polenta...

C: Vocês cantavam uma música também da polenta? (Risos)

J: Não... não...não...não não... não... 
A polenta, além do pão e do vinho, é outro alimento citado pelo entrevistado, porém, a família não foi para o Sul do Brasil, eles habitaram o interior de São Paulo, trazendo esses hábitos do Norte da Itália, Údine, segundo o entrevistado.

São Paulo foi o estado brasileiro que mais recebeu imigrantes italianos, devido às fazendas de café. Este fato refletiu sobre diversos aspectos da cultura paulista, inclusive na culinária.

A cidade de São Paulo tem diversos restaurantes e eventos que estão ligados à cozinha italiana. A abertura do Eataly, em 2015, segundo Almeida ${ }^{12}$, foi um marco especial, pois torna a culinária italiana ainda mais presente na cidade.

É importante ressaltar o fato dessa culinária ter como base principal o trigo para desenvolvimento das massas e da forte presença da mulher à frente seja da cozinha, seja de um estabelecimento comercial. A pesquisadora Janine Collaço ${ }^{13}$ destaca em seu texto a origem das cantinas, que criaram força em São Paulo:

Em algum momento, certas mulheres - as mammas, como são referidas -
ofereceram aos paisani pratos por ela preparados e servidos em pequenas
mesas rústicas dispostas em frente aos locais de moradia, em geral cortiços.
Eram refeições feitas em casa, com receitas pouco elaboradas, ingredientes
acessíveis, uma atividade destinada ao incremento dos proventos
domésticos, mas que trouxe também a possibilidade de um convívio mais
intenso entre os imigrantes, além de dar início àquelas que anos mais tarde
ficariam conhecidas como cantinas, restaurantes associados à imigração
italiana e que se tornaram um marco na cidade. (COLLAÇO, 2012, p.214)

A culinária foi se desenvolvendo e sofrendo adaptações com os alimentos que os imigrantes encontravam aqui. Outro ponto que merece ser comentado é a tardia unificação italiana, que ocorreu entre 1815-70, ou seja, a culinária desenvolvida pelos imigrantes era o que se comia na região que eles habitavam e não uma comida conhecida de norte a sul do território italiano.

Outro ponto importante é o oferecimento da farinha de trigo na cidade de São Paulo, que, segundo Collaço, colaborou para o desenvolvimento gastronômico:

é preciso pensar que a cidade ofereceu maior abundância de alimentos aos imigrantes, nem tanto pela variedade de ingredientes, mas pela facilidade em acessar produtos valorizados, como a farinha de trigo. Este aspecto trouxe a

\footnotetext{
${ }^{12}$ Almeida, Silvana Azevedo de, O léxico da cozinha italiana em São Paulo: autenticidade e adaptação nos restaurantes paulistanos. Dissertação (Dissertação em Letras) - USP. São Paulo, p.1-6. 2016.

${ }^{13}$ Janine Helfst Leicht Collaço, "Imigração e cozinha italiana na cidade de São Paulo ", Anuário Antropológico [Online], I | 2012, posto online no dia 01 outubro 2013, consultado no dia 15 novembro 2019. URL : http://journals.openedition.org/aa/327 ; DOI : 10.4000/aa.327
} 
noção de fartura, pois uma vez disponível este produto, ele pôde ser explorado de inúmeras formas, multiplicando seus resultados em uma vasta variedade de pães, pizzas e massas, embora restritos ao consumo étnico praticado nos bairros. A comida italiana não era então alimento para os moradores locais, apesar de, com o correr dos anos, ter se tornado extremamente aceitável e parte do lazer urbano. Não se trata de uma necessidade ou utilidade, na verdade houve a incorporação de novas circunstâncias ao comer, o que permitiu o transbordamento de fronteiras. (COLLAÇO, 2012, p.216)

Os italianos imigrantes da cidade de São Paulo se concentraram nos bairros da Barra Funda, Mooca, Bela Vista, Bixiga e Brás, devido aos imigrantes, as receitas italianas se difundiram nesses bairros, onde abriram diversos restaurantes e cantinas.

Essa tradição se perpetua em São Paulo ainda hoje, com grandes números de pizzarias e demais restaurantes típicos. A cultura italiana no Brasil sempre é lembrada pela lasanha, macarrão e o vinho.

\subsubsection{Identidade e comida}

A comida é um elemento cultural, que representa a identidade de um povo. Nos dias de hoje, o assunto gastronômico deixou de ficar apenas nas "cozinhas" e passou a ser elemento de estudo, pois através da comida é possível verificar questões ligadas à identidade nacional, classes sociais e tradições.

Catarrulla, em seu texto, traz a definição de Roland Barthes sobre o que é a comida: "ao mesmo tempo, um sistema de comunicação, um corpo de imagens, um protocolo de usos, situações e comportamentos." (Catarrulla apud R. Barthes, em "Identità culinarie in Sudamerica, Roma, 2017, tradução nossa). ${ }^{14}$ Esta definição do filósofo francês nos faz refletir sobre a identidade de uma família de origem italiana que decide manter, ou não, os pratos e receitas tradicionais da família.

Para Massimo Montanari, a comida pode ser comparada à linguagem:

Exatamente como a linguagem, a cozinha contém e expressa a cultura de quem a pratica, é depositária das tradições e das identidades de grupo. Constitui, assim, um extraordinário veículo de autorrepresentação e de comunicação: não apenas é instrumento de identidade cultural, mas talvez seja o primeiro modo para entrar em contato com culturas diversas, já que consumir o alimento alheio parece mais fácil - mesmo que apenas na aparência - do que decodificar-lhe a língua. Bem mais do que a palavra, a comida auxilia na intermediação entre culturas diferentes, abrindo os sistemas culinários a todas as formas de invenções, cruzamentos e contaminações." (MONTANARI, 2009, p. 11)

\footnotetext{
14 "nello stesso tempo um sistema di comunicazione, um corpo di immagini, um protocolo di usi, di situazioni e di comportamenti."
} 
As identidades culturais estão presentes nos experimentos gastronômicos, 0 que justifica a existência de tantos restaurantes de diversas nacionalidades em São Paulo, já que é uma cidade que recebe povos de vários países, segundo Almeida ${ }^{15}$, existem mais de 12.000 restaurantes estrangeiros.

Nas dez entrevistas analisadas para este trabalho, todos os entrevistados falaram sobre comida, sejam receitas, ingredientes ou hábitos alimentares de seus familiares italianos. A comida sempre foi a aproximação entre os familiares, por exemplo, os almoços fartos realizados aos domingos feitos pelas nonnas. ${ }^{16}$

Outra característica que aparece nas entrevistas é o fato dessa cozinha ser feminina, ou seja, quem faz as receitas são as mulheres. Nenhum entrevistado falou sobre um avô ou um tio que fazia algo na cozinha. O que aparece também no estudo de Collaço: "era uma cozinha fundamentalmente feminina, uma vez que as mulheres foram as que reproduziram os pratos de suas lembranças, ressaltando seu caráter doméstico." (COLLAÇO, 2012, p.214)

Em algumas entrevistas é possível observar a relação de identidade quando o descendente reproduz as receitas italianas passadas através de ensinamentos da nonna, por exemplo.
A: Ah, eu adorava o Natal, sempre. Gostava, apesar de não ter presentes caros, não ter... Montar árvore, essas brincadeiras. A gente sabia que era um almoço especial. Agora, a coisa mais importante, a comida nunca faltou na mesa. E sempre... aquelas comidas bem... Os grãos, que não era muito comum aqui. Tirando o feijão, as pessoas não tavam acostumadas. Hoje em dia que voltou, né? Você ter a ervilha, a sopa de ervilha... O grão-de-bico.
G: O grão-de-bico, $i$ ceci.
A: I ceci. Nossa, eu não gostava, hoje em dia eu adoro.
G: Exato, a gente aprende.
22'35' A: Porque a gente comia, como é que falava? Nossa, faz tempo que...
G: Vai!
A: A sopa...
G: Il minestrone.
A: Il minestrone. I ceci. Tudo em forma de sopa, ensopado, com músculo...

\footnotetext{
15 Almeida, Silvana Azevedo de, o léxico da cozinha italiana em São Paulo: autenticidade e adaptação nos restaurantes paulistanos. Dissertação (Dissertação em Letras) - USP. São Paulo, p.1-6. 2016.

${ }^{16}$ A palavra "nonna" é muito recorrente nas entrevistas para falar das "avós italianas".
} 
G: $\operatorname{Sim} .{ }^{17}$

A entrevistada traz nomes de pratos e alimentos que continuam presentes em seu cotidiano: "I ceci. Nossa, eu não gostava, hoje em dia eu adoro."

A escolha lexical para relembrar as receitas italianas é feita em italiano. São ingredientes que existem no léxico da língua portuguesa brasileira, mas as entrevistadas fazem questão de utilizar os termos em italiano, para reforçar a cultura italiana, além disso, há a valorização da comida feita para a ceia de Natal, no trecho da entrevista acima.

No quadro abaixo, podemos verificar as ocorrências de palavras que os entrevistados utilizam em italiano na entrevista, mas que existem correspondentes na língua portuguesa.

Quadro 2 - Léxico de alimentos

\begin{tabular}{|l|l|}
\hline Palavras em português brasileiro & Palavras em italiano \\
\hline Grão-de-bico & Ceci \\
\hline Sopa & Minestrone \\
\hline Berinjela & Melanzane \\
\hline Alcachofra & Carciofi \\
\hline Sopa & Brodo \\
\hline Sopa & Minestra \\
\hline Massa & Pasta \\
\hline Abobrinha & Zucchini \\
\hline$\Theta^{18}$ & Zuppa imperiale \\
\hline Caldo & Brodo \\
\hline
\end{tabular}

Fonte: autora

Em outra entrevista, as escolhas lexicais também revelam a forte ligação entre a cultura e a identidade italiana, além dos hábitos diários de alimentação, como a ausência do consumo de arroz e feijão diariamente, que é algo da alimentação brasileira e não italiana:

18'50' N: Então era um itali- era um não era que eu falasse fluentemente mas era um italiano- falava algumas coisas e tinha um italiano passivo num é assim de entender agora provavelmente um italiano que já tinha muitas tranformações que devia ter coisas dialetais porque por exemplo eu sempre-

\footnotetext{
17 As entrevistas foram transcritas de acordo com o método jeffersoniano de transcrição, os detalhes da transcrição estão em: Sacks, Schlegoff \& Jefferson (1974), que é um dos métodos utilizados em estudos de língua falada. As palavras, segundo esse método, são transcritas da forma como são faladas, sem sofrer correções ou alterações.

${ }^{18} \mathrm{O}$ símbolo significa que não há correspondente em português brasileiro.
} 
eu acho que eu já até falei disso pra E. né \# a vi- o léxico e sobretudo o léxico da comida era muito italiano né então a gente comia carciofi a gente não comia

19'24" E: Alcachofra

19'24" N: Alcachofra né mas a gente comia murinhana na minha casa e não como é que é?

19'29" E: Melanzane

19'30" N: Melanzane né \# então era é- zucchini essas coisas né o:: o nome das comidas era:: o nome das verduras das das coisas assim era muito marcado pela influência italiana né então ficou- o tipo de alimentacão também era muito forte \# na minha família num- nós nunca tivemos 0 hábito assim hã:: de comer sei lá o feijão arroz e uma mistura \# feijão e arroz era no dia que se fazia ei lá tinha um dia na semana que se fazia feiião que era:: uma outra comida que se fazia mas no num era assim todo o dia comer feijão com arroz né e:: a coisa da mistura não era mais uma alimentação no estilo italiano muito brodo muita muito caldo sempre sempre tinha- sempre tinha brodo sempre tinha minestra hã todos essas- isso tinha que era era sagrado às vezes mesmo que se comesse outra comida tinha nem que fosse só o caldinho assim tinha e:: a massa feita em casa né os molhos os- enfim as várias comidas italianas [...] gente aprendeu comidas do Vêneto então eu aprendi eu faço um macarrão que eu- ficou batizado na minha casa de macarrão de saco que é- que vai no saco cozido no saco assim que é uma comida vêneta né e:: que depois eu descobri receitas diferentes receitas num é eh:: zuppa imperiale ${ }^{19}$ tem um monte de nomes

Ainda nessa entrevista, é possível observar a tradição das massas caseiras e das receitas que foram passadas para outras gerações, que é o exemplo do "macarrão de saco" que a entrevistada cita que aprendeu a fazer. A escolha de continuar essas receitas revelam uma identidade com a cultura italiana.

Collaço, em seu artigo, define que:

Inspirada no conhecimento das mulheres e fundamentalmente regional, essa cozinha permitiu estabelecer um diálogo entre distintos grupos que partilhavam uma experiência em comum e precisavam se adaptar à nova realidade. Nesse sentido, podemos seguir o caminho sugerido por Douglas (1975) e afirmar que a comida é um dos marcadores de fronteiras étnicas mais potentes, embora longe de ser estável. Comida fala de identidade o tempo todo e se apropria de ideias que circulam em torno de emblemas nacionais e regionais, entre famílias, posição social, idade e que é manipulada a partir de relações sociais. (COLLAÇO, 2012, p. 214-215)

Em algumas entrevistas, os entrevistados revelam que a questão da língua não era tão forte como a questão da comida. Algumas famílias não falavam a língua em casa ou com os filhos, mas a culinária era a italiana e não a brasileira:

\footnotetext{
${ }^{19}$ Sopa típica da Emília-Romanha.
} 
18'52" E: Nem nome de /comida?

18'53"' D: Ah não sim é \# os A. toda assim comida:: costumes eles eram bem italiano mas não puxavam isso daí da da língua em que a:: \# porque na Itália \# eles não eram muito saudosistas eles se adaptaram perfeitamente vamo \# vida nova \# vamo vamo vamo pra frente e pronto né tanto é:: a história do:: imigrante mesmo eles falam <bom agora que virou a página> os $\mathrm{D}$. eram mais\#

A entrevistada mostra como a cultura italiana permaneceu através dos hábitos alimentares: "toda assim comida:: costumes eles eram bem italiano".

No próximo trecho, é possível observar a tradição da cozinha e a valorização do que realmente era "sincero" e de "coração", segundo o entrevistado:

16'19" E: E a comida era italiana?

16'20" J: A comida era italiana ela fazia a massa na casa dela ela fazia todas as coisas que precisava para uma deliciosa macarronada na casa dela mesmo [16'31" E: Uhum] Então é:: sardinha que é uma coisa que nem faz muito parte da alimentação brasileira mas eles trouxeram isso também comer muito peixe \# de modo é:: hã:: quer dizer revisitar essa memória significa pra mim é voltar pra um momento em que as coisas eram mais digamos mais simples mais sinceras mais é \# menos mediadas pelas questões do raciocínio e mais por coisas de coracão né \#

Para o entrevistado, é na simplicidade que ele encontrava a sinceridade da família, são essas memórias que são significativas para ele: "as coisas eram mais digamos mais simples mais sinceras".

Segundo Bauman (2013), a cultura no mundo líquido não é fixa, nem permanente, pois, assim como a identidade, sofre influências de outras culturas, o que acontece em São Paulo com a culinária, conforme já citado. A presença de restaurantes de diversas nacionalidades é reflexo do processo de globalização, pois temos maior acesso aos diferentes tipos de cozinha. Porém, ao escolher fazer as receitas dos seus antepassados, é, além de uma forma de identidade por aquela cultura, um jeito de manter a memória daquela família e suas tradições.

Para Montanari (2009), a comida é a forma mais fácil para se conhecer a cultura do outro, pois não exige muito esforço, diferente de aprender o idioma, por exemplo. Nas entrevistas, por exemplo, a questão da comida é sempre mais aprofundada em relação ao idioma, o que confirma a teoria de Montanari.

É possível observar nas entrevistas, uma tendência a conservação da cultura e identidade italiana quando se fala a respeito de comida. Os entrevistados sempre 
enfatizam a importância para os familiares de manterem os hábitos alimentares italianos, como o consumo de massas, receitas especiais para a família, entre outros.

Em algumas entrevistas, os entrevistados demonstram orgulho quando falam que conseguem reproduzir receitas italianas das avós ou tias. A reprodução das receitas é uma forma de manter vivas as memórias que estão relacionadas àqueles alimentos.

A identidade italiana se confirma no descendente quando ele adota a culinária italiana para sua vida e transmite para as demais pessoas ao redor, confirmando o que Montanari (2009) diz, que as identidades só se formam quando existem as trocas culturais.

\subsection{LÍNGUA, FAMÍLIA E IDENTIDADE}

Esta seção pretende analisar a relação entre a língua italiana, as relações familiares e a identidade. Utilizaremos os estudos de Stuart Hall e Anna Ciliberti para verificar como é a relação dos descendentes com a língua italiana, a ligação entre língua e família e se houve a familiarização desta segunda língua pelos entrevistados.

\subsubsection{A língua italiana nas entrevistas}

Sobre a língua dos imigrantes italianos, é importante chamar atenção para a campanha de nacionalização do governo Vargas (1930-1945) quando os idiomas alemão, italiano e japonês foram proibidos de serem utilizados em público, devido à posição desses países na Segunda Guerra Mundial.

Diante desse cenário, é compreensível o fato de os imigrantes não fazerem esforços para passar a língua italiana para seus filhos e netos, mas demonstrando uma necessidade de aprender a língua portuguesa para que tivessem uma melhor adaptação no Brasil.

Franco Cenni, em seu estudo sobre os imigrantes italianos no Brasil, traz questões importantes para pensarmos a relação dos italianos com a língua, quando comparados aos outros imigrantes que vieram em massa para o país: 
O recenseamento de 1940 incluiu em seus boletins as perguntas individuais: "Fala corretamente o português?" e "Que língua fala habitualmente no lar?". Os resultados, a julgar pela escrupulosidade da maioria das respostas, devem ser considerados fidedignos. Entre os 231138 italianos presentes àquela época no estado de São Paulo, os que não falavam corretamente o português seriam apenas 18445 , isto é, 8,7\%, enquanto entre os 394363 elementos de outros países estrangeiros (excluindo-se Portugal, por razões óbvias) os que não falavam corretamente o português eram 94747 , isto é, $24,0 \%$.

As proporções dos que falavam outra língua no lar geralmente eram maiores do que as dos que não usavam corretamente o português, pelo fato evidente de que muitos imigrados usam a língua portuguesa fora do lar, em suas relações com os nacionais ou com outros estrangeiros, enquanto no lar continuam falando a língua do país de origem. Mas, também nesse caso, dos 213138 italianos presentes no estado, somente 28910 , ou seja, 13,6\%, falavam sua língua no lar, enquanto para as outras nacionalidades (sempre com exclusão dos portugueses) tal porcentagem subia a 49,1\%. (CENNI, 2011, p. 328-329)

No nosso roteiro utilizado nas entrevistas tem a pergunta "e que língua se fala(va) na sua casa? Alguém ainda fala italiano? Você já ouviu alguém falando italiano?" e as respostas sofrem variações. Alguns entrevistados dizem que a família falava italiano em casa, outros dizem que os familiares falavam apenas a língua portuguesa. Os motivos por não falarem italiano são diversos também, ora é por não se orgulhar da língua italiana, ora era uma língua que devia ser escondida devido às opressões do governo ou, em outros casos, uma língua para assuntos "secretos":

E: Entendi. E alguém falava italiano?

$\mathrm{J}$ : O nonno falava italiano e falava italiano com os filhos. É na verdade...

$\mathrm{E}:$ O nonno L.?

$\mathrm{J}$ : O nonno L. que foi o que eu conheci melhor.

E: Sim.

J: Porque o outro é... o... o... o pai da minha mãe já não falava italiano porque a mãe da minha mãe não era italiana.

E: Sim

J: E então eles já não falavam italiano mas o nonno L. sim... falava italiano... um dialeto Vêneto... e... e... e eles conversavam entre eles em italiano principalmente quando era pras crianças não saberem do que se falava... aí eles falavam italiano... era uma língua secreta.

O entrevistado acima fala que o italiano não era uma língua utilizada de qualquer forma, havia um mistério ao redor da língua: “era uma língua secreta.”, sendo assim, não foi uma língua difundida entre as gerações posteriores.

No trecho abaixo, outra entrevistada fala que a avó evitava falar italiano:

E. E alguém falava italiano?

A. Então, a minha mãe conta pra nós que a minha avó evitava falar o italiano, era uma coisa que parece que não era muito de orgulho falar o italiano, porém, a minha mãe até hoje solta expressões, até umas que eu nunca ouvi em dialeto né que vem dessa parte norte da Itália 
Nesta entrevista, ela afirma que a língua italiana não era causa de orgulho para a família: "a minha avó evitava falar o italiano, era uma coisa que parece que não era muito de orgulho".

Dos dez entrevistados, apenas quatro dizem que falam a língua italiana, porém, ao longo da entrevista, oito entrevistados falam palavras de origem italiana. A escolha por utilizar a língua italiana para falar algumas palavras que existem a tradução na língua portuguesa, também é um ponto fundamental para verificar a construção de uma identidade italiana no entrevistado. Segundo Anna Ciliberti, "a escolha de um idioma e não de outro repertório constitui, portanto, um elemento altamente significativo na construção de identidades sociais, étnicas e culturais." ${ }^{20}$ (CILIBERTI, 2007, p.22) (Tradução nossa).

Quando o entrevistado usa termos ou expressões em italiano, ele reforça sua identidade cultural com o idioma e demonstra uma preocupação em manter aquela tradição da língua, principalmente quando é para falar sobre os membros da família, como nonna e nonno 21 :

J: E... é... com muita frequência se rezava o terço em família. E o nonno... pai do meu pai... é... rezava uma... pra São Sebastião... São Roque e São não sei quem... que não me lembro o outro... que nos livre da peste... da fome e da guerra... como ele dizia. Bom... e eu imagino que isso... como isso não é da experiência brasileira... de ninguém... nem a peste... nem a fome e nem a guerra... eu imagino que deveria ser a experiência deles na Itália... e embora não se falasse disso... é... com frequência... não se contasse histórias da Itália... porque... a verdade é que meu avô muito pequeninho da Itália... ele tinha 6 anos de idade... é esse o meu avô com quem eu convivi mais. A minha avó... mãe do meu pai... eu não conheci a nonna... ela teve um AVC e ficou durante muitos anos paralítica e- é... e daí eles- é... ela tinha morrido antes de minha mãe se casar com meu pai... portanto eu não a conheci... e o nonno que eu conheci que é o nonno L. que é o pai do meu pai, esse embora não falasse nisso, essa experiência da Itália, pra mim tava presente em orações que se faziam, etc. e isso era muito recorrente, né.

O entrevistado sempre se refere aos avós como nonna e nonno, evidenciando uma identidade cultural italiana, pois mantém a língua italiana presente, mesmo que indiretamente. Este hábito italiano aparece em outras entrevistas, no trecho abaixo, a

\footnotetext{
20 "La scelta di una lingua piuttosto che di un'altra del proprio repertorio costituisce dunque un elemento altamente significativo nella costruzione di identità sociali, etniche, culturali" (CILIBERTI, 2007, p.22)

${ }^{21}$ Avó e avô, respectivamente.
} 
entrevistada também se refere à família da sua nonna, evitando usar a palavra "avó" em língua portuguesa:

03'47" N: \# Bom a família- hã- no caso da família da minha nonna eles diziam que eram que vieram por necessidades mesmo né e ou seja poucas oportunidades de trabalho lá e vinham em busca da América sem dúvida nenhuma \# [...]

No trecho abaixo, outra entrevistada enfatiza que a língua italiana é apenas ela quem fala, os outros familiares falavam uma mistura de português com dialeto:

15'24" S: E que língua se falava na sua casa é::: alguém ainda fala italiano? 15'30" D: Eu sou a única que fala de verdade que fala italiano na casa sempre foi um \# sempre se falou português ele falava português hã::: muitas palavras do- do dialeto dele né da cidadezinha dele mas ninguém hã::: o italiano não foi \# não foi repassado e eu acho que é uma coisa até bastante comum na época das pessoas não não repassar como a gente pode dizer \# tramandare

A entrevistada traz essa questão do dialeto: "muitas palavras do- do dialeto dele", traz outra questão importante, o fato de muitos italianos falarem apenas o dialeto e não o italiano "standard", devido às questões de unificação tardia italiana. Muitas vezes, havia a dificuldade na comunicação entre os italianos devido às diferenças dos dialetos.

Segundo Cenni, no período da grande imigração existiu uma dificuldade na propagação da língua italiana, porque os imigrantes sabiam apenas seus dialetos. Ele cita Enrico Ferri:

[...] Os italianos da América do Sul aprendem e falam mais facilmente o espanhol e o português do que o italiano. Por quê? Porque os italianos que para lá emigram falam seus dialetos. Por exemplo: um piemontês, jovem ou adulto, que chega no Brasil tem quase o mesmo trabalho para aprender o italiano ou o português, e então procura aprender o português antes do que o italiano. (FERRI, 1909 apud CENNI, 2011, p.323) 


\subsubsection{A língua como condutora de identidades e memórias}

Neste subitem apresentaremos as ocorrências das palavras mais utilizadas nas entrevistas e a relação com a italianidade.

\subsubsection{Ocorrências}

Ao analisar as entrevistas é possível observar que algumas palavras foram utilizadas por todos os entrevistados, o que nos levou a verificar a sua frequência em cada entrevista.

Os quadros abaixo são separados pelas categorias: cozinha, língua e família, escolhidas por representarem os temas mais recorrentes nas entrevistas, devido ao roteiro utilizado.

Quadro 3 - Ocorrências de palavras relacionadas à cozinha

\begin{tabular}{|c|c|c|c|c|c|c|c|c|c|c|c|}
\hline \multicolumn{12}{|c|}{ COZINHA } \\
\hline \multirow{2}{*}{ PALAVRA } & \multicolumn{11}{|c|}{ ENTREVISTA } \\
\hline & 1 & 2 & 3 & 4 & 5 & 6 & 7 & 8 & 9 & 10 & TOTAL \\
\hline Alimento & 0 & 0 & 0 & 0 & 0 & 0 & 0 & 0 & 0 & 2 & 2 \\
\hline Alimentação & 0 & 1 & 0 & 0 & 1 & 0 & 1 & 2 & 0 & 0 & 5 \\
\hline Almoço & 0 & 1 & 0 & 4 & 2 & 1 & 0 & 0 & 0 & 1 & 9 \\
\hline Arroz e feijão & 0 & 1 & 0 & 0 & 0 & 0 & 2 & 3 & 0 & 1 & 7 \\
\hline Comer & 1 & 0 & 0 & 0 & 2 & 0 & 2 & 3 & 1 & 0 & 9 \\
\hline Comida & 1 & 3 & 3 & 1 & 1 & 1 & 1 & 10 & 2 & 1 & 24 \\
\hline Cozinha & 0 & 1 & 0 & 0 & 0 & 0 & 0 & 0 & 1 & 0 & 2 \\
\hline Cozinhar/ cozinhava/cozinhavam & 1 & 0 & 2 & 0 & 0 & 0 & 0 & 0 & 0 & 0 & 3 \\
\hline Jantar & 0 & 0 & 0 & 0 & 0 & 0 & 0 & 0 & 1 & 1 & 2 \\
\hline Macarrão & 0 & 2 & 0 & 0 & 1 & 0 & 0 & 2 & 1 & 1 & 7 \\
\hline Pratos & 0 & 0 & 0 & 0 & 0 & 0 & 1 & 0 & 1 & 0 & 2 \\
\hline Vinho & 0 & 0 & 0 & 5 & 0 & 0 & 0 & 0 & 0 & 22 & 27 \\
\hline
\end{tabular}

Fonte: autora 
Quadro 4 - Ocorrências de palavras relacionadas à língua

\begin{tabular}{|l|c|c|c|c|c|c|c|c|c|c|c|}
\hline \multicolumn{10}{|c|}{ PALAVRA } & \multicolumn{7}{|c|}{ ENTREVISTA } \\
\cline { 2 - 14 } & $\mathbf{1}$ & $\mathbf{2}$ & $\mathbf{3}$ & $\mathbf{4}$ & $\mathbf{5}$ & $\mathbf{6}$ & $\mathbf{7}$ & $\mathbf{8}$ & $\mathbf{9}$ & $\mathbf{1 0}$ & TOTAL \\
\hline Cidadania & 0 & 0 & 0 & 1 & 0 & 2 & 1 & 0 & 2 & 0 & $\mathbf{6}$ \\
\hline Conversar/conversava/conversavam & 0 & 0 & 0 & 0 & 0 & 2 & 0 & 0 & 1 & 0 & $\mathbf{3}$ \\
\hline Dialeto & 4 & 4 & 6 & 0 & 1 & 2 & 2 & 0 & 0 & 0 & $\mathbf{1 9}$ \\
\hline Falar/falava/falavam & 14 & 25 & 16 & 2 & 6 & 15 & 14 & 23 & 36 & 18 & $\mathbf{1 6 9}$ \\
\hline Falar italiano & 0 & 2 & 12 & 0 & 0 & 2 & 0 & 3 & 3 & 1 & $\mathbf{2 3}$ \\
\hline Idioma & 0 & 0 & 0 & 0 & 0 & 0 & 1 & 0 & 0 & 0 & $\mathbf{1}$ \\
\hline Itália & 7 & 12 & 16 & 8 & 7 & 14 & 6 & 17 & 23 & 18 & $\mathbf{1 2 8}$ \\
\hline Italiano (idioma) & 9 & 46 & 14 & 5 & 7 & 18 & 10 & 17 & 8 & 5 & 139 \\
\hline Língua & 6 & 13 & 2 & 2 & 0 & 5 & 7 & 2 & 0 & 6 & $\mathbf{4 3}$ \\
\hline Língua proibida & 0 & 0 & 0 & 0 & 0 & 0 & 0 & 1 & 0 & 0 & $\mathbf{1}$ \\
\hline País & 0 & 0 & 1 & 0 & 1 & 0 & 6 & 0 & 1 & 1 & $\mathbf{1 0}$ \\
\hline Paese & 0 & 0 & 0 & 3 & 0 & 0 & 1 & 0 & 0 & 0 & $\mathbf{4}$ \\
\hline
\end{tabular}

Fonte: autora

Quadro 5 - Ocorrências de palavras relacionadas à família

\begin{tabular}{|c|c|c|c|c|c|c|c|c|c|c|c|}
\hline \multicolumn{12}{|c|}{ FAMÍLIA } \\
\hline \multirow{2}{*}{ PALAVRA } & \multicolumn{11}{|c|}{ ENTREVISTA } \\
\hline & 1 & 2 & 3 & 4 & 5 & 6 & 7 & 8 & 9 & 10 & TOTAL \\
\hline Costumes & 0 & 0 & 0 & 1 & 0 & 0 & 2 & 1 & 1 & 0 & 5 \\
\hline Família & 12 & 9 & 37 & 20 & 33 & 5 & 16 & 57 & 15 & 6 & 210 \\
\hline Hábitos & 0 & 0 & 0 & 0 & 2 & 1 & 0 & 1 & 3 & 0 & 7 \\
\hline Irmão & 1 & 5 & 0 & 2 & 3 & 1 & 8 & 7 & 7 & 1 & 35 \\
\hline Mamma mia & 1 & 0 & 0 & 0 & 0 & 0 & 0 & 0 & 0 & 0 & 1 \\
\hline Nonno & 0 & 0 & 0 & 0 & 0 & 9 & 2 & 1 & 0 & 0 & 12 \\
\hline Nonna & 0 & 0 & 0 & 0 & 0 & 1 & 0 & 17 & 0 & 0 & 18 \\
\hline Parentes & 0 & 1 & 0 & 1 & 1 & 0 & 0 & 0 & 0 & 2 & 5 \\
\hline
\end{tabular}

Fonte: autora

Nas figuras abaixo, podemos observar as palavras mais utilizadas nas entrevistas: 
Figura 1 - Ocorrências de palavras da categoria "comida" nas entrevistas

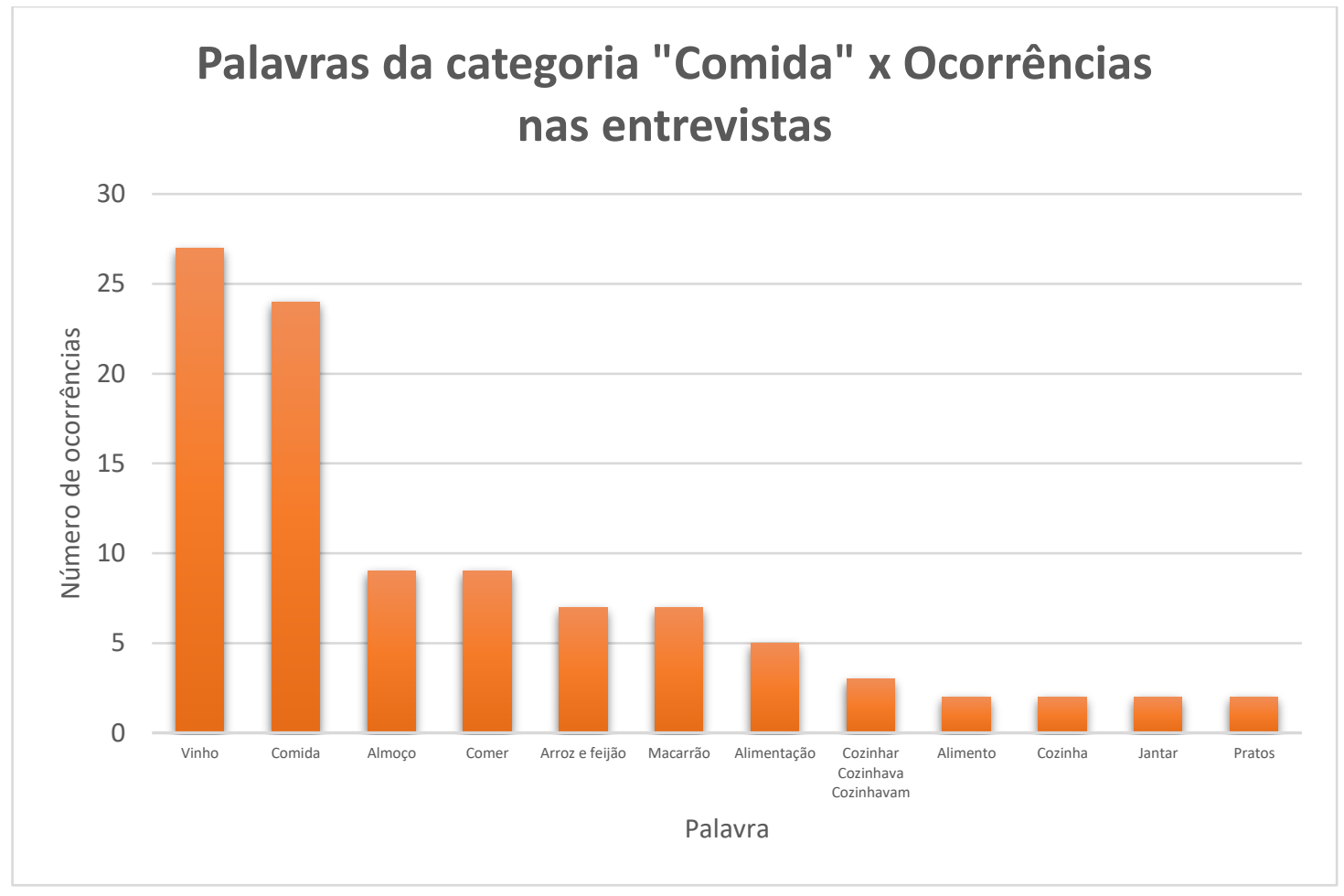

Fonte: autora

Na figura acima é possível observar que "vinho" foi a palavra mais utilizada nas entrevistas dentro do campo lexical de "cozinha", sendo utilizada 27 vezes. A segunda palavra mais utilizada é "comida", com 24 usos.

Podemos observar que a palavra "almoço" aparece 9 vezes nas entrevistas, demonstrando um hábito italiano citado nas entrevistas. Reunir a família em almoços fartos no domingo ou em datas festivas. Enquanto a palavra "jantar" aparece apenas 2 vezes, sem remeter a possíveis costumes "italianos".

Em relação aos nomes dos pratos, "macarrão" é uma palavra utilizada 7 vezes, reforçando a ligação dos italianos com a massa. A repetição de "arroz e feijão" é igual, 7 vezes, porém, quando analisamos o contexto, percebemos que os entrevistados explicam que os familiares não tinham o hábito de comer a típica comida brasileira.

O termo "alimentação" aparece 5 vezes, usado por alguns entrevistados para falar sobre os hábitos da família. Não tem um uso muito frequente nas entrevistas, pois os costumes e a forma de alimentação aparecem de forma mais indireta com o uso de palavras já citadas, como "macarrão" e "almoço". 
Na próxima figura, temos o campo lexical "língua" e as palavras mais utilizadas nas dez entrevistas analisadas, o verbo "falar" e suas conjugações foram utilizados 169 vezes pelos entrevistados. A palavra "italiano" para se referir ao idioma aparece 139 vezes ao longo das entrevistas. Observamos que a palavra "língua" que poderia ser mais utilizada, não aparece com tanta frequência nas falas dos entrevistados. $O$ termo "idioma" aparece uma única vez, talvez por ser uma palavra mais formal, é a menos usada. A palavra "Itália" é falada 128 vezes, reforçando a relação dos entrevistados com o país europeu.

Figura 2 - Ocorrências de palavras da categoria "língua" nas entrevistas

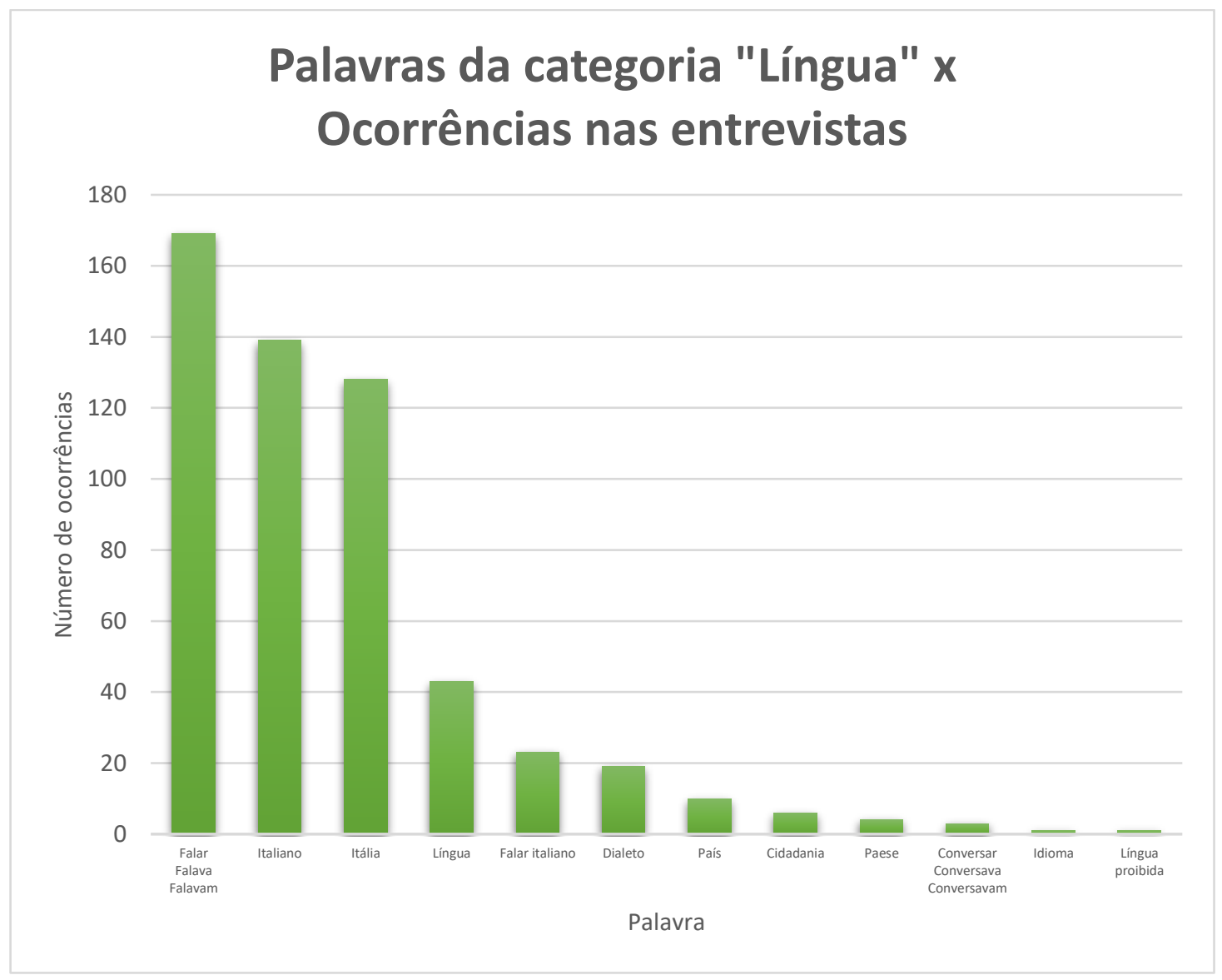

Fonte: autora

Na figura abaixo, podemos observar as palavras ligadas à "família": 
Figura 3 - Ocorrências de palavras da categoria "família" nas entrevistas

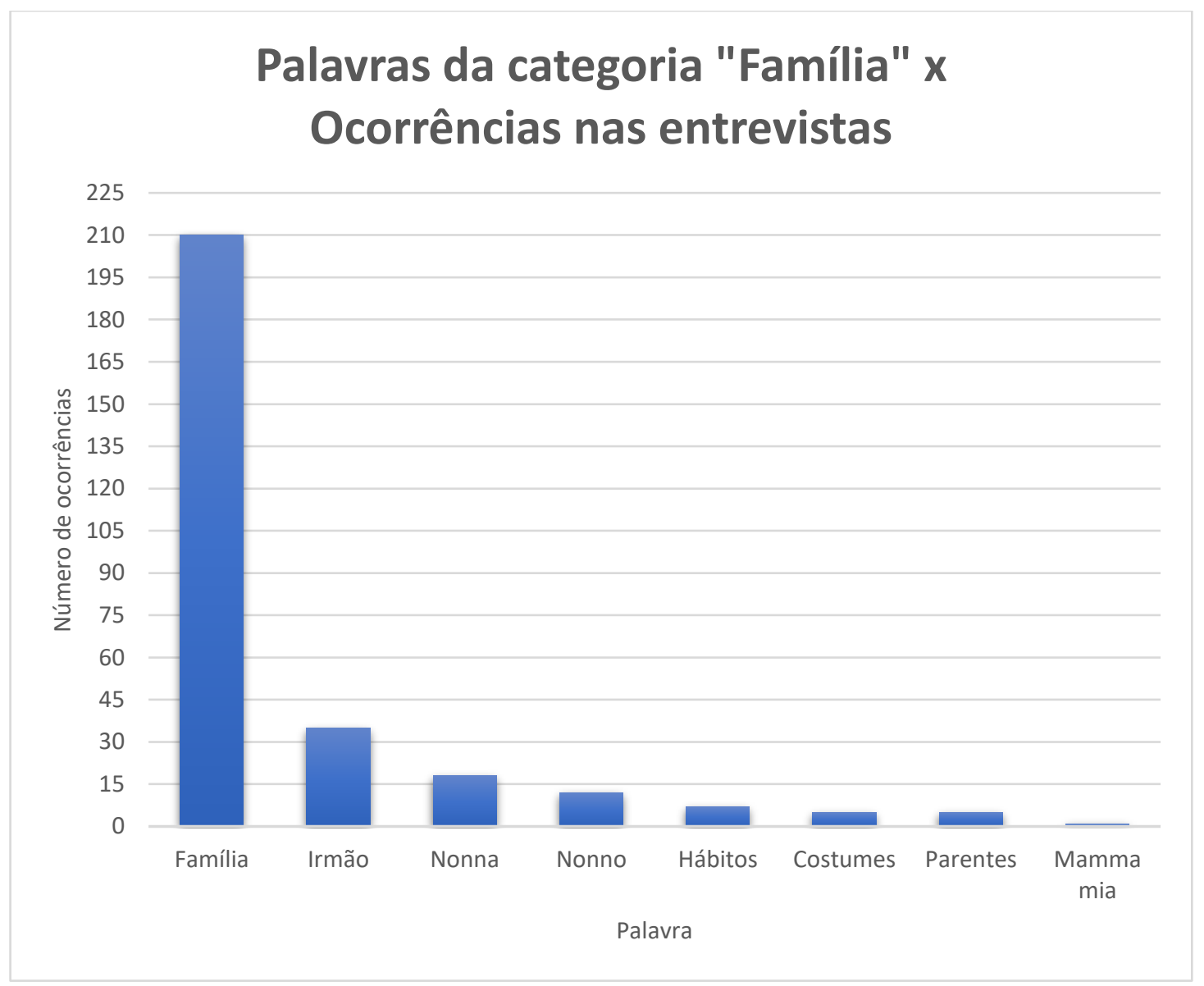

Fonte: autora

A palavra "família" aparece 210 vezes nas falas dos entrevistados, reforçando a ligação dos entrevistados com a família. Palavras como "nonno" e "nonna" aparecem frequentemente, demonstrando que os entrevistados optam por utilizar as palavras em italiano para se referirem aos avós italianos, evidenciando um laço afetivo com a língua.

As palavras "hábitos" e "costumes" não aparecem frequentemente na fala dos entrevistados, mas ao longo das entrevistas eles contam sobre os hábitos e costumes da família. Alguns entrevistados explicam que mantém alguns desses hábitos, a tradição dos almoços de domingo, por exemplo.

Dessa forma, passamos às considerações finais deste trabalho. 


\section{CONSIDERAÇÕES FINAIS}

Esta pesquisa teve por objetivo estudar a construção da identidade italiana em descendentes através das narrativas das entrevistas. Os entrevistados são de São Paulo, netos, filhos e bisnetos de italianos, grande parte são professores da USP. Considerei importante investigar a vinda dos italianos para o Brasil, observei os principais picos de imigração italiana para o maior país da América Latina, segui as pesquisas de Franco Cenni (2011), Angelo Trento (1989) e Herbert S. Klein (1989). número de italianos que veio para o Brasil foi muito significativo, principalmente no Estado de São Paulo, o que motivou diversas pesquisas sobre os italianos e os descendentes.

A coleta de entrevistas com os descendentes de italianos trouxe um material rico de informações sobre as famílias, os costumes e as tradições que se mantiveram ou que se perderam ao longo dos anos. Ao ouvir as narrativas gravadas, pude observar traços identitários presentes nos entrevistados, identidades fragmentadas, múltiplas, e segundo Hall (2019) e Bauman (2005), percebi que a identidade dos entrevistados oscila entre a Itália e o Brasil.

Identidades que são múltiplas, pois os entrevistados são descendentes, ou seja, são pessoas que nasceram, cresceram e moram no Brasil, falam a língua portuguesa brasileira e não negam o seu lado brasileiro, mas ao mesmo tempo, pela família ser de origem italiana, assumem seus traços culturais, suas identidades através da alimentação, das conservações das histórias familiares, pelo estudo da língua italiana, além de outras afinidades com a Itália.

A memória dos entrevistados é construída pelas narrativas familiares, histórias que foram passadas entre as gerações, além da memória coletiva da sociedade. Alguns pontos narrados pelos entrevistados se mesclam com as histórias já conhecidas sobre os italianos, por exemplo, a proibição da língua italiana durante o governo Vargas. A conservação da memória também é uma característica da identidade, só mantemos em nossa memória aquilo que faz parte da nossa história, o que faz parte do nosso "eu".

A cozinha italiana também tem papel importante na alimentação dos descendentes, alguns entrevistados mantém as tradições italianas na cozinha, como 
a execução de pratos de família e almoços de domingo. Ao manter esses costumes culinários e repassando para outras gerações, o entrevistado reforça sua identidade italiana.

Ademais, a língua italiana tem um papel fundamental na construção da identidade italiana dos entrevistados, até mesmo aqueles que não falam o idioma mantêm uma relação afetiva com a língua ao falar da família, de músicas, das tradições, dos objetos, dos alimentos, utilizando um vocabulário de palavras italianas, como "nonno", "melanzane", entre outras observadas nesta pesquisa.

Ao longo das análises é possível observar como a língua italiana é a condutora das memórias e das identidades dos entrevistados, já que muitos utilizam a língua para narrar algumas de suas histórias ou foram estudar a língua por ter uma ligação afetiva com o idioma italiano. A ocorrência da palavra "italiano" como idioma é muito significativa nas entrevistas, mesmo quando há uma negativa na resposta da pergunta relacionada à língua, os entrevistados sempre ressaltam a sua importância e a "beleza" do idioma europeu.

A identidade italiana dos entrevistados é marcada também quando revelam com orgulho a origem da família. Notamos que a repetição da palavra "família" nas entrevistas explicitou a forte relação existente entre os entrevistados e as histórias familiares narradas. Os entrevistados ficam emocionados, orgulhosos e sentem-se importantes ao contar os acontecimentos e as trajetórias familiares. Dessa forma, eles ressaltam as dificuldades dos imigrantes italianos e destacam as superações vividas por eles.

As histórias narradas nas entrevistas trazem muitos pontos que confirmam os estudos de imigração italiana, como a maior quantidade de imigrantes da região norte da Itália, a precariedade que os italianos encontraram ao chegar no Brasil, os trabalhos em lavouras e fazendas de café, a falta de apoio do governo brasileiro, a proibição da língua italiana, entre outras.

Os gráficos das palavras nos mostraram que a ocorrência de algumas palavras é muito maior que outras, como no caso da repetição da palavra "família" que aparece 210 vezes ao longo das entrevistas e como a presença da palavra "italiano" para se referir a língua italiana também é expressiva, aparecendo 139 vezes. Em 
contrapartida, outras palavras não foram muito utilizadas, como "idioma", que talvez por ser uma palavra mais formal, não foi a escolhida para falar sobre a língua.

Acreditamos, assim, que este trabalho possa contribuir para a compreensão de como a presença italiana se manifesta nos descendentes de italianos e estimular a continuidade dos estudos nesse âmbito. Pesquisas futuras podem ser realizadas utilizando as transcrições das entrevistas para verificar outros tipos de ocorrências, ou ainda a análise da conversação, análise lexical ou análise do discurso. Além das transcrições, os vídeos das entrevistas trazem outras marcas que também podem auxiliar possíveis estudos. O crescimento dos estudos de História Oral favorece pesquisas desse tipo. 


\section{REFERÊNCIAS}

ALMEIDA, Silvana Azevedo de. O léxico da cozinha italiana em São Paulo: autenticidade e adaptação nos restaurantes paulistanos. Dissertação (Dissertação em Letras) - USP. São Paulo, p.1-6. 2016.

BARAUSSE, Alberto; LUCHESE, Terciane Ângela (2017). Da Itália ao Brasil: processos educativos e formativos, séculos 19 e 20. Hist. Educ., Santa Maria, v.21, n. 51, p. 33-40, Apr. 2017. https://doi.org/10.1590/2236-3459/68983.

BAUMAN, Zigmunt. Identidade: entrevista a Benedetto Vecchi. Tradução: Carlos Alberto Medeiros. Rio de Janeiro: Zahar, 2005.

BILIA, M. (1997). L'italiano parlato a San Paolo: un corpus per future ricerche. Revista De Italianística, 5(5), 23-27. https://doi.org/10.11606/issn.2238-8281.v5i5p2327.

BORGES, Jorge Luis. Poesia. Tradução Josely Baptista. São Paulo: Companhia das Letras, 2009.

CAPRARA, Loredana (2000). O Italiano dos Italianos em São Paulo. Introdução. Revista de Italianística vol 5. pp. 9-15.

CAPRARA, Loredana (2003). L'italiano degli italiani di San Paolo alla fine Del XX secolo. In: Italiano e Italiani Fuori d'Italia a cura di Anna de Fina e Franca Bizzoni. Peruggia, Guerra. pp.199-216.

CAPRARA, Loredana. MORDENTE, Olga Alexandra (2004). Panorama dell'italiano in San Paolo nel contesto plurilinguistico brasiliano. Revista de Italianística IX pp.101-111.

CASTRO, Giliola Maggio de. Pedrinhas Paulista: Memória e Invenção. Tese (Doutorado em Geografia) - Universidade de São Paulo, São Paulo, 2002.

CATARRULLA, Camilla (org.). Identità culinarie in Sudamerica. Nova Delphi Libri S.r.I., Roma, 2017.

CENNI, Franco. Italianos no Brasil. 3ạ edição, 1. reimpr. - São Paulo: Editora da Universidade de São Paulo, 2011.

DE FINA, Anna in CILIBERTI, Anna (org). La costruzione interazionale di identità: repertori linguistici e pratiche discorsive degli italiani in Australia. Materiali Linguistici Università di Pavia: FrancoAngeli s.r.l., Milano, Italy, 2007.

COLLAÇO, Janine Helfst Leicht. Imigração e cozinha italiana na cidade de São Paulo, Anuário Antropológico [Online], I | 2012, posto online no dia 01 outubro 2013, consultado no dia 15 novembro 2019. http://journals.openedition.org/aa/327.

HALBWACHS, Maurice. A memória coletiva. Tradução de Beatriz Sidou - São Paulo, SP: Centauro, 2003. 
HALL, Stuart. A identidade cultural na pós-modernidade. Tradução Tomaz Tadeu da Silva \& Guaracira Lopes Louro - 12 ed., 2ª reimpressão - Rio de Janeiro: Lamparina, 2019.

KLEIN, H. S. A integração dos imigrantes italianos no Brasil, na Argentina e Estados Unidos. Novos estudos. CEBRAP, n. 25, p. 95-117, 1989.

MEIHY, José Carlos Sebe Bom. Manual de História Oral. Edições Loyola, São Paulo, 1996.

MEIHY, José Carlos Sebe Bom; RIBEIRO, Suzana Lopes Salgado. Guia Prático da História Oral: para empresas, universidades, comunidades, famílias. Editora Contexto, São Paulo, 2011.

MONTANARI, Massimo (org.). 0 mundo na cozinha: história, identidade, trocas. Tradução Valéria Pereira da Silva. - São Paulo: Estação Liberdade: Senac, 2009.

RICOEUR, Paul. A memória, a história, o esquecimento. Tradução: Alain François. Editora da UNICAMP, 2007.

SACKS, H.; SCHLEGOFF, E.A., JEFFERSON, G. (1974). A simplest systematics for the organization of Turn-taking for conversation. Language, vol. 50, n.4, part 1, p.696-735.

TRENTO, Angelo. Do outro lado do Atlântico: Um século de Imigração Italiana no Brasil. Tradução: Mariarosaria Fabris (capítulos 2 a 5), Luiz Eduardo de Lima Brandão (capítulos 1, 6 e 7). Livraria Nobel, São Paulo, 1989. 


\section{APÊNDICE A - Transcrição da entrevista 01}

E. A., você sabe como a sua família veio ao Brasil? Eles te contaram alguma coisa? 14" A. então, é uma memória que fica com pouco perdida, então você precisa ficar procurando por perguntas, perguntando pros mais velhos. O que eu sei é que eles vieram de navio né, os meus bisavós vieram de navio pro Brasil, na segunda metade do século XIX. A parte paterna da minha família foi pro interior do estado de São Paulo, então ali perto de Rio Claro se instalaram por ali e trabalhando em fazenda né? O meu avô, então sobre o pai do meu avô que se chamava F. Z. eu não tenho muita informação mas eu sei que ele trabalhava sim em fazendas de café, vieram trabalhar com isso e o meu avô ele desde de muito novo ele queria subir na vida sair daquele lugar e começou a fazer vários trabalhos aqui, ele fez vários trabalhos caixeiro viajante, trabalhou em fazenda como capataz e tal. Só que ele foi, ele era...tinha uma visão inteligente o bastante né pra esquematizar o futuro dele, e fazendo isso ele conseguiu fazer uma torrefação de café.

E. a foi Café?

A. é café!

E. esse é o Z.? O F.?

01'43"' A. o F. era o bisavô, esse é meu avô S. Z.

E. Ah, S. Com nome é melhor porque a gente organiza as famílias.

01'52" A. Esse é o avô paterno. Então ele chegou e elaborou essa torrefação na frente da casa dele que também era uma casa boa pra época né e comprou algumas terrinhas né, tinha então essa chácara e tal em São Carlos, mas o grosso do café claro vinha de outras fazendas, mas aí também essa chácara foi...ele junto com o meu pai que é o H., eles fizera uma beneficiadora de café, então eles compravam o café cru e beneficiavam esse café lá nessa chácara e depois torravam esse café na torrefação que já era um prédio dentro da cidade, da cidade hoje porque cresceu né, mas era um bairro não tão desenvolvido na época.

E. Acho que essa torrefação ainda faltava entre as possíveis coisas, porque tem que fez o armazém né, mas a torrefação não tinha ainda. Legal. E...

02'56" A. E tem a parte da minha mãe, não sei se você quer saber, mas da parte da minha mãe é a mesma coisa. A notícia que eu tenho dos bisavós que vieram pra cá junto já com o meu avô já nascido, então o meu avô já era nascido é na Itália da família P.. Os Z. vieram da Calábria e a P. de Udine então foi o norte com o sul. A minha avó 
que era T. falava pras filhas "não casem com calabresi" mas a minha mãe casou com um, descendente né. Então esse meu avô que se chamava A. P., ele era italiano, já veio nascido mas pequeno e veio pequeno pra cá e trabalhava com carpintaria, ele era carpinteiro né e marceneiro

04'01' E. Isso na mesma época também?

A. É na mesma época né, eles têm mais ou menos a mesma idade. Acho que a minha avó era um pouco...eles eram um pouco mais velhos... os paternos um pouco mais velhos que os maternos. Então esse meu avô o A. P. ele trabalhou com isso, com carpintaria e com marcenaria, então ele fazia...ele trabalhava com madeira, então ele desenhava muito bem, então foram guardados os cadernos dele, os desenhos que ele fazia pra desenhar a madeira né, pra esculpir mesmo a madeira né.

E. Mas essa profissão ele aprendeu aqui, ou era de família?

04'37' A. Ele aprendeu...ele trouxe da família, era uma coisa de família e ele trouxe...resolveu trabalhar com isso e trabalhou com isso a vida dele que foi curta porque minha mãe tinha quatro anos quando ele morreu.

E. Ah tá, então você também só ouviu falar dele?

A. Sim, só ouvi falar desse avô, só ele que eu não conheci, os outros eu conheci todos.

04'58' E. E os seu avós, os seus pais, contavam alguma história que ainda era da época que se vivia na Itália? Alguma coisa que se fazia lá, alguma tradição?

A. Não contavam nada, nada, nada, nada, toda tradição vivida lá e trazida pra cá de alguma maneira, a gente vivenciou indiretamente, então na maneira de ser das pessoas, na maneira de cozinhar, na maneira de se portar em casa, na maneira de organizar as coisas, então a gente recebeu isso mas indiretamente.

E. Nunca ninguém falou isso?

05'36' A. Nunca foi explícito.

E. E depois assim vocês conseguiram reconhecer, perceber diferenças o que era ser de uma família italiana em relação a outras pessoas de outras origens, de outras nacionalidades?

05'51' A. Então em São Carlos que foi a cidade onde eu nasci hã... era um pouco difícil isso porque era uma cidade basicamente formada por descendentes de italianos, como todo aquele pedaço ali do estado de São Paulo, eu não sei vocês que tão fazendo esse mapeamento vocês saibam mais sobre isso mas ali, as minhas amizades, as famílias que eu frequentava todos eram descendentes de italianos.

06'18'” E. Então não dava para perceber a diferença? 
A. Não dava pra fazer essa diferenciação

06'23' E. Em casa nunca se falava alguma coisa sobre o ser italiano, como era ser italiano no Brasil?

A. Sim, o meu pai sempre teve muito orgulho, ele dizia que ele era italiano quando tinha copa do mundo por exemplo a gente torcia pela Itália também, sempre foi assim em casa, então essa coisa do ser italiano foi algo que a gente trouxe bem forte, mas não por uma questão explícita de trazer a origens de contar a histórias, nada disso, era uma coisa do sangue vamos dizer assim, tava já dito que todo mundo ali era italiano e tinha que torcer pro time da Itália e pronto.

07'00' E. Não se discutia isso?

A. Não

E. E tinha alguma coisa de que $o$ italianos, já que eram todos italianos faziam entre eles? Festas, assim alguma coisa de italianos ou lugares onde eles se encontravam, coisas desse tipo?

07'14" A. Não, o que eu me lembro da família do meu pai que houve uma ou duas vezes uma grande festa pra reunir todos os familiares em Ribeirão Bonito, que é uma cidade muito pequenininha ali mas onde também meu avô paterno morou, então vários familiares mora lá e tal, e da parte da minha mãe também eram festas grandes nas quais a gente reunia todos os familiares em volta da matriarca que era a minha avó, tanto que quando ela faleceu essa coisa foi se perdendo né um pouco, tinha isso. 07'48' E. E alguém falava italiano?

A. Então, a minha mãe conta pra nós que a minha avó evitava falar o italiano, era uma coisa que parece que não era muito de orgulho falar o italiano, porém, a minha mãe até hoje solta expressões, até umas que eu nunca ouvi em dialeto né que vem dessa parte norte da Itália, algumas a gente dizia quando era criança, todo mundo na família todos os primos, que é uma família bem grande, acho que só de primo deve ter uns quarenta, quarenta e cinco só de primos

E. Tem que chamar todos pra cá...fazer entrevista...(risos)

A. E aí eles já reproduziram né já tem suas famílias cada um com três, quatro, dois, um filho, magina.

E. Então festa de todo mundo já não dá mais

A. A gente já fez. A gente fez recentemente uma, foi bem interessante!

E. Tem que alugar um lugar?

A. Tem que alugar um lugar. Uma chácara... 
E. Eh...

08'52'A. Tem que alugar pra caber todo mundo. É então essas coisas que eram ditas, a gente achava que era português...

E. Ah, olha... quando criança?

08'57'A. Vou dar um exemplo bem simples o cent'anni então a gente falava assim "faz cent'anni" e falava cent'anni, falava desse jeito, faz cent'anni que eu não faço isso, como se fosse português, eu não sabia que não era o português, fui saber quando a minha irmã entrou na universidade a C. que você conhece, foi estudar o italiano e falou gente cent'anni é italiano, ah achei que fosse português (risos) então tem várias coisas assim que a gente descobriu depois que era italiano

09'33" E. nunca aconteceu de falar isso com outras pessoas e as pessoas não entenderem?

A. Não, passava porque no contexto né, mas com a minha mãe é interessante, porque até hoje ela solta essas expressões e coisa e tal e a gente fala assim, o que que quer dizer mãe? ela não sabe, só sabe usar na situação.

E. Ela não sabe traduzir?

09'52' A. Não sabe traduzir ao pé da letra o que é cada elemento, não sabe nada disso, mas ela sabe usar na situação.

E. Mas o que significa sabe?

A. $O$ que significa sim, o conjunto.

E. Mas não sabe analisar todas as partes?

A. Não, não sabe separar tipo assim né, é bem oral mesmo.

10'07' E. É mas é legal, isso aqui então vem dessa época da segunda metade do século XIX, então é dialeto é só da sua mãe da parte de Udine?

10'18' A. Acho que não, porque a gente tinha muito contato com esse nosso avô paterno, ele era muito carinhoso com a gente né o vô S. e ele falava também várias coisinhas assim com a gente, dos dois lados...

E. Que é também, que é do lado da Calábria...

A. no caso dele vem... mas eu não saberia te dizer o que que é o que

E. Que no caso mesmo é o italiano... isso não é de cá, nem de lá...

A. Éh, o que todo mundo fala...

10'43' E. Deixa eu ver se tem mais alguma coisa, acho que você já acabou dizendo assim sobre... e agora assim...depois, você acha que tem alguma coisa no Brasil que os brasileiros tem uma ideia do que que é...de como são os italianos? 
10'57' A. Eu acho que eles tem uma ideia equivocada estereotipada eu acho, então a coisa daquele italiano eh mamma mia que fala alto, não sabe gesticular muito, se você vai pra Itália e vai pra Roma você vai encontrar disso, mas vai encontrar sabe...vvocê tem o italiano que é mais neutralizado, você tem italiano...tem italiano de todos os tipos né, então você constrói essa imagem, acho que é muito equivocada tanto desse ponto de vista quando o ponto de vista da personalidade a o italiano é mais legal o italiano é mais aberto o italiano... acho que também é equivocado porque a gente encontra gente de todos os tipos

11'41" E. Ah sim...claro...mas é interessante pensar quais são os estereótipos que ficavam internalizados
A. Eles existem, é isso
E. Então você acha que falar alto...

11'50"' A. Falar alto, gesticular, simpático, bonachão, gosta de comer né, gosta de estar com a família né, essas coisas todas

12'02' E. E a coisa dos italianos serem autoritários, você já ouviu falar?

12'11" A. Não, não tenho isso construído pra mim, eu tenho construído pra mim assim a coisa de da família que era muito rígida mas na questão familiar, da educação, menina faz isso menino faz aquilo, foi assim até a minha criação, então jamais minha mãe pediu pro meu irmão lavar louça por exemplo, nunca, então esses papéis eram bem divididos. Agora uma coisa importante que tem no brasileiro que é equivocada é a questão da língua, então eles acham italiano é fácil pra caramba, eu vou pra itália eu falo...ih... tranquilo... isso pra mim é muito equivocado.

E. É, mas é só as pessoas começarem a estudar já percebem que não é

A. Mas ele acham...o brasileiro acha que a língua é igualzinho.

E. É quase...

A. Não é nada...não.

13'06' E.Tem mais alguma coisa que você lembre assim ou quer ainda...se acha que pode ser interessante pra você ou pra aquilo que você..

13'15' E. Não, eu acho que ai eu não sei se tem a ver com o trabalho de pesquisa de vocês, talvez tenha até mais a ver com o trabalho da $P$. que é a questão da casa, da residência, eu vi desde pequena as mudanças, a casa onde minha vó morava, questão do banheiro... na época da minha mãe era só pra fora depois o banheiro foi pra dentro, então tem essas coisas da casa que foram se modificando.

13'42' E. Virando mais próximas de como é aqui no Brasil? 
13'44"' A. Aqui no Brasil é, e a questão do banheiro por exemplo, me lembra o que minha mãe contava que a avó dela ali ia no no quintal com uma saia bem comprida longa que ela não usava as calçolas né a lingerie, não se usava naquela época, nem sei se tinha, então... e ela fazia xixi em pé, ia no quintal com a sua saia que era o que se fazia antigamente essa era bem velha né essa senhora avó da minha mãe, minha bisavó...é minha bisavó... então ela se lembra disso, no quintal tinha a tal da fossa ainda, eu cheguei a usar fossa, eu conheci fossa porque tinha fossa na casa da minha avó.

E. Entendi... muito bem...

A. A questão da comida tudo isso ficou bem marcado pra nós.

14'43"' E. Como você disse, se fazia essa comida mas não se dizia isso vem da ltália? 14'46" A. É mas tava tão claro pra mim, que não preciso dizer, eu já sabia, tanto da parte do meu pai quanto da parte da minha mãe.

E. Entendi, ótimo. Então muito obrigada.

A. De nada...

E. E vamos...

A. Foi um prazer (risos)

E. Legal.

15'02" A. Quando ele ouvia a língua, ele chorava, chorava... Só que ele não sabe mais falar, não sabia, já faleceu. Ele não sabia mais falar o italiano, nada, e o português dele continua com o sotaque totalmente italiano, isso eu achei muito interessante.

15'19"' E. Mas isso acontece muito viu, tem muita gente até que pessoas com um grau de instrução elevado, que depois de pouquíssimo tempo que estão aqui se não trabalham italiano se não tem a consciência da língua começam a misturar tudo, e depois de pouco tempo três, quatro anos, já não falam mais direito o italiano e não fala direito e talvez nunca falaram português, então fica sem uma língua. Ontem mesmo conheci um rapaz que acabou de entrar no ICB.

15'51"' A. Esqueci de um dado importante, que é a questão do dialeto, se bem que eu falei né, eu falei que se evitava o italiano, e era por essa questão do dialeto que vinha obviamente da Itália, culturalmente falando a questão dialetal.

16'10" E. O dialeto como algo que não se pode falar, porque essas pessoas não falavam o italiano né, era só o dialeto.

A. Exatamente... 
16'19' E. O que é interessante pensar o que a gente ainda tá vendo, é se...tem muita pessoas que dizem essa questão do não falar, mas de falar português, o que não sei se era porque é dialeto ou se era mesmo a coisa do italiano, mas isso seria mas na época da segunda guerra mundial, quando o italiano foi proibido junto com o alemão, quando teve todo esse momento em que não se podia falar italiano.

16'45" A. Não, eu acho que é anterior porque a minha mãe, ela nasceu em quarenta e um, no meio da guerra né

E. E ela já teve....

A. Meu pai nasceu em 34

E. mas eles já tiveram isso dos pais deles?

16'55" A. Sim, eles é que tiveram isso dos pais e não a gente, porque pra nós não chegou nada, só chegaram essas expressões que minha mãe ou meu pai...meu pai fala palavrão, todos os palavrões italiano, ele fala... (risos)

E. Ah...ótimo...lindo

17'15" A. Mas então assim, do ponto de vista linguístico eu vejo que os descendentes de italianos eles não fizeram força nenhuma pra consertar a língua

17'25" E. Então aí tem várias questões, tem a questão do dialeto, tem a questão de falar português pra se integrar na comunidade local, tem a questão da proibição do dialeto nos anos trinta, quarenta.

A. Trinta...quarenta...

17'38' E. Então tem uma série de fatores e aí justamente também isso que a gente né quer saber das pessoas que viveram pra entender qual desses fatores teve mais influência. Porque quando você diz que tudo... que dessa ideia de não falar italiano ou não falar dialeto é de, da época dos seus pais...

A. É porque minha mãe tem consciência disso, ela falava porque minha mãe falava que era dialeto.

E. Aí já tem um elemento que vai de uma certa criação... minha rinite é muito chata... A. Enfim né... Mas aqui é ruim para quem tem rinite...é horrível esse carpete aí...

18'15" E. Mais impactante, junto com o Estadão, o jornal...o segundo jornal mais difundido em São Paulo era o Fanfulla o tal de jornal italiano...

A. Do Bixiga esse? Ou não tem nada a ver?

E. O Fanfulla... não... O Fanfulla que foi publicado, que ainda é na verdade, mas assim... mudou completamente o seu papel... mas naquela época ele era lido 
evidentemente por muitas pessoas, ai quando se diz que ninguém fala o italiano e ninguém falava italiano
A. É esquisito...
E. tem aí uma...
A. Um problema
E. incoerência que inclusive esse tipo de entrevista com as pessoas, tende a procurar entender

18'54" A. É no caso da família, dos antecedentes do, da ascendência do meus pais, pensando nos bisavós eles não eram letrados né, eles eram analfabetos

E. Então porque tem esse dado né, então por isso que a gente fica imaginando [A. Que dia é hoje?] Hoje é dia 15... se as pessoas parece, têm relatos de as pessoas se encontrarem pra ler, se uma pessoa sabia ler, lia para os outros, ou então tem dados de reuniões de operários, reuniões sindicais, onde também se fazia essas atividades de leitura, mas de qualquer maneira era interessante porque se havia tantos jornais, havia um público...
A. Sim... e um público letrado, que sabia ler.
E. Um público letrado, que sabia ler...e no final com a Itália se unificou em mil oitocentos e sessenta e um, oitenta e cinco por cento dos italianos ou até mais eram analfabetos
A. Jura?
E. Aham
A. Eu não sabia disso...

19'54" E. Foi no comecinho do século XX que a Itália começou a um processo de alfabetização que não existe Itália...
A. Não existia a língua nacional né

20'04" E. Por isso que todo mundo que veio no final do século XIX falava dialeto, porque o italiano existia como um italiano literário, então só era conhecido das famílias, das pessoas mais cultas, mais letradas e não era a língua da fala cotidiana. Começou a se tornar língua mesmo das pessoas, primeiro porque foram feitos os projetos, os professores eram enviados de um lugar para o outro da Itália pra difundir italiano, se fazia serviço militar em uma outra cidade pra obrigar as pessoas a se entenderem por o cara da Calábria e um de Udine, nem sei como se falaram seus parente porque teoricamente um dialeto tão diferente não dá pra se entender

20'43"' A. Mas aí foi a minha mãe que encontrou com o meu pai 


\section{E. Então já falando português}

20'49" A. O meu avô paterno casou-se com a minha avó paterna que era também do sul...[E. E os outros também né?] e o meu avô materno casou-se com a minha avó materna que era do norte, não se misturava naquela época

E. A mistura aconteceu na geração seguinte

A. Aconteceu, exato, Já não tinha esse problema de língua, já se falava português

21'12' E. E aí, na verdade assim as pessoas então até comecinho do século XX não falavam italiano, não sabiam ler em muitos casos aí foi um processo muito rápido [A. foi mesmo] foi um projeto muito forte de italianizar, se dizia na época da unificação fizemos a Itália agora precisamos fazer os italianos porque não existia Itália, existia regiões distintas com dominações diferentes, línguas diferentes, dialetos tudo. Então as pessoas que vieram bem nessa época logo após a unificação, que foi uma época que a Itália teve muita miséria, muitos problemas financeiros que foi um dos motivos que fez muita gente vir pra cá, então pessoas que vieram nessa época muitas não sabiam falar italiano, não tinham ido pra escola, não sabiam nem ler muitas vezes. Quem veio já no começo do século XX, [A. um pouco mais tardiamente já veio né com essa] depois da primeira guerra, entre as guerras, depois da segunda aí já é outra...então por isso que é interessante perceber, quando que vieram pra saber qual era provavelmente a situação lá.

22'26" A. É porque a minha avó materna, por exemplo, nasceu mil oitocentos e oitenta e nove

E. É, é nessa época que muitas pessoas vieram

A. Meu avô, nasceu em mil novecentos, o paterno né. O materno veio de lá já nascido.

E. É, precisamos, eu acho que agora que estamos conseguindo... 


\section{APÊNDICE B - Transcrição da entrevista 02}

G: Não precisa falar "boa-tarde". Precisa? Não? Boa tarde? É boa noite já!

A: Boa noite. É um prazer estar aqui.

G: Obrigada.

A: Colaborando com a pesquisa de vocês. Espero poder conseguir responder e ajudar nessa pesquisa, já que é uma coisa que realmente tem a ver comigo, com a minha família, com a minha identidade. Com uma das minhas identidades. Que a outra é brasileira, não tem jeito. Mas me toca muito falar desse... Dessa temática aí do projeto de vocês.

G: Então, eu vou fazer a pergunta, acho que é melhor, né?

A: Faz a pergunta.

G: A., o que você sabe de como a sua família veio ao Brasil. Conta um pouco essa história... Em que período...

A: A minha família veio pro Brasil um pouco diferente dos outros imigrantes italianos porque nossa sede, nossa casa, era no Egito. E o Egito foi uma possessão, uma colônia italiana, no Século dezenove. A minha família, que é proveniente da Sicília...

01'22"' A: Minhas bisavós... Eles foram pra... Bisavós dos dois lados, foram pro Egito, bisavô do lado do meu pai foi pra Tunísia, que também era possessão italiana, então meu pai nasceu na Tunísia, minha mãe no Cairo, onde eu nasci também. Só que eles, o grupo, eles ficavam com o grupo dos italianos. Mantendo as tradições italianas, apesar de estar inserido numa outra realidade árabe, né? Então eles incorporaram algumas coisas dessa... Da sociedade egípcia. E quando houve a República, proclamação da República no Egito, com o Nasser. Obviamente todos os europeus, eles foram, de uma certa forma, meio que convidados a se retirar. Porque as taxações, as...

Porque eles tinham sido também explorados por vários... Pela França, pela Itália, Inglaterra...Então... Enfim. Aí, a ida pra Itália era problemática porque a Itália também tava em crise.

02'54" A: Nós viemos pro Brasil em mil novecentos e cinquenta e sete, e... Nós paramos no Porto de Santos, ficamos um tempo, um tempo na... ali na... ali onde fica o local dos imigrantes, inclusive tem um registro que eu já vi da nossa família. Havia uma irmã do meu pai que já morava em São Paulo. 
03'19'A: Então nós viemos para São Paulo, meus pais não são do campo. Eles tinham nível universitário, e meu pai era comerciante lá, minha mãe é economista. Então, nós não fomos pro campo, viemos pra São Paulo, mas meio que [com] uma mão não frente e outra atrás como todo imigrante.

03'39"' G: Que idade você tinha quando você...
A: Quando eu vim pro Brasil?
G: É, exato.
A: Dois anos e meio.
G: Ah, pequenininha.
A: Dois anos e meio e o meu irmão...
G: Você não se lembra de muita coisa.
A: Meu irmão tinha seis. Eu não lembro.
G: Claro.

A: Eu só me lembro da primeira casa onde a gente morou.

03'54'A: É a minha memória, da família que ficava muito unida. E nós fomos... Ficamos muito ligados ao Consulado Italiano. Eu estudei numa escola de padres que era ligada ao Consolato.

04'12’' A: [Inaudível]

04'19' A: Meu irmão lembra mais do Egito, porque ele chegou inclusive a ir à escola lá, eu não. Lá, eles eram...em casa se falava só italiano.

G: Sim.

A: Mesmo aqui, mesmo vindos ao Brasil. Não se falava português em casa.

G: E nem o dialeto.

04'39'A: Não, o italiano que nós falamos é o italiano acho que é o standard mesmo. G: Sim.

04'47' A: Se bem que eu já tive uma aluna, que inclusive foi aluna aqui do italiano, A. $P$., que foi minha aluna do inglês, e ela falou que o meu italiano é um italiano meio arcaico. Em alguns momentos.

G: Claro.

A: Provavelmente por conta dessa... É um italiano do século dezenove. Ela falou que às vezes até literário.

G: É, claro.

A: E é tanto que eu acabei fazendo um curso pra me atualizar que o italiano que eu falo é um italiano... Minha mãe diz que não é dialeto e não é mesmo. 
G: Sim. Sim.

A: É romano.

05'24'A: Minha mãe estudou em Firenze na época da guerra. Então, ela fala um italiano obviamente perfeito, então ela dizia... Agora ela tá com um problema de saúde, mas enfim... Ela foi tradutora de italiano até ter esse problema.

G: Sim.

A: Até recentemente, ela tem mais de oitenta anos.

G: Nossa.

05'52'A: Ela é tradutora juramentada de italiano.

G: Mas o que é interessante, provavelmente, nessa manutenção desse italiano, quer dizer, vocês...seus pais saíram da Itália.
A: Os avós saíram.
G: Os avós.

06'07' A: Então, o italiano...

G: Nasceram no Egito.

A: Meu pai nasceu na Tunísia...

G: Na Tunísia.

06'11' A: Minha mãe no Egito, depois a família do meu pai foi pro Egito.

G: Eles estudaram no Egito?

A: No Egito.

G: Tá. Então, mantiveram o italiano lá, já com nível universitário. Quer dizer, pessoas cultas, aprendem o italiano... Quer dizer, língua escrita. Que é...

\section{A: Sim.}

06'30''G: Claro que eles sabiam o dialeto, mas mantiveram um nível de língua alto e ele ficou cristalizado, provavelmente.
A: É. Eu nunca escutei eles [sic] falando dialeto. Eles falavam várias línguas.
G: Lógico.

A: Por que no Egito, naquela época, as crianças eram alfabetizadas em 4 línguas.

A: O árabe, o italiano, o francês, que minha mãe é fluentíssima também.

G: Sim.

A: Como realmente uma nativa, como se ela fosse francesa.

G: Nossa.

07'00' A: Porque houve uma grande influência francesa. E o inglês menos.

G: Tá. 
A: Então eles falavam essas línguas e depois com proximidade com outras comunidades, eles aprenderam grego, mas minha mãe sabia escrever inclusive o árabe. Aquele com pena. Escrita árabe que é difícil, né?

G: Que coisa.

A: Quer dizer, não é nosso alfabeto.

G: Lógico.

A: E redigia muito bem. Eles... Tanto ela quanto o meu pai, né? Só que quando vieram pro Brasil, não havia naquela época reconhecimentos de títulos, não tinha nada a ver ao que existe hoje.

G: Exato.

A: E eles tiveram que começar mesmo... Minha mãe começou como datilógrafa, no banco. Banco francês e brasileiro, onde um dos gerentes, diretores, conhecia ela do Egito. Era do Egito também. Então ela começou pra poder aprender o português. Porque eles já eram adultos. Então... Era uma outra língua.

08'11' A: Então, ela fazia cópias. Era como se eles fossem analfabetos. Então, eles não tinham uma colocação profissional. Meu pai era muito mais velho que a minha mãe. Ele pior ainda, né? Meu pai acabou trabalhando em restaurantes, empresas italianas. Ele era... Gerenciava o restaurante, porque lá ele era comerciante de laticínios. Então, ele tinha uma ligação com essa parte de comida.

G: Sim.

08'44" A: E a minha mãe trabalhava em escritório. Daí ela foi pro banco, passou a vida inteira no banco, se aposentou lá. Foi gerente, foi... Porque ela foi crescendo. São muito batalhadores, né? Todo imigrante...

G: Nossa.

A: Faz coisas que a gente fala... "Não, como conseguiu dar conta?"

G: Exatamente.

A: É impressionante o esforço. Fora de casa era o português, mas a regra dentro de casa era que não se falava uma palavra de português...

G: Muito legal.

09'22" A: Pra manter, porque eles sabiam que fora, inclusive nós, obviamente aprendemos com facilidade. Eu tive alguma dificuldade quando eu fui alfabetizada com o "R" que eu falava "barrata". Eu tive problema com o "R" do português, mas aí... E eu ainda escuto. Quando eu escuto a minha voz, eu escuto uma música do italiano 
no fundo, quando eu escuto gravações, então é meio cantado, quer dizer, é influência do italiano no...

G: Com certeza.

09'53" A: Agora eu falo menos, né? Mas com a minha mãe, em família, sempre se falou só italiano. E a questão de manutenção das tradições, a parte de alimentação foi mantida, com uma certa influência árabe, né?

G: Lógico.

A: Mas só o que cabia no... O que cabe no paladar do italiano, coisas que não cabem não iam.

G: Não vão.

A: Então, mantiveram essas tradições e... A tradição das festas. O meu aniversário nunca era comemorado no dia do aniversário, mas no dia da santa.

G: Sim, era o mais importante, o onomástico.

A: É, onomástico.

10'44" A: Mas aí houve aquele choque porque todo mundo comemorava no dia em que nasceu, e eu questionava, né? Então, eles tiveram que se adaptar a:: a:: algumas coisas do Brasil, né? O nosso arroz-feijão era macarrão todo dia, só mudava...

G: Que delícia.

C: [Inaudível]

A: Mudava o molho. Era pasta e fagioli, era com molho, era na manteiga, era alho e óleo,

sempre com uma carne, primo piatto, secondo piatto... Isso foi mantido, é.

G: Se manteve.

11'24" A: E algumas coisas que fazem parte das características do italiano. Algumas assim bem divertidas, outras menos, mas que fazem parte do modo como encaram 0 outro. A vontade de manter o grupo, então... Quando eu namorava, tinha que namorar com um italiano ou alguém descendente pra manter... Era muito engraçado.

G: Ficou forte isso.

A: Acabei casando com um descendente de italiano. Eu resis- foi acaso. Porque em São Paulo...

G: É maioria.

A: É maioria. Não era muito difícil acontecer isso. Mas a gente era... Eu não percebi uma resistência por ser São Paulo, aos italianos, na época que a gente chegou. Eu sei que o pós-guerra foi muito complicado pros italianos, principalmente porque a Itália 
perdeu a guerra. Mas quando nós chegamos isso já tava diminuindo. Havia tantos italianos em São Paulo.

G: Sim.

A: E eles se ajudavam. Então a comunidade se ajudou, nós tivemos escola, não pagávamos nada enquanto não podíamos pagar. E, então, a comunidade era muito unida.

12'47' G: É porque depois... Logo depois a Itália começou...

A: Exatamente, exatamente.

G: Foi no período em que os meus pais também vieram pra cá... Cinquenta e oito, minha mãe chegou em sessenta.

12'56"' A: Chegou em sessenta?

G: É, meu pai veio, eles estavam casados já, cinquenta e oito.

A: Por que a situação na Itália...

G: É.

A: Eles saíram do Egito, eles tinham a opção de ficar na Itália.

G: Mas ainda tinha uma crise.

13'07' A: Tinha uma crise muito grande. Então... O Brasil era muito falado como uma terra do futuro.

G: Exato.

A: E havia coisas, então eles... E a tempe- hã:: o clima era muito parecido, no caso do Egito. Lugares mais quentes.

G: Sim.

13'28''A: Então eles achavam que iam se adaptar. Mas a família toda se diluiu. Eu tenho uma tia, que já é falecida agora, mas que ficou na Itália, em Milão. Próximo a Milão. Tenho uma tia que foi pra Austrália. Irmãs da minha mãe, eu tô falando. Irmãs da minha mãe. Foi pra Austrália.

Minha avó com mais duas tias, porque eram cinco irmãs, vieram pro Brasil, mas minha avó não se adaptou e foi morar... Voltou pra Itália. Foi morar com a outra filha na Itália. E uma outra tia minha... Meu tio como era, também poliglota, todos eles eram poliglotas, ele foi convidado por uma companhia americana... Por uma companhia americana, mas pra ir pro Canadá e ela, como não se adaptava, não se adaptou ao Brasil, gostou do desafio de ir pro Canadá e viver uma vida... 
Então, tenho parentes no mundo todo, tem uma irmã do meu pai que também foi pra Austrália. A outra irmã tava aqui no Brasil. A outra irmã... Eram quatro, três vieram pro Brasil e uma foi pra Austrália. então, a família, ela...

14'52' G: Ela se espalhou...

A: Ela se espalhou porque imigração tem isso.

G: Uma família de aventureiros.

A: De aventureiros.

A: Eles tiveram que desbravar e todos...

G: Claro. Não têm medo.

15'04' A: E todos, todos, cada um no seu contexto, acho que eles se deram bem.

Todos conseguiram criar seus filhos, uns com mais possibilidades financeiras outros com menos, mas eu acho que todos, no momento, estão mais ou menos no mesmo patamar.

G: Que legal.

A: Todo mundo conseguiu estudar, todo mundo...

G: Sim.

A: Então, houve uma condição muito especial pra imigração e talvez...

15'36' A: Houve um sofrimento. Eu me lembro da dificuldade da minha mãe, porque morávamos num lugar pequeno, não se ganhava tanto dinheiro, porque não se dominava a língua. Até ela superar isso e trabalhar muito, muito, muito pra guardar um dinheiro pra poder ter mais qualidade de vida. Mas são os batalhadores. Realmente são os batalhadores e não dá... Eu não sei... Quando eu penso, eu lembro de como eles trabalhavam, eu fico pensando se a gente aguentaria o mesmo. Dizem que sim, mas é... Quando você tá numa condição de imigração, mas...

G: É, eu vejo pelos meus pais, também assim... É o que eu falo pra minha irmã. Eu tenho uma irmã mais nova. E eu falo: "Olha, quando você tá desesperada, e acha que sua vida tá um saco", desculpa aí. "Olha, fala com o papai e com a mamãe”.

A: Sim.

G: Não vejo esses dois...

A: Reclamando.

G: Reclamaram, reclamarem.

A: Se lamentarem.

G: Nada. Imagina. Meu pai, então...com oitenta e cinco anos e uma força... Minha mãe também. 
16'55'A: Eles são, eles são realmente...

G: Acho que é o perfil mesmo.

A: Tem um perfil. E um perfil, assim, de aceitar desafios, de não ter medo.

G: E ensinar isso aos filhos.

A: Exatamente. E, de todos nós... Eu sempre trabalhei. Trabalho desde os catorze anos, porque era isso. Não existe. Eu não sei ter ócio criativo. Isso é uma dificuldade, é um problema. É um problema.

G: Eu aprendi um pouquinho.

A: É um problema, porque...

17'26" A: Minha mãe, se tava assistindo televisão, tava fazendo tricô, tava fazendo crochê, tava costurando uma roupa, tava... Então ela dizia que quem fica lá parado... G: Você cresceu ouvindo isso.

A: É uma pessoa inútil. Então, eu não consigo. Se eu faço, eu me sinto culpada.

G: Que coisa, né?

A: Porque vem essa coisa do imigrante, e de não... Também acho que nunca vou me aposentar. Por conta disso, porque eu tô acostumada, sempre fiz mil coisas. Tô um pouco cansada, mas...

G: Lógico.

17'59" A: Minha mãe falava assim: "Mas como? Não se fazem mais mulheres como antigamente. Com a sua idade, eu tava ainda..." E é verdade, não dá pra dizer. Ela não... Nunca ouvi reclamação, nada. Acordava cedíssimo, fazia tudo que tinha que fazer e não tinha, assim, os confortos que eu tenho. E fazia tudo e não reclamava. Talvez porque a gente foi mal-acostumada.

G: Pode ser.

A: A ter certos confortos.

G: Exato.

A: Ou a gente tá em outro momento, ou talvez a gente não tenha sentido na pele o que eles sentiram. Porque quando você é criança, não tem... A tua referência é aquela da tua casa, então não tem essa. Talvez, hoje em dia, as crianças de grupos sociais menos privilegiados, eles tenham uma referência, eles queiram, elas cobrem mais os pais. Mas a gente não tinha. Então... Não tinha cobrança. E aquilo tava bom, se não tinha presente de Natal, não tem importância. É:: também não era uma coisa que era tradição.

19'15'A: A tradição era diferente, inclusive os presentes eram no dia dos Reis 
que trazem os presentes.

G: Dia seis.

A: Dia seis de janeiro. Dia vinte e quatro era dia...

G: La Befana.

A: La Befana. La Befana. Então, a gente fazia a Befana, mas depois a gente ficou maior e todo mundo ganhava presente.

G: Em casa também.

A: Só que ela não abriu mão do dia... Não é dia vinte e quatro, é dia vinte e cinco. Aí a gente ia dormir bem cedinho, pra acordar logo, pra poder... Mas tradicionalmente era na Befana.

19'48' G: Em casa era, a gente festeggiava. "Festeggiava"... Comemorava o dia vinte e cinco, a árvore era feita no dia vinte e quatro. Montada no dia vinte e quatro, presépio no dia vinte e quatro também. Aí tinha toda a messa in cena. $\mathrm{E}$ na Befana as meias cheias de doces e tal. Não presentes.

A: Não eram presentes, é isso mesmo. É isso mesmo.

G: Sorte que depois que eu li mais tarde que ela também podia... Se a criança não se comportava, ganhava um carvão. Eu vi em algum lugar isso.

20'21' A: Ai, ainda bem.

G: Ainda bem. Eu nunca ganhei carvãozinho.

A: Eu ganhava coisa simples. Tipo, aquelas coisas de...

G: Sim.

A: Eles não tinham dinheiro.

G: Lógico.

20'32' A: Mas eu amava, aquela coisa de... Que você molhava...

G: De pintar..

A: De pintar. Os desenhinhos

G: E aparecia a cor.

A: Aparecia a cor. Adorava aquilo.

G: Adorava

A: E eu ganhava aquilo de Natal. Imagina... Uma criança, hoje em dia, se ganhar aquilo de Natal...

G: Xinga o pai.

20'49' A: Eu achava ótimo.

G: É. 
A: Então eles mantiveram algumas coisas, por exemplo, no Ano Novo. Jogavam as coisas quebradas.

G: Que legal.

A: Jogavam num terreno baldio. Hoje em dia, isso seria politicamente incorreto, né?

G: Exato, a gente põe na reciclagem.

A: Põe na reciclagem, mas não havia reciclagem, então... A gente jogava, simbolicamente, um copo quebrado, pra que tudo se renovasse no ano seguinte.

21'21' G: Que legal.

A: Simbólico. Aí o bolo tinha uma moeda, a gente juntava. A gente giocava a tombola. 21'27"' G: Olha lá "giocava"!

A: A tombola.

G: Você tá se soltando.

A: Tombola.

G: Sim, la tombola.

A: No dia de Natal era a tombola, eu amava...

G: Eu também.

A: Porque eu sempre ganhava.

21'36'" G: Eu não.

A: Era um dinheirinho que eu ganhava.

G: A gente jogava muito a tombola.

A: Muito. Só no Natal.

G: Toda entrevista eu dou meu depoimento aqui. Depois o pessoal vai fazer um... Porque eu também...Eu tô entrevistando.

A: Mas é bom porque você me ajuda a lembrar. Então, a tombola era uma coisa assim de...

G: Verdade.

21'55' A: Ah, eu adorava o Natal, sempre. Gostava, apesar de não ter presentes caros, não ter... Montar árvore, essas brincadeiras. A gente sabia que era um almoço especial. Agora, a coisa mais importante, a comida nunca faltou na mesa. E sempre...aquelas comidas bem... Os grãos, que não era muito comum aqui. Tirando o feijão, as pessoas não tavam acostumadas. Hoje em dia que voltou, né? Você ter a ervilha, a sopa de ervilha... O grão-de-bico.

G: O grão-de-bico, i ceci.

A: I ceci. Nossa, eu não gostava, hoje em dia eu adoro. 
G: Exato, a gente aprende.

22'35" A: Porque a gente comia, como é que falava? Nossa, faz tempo que...

G: Vai!

A: A sopa...

G: I/ minestrone.

A: Il minestrone. I ceci. Tudo em forma de sopa, ensopado, com músculo...

G: Sim.

A: Com coisa que desse muita proteína. E a massa, né? que meu pai comprava de caixa. O pessoal falava... Pensava que ele tinha restaurante, mas ele comprava aquelas caixas com todos os tipos de macarrão. Principalmente spaghetti, que era o preferido, e minha mãe fazia com vários tipos de molho... À bolonhesa, pesto, enfim, tudo.

G: Tudo. E A., você tem quantos irmãos?

A: Eu tenho um irmão.

23'28' G: Só um irmão.

A: Só um irmão.

G: E vocês conversam em italiano?

A: sim, mas hoje em dia não. Hoje em dia conversamos em português.

G: Que coisa.

A: É muito esquisito, muito esquisito. Porque...

G: É raro acontecer isso.

23'41' A: Porque talvez por um distanciamento da vida... Então, aquela... O italiano é intimidade.

G: Então, vocês...

A: A intimidade já não é tão forte.

G: Tá.

A: Então, que cada um seguiu o seu caminho. E minha mãe une. Quando estamos com ela só falamos em italiano.

G: Que lindo.

24'07' A: Mas quando eu falo com ele, a gente não fala em italiano, às vezes uma palavra ou outra, mas eu acredito... Pelo o que eu... Também estudo questões identitárias... Eu vejo que é por que não há uma... É justamente essa coisa do vínculo, do pertencimento, da intimidade que...

G: Sim. Sim. Que se rompeu. 
A: Que se rompeu porque cada um seguiu um caminho, moramos distantes. Então, há um distanciamento daquele período.

G: E você tem quantos filhos?

A: Eu tenho três filhos. Eu não falo, eles riam muito quando eram pequenos, mas eles entendem, todos entendem o italiano. $E$ [eles] se viram, mas não falam.

G: Você não manteve...

A: Eu não consegui, porque meu marido não falava italiano. Meu marido é descendente.

G: E não veio, quando você ficou grávida ou teve o bebê, o italiano pra conversar? Que coisa
A: Não veio.
G: Porque pra mim veio.

A: Não veio.

25'07' G: A primeira, quando eu vi o L., eu comecei a falar em italiano. E o meu exmarido, o pai, também só entendia o italiano, e eles cresceram bilíngues. Macarrão, né? Macarrônico, mas eles falam italiano.

A: Mas é porque meu marido não falava, ele aprendeu, de tanto... De época de namoro, chegar em casa, bater na porta e achar que mós estávamos nos estapeando. G: Sim, sim.

A: Aí abria a porta e a gente tava dando risada conversando normalmente. Mas é que italiano fala mais alto.

G: Que engraçado, e você então não... É porque isso é individual.

A: Eu não consegui, a minha filha dava risada quando eu falava italiano.

G: Lógico.

25'45' A: E aí não havia mais ninguém pra... Minha mãe trabalhava, tava distante então não tinha um vínculo. Mas quando ela vinha em casa, eu nunca deixei de falar italiano com ela e eles tinham que se virar pra entender.

G: Lógico. Mas é muito interessante.

A: Aí aprenderam. Eles entendem tudo, falam muito pouco, mas têm muita vontade de estudar italiano. Meu filho, agora, tá morando no Canadá.

G: Que legal.

26'09' A: Meus filhos também são viajantes. Eu acho que tá no sangue.

G: Tá no sangue mesmo.

A: A imigração tá no sangue. Ele já imigrou, o outro vai imigrar pros Estados Unidos. 


\section{G: Que legal.}

26'22' A: E o que foi pro Canadá teve que estudar italiano porque ele fez gastronomia.

E ele fez cozinha italiana. E uma das exigências era que ele falasse italiano.

G: Lógico.

A: Então, ele estuda italiano. Ele fala comigo, mas ele entende tudo, mas eu não consegui ter o italiano como língua de contato com meus filhos.

G: Que coisa.

A: É uma pena.

G: Eu... Mas veio, brotou, com os bichos.

A: O meu não era natural, era artificial, soava artificial.

26'52' G: Eu não, tanto é que a gente fala um dialeto, uma coisa totalmente diferente. O meu italiano não é o italiano que eu falo aqui mais polido. Nossa, em casa é muito engraçado. Olha lá, toda vez eu falo isso, eu falei: "Já tem coisa repetida, hein?". Não é, é que não dá pra não falar disso.

A: É logico.

G: Eu não sei a E. se consegue ficar quieta...

27'19' C: Não, é inevitável argumentar...

A: É porque a gente tá batendo papo.

G: Mas é muito legal. Daqui a pouco...

C: Até mesmo pra comparar... As famílias.

27'30' A: Agora, com a minha mãe fala... Minha mãe infelizmente teve um AVC que afetou justamente a linguagem.

G: Que pena.

A: Então, ela fala... Mantém algumas palavras do italiano, mas eu só falo com ela em italiano.

G: Sim.

A: Mesmo agora que ela não entende.

G: Sim.

A: $E$ que ela fala uma língua que não é nenhuma.

G: Sim.

27'49"' A: O italiano ela não perdeu e algumas palavras do português ela não perdeu, mas as outras línguas ela não entende mais nenhuma.

G: Que pena.

A: É uma pena. 
G: Uma judiação

A: É uma [judiação]... Mas eu quando converso com ela, doente mesmo, assim que ela tá afetada. Afetou a memória. Mas eu falo em italiano, ela reconhece, ela sorri.

28'14" G: Porque é do afeto mesmo.

A: É do afeto.

G: É língua do afeto.

A: Língua do afeto.

G: Não adianta.

A: E ela reconhece nosso vínculo. Eu tenho falado menos, porque justamente, eu falava com ela todos os dias no telefone. Quando ela não ia na minha casa. Então... E agora eu falo, não falo coisas muito elaboradas porque ela não entende.

G: Lógico.

A: Então, eu uso as coisas... Hai fame? Sei stanca?

G: Que bonitinho.

28'45" A: Coisas assim. Então... Coisas muito simples pra, assim... Do estado físico dela... Hai sonno? Coisas assim.

G: Mas você tem um italiano muito lindo. Você tem uma pronúncia muito...

A: Cê acha?

29’02"'G: Só dessas "Hai sonno?". Doppia enne. Lógico, siciliana também tem que... Não é só doppia, né? Eu brinco que eu falo que sicilianos não põem as duplas. Eles põem quatro, não dois "enes", quatro "enes". O meu pai é siciliano, então, quando eu converso com os meus tios da Sicília eu morro de rir. Eu falo: "Gente eu me sinto numa montanha-russa".

A: Quando eu fui pra Sicília...

G: É muito engraçado.

A: Eu passei por toda a cidade. Até onde minha avó... Os antepassados dos meus avós, do meu pai... Nas cidades que eles... É:: quando a gente pedia informação, o pessoal falava... Lógico, falava assim: "A. vai lá"...

29'52'A: Á..

G: Á..

A: Á..

29'55"'A: E eu escutava e falava assim meu deus do céu, eu não falo italiano, eu não falo italiano. Eu não conseguia entender e eu tinha que falar porque... G: Eles mesmos falando o italiano regionalizado é muito forte. É muito forte. 
G: É muito forte, eu entendo por que eu já tenho uma familiaridade com esses tios, mas eu tenho parentes de norte a sul, né? Minha mãe é trentina.

A: Ah, então, são os vários dialetos...
G: É muito divertido, muito divertido.

A: Agora, um que não dá pra entender... Que a primeira vez que eu fui, eu falei: "Meu Deus do céu, é outra língua..." É o vêneto, né?

30'33" G: Já pra mim é muito tranquilo, porque minha mãe é trentina. É muito próximo, né? Agora, é lógico, um vêneto falando o vêneto pesado, assim... Eu passava nos bares às vezes, eu ouvia os rapazes... "Os rapazes", o pessoal jovem conversando e é muito difícil. Porque era o dialeto veneziano...

A: Exatamente.

G: Aí eu ficava perdida.

A: O dialeto veneziano é muito difícil. Eu ficava só... Porque... Curiosa, daí eu escuto a música da língua. Porque a gente trabalha com língua, você observa coisas... Você tem interesse.

G: Isso.

A: Então, eu ficava escutando e falava: "Nossa, essa música é mais moderna. Ai, a

A. tinha razão, minha música é mais antiga..."

G: Mais arcaica.

31'24" A: É mais arcaica, mais assim... Não é aquele rápido. Então, eu perdi.. A fluência não é a mesma e não tem essa cadência. Porque a língua é dinâmica. A gente sabe, né?

G: Lógico.

A: Tanto o italiano como o português. Como o inglês.

G: Lógico. Todas as influências ao longo dos anos...

A: As influências, né? Então, tem tanta coisa... eu fui fazer o curso de italiano com a A.. Eu fiz aqui o curso de extensão. E eu me divertia porque eu queria ter contato com o italiano moderno. Saber como se falava... Agora, eu fiquei meio frustrada, né? Porque algumas coisas, né?

G: Como por exemplo?

A: Computador.

G: Ah, computer.

A: É, computer. 
32'07" A: E eu falei assim: "Escuta, não tem uma palavra em italiano?" Porque no francês eu sei que tem.

G: Sim.

A: O italiano não criou uma palavra? Weekend?

G: Weekend. Eu falo... E o pior é o inglês deles, né? É muito engraçado.

A: É, é engraçado. Eu reconheço um italiano falando inglês.

G: Ai gente, é muito engraçado.

32'26" A: É bem... E, provavelmente, eu também falo, se bem que eles dizem que eu tenho sotaque de sul-americana.

G: Tá.

A: Quando eu falo italiano...

G: Eles percebem.

A: A minha maior frustração foi em Roma.

G: Eles percebem.

A: Eu fui comprar alguma coisa. A primeira vez pisando na Itália, faltava só beijar o chão que nem o Papa. "Ah, minha terra, não sei o quê!"

Chego lá, o cara fala assim: "Você fala bem italiano, mas [de] que parte da América do Sul você é?

G: Exato.

A: Eu falei: "Putz, eu não sou italiana".

G: Eu, uma vez em Roma, eu fui comprar...

A: Eu nem falava, eu falava: "Não, aprendi muito bem".

33'05" G: O começo ele falou assim: "Você vai pro Brasil? Vai visitar alguém lá?" $E$ eu falei: "Não, eu sou brasileira eu tô voltando". Daí ele falou assim: "Nossa, você fala muito bem italiano. Quase não notei. Eu achei que você fosse do norte da Itália." Eu falei: "Realmente, eu tenho... A minha mãe é trentina. Ele falou: "É, realmente... Não, mas agora você conversando comigo eu noto que tem alguma coisinha no fundo que denuncia você. Você não é italiana".

33'38' G: Aí fiquei chateada.

C: Não precisava...

A: Eu fiquei tão murcha. Eu falava assim, falava pro meu marido: "Olha, eu tô sentido no sangue a Itália, olha a Itália que meus pais sempre reportavam...". Então, ficou nessa memória dessa identidade.

G: Nossa, mas muito legal. 
34'01"' G: Eu não sei A. M. se você quer falar mais alguma coisa... Você ficaria... Acho melhor interromper um pouquinho. 


\section{APÊNDICE C - Transcrição da entrevista 03}

01" S: É\# então D. \# é::: o que você sabe de como a sua família veio para o Brasil? 06" D: É::: na verdade eu fiz uma pesquisa muito grande depois de eu te uns quinze anos de idade porque minha família ninguém sabia de nada porque eles tinham vindo pro Brasil né minha mãe sempre me dizia que o meu bisavô meus dois bisavôs paternos são \# maternos desculpa são italianos mas cada um de um lugar diferente eles se conheceram no Brasil e se casaram aqui e minha mãe sempre me dizia que:.: eles tinham vin- meu bisavô tinha vindo fugido da guerra \# e aí um dia conversando com a minha mãe devia tá no \# com quinze anos no primeiro colegial alguma coisa assim eu peguei o meu livro de história e falei não tinha guerra nessa época não é possível mil novecentos e onze não tinha primeira guerra mundial não tinha começado não sei o quê aí eu comecei a pesquisar e a tentar entender o que tinha acontecido até que uma prima me contou\# o que tinha acontecido o meu avô tava vivo na época e num falava nada e \# conversando com essa prima mais velha ela falou olha hã\# uma tia irmã do meu avô uma das filhas do meu bisavô me confessou uma noite passou um segredo que não sei o quê ele veio fugido pro Brasil porque \# ele tinha matado uma pessoa na Itália \# hã::: acho que aos treze anos mais ou menos eu descobri algumas cartas da::: \# a correspondência entre ele e os irmãos que ficava num \# porão que tinha na casa da minha avó que é a casa onde ele \# que ele construiu aqui em São Paulo e essas cartas elas eram muito confusas porque elas não eram escritas em italiano algumas sim em italiano algumas escritas em dialeto e::: a maior parte escrita por analfabetos né \#

01'43" D: Então \# era muito difícil entender o que eles tavam escrevendo porque a::: a gramática deles não existia porque eles escreviam como eles ouviam como eles entendiam a:::s as palavras e::: eu comecei a perceber que o meu bisavô que eu sabia que chamava F. não chamava $F$. \# tinha algumas rasuras nas cartas e por baixo a gente vê que tinha um G. falei mãe mas alguma coisa de errado tem não é possível porque imagina D. ele chama F. tem \# a gente tem um primo que é chama $F$. por causa dele e aí é::: essa minha prima me contou que na verdade ele chamava G. é::: e que ele veio pro Brasil com documentos porque já tinha toda a documentação dele e que ele mudou de nome pra não ser encontrado nã nã nã \# e aí aos poucos eu comecei a entender hã::: o porque dele ter vindo pro Brasil qual foi a- o que tinha 
acontecido na Itália que fez com que ele viesse pro Brasil e perdesse completamente o contato com a::: com a família na Itália

02'42' S: E aí eles \# eles vieram diretamente para São Paulo ou eles hum \# ficaram em outras cidades antes?

02'48'” D: Então como ele teve que fugir das cidades \#

02'50”' G: Por que foi só ele né?

02'51' D: Foi vei- veio sozinho

02'52" G: Isso veio sozinho né.

02'54"' D: É diferente da::: não foi uma família que:::

02'56"' G: Exato

02'57' D: que migrou né ele veio sozinho tem na verdade ele começou um percurso de fuga dentro da::: da cidadezinha dele que era::: em província de Foggia na Puglia ajudado por um padre de lá:: chama Roseto Valfortore a cidade de lá ele foi \# pras cidades maiores perto que são Lucera e Biccari de lá ele foi pra Napoli e pegou um navio que devia levá-lo pra Buenos Aires pra Argentina e ninguém sabe porquê ele parou em Santos e aí ele ficou trabalhando como estivador um período no porto de Santos até que ele chegou em São Paulo é::: na rua Carneiro Leão que eu não me lembro muito bem se é Brás ali eu acho que é o bra- no bairro do Brás.

03'42' G: Que idade ele tinha?

03'45' D: Ele tinha ele é de::: acredito que dezoito anos vinte \# entre dezoito e vinte anos.

03'54'” G: Muito jovem \#

03'55' D: Muito jovem

03'56'" G: Muito jovem

03'57' D: Porque depois hã::: eu consegui recontatar a família porque a gente tinha essas cartas até a década de sessenta \# ninguém mais na minha casa falava italiano um dos meus tios avós falavam e o resto \# minha vó a mulher do meu avô que não é parente dele ela sabia algumas palavras em italiano algumas palavras em dialeto ela ah porque eu lembro do seu F. porque ele viveu no Brasil como F. hã::: meu avô conforme foi envelhecendo foi voltando a falar o que ele ouvia em casa porque a mãe \# o pai era de um lugar a mãe é era de Capaccio da província de Salerno então cada um falava o::: o meu bisavô falava que aonde ela morava era muito atrasado que eles não sabiam montar num burro eles montavam ao contrário \# imagina um falando do outro como se eles tivessem vindo de uma super metrópole né e::: então nunca teve 
essa a tradição do italiano se perdeu completamente na década de 60 e depois eu até entendi o porquê ele queria se integrar na::: \# na sociedade brasileira da sociedade de São Paulo da época e falar italiano pra ele era::: \# mostrar a identidade dele né mostrar que ele não era brasileiro então me falaram me contaram nunca conheci hã::: que ele falava muito bem o português praticamente sem sotaque só quando ele ficava muito nervoso que vinha o::: \# a italianeidade saía e \#

05'21" G: Ele apagou

05’22' D: Ele apagou completamente e na época da::: da segunda guerra mundial que é a \# recordação mais recente que a gente tem né hã::: que a minha mãe lembrava meus tios lembravam ele não ligava o rádio ele não queria ter contato nenhum porque por muito anos disseram que a polícia estava atrás dele então ele não queria ter contato com a::: com a Itália ele não queria saber de nada ele tinha medo de que chegasse a polícia pra prendê-lo aqui no Brasil \# e::: então foi isso o percurso dele até chegar na::: em São Paulo.

05'55' G: Super interessante né? Doloroso inclusive né

05'58' D: Acho que bastante a primeira carta que a::: que eu consegui hã::: \# que eu recuperei não me lembro exatamente a data mas é de quarenta e cinco mais ou menos \# quarenta e se \# acho que no princípio da guerra já \# deve ser quarenta e seis ou quarenta e sete \# é uma lista de mortes então é o i- é o irmão mais velho contando pra ele minha mãe morreu no ano tal nosso irmão tal morreu no ano tal nosso pai morreu no ano tal então depois de trinta anos ele chegou no Brasil em mil novecentos e onze mais de trinta anos ele teve o primeiro contato com a::: com a família e foi assim sabendo todo mu- todos aqueles que tinham morrido porque \# obviamente todos tinham morrido esse irmão sempre assustava muito ele nas cartas dizendo toma cuidado porque eu soube que a polícia está atrás de você \# imagina se a polícia viria até o Brasil atrás dele né

06'53' G: Exato \# na época ainda né

06'55' D: É, e::: então ele nunca mais voltou pra Itália nunca mais teve contato com \# teve que o contato era assim através das cartas

07'03'' G: Sim

07'04" D: Mas aí ele morreu na::: nos anos sessenta e acabou o contato

07'08'” G: E:::: e::: essas cartas você é:::: você tem e:::

07'14'” D: Tenho \# estão aqui

07'15' G: Você trabalha com elas? 
07'17' D: (risos)

07'17' G: Trabalhou com elas?

07'18' D: Eu trabalhei bastante essas cartas porque foi uma espécie de redescoberta de::: da minha origem

07'24”' G: Lógico

07'25' D: Eu queria entender porque minha família tava aqui né porque eu me encontrava em São Paulo se eles tinham \# se a gente tinha essa raiz italiana se a gente sempre tinha dentro da minha família uma italianeidade muito forte sei que tava vinculada a algum lugar vinculada a um país que ninguém entendia o porquê exatamente e foi por isso que eu comecei a estudar italiano pra tentar entender essas cartas \# e eu só consegui realmente entender depois que eu passei um tempo com a minha família lá porque eu acabei reencontrando os hã sobrinhos do meu bisavô que o conheceram que sabiam de toda a história e que me contaram toda a história e aí eu comecei a entender um pou- entender \# consegui me orientar dentro do::: do dialeto deles do jeito que eles falavam e aí lendo as cartas as vezes até em voz alta pra poder entender e conseguir reconstruir a história dele né como ele porque ele tinha saído o que tinha acontecido e da primeira da segunda vez que eu estive um tempo maior com eles eles me fizeram um percurso enorme me mostrando um percurso parece que a gente tava em Paris né (risos) [08'33"'G: não mas é] mostrando aqui era onde mora hã::: onde a namorada dele morava você vai dormir na casa onde ele dormia aqui morava a namorada dele aqui aconteceu o crime aqui foi aconteceu não sei o quê aqui era onde lavavam as roupas foi muito engraçado isso foi em dois mil mais ou menos as pessoas me encontravam na rua e choravam \# me abraçavam e choravam ela é neta do G. gente mas o G. saiu daqui há cem anos atrás (risos).

09'05' G: Mas você vê o carinho né?

09'08' D: é

09'09' G: quer dizer até a grande proteção que ele teve pra sair e o carinho de receber 09'15' D: sim

09'16' G: é hã

09'18' D: a bisneta

09'19' G: a bisneta né até e fazer o percurso olha só que é lindo isso

09'23" D: mostrar exatamente onde era a masseria onde é que como eles saíam o caminho que eles faziam pra ir às árvores que nem é mais da família hã::: e sempre um carinho muito grande na hora de falar dele explicar o que tinha acontecido não sei 
se é verdade ou não mas a eles me diziam que meu bisavô era o bonzinho da história e que a outra família que era uma família de desgraçados tinha sido completamente banida da cidade \# entã:::o eles sempre se referiam a essa família que eu não me lembro o nome aqueles desgraçados não estão mais aqui.

10'01' G: Tá deve ter acontecido mesmo porque pra família ter saído da cidade né quer dizer ele matou alguém dessa família

10'09' D: Ele matou uma pessoa dessa família que agora na verdade eu não me lembro exatamente dos nomes [10'15”' G: Ló::gico] uma das das irmãs era uma família bem grande namorava com essa pessoa e ele saiu contado pra cidade inteira pra desafiar meu bisavô hã:: contando que tinha tido relações sexuais com a irmã dele em mil novecentos e onze.

10'30" G: Aham então você imagina então foi um crime de honra mesmo.

10'33' D: É e::: todos os irmãos ele tinha um irmão mais novo que tinha oze anos naquela época e todos eram mais velhos e casados se eu não me engano ele tinha dezoito anos \# então a família escolheu a família se reuniu e decidiu que ele seria o::: \# assassino né que ele iria fazer o trabalho porque ele não tinha família né e o outro era muito pequeno então é muito interessante essas cartas que eu tenho aqui que é do irmão mais novo D. pro meu bisavô é o amor e admiração que ele tinha pelo meu bisavô eu não me lembro do dia em que você foi embora

11'13" G: Nossa gente é muito lindo

11'15' D: É muito interessante isso né e conta bem isso fica muito claro esse essa admiração \# eles acabara:::m idealizando o meu bisavô como a pessoa que fez o que devia ser feito né resolveu o problema da família até meu tio hã::: \# que tem mais de noventa anos hoje ele fala as mulheres daquela família não eram muito boa coisa (risos)

11'42' G: Gente olha só é naquela época né agora se a gente passa pra hoje é uma coisa absurda né.

11'50" D: Exatamente e::: \# e foi isso então hã::: ficou sempre essa grande lacuna na na minha família né \# do onde tá a família na Itália? Por que estamos aqui? Por que somos os únicos a estar aqui? É todo o resto da família continua não continua lá mentira foram pro eles imigraram pro Canadá porque esse essa cidadezinha que é Roseto noventa por cento da população mora no Canadá.

12'19' G: Puxa 
12'20" D: É ou na Pensilvânia e a atriz principal da história também teve que sair da cidade e ela foi pra Pensilvânia.

12'30"' G: Entendi

12'31' D: Então no Brasil mesmo só::: \# a única família P. é a a minha família porque todos os outros estão ou no Canadá ou nos Estados Unidos.

12'43"' G: Que veio hã::: veio

12'44' D: Só ele fez o percurso

12'45' G: F.

12'46' D: F. fez um percurso

12'46', G: G. F.

12'47' D: Fez um percurso completamente diferente dos outros ele não podia ir pro Canadá onde tava toda a cidade.

12'54"' G: Exato exato

12'55' D: Então ele veio pro Brasil

12'56' S: E ele contava alguma história da Itália na:.:

13'00' D: Pelo que eu sei ele falava muito pouco da::: da ltália e tinha muito medo de::: de tocar nesse assunto de despertar esse interesse dos filhos tanto que só depois eu fiquei sabendo que o meu avô sabia e meu avô veio me contar as coisas um pouco envergonhado \# toda vez que eles contavam era assim é mas ele era uma boa pessoa (risos) \# e essa imagem de uma boa pessoa sempre hã a gente sempre teve dele né todo mundo falava que ele era muito bom que era muito calmo que ele era muito tranquilo hã::: acho que foi também criando isso pra justificar o que tinha acontecido 13'36" G: Claro claro claro

13'38' D: Acontecido antes as histórias ele se assustou muito quando chegou no Brasil porque::: era realidade muito diferente da dele né \# ele vinha dessa cidade que na época tinha nove mil habitantes que hoje não tem mais do que novecentos habitantes é no alto da montanha

13'55' G: Gente novecentos habitantes

13'56' D: Novecentos habitantes na montanha onde na Puglia que né na Puglia que neva na Puglia que faz frio num lugar que tá muito próximo da Campagna então eles tem um dialeto diferente hã::: não é nem pugliese e nem o dialeto napolitano hã::: eles ficam isolados pela neve se neva não tem como sair os idosos tem que sair de helicóptero imagina que na época isso nada acontecia

14'20”' G: Lógico 
14'21" D: Ele chegou em São Paulo a primeira coisa que ele viu no porto foram os negros não existiam negros lá \# isso assustava muito ele então ele começou a inventar histórias sobre a::: \# origem dos negros e aí outra coisa que ele fazia também era acolher os italianos que precisavam hã::: de casa ele acolhia as pessoas na- [14'44" G: que interessante] quando ele sabia que alguém precisava de alguma coisa e tava vindo da Itália ele acabava recebendo

14'49"' G: Interessante né quer dizer uma pessoa que:::

14'51"' D: Não da família dele [14'53"' G: não mas exato] da família da- os amigos os conhecidos da família da minha bisavó

14'58' G: mas não importa né

14'59"' D: mas ele sempre recebia

15'00"' G: é como uma::.: uma missão mesmo né \#

15'03" D: Tanto que o túmulo da família onde ele tá enterrado tem uma série de pessoas uma série de italianos que eram as pessoas que moravam ali construiu três casa no terreno ele alugava essas casas as pessoas morriam não tinham onde ser enterradas eram enterradas no túmulo da famíla

15'19" G: Da família (risos) Muito legal isso \#

15'24" S: E que língua se falava na sua casa é::: alguém ainda fala italiano?

15'30" D: Eu sou a única que fala de verdade que fala italiano na casa sempre foi um \# sempre se falou português ele falava português hã::: muitas palavras do- do dialeto dele né da cidadezinha dele mas ninguém hã::: o italiano não foi \# não foi repassado e eu acho que é uma coisa até bastante comum na época das pessoas não não repassar como a gente pode dizer \# tramandare

16'01"' G: Tramandare é entã:::o não repa:::- (risos)

16'04"' D: Não repassar

16'05" G: É tramandare mesmo porque é difícil né

16'09" D: é::: eu acho que são várias as causas aí um dia eu já começo a pensar um pouco mais longe assim não só o problema dele pra ele se integrar ao Brasil mas dele não ter amigos da mesma região aqui então ele não tinha como falar a língua dele porque o italiano realmente não é que ele falava italiano \#

16'25" G: Exato ainda mais né nesse período

16'27' D: Mil novecentos e vinte o italiano era muito novo

16'30"' G: É::: 
16'31' D: Então acho que o português acabou virando uma língua franca hã::: que era como ele conseguia se comunicar hã::: voltando fazendo essa viagem pro::: hã::: pro passado né eu comecei a perceber muita influência na::: no estilo de vida da minha família hã::: uma influência muito forte italiana muito forte daquela vida daquele lugar daquela região mas que pra gente sempre foi uma coisa natural a gente não conseguia entender isso como uma como uma influência hã::: então as comidas hã::: o jeito de::: de se comportar a construção das casas eu lembro que hã::: os meus familiares quando viram as casas a foto da casa dele falou assim mas isso é aqui hã::: não no Brasil mas ele construiu igual as casas são iguais então ele construiu tudo com a memória que ele tinha

17'22' G: Exato ele manteve o que não digamos o que não incomodava o que não podia digamos identificar como a língua coisas mais vivas né que se movimentam mas ele falou não a minha identidade tá aqui né

17'43" D: Aham exatamente exatamente \#

17'44"' G: Na comi- e também a comida né

17'46" D: A comida também mas aí eu eu acho também que devia ter um pouco de influência da minha bisavó \#

17'49"' G: Lógico da bisavó

17'50" D: Que era quem cozinhava \# e que acabaram repassando pra essa tia hã::: o meu bisavô foi uma das uma- ele teve um câncer que depois eu descobri fui tudo eu que fiz (risos) a família inteira há gerações e gerações mais ou menos como estava falando todos tem câncer todos é uma coisa impressionante desde o avô do meu bisavô até a minha mãe todos tiveram tiveram câncer ele fez um dos primeiros transplantes de::: \# de bexiga e não sobreviveu ao transplante acho que ele morrem em sessenta e quatro mais ou menos acho que por aí e logo depois a minha bisavó teve um derrame mentira antes dele \# dele falecer ela teve um derrame e praticamente não enxergava e nem andava hã::: então a filha mais velha assumiu toda a família a filha mais velha deveria casar tinha o enxoval pronto \# tanto que eu encontrei as cartas junto com o enxoval dela quando eu tinha quinze anos estavam jogando fora (risos)

18'57' G: Nossa gente você então pelo amor de Deus né \#

19'01" D: É:.: \# imagina quantos anos já tinha passado né ela morreu em oitenta e quatro eu nasci em setenta e quatro \#

19'07' G: uhum 
19'08' D: já tinha passado muitos anos desse casamento que não aconteceu ela virou a mãe a matriarca\#

19'13"' G: Gente

19'14"' D: Ela virou a mãe da própria mãe então ela que repassou toda a::: \# a cultura culinária foi a minha tia M. que::: que repassou \# uma outra coisa interessante também são os nomes né hã::: a gente com- pra mim é uma coisa \# casual eu tenho um tio que chama Leonardo uma que chama M. hã::: um primo que chama F. coitado que \# G. não tem nenhum.

19'44"' G: (risos) G. não se usa (risos)

19'46" D: E minha mãe depois contou pro F. eu falei que maior maldade que ela poderia ter feito em vida era ter contado

19'52"' G: Imagina

19'53"' D: Porque é um orgulho pra ele ter o nome do avô ela falou assim mas ele não chamava F. ele chamava G.

19'58'" G: Nossa que dó \#

20'01"' D: hã::: e esses nomes L. M. são os nomes dos irmãos do::: do meu bisavô na Itália e tinha essa::: essa coisa de repetir os- os nomes né \# então até hoje tem uma uma das filhas \# de uma prima de uma prima bastante longe que mora no Canadá que deve ter uns cinquenta sessenta anos ela chama $M$. porque essa minha tia chamava M. porque a avó chamava M. e eles foram repassando os nomes então a gente volta na árvore genealógica e os nomes são \# são todos iguais

20'36"' G: Se repete

20'37' D: Se repetem (risos).

20'39" S: E como você acha que foi ser italiano em São Paulo?

20'43"' D: Pra ele

20'44" S: isso

20'45" D: Hum \# que eu saiba ele sempre é:.: o núcleo de amigo de amizade dele era sempre com italianos minha vó me dizia que tinha uma pessoa que vinha de perto da casa dele e é muito provável que seja uma única pessoa mesmo porque hã::: não tinha- não fazia parte do fluxo migratório né daquela região e eu acho que ele sempre se relacionou com italianos falando português com os italianos hã::: mas acho que foi muito difícil pra ele ser italiano porque ele pegou uma época muito difícil uma época ele atravessou duas guerras uma guerra onde a Itália não tinha um posicionamento muito claro e o Brasil também não então ele tentava ao máximo esconder a 
italianidade que era muito difícil porque ele era não parecia de jeito nenhum brasileiro ele era muito alto com os olhos claros então assim uma pessoa que chamava atenção de longe e se percebia que ele era estrangeiro eu acho que não foi que não foi fácil e não e acho também não foi fácil não poder voltar pra Itália ter que romper o vínculo definitivamente eu acho que foi muito difícil pra ele \#

22'04" G: Digamos não foi ele que quis

22'06" D: É ele foi obrigado a fazer isso hã::: então a gente vê que ele sempre tentava a \# hã::: como posso dizer ajudar a família na Itália principalmente depois da segunda guerra mundial ele mandava di- o pouco dinheiro que ele tinha porque era uma pessoa um trabalhador ele trabalhava na \# ai meu Deus fugiu o nome no Matarazzo na fábrica dos Matarazzo claro então ele era operário ele era hã::: ele trabalhava com caldeira trabalhava a noite toda então é uma pessoa que sempre trabalhou e lutou muito pra conseguir manter a família e ele tentava mandar um pouco de dinheiro pra família na Itália porque eles não tinham mandava comida mandava tecido mandava muito café pra eles é então nessas cartas que eu tenho tá assim ah vou me casar daqui não sei quanto tempo será que você não poderia mandar não sei o que então eles sempre pediam ajuda e ele sempre ajudou minha mãe falou me dizia minha mãe já morreu que ela se lembrava de quando ela era criança ir com os tios até o correio pra despacha::

23'17' G: I pacchi

23'19" D: É pra ajudar a família na Itália acho que ele se sentia no dever de fazer alguma coisa por eles.

23'26" S: É::: o que você acha que se pensavam dos italianos aqui no Brasil em especial em São Paulo como você acha que eles eram vistos aqui em São Paulo?

23'35' D: Que pergunta difícil

23'43" G: É é não essa é um pouquinho complicada no ponto da história né então assim

23'49" D: Eu sou um pouquinho influenciada né então eu não consigo já não penso nessa pegunta não consigo pensar só na minha família hã::: eu acho que até hoje a gente tem uma visão daquela época dos italianos que::: \# de uma Itália muito \# romântica de uma Itália que não existe mais me lembro de tá numa festa de::: Natal em Napoli e de final de ano de uma empresa e tinha um grupo de músicos napolitanos cantando algumas músicas que pra pra nós são super famosas e aí eu comecei a cantar as pessoas me olhavam e falavam mas como você sabe essa músicas nós não 
sabemos é música de mil do final do ottocento e eu falei ah tudo bem mas no Brasil ainda é assim são essas músicas de fes- dessas festas italianas eu acho que hã::: \# essa visão continua até hoje né bem marcada bem estereotipada mas tavez eles eu imagino também que eles tenham sido vistos como lutadores é a imagem que é o que eu imagino não sei se é verdade como pessoas trabalhadoras que::: vieram pra::: ganhar ganhar a vida construir a vida aqui no Brasil.

25'15' S: E é lido alguma coisa em italiano algum jornal algum livro você sabe?

25'20' D: Que eu saiba não que eu saiba não não era uma família muito culta é então eu acredito que não que não se lia nada se lembro meu avô eu levava pra ele alguns jornaizinhos Fanfulla mas que até acho que até já em português ou português italiano 25'41" G: Isso

25'43" D: Mas não tinha essa parte de leitura eu acho que era zero se a gente for tomar como base as cartas eles não seriam capazes de::: de::: de ler italiano.

25'59"' G: Então é isso né se você quiser complementar

26'05' D: Não acredito que

26'06' G: alguma coisa que você se lembre mas olha foi muito legal depois você edita esses

26'12" D: Que mais acho que é que é isso

26'15" G: É que as falas de de puxar né isso fica

26'20" S: Mas não tem problema também

26'23"' G: É sim só aquele início né

26'24' S: Tá

26'25"' G: Mas fantástico pode desligar 


\section{APÊNDICE D - Transcrição da entrevista 04}

03" E: Então muito /bem hã:: Ivamos começar a entrevista com o D. /A. obrigada D. por ter vindo

10" D: Obrigado por convidarem

12" E: Ah /e a gente\# tem aqui as >nossas perguntas e eu vou começar com a primeira delas e depois a gente vai conversando tranquilamente sem problemas< então a primeira pergunta é sobre as coisas é que a gente já estava um pouco comentando agora e o que você sabe de como a sua família ou as suas famílias >> você disse que são duas $<<$ vei- vieram ao Brasil

34" D: É eu sou descendente de italiano dos dois lados então que vamo- assim por partes a família A. que era do por parte do meu pai e a família D. que era por parte da minha mãe.

45" E: uhum

46" D: Eu convivi mais com a família A..

48" E: uhum

49" D: E se bem que:: nos últimos anos que meu avô <teve um AVC e ficou muito doente> da família $\mathrm{D}$. também tive um certo contato com ele ele era mais aristocrático 01'02' E: uhum

01'03" D: o outro era mais uma família de lavradores.

01'04" E: uhum

01'05" D: com quem eu tive mais contato os A.s entã::o eu me especializei mais nas minhas pesquisas pela família $A$. tanto que eu peguei a cidadania italiana po- por essa linhagem do meu bisavô avô pai e chegou até a mim.

01'20" E: uhum

01'21" D: Então o que eu descobri sobre os A.s? Eles moravam num município chamado numa cidadezinha chamada /Paese que é do lado de Treviso

01'33"' E: Treviso.

01'34" D: E.. tanto que saíram diversos A.s daquela região. [E: uhum] a /L. A. que é a única maestrina no Brasil e também é bem próxi- porque D. A. L. A. ela saiu também da região de Treviso mas de um outro lado como se fosse São Paulo São Paulo Osasco Zona Oeste São Paulo Guarulhos Zona Leste entã::o \# os A.s no caso do meu bisavô eles moravam nessa cidadezinha chamada Paese >que eu cheguei a visitar depois< continua pequena e:: segundo a minha tia que até eu consultei ela pra 
por causa desse trabalho agora dessa entrevista uma coisa interessante que eu nu::m sabia desse fato que eles saíram porque eles eram lavradores e eles plantavam melancias [02'27' E: ah] e na época teve uma:: epidemia muito grande e que matou muita gente e que o governo achou que era por causa da da melancia que que se proliferava na melancia e acabou com todas as plantações de melancia

02'45' E: Olha:: eu não sabia dessa história

02'47" D: É é tava\#

02'48' E: É a primeira vez que eu ouço essa história

02'50' D: É é eu também e que eles eram agricultores de melancia e o culpado na época foram as melancias que que a doença se propagava na melancia então isso foi a gota final de eles que /já eram muito pobres de pegar pensar de vir pro Brasil

03'06' E: Aham e isso aqui só pra nosso registro e então <mil oitocentos e oitenta e oito>

03'12'” D: Oitenta e oito quando eles embarcaram

03'14' E: Uhum que interessante ${ }^{\circ}$

03'15”' D: E aí o meu bisavô o L. A. ele era viúvo

03'23' E: uhum e ele era então já o filho que quem o chefe de família

03'27' D: era o L. 40 anos de 40 anos

03'29' E: ah era o L. ah sim que cê disse é

03'30' D: e que era viúvo

03'31'" E: certo

03'32' D: e aí ele veio como hum Ivamos ver na relação dos dos passageiros veio o L. com quarenta anos as filhas A. G. A. V. que era meu bisavô que veio com seis anos de idade Teresa que era a caçula da família quatro anos e/ por meu bisavô ser viúvo veio a sogra dele D. com setenta e seis anos de idade

03'58' E: 'Certo은

03'59' D: E aí eles embarcaram naqueles dados que eu de, e que vou fornecer pra vocês no passaporte é e:: vieram num navio chamado Berni Bearn até na minha pesquisa me confundiu porque o:: eles vieram em mil oitocentos e oitenta e oito e o Bearn era de mil oitocentos e oitenta e um sete anos era um navio relativamente novo 04'21' E: Sim

04'22' D: Porque existiu /outro/ navio com esse nome que aí depois me confundiu todo na minha pesquisa que afundou muito antes nas costas da Bahia

04'29"' E: Olha só que interessante 
04'31" D: Então esse já era o:: e o navio fazia duas viagens por ano comecei a pesquisar sobre o navio e ele vinha \# ficava ia voltava e na época no- na relação aqui depois do navio tinha essa pessoa Rodolfo Miranda hã:: que <era o agente que trazia os imigrantes aqui pro Brasil> era o responsável era o:: o captador vai eu não sei sei \# eles chamavam de agente

05'00' E: intermediário que fazia\#

05'01' D: isso isso isso

05'02' E: e e os /A./ fizeram o que quando eles chegaram no Brasil? Vamo primeiro ter- terminar essa fase deles depois a gente passa pros $D$.

05'10" D: Pros D. é\# que eu não sei tanto os A.s vieram pras fazendas de café já tava contratado porque era:: isso faziam lá:: na Itália

05'18' E: Então o contratado era o L.

05'20' D: L. com a família

05'21" E: porque a família eram todos eram crianças

05'23" D: isso isso isso

05'24" E: a D. veio pra cuidar das crianças

05'26" D: pra cuidar das crianças fazer a:: substituir a esposa né fazer a::a::o papel de cuidar da casa e cuidar das crianças

05'35' E: então eles foram para as fazendas no interior?

05'37'" D: /no interior/ \# hã de início eu achava que o:: que eles já tinham ido \# pra fazenda Amália a fazenda Amália era uma fazenda enorme dos Matarazzos na região de Ribeirão Preto que foi pra onde eles foram

05'53'” E: uhum\#

05'54" D: e que:: eu sempre me lembro do meu pai falando sobre a fazenda /Amália/ e que trabalhou na fazenda /Amália/ que ele era guarda-trilhos que até a história dos italianos né guarda-trilhos da fazenda Amália e ficava pô o que é um guarda-trilhos né Cê tem\#?

06'08'" E: Não

06'09' D: O guarda-trilhos é um garoto geralmente era um garoto que ficava andando toda a extensão do trilho pra ver se não tinha tronco se não tinha pedra pro trem não descarrilhar

06'19'" E: Olha só a::

06'21" D: E o meu pai quando fazia isso mas voltando e depois vamo voltar a falar\# 06'25' E: então eles não foram direto pra Ribeirão Preto? 
06'27' D: não foram pra fazenda\# pra fazenda Amália eu já com essa entrevista eu pesquisei melhor <eles foram hã pra::s casas de colonos de fazendas que:: uma delas a minha tia lembra o nome \# que era o nome de uma:: de uma planta assim no:: no momento não me recordo>

06'50" E: tá tudo bem\#

06'52" D: e:: mas eles ficavam aí perguntei bom mas aonde eles ficavam? eles ficavam na vila dos colonos italianos

06'56' E: hum...

06'58' D: que o:: o:: o governo se comprometia... o governo brasileiro se comprometia a fornecer habitação então era:: \# eles traziam os italianos ganhavam pouquíssimo mas eles eram obrigado a:: fornecer habitação que eram as famosas casas de colonos então <eles ficavam depois, quando eu pesquisei melhor agora \# eles foram trabalhando em diversas fazendas sempre de café algumas> assim por exemplo\# então vamo- vamo- vamos\# depois vamos voltar pra Ribeirão Preto\# algumas até na divisa de Minas Gerais

07'29'" E: hum

07'30" D: então não era uma coisa fixa ah chegaram ficaram na fazenda arranjaram dinheiro e compraram as terras muito depois \# eles economizaram e compraram a:: um sítio em São Simão que é um >município bem perto de Ribeirão Preto que é onde o meu pai nasceu minha tia nasceu essa minha tia que forneceu as informações nasceram< então mas de inicio eram outras fazendas e:: aí meu pai aí daqui meu pai foi trabalhar quando era garoto na fazenda dos Matarazzos então aí começa a italianada começa já a se:: entrelaçar

08'05' E: aham a interagir mas então a:: <<a primeira compra de terra que fez\#>>

08'12" D: terra foi em São Simão\#

08'13"' E: <<foi em São Simão?>>

08'13"' D: foi em São Simão

08'14" E: e ali eles começaram então a cultivar a terra ali?

08'16" D: sim\# e aí ali já terra própria e dali mais tarde o meu pai que era o mais arrojado de todos os filhos e não era o mais velho mas era ele era bem jovem com dezoito anos ele não se acostumou com aquela vida de:: de lavrador tudo ele queria alguma coisa melhor e veio pra São Paulo aí começou aquela epopeia aqui:: aí depois voltamos à história dele o que aqui em São Paulo o que é no que é que ele trabalhou e depois ele foi trazendo todos os irmãos e os pais 
08'49' E: A:: então foi toda a família que veio pra cá?

08'50" D: Ele/ que trouxe ele se- ele- ele que foi o pioneiro né na segunda virada na primeira o meu o\# seria o::\# o pai\# o pai o avô dele né veio da Itália e depois o fi- o neto veio pra São Paulo

09'06”' E: Pra São Paulo

09'07' D: ํE aí eu nasci aqui em São Pauloo

09'09"' E: /Hum\# então muito bem então agora vamos pros D.

09'12" D: /Os D.\# los D. já é uma história diferente já os D. hã \# enquanto os A.s eram agricultores os $D$. trabalhavam com mármore desde lá eles vieram da região de Carrara\#

09'23" E: Ah era essa a história\# uhum\#

09'25' D: Vieram da região de Carrara então o:: já eram mais não digo aristocráticos porque naquela época as diferenças de classes eram bem definidas mas eles tinham MAIS posses do que os A.s então\#

09'41" E: E por que que eles vieram?

09'43"' D: Também pra- por causa de trabalho

09'45" E: De trabalho mas aí eles eram mais aristocráticos mas não tava indo tão bem na Itália?

09'49" D: Não tavam indo tão bem então vieram pra cá e o meu avô G. D. o pai da minha mãe veio pra cá e começou a trabalhar como- com pedra também tanto que o:: aquele monumento do:: Ibirapuera o:: a:: da:: da estátua lá \# foi ele que forneceu o granito e que na época como a eles chamavam de canta-guia né hoje em dia é marmoraria mas a a:: oficina das pedras deles era no Canindé perto do estádio da Portuguesa as pedras saíam dali da região do Canindé e iam até o lbirapuera em caminhõezinhos que não existia pneu com câmara era de borracha maciça o pneu e:: /por que? porque meu avô por ter (não entendi xxxx) um nível até cultural diferente ele era amigo do::s dos escultores italianos daqui de São Paulo no caso o Brecheret que fez o monumento então como era todo- todo eram todos amigos então ele conseguiu fornecer a::s pedras

10'53' E: Então eles vieram e ficaram aqui em São Paulo?

10'56" D: Vieram já também pra São Paulo

10'57'” E: São Paulo 
10'58' D: São Paulo /pra região do Bom Retiro que tinha u::m que na época era também um bairro tinha um núcleo de italianos e depois foram por causa de ficar perto da oficina de:: da marmoraria tudo foram pro Canindé

11'13" E: Hu::m \# essa história é uma história já muito menos comum sabe? Acho que é a primeira vez que alguém conta /é sim porque acho que marmoraria sim alguém que fosse espé- acho que num- né num- é a primeira ainda não ouvimos

11'24" D: É que vieram e faz sentido porque já eram da região de Carrara

11'27" E: Sim sim \# então \# Tinha os /contatos\#

11'30" D: É é o que eles sabiam fazer né e já vieram pra cá e::

11'33" E: é eu já tô imaginando como era trazer o /mármore que era grande devia ser interessante essa história

11'39" D: E e ficaram /bastante nessa \# nesse trabalho tanto que quando eu era pequeno o:: meu avô já tinha tido o AVC já tava doente tudo mas era uma coisa bem recente falava ó aqui que passava na porta de um- do prédio onde era a marmoraria e é engraçado que esse meu avô os De- do D. construiu uma /série de:: de sobrados ali no bairro do Canindé que é onde onde eles ficavam e recentemente um dos sobrados foi vendido e antes disso foi reformado e tal \# hã:: o meu irmão que é arquiteto o Décio ajudou pra ver a reforma onde é que podiam mexer tudo a base da casa era de caco de granito e mármore

12'26' E:<< Olha>>

12'27' D: É uma base uma base chique né de:: (risos) uma base de:: a:: /a fundação toda a fundação que é pra umidade naquela época do:: que tinha o porãozinho embaixo pra arejar era tudo de caco de mármore e granito que saía da marmoraria mas é um\# é chique né\#

12'43' E: É super (risos) super chique

12'45" D: E aí depois nas outras perguntas nós vamo ver o:: então inclusive o nível intelectual de uma família e de outra que era bem diferente coisas interessantes

12'53" E: Que legal é porque aí a nossa próxima pergunta é é:: bom a gente já viu que eles então que a família $D$. veio diretamente pra São Paulo

13'01' D: Isso isso

13'02"' E: A família A. foi primeiro pro interior e depois\#

13'03"' D: Pro interior pra agricultura 
13'05' E: vieram pra São Paulo mais tarde então a outra coisa que a gente:: que era interessante a gente ver se você lembra é se eram contadas histórias sobre a Itália tanto na família sobre o que acontecia antes deles virem pra cá ou-

13'20"' D: A família A. hã:: ela se adaptou ao Brasil ela introjetou o Brasil muito mais do que a família D. tanto que hã:: essa parte de /música hã:: ler jornal que era uma das coisas\#

13'33'" E: Uhum

13'33" D: Era muito mais do lado D. que era um lado mais intelectual que eles liam Fanfulla e:: ouviam ópera enquan- era interessante porque assim isso daí até meagora que eu tive essa visão enquanto os D.s /liam o jornal hã:: ouviam ópera que todo o meu a minha base de ópera veio dos D.s que acostumados a ouv- e depois minhas tias tudo os /A.s <nessa conversa que eu tive com a minha tia> o meu avô Valentino aos 12 anos ele começou a aprender sanfona na:: na fazenda

14'04"' E: Aham

14'05"' D: E aí é:: tocava uma sanfona pequenininha de criança de oito baixos

14'09'" E: (risos) que legal

14'11" D: E:: e assim ele /criança \# pelo que agora o:: eu consegui saber ele criança a noite /depois de tudo da do:: do trabalho tudo ele ia no meio do milharal e ficava treinando sozinho

14'27' E: Ó:: olha que interessante

14'29" D: E aí ele cresceu <aprendendo as músicas folclóricas italianas< que é a tradição

14'35' E: A:: certo

14'36" D: Mas de ouvido

14'37' E: Hum\# mas essas músicas com as outras pessoas ou era uma um quadro da família

14'42" D: Foi passando veio passando aí é:: segundo também hã:: me contaram chegou uma hora que ele aprendeu o que tinha que aprender aí ele ia pra São Simão no- pra assistir um filme que na época era cinema mudo

14'56"' E: Hum \# ele tocava?

14'58' D: Não pra ouvir as músicas que tocavam \# no cinema porque o repertório dele já tinha esgotado e ele queria saber mais \#

15'04"' E: (risos) 
15'05" D: Então\# aí eu fico imaginando porque assim ele ia pra ouvir a música e que aí ele começou a ter contato com valsa co::m xote com todos os outros ritmos /aí voltava e tentava reproduzir

15'19"' E: Olha que interessante

15'20' D: Então voltando enquanto os D.s ouviam ópera os outros os A. já era música mais italiana folclórica e aí meu avô se deu tão bem que depois <foi crescendo ficou\# que depois ele $>$ nas fazendas até nós temos depois conhecidos que falavam $<<a h$ veio::- quem animava as festas na nossa fazenda era um tal de Valentino que é meu bisavô e aí ele ficou indo /anima::ndo as festas da fazenda

15'54" E: Entendi olha que interessante e histórias assim ou hábitos italianos cê lembra se tinha alguma coisa assim pra:: além da comida lou de porque assim eles ouviam música mas contavam alguma coisa de antes de virem pra cá? Não sei\# -alguma história ${ }^{\circ}$

16'10" D: É tem uma história bonita do::também desse do meu bisavô o Valentino que quando\# ele ele veio com seis anos e quando eles saíram de Paese e pa- e talvez seja naquele um dia que ficaram em Génova esperando o:: o navio pra:: pra embarcarem no navio hã:: teve um almoço que é do \# ${ }^{\circ}<$ entre os que ficaram lá os parentes que ficaram lá um parente que devia ser um\# era um tio $>^{\circ}$ um tio deu um almoço no caso pro L. que era meu bisavô e foi o meu avô pequenininho foi lá e:: eles deram um cálice de vinho um cálice pequeno de vinho a uma criança de seis anos né deram o cálice e o meu bisavô ficou meio tonto né e tem uma história bonita porque depois <quando eles foram saíram do restaurante e foram indo provavelmente em direção ao porto> tinha no final de uma rua na esquina que era muito comum e ainda até hoje na Itália ter a imagem de uma santa que protege o bairro o:: a rua \# e aí meu bisavô falou olhou pra santa já meio tonto por causa do vinho e falou addio madonna e <foi um adeus mesmo porque nunca mais ele voltou $>$ então com seis anos ele tinha consciência\#

17'33"' E: Aham \# certo que estava indo pra não voltar ${ }^{\circ}$

17'35' D: Que tava indo pra algum lugar lentão isso daí é muito bacana

17'39" E: Interessante \# e:: então não se falava muito da Itália pelo que eu tô entendendo

17'45" D: Não a:: a família A. não s- os D. eles contavam mais algumas histórias tipo que uma:: uma eu não sei se era\# hã:: seria uma parente da minha- do meu bisavô né do meu avô de que ela trabalhava em um dos palácios de Veneza como criada 
como dama de confiança de uma das da::s das damas das duquesas de Veneza né então a gente já vê que mesmo sendo dama de confiança tudo já é um /nível melhor que os agricultores né

18'23"' E: Uhum\# entendi interessante é:: hum \# ah bom temos uma pergunta sobre a língua né se se falava

18'31" D: Os D.s falavam os D.s é- toda a parte de língua que eu tenho que eu peguei de ah... de falar um provérbio:: em italiano uma expressão final em italiano foi da parte dos D.s eles mantiveram \#

18'46" E: Entre eles >eles falaram italiano durante um tempo?<

18'48' D: Entre eles sim sim sim sim \#

18'50' E: E os A. não?

18'51" D: Não os A. não

18'52" E: Nem nome de /comida?

18'53"' D: Ah não sim é \# os A.s toda assim comida:: costumes eles eram bem italiano mas não puxavam isso daí da da língua em que a:: \# porque na Itália \# eles não eram muito saudosistas eles se adaptaram perfeitamente vamo \# vida nova \# vamo vamo vamo pra frente e pronto né tanto é:: a histório do:: imigrante mesmo eles falam <bom agora que virou a página $>$ os $\mathrm{D}$. eram mais\#

19'23'" E: Ligados à origem \#

19'24" D: Ligados é \# e teve casos na família como um tio meu que ele morava no::aí já é outra família Vanucci né:: to- toda a minha família todos os lados eram todos italianos o Vanucci esse meu tio que eu conheci bem convivi bastante com ele <ele também ele \# ele assim é:: apagou a Itália porque:: ele morava no Brasil foi pra Itália a pedido dos pais e foi convocado pro exército> e ele chegou a ser o\# camisa preta dos fascistas contra a vontade do Mussolini camisa preta \#

20'02' E: Então ficou com ódio pra sempre?

20'04" D: Não voltou\# então ele apagou é o mais brasileiro de todos os tios ele nasceu na Itália então\# então cada caso né era o\#

20'13" E: Sim sim se desenvolveu de uma maneiraํ-

20'14" D: Mas em todo- por exemplo dos D.s o que é qual foi a minha herança cultural música ópera o gosto por vinho o gosto por gastronomia italiana tudo então era mais (não entendi $x x x x$ )

20'25"' E: Tipo o almoço de /domingo? 
20'27' D: É isso não tinha os almoços de os almoços de fim de ano na casa desse meu avô o:: G. D. é \# hum \# foi se reunia umas dez mulheres pra preparar e era assim era o dia inteiro que servindo coisa e co- almoçando comendo eu era garoto mas eu me lembro era um verdadeiro banquete né e tudo feito na hora era sacrilégio comprar alguma coisa pronta né\#

20'56" E: (risos) Ah claro sem dúvida é:: \# Ideixa eu ver \# então bom /a gente já disse que mas a:: hoje em dia não tá mais ninguém falando italiano da tua família? Nem a /tia::? Essa que mora em Santos

21'10"' D: Não não não não não em Santos não não nenhum\# nos dois lados ninguém tá falando italiano

21'17' E: Ninguém passou italiano pros filhos pros netos nunca mais se falou então isso \confirma os nossos dado que é o que mais aconteceu\/e aí tem uma coisa uma uma uma das coisas que que a gente se perguntou é:: é como essas pessoas sentiam o ser italiano em São Paulo? Se havia algum tipo de\# é:: se como as pessoas como os outros que não eram italianos viam os italianos em São Paulo cê tem algum tipo de lembrança sobre isso? Algum comentário que é feito na família?

21'53" D: Ó isso eu sei que- tanto dos D. como do A. apesar dos A.s também não não levarem a:: a tradição /tão assim a ferro e fogo mas eles só se conviviam entre eles e era só eram só os italianos e saíam /pra: viajar tudo e só\# era uma\# ou seja era uma comunidade bem fechada assim dos italianos e aí teve a:: o\# o começo de vida do meu pai aqui que o meu /pai é \# saiu de lá com os 18 anos veio pra São Paulo foi mil coisas desde lavador de /janela até tudo\# até ele foi ir trabalhar na fábrica dos Filizolateve fundição e aí ele foi trabalhar na fábrica dos Filizolas outros italianos e das balanças Filizolas e aí\# foi interessante porque assim /toda aquela linhagem vinha da agricultura e o meu pai que era um rapazinho na época foi trabalhar no Filizola e vendo uma indústria começou a ter gosto pela indústria uma pessoa que poderia ter sido /ah foi foi ser fazendeiro foi ser outra coisa- comerciante porque ele teve padaria não deu certo teve fundição não deu certo e entã::o ele:: na Filizola despertou um\# uma vontade de ter indústria depois de duas ou três tentativas ele fundou a:: indústria de máquinas que eu fiquei administrando durante trinta e cinco anos e é interessante porque assim uma pessoa que vem de uma:: linhagem /só de agricultores de repente que é isso aí também é comum do:: dos italianos ter o gosto pela \# pela indústria e projetar máquinas assim que /até quando eu encerrei a empresa agora há poucos anos depois de cinquenta e oito anos de indústria no final as máquinas hã:: que eu 
fabricava \# claro eram muito mais modernas mas eram os fundamentos os mesmos fundamentos que ele projetou e de uma pessoa que não tinha na família não tinha na/nenhum \# né fala bom puxou o dom de tal tio ou não tinha e ele /tinha uma cabeça pra mecânica tanto que eu convivi com ele muito quando nós administramos juntos a indústria ele chegava pros projetista e falava <olha faz isso faz isso trarara> aí os projetistas executavam porque ele tinha muito pouca escolaridade mas ele falava pros projetista do jeito que tinha que ser da mecânica o funcionamento das engrenagem umas coisas bem sofisticadas mesmo aí os projetistas fã- hã- desenhavam mandavam pras máquinas e faziam então ele tinha esse dom de- da mecânica

24'51' E: É talvez algum outro membro da família /tinha e não tinha sido descoberto porque sempre se- não tinha tido a oportunidade talvez \#

24'57' D: É \# é é e ele adorava mecânica mesmo tinha um- não teve um /background assim de /mecânica de /mecânicos na família né foi um uma coisa que começou com ele e depois eu continuei

25'10' E: A:: \# que interessante \# e como você acha que /eles ou que os italianos /eram /vistos ou são vistos? Cê \# se você tivesse que escolher três adjetivos pra dizer como que os italianos são vistos no Brasil em São Paulo se \#

25'24' D: Ah muito bem vistos eu acho que que:: assim sempre \# sempre o o meu /pai ou então tanto da outra parte dali sempre tiveram sucesso no que eles fizeram porque:: a... a lépoca que ele viveram São Paulo a grande parte era italiana ou espanhol ou dos espanhóis né então eles sempre tiveram portas abertas assim /nunca tiveram problemas /de:: ah o:: \# por serem imigrantes ou serem filhos de imigrante eu acho assim eles eles /tinham um sentimento não sei nunca expressaram isso pra mim mas eles tinham um sentimento que construíram São Paulo tinham mesmo assim e que /essa cidade era deles assim eles que construíram eles que ajudaram a erguer porque na /época todos assim as as mansões a:: as casas da Paulista ou pelos bairros vai onde eles moravam aquelas vilas dos italianos era tudo de de amigos dele de parente ou de conhecidos então /era a cidade que eles ajudaram a construir

26'32' E: Então aquela imagem dos italiano trabalhadores...

26'35' D: Sim sim mas ao mesmo tempo alegres assim porque tinha tanto dos dois lados também hã:: \# o:: assim /podia ter a maior crise mas dia de festa era dia de festa dia de viajar era dia de viajar hoje mesmo já nos tempos modernos eu que já eu fiz administração de empresas tiveram assim quando nós que estamos passando as /maiores crises meu pai falava <bom amanhã eu vou viajar> falava <pô mas como 
assim amanhã vai viajar?> <não não não que amanhã vou viajar que eu já combinei com meus amigos> então tinha isso daí era um- de uma vida também alegre não era uma vida amargurada eu acho assim dos dois lados nunca tivemos problemas de\# a:: tal pessoa é muito fechada pelo menos não nas duas famílias tal pessoa é muito fechada muito amargurada sempre um povo trabalhador meu pai era trabalhador demais assim né ficou \# tanto que quando meu pai no final que ele já ficou muito doente um dia- nós ficavamos conversando muito e ele falou <nunca eu me lembro de uma época que eu não trabalhei desde pequeno> porque nasceu na:: no interior desde pequeno as crianças que nascem em sítio ou em fazenda já ajudam a fazer alguma coisa então vai cuidar das galinhas vai vai fazer- então meu pai falou <Eu nunca me lembro de uma época que eu não trabalhava> mas ao mesmo tempo aproveitou /bem a vida muito a vida \# aproveitou muito muito

28'04" E: Certo que legal e aí então aque- aquela última pergunta que temos que é sobre a:: o:: o jornal né você falou do Fanfulla mas ele só um detalhe assim cê já falou mas só um detalhe você /lembra de eles com de eles lerem em casa? Ou eles liam talvez em associações?

28'22' D: Não o meu tio o meu avô D. ele assinava ele lia em casa e ligava o rádio e ouvia os programas de rádio em italiano e principalmente ópera em italiano

28'38' E: Os /A. nada?

28'39' D: Os A. não os A. não

28'40' E: Hum \# porque assim uma uma outra coisa que se /fazia era ler o jornal na /associação e:: em reuniões \#

28'48' D: Ah o:: que eu me lembro agora que eu me lembrei tanto dos dois lados o esporte deles que era assim ah o domingo era sagrado era boccia

28'50' E: IAh tinha entã::0

29'00', D: A boccia né \#

29'01' E: A boccia \#

29'02' D: Que é tipicamente italiano né::

29'04' E: Sim sim então tinha um clube ou alguma coisa assim?

29'06' D: Sim sim meu pai /meu pai quando era e o meu avô também porque meu pai se\# se dava muito bem com o:: com o pai da minha mãe o sogro dele /muito bem mas o tanto que o sogro dele meu avô J. D. ajudou o meu pai quando- pra /pagar a primeira casa e tudo né e os dois eram /muito amigos né até o meu:: avô ter o AVC o sogro dele ter o AVC e eles iam de manhã domingo de manhã eles iam jogar /bo::ccia 
então e a desculpa também pra tomar um vinhozinho antes de chegar em casa e a mulher não dar bronca essas coisas todas aí

29'41' E: (risos) que legal ótimo

29'43" D: Eu tenho uma lembrança também nós estávamos falando de lembrança do::s dos italianos eu já cheguei a comentar com você mas pra deixar registrado perguntei pra minha tia há algum tempo atrás foi qual a /primeira lembrança que a senhora tem de criança? (Não entendi) Eu tenho umas lembrança todo mundo tem uma lembrança um primeiro fragmento de memória e ela falou <a:: me lembro de um dia uma tarde de sol tipo meio dia uma hora hã:: no sítio \# e que todos os colarinhos das camisas tavam sendo quaradas" porque no domingo tinham ido na missa> e a cao colarinho saía

30'21' E: aham

30'22' D: Da camisa porque era o que sujava mais nas estradas de terra do interior $<$ e tava- me lembro todos to::dos os colarinhos pendurados e olhava aquele banco branco assim fiquei espantada de ver o aquilo tão branco as tirinhas de pano dos colarinhos> falei nossa é legal né:: bem\#

30'39" E: interessante essa coisa de ir bem vestido pra missaํำ

30'42' D: É é sim sim né de:: de viajar de andar não sei quantos quilômetros \#

30'47' E: Pra chegar

30'48' D: A cavalo na época né pra chegar até a:: a cidadezinha que era São Simão e:: ou ir na festa também né nas festas que tinha lá né e tudo

30'59' E: Bom nossas perguntas acabaram se você quiser falar mais alguma coisa 31'04" D: Eu acho que basicamente é isso mesmo falamos sobre as duas famílias falamos sobre o:: \# o navio as condições que eles vieram pra cá ah ah sim tenho uma memória também do meu pai quando ele >já tava muito quando ele ficou doente muito saudoso assim< que ele falava uma vez nós távamos agora que fazem ele faleceu em noventa e um então isso deve ter sido em mil novecentos e noventa nós távamos voltando de um dos- de um dos médicos dele de carro e ele falou né nossa como vão mudando as coisas né quando:: nós saímos do interior pra vir pra São Paulo ele falanfalando nós acho que não tava se referindo a vinda dele mas a fami- a vinda da família né dos pais e tudo ele::s colocaram tudo num caminhãozinho ele falando ah e nós trouxemos umas telhas de zinco que talvez precisasse é \#

32'00' E: (risos) 
32'01' D: É então não é:: era assim era penúria mesmo era:: bom vamo::- é isso que eu admiro vamo pra vamo ver vamo pro que der e vier assim e não era assim ah uma coisa planejada era se atirar na vida mesmo

32'15' E: Uhum \#

32'15" D: Desde da Itália pra cá como do interior pra /São Paulo era sem preparo nenhum vamo ver o que /dá e pronto

32'23" E: E com alegria?

32'24" D: E com alegria com alegria

32'27' E: Muito bem \# então D. muito obrigada

32'30" D: Obrigado eu que agradeço o convite e foi bom deixar registrado \# 32'33"' E: Legal

32'34" D: as memórias da família muito obrigado vocês

32'36"' E: Ótimo. 


\section{APÊNDICE E - Transcrição da entrevista 05}

08" E: Boa tarde estamos aqui com o professor J. A. que agradecemos por ter vindo aqui contar um pouco da história da da sua família \# então nós hã:: podemos começar talvez com a pergunta do que que você sabe sobre a sua famí::lia de onde eles vieram pra onde que eles foram no começo essas coisas \#

30" J: Posso dizer duas coisas primeiro que eu sou a única pessoa da família dos descendentes que se interessa por isso \#

37" E: Ó:: interessante \#

39" J: É:: sobrinhos e outros parentes parece que não querem muito se interessar pelo passado \# a segunda coisa é que eu sou de uma família multicultural pelo lado de pai de descendência italiana e portuguesa que é por isso que eu tô aqui por parte de mãe alemã e francesa então é essa parte italiana da família foi a que pra mim ficou mais é digamos assim impregnada né foi aquela com a qual eu mais me identifico então

01'16" E: Mesmo você sendo professor de alemão

01'18' J: Mesmo eu sendo professor de alemão (risos) porque aí foram outras circunstâncias que me levaram a isso né mas eu fui criado praticamente pela minha avó italiana então isso pesou bastante nessa formação né minha mãe trabalhava fora meu pai trabalhava fora também e eu ficava quase o dia todo com minha avó e quando ela morava numa casa ainda pequena perto da casa da minha mãe a gente ficava ouvindo ópera italiana foi através dela que eu conheci (não entendi o nome) quer dizer uma coisa que é que já fazia parte digamos da família dela que era no fundo uma família muito simples

02'02' E: uhum

02'03" J: E a família enorme como você pode ver aqui nessa fotografia

02'08' E: uhum

02'09”' J: Minha vó M.

02'10" E: Essa é sua avó

02'11' J: Minha bisavó M.

02'11' E: Ah essa é sua bisavó

02'13' J: Meu avô V. minha avó C. que é essa daqui os outros é sete filhos são é são oito filhos no total cinco homens e três mulheres deles não há mais ninguém vivo hã essa é uma cópia que eu vou doar pro projeto 
02'32'" E: Ah que legal

02'33" J: da fotografia eu tenho mais uma outra eles vieram de uma região da Itália da Calábria eram camponeses vieram de Cosenza-Catanzaro e vieram é pelo que eu sei diretamente para a cidade de Ribeirão Preto para trabalhar lá na lavoura de café 02'54" E: Você sabe quando que foi isso?

02'57' J: É:: pela certidão eu imagino que minha vó já nasceu aqui é:: ela nasceu em 1908 já aqui no Brasil filha deles então foi no início do século XX né ou um pouquinho talvez

03'13' E: E quem veio foram o o- \#

03'14" J: O casal já com algum filho mais velho que eu não me lembro que nasceu na Itália ou no trajeto de navio né e o resto da família nasceu mesmo em Ribeirão Preto trabalharam durante muitos anos não só na lavoura de café mas também acho que aí tem uma coisa interessante que é uma transição pra vida urbana minha avó por exemplo ela ela trabalhava nas indústrias Matarazzo lá de Ribeirão Preto e trabalhava na parte têxtil né e depois que ela se casou com o meu bisavô com meu avô português a certidão de casamento tá aqui até pra provar o vínculo com meu nome porque meu avô português tem o mesmo nome que eu tenho era da região de Loureiros como ele retornou pro pra Portugal muito cedo porque ele ficou doente quis morrer em Portugal a minha vó teve que voltar pra casa da família italiana já com meu pai com três anos de idade e passou a exercer uma atividade de bordadeira pra fora e e foi assim que ela ficou até o segundo casamento que foi bem mais tarde então o meu pai foi criado digamos pelos tios tias e pela minha avó italiana

04'39"' E: Hum entendi eles escreviam C. com dois éles

04'45' J: hã:: deixa eu ver se tá \#

04'47' E: C.

04'48' J: isto

04'49" E: e assim ficou? C. ficou com dois éles?

04'51" J: Ah sim \# ficou com dois éles

04'53" E: E seria um só é e são aquelas coisas dos cartórios

04'56" J: É:: não inclusive aí tem que se dizer é quando eu tentei fazer um levantamento do da origem da família com alguns dos tios do meu pai ainda vivos principalmente com essa que era a $\mathrm{C}$. ela ficou muito constrangida eu pedi pra ela documentos dos avós etc e ela ficou muito constrangida depois o meu pai ela disse que não tinha mais nada que tinha queimado tudo e aí meu pai uma vez me chamou 
e constrangido também e disse que era possível que meu avô já fosse casado na Itália antes de vir pro Brasil o que era uma coisa bastante hã::

05'38' E: não se podia

05'39'” J: comum

05'40', E: ah era comum

05'41'” J: era comum

05'42' E: mas eles vieram juntos?

05'44" J: vieram juntos é é \# vieram juntos pra cá\#

05'47' E: E você falou Cosenza Catanzaro porque um era de Cosenza e outro de Catanzaro?

05'51' J: E o outro de Catanzaro isso é o que eu sempre ouvi na família agora não sei quem era de onde qual dos dois né::

05'58' E: Porque assim os documentos deles então::

06'00' J: Desapareceram

06'01' E: Estão todos perdidos

06'02' J: Desapareceram é eu tentei levantar algumas poucas coisas com essas referências que aparecem aqui e eu acho que na certidão de nascimento do meu pai tem a referência à Cosenza Catanzaro do V. M. e C. C. que eram

06'20' E: São os pais da sua avó?

06'21' J: É::

06'22'” E: Que são seus bisavós?

06'23' J: São meus bisavós \# exatamente

06'25' E: Uhum \# entendi \# ah ó que interessante aqui C. tá com um éle só 06'28'” J: Pois é \#

06'29'” E: Tá certo talvez tenha sido um erro desse próprio documento 06'32'” J: É:: pois é:: pode ser

06’34’' E: É:: e:: e:: eles então você me falou vieram diretamente para trabalham em:: 06'39" J: Vieram diretamente pra lavoura de café e o trabalho nas indústrias Matarazzo que em Ribeirão Preto era uma:: uma indústria enorme muito bem desenvolvida o prédio existe até hoje tá abandonado mas existe até hoje \# 06'53' E: Mas isso começou já com o seu bisavô? Ou foi com os filhos dele? Trabalhar nas indústrias \#

06'59' J: Nas indústrias a minha avó já trabalhava quer dizer eu- eu não sei dizer eu não tenho memória para dizer se o meu bisavô também era- chegou a fazer isso ela 
minha bisavó que eu sei que minha mãe também contava porque chegou a conhecêla ela ficava mais em casa porque tinha oitos filhos e a L. ou L. que essa pequenininha era uma pessoa doente ela tinha- ela desenvolveu uma obesidade mórbida e não podia fazer nada:: e tal

07'30" E: Então a avó ficava cuidado dos filhos

07'32'" J: A:: a mãe ficava cuidando dela

07'34' E: Quer dizer a bisavó sua

07'35" J: A minha bisavó ficava cuidando dela com a ajuda da C. também que hã acabou não se casando e se tornou digamos assim aquela que cuidou de todos os irmãos solte::iros e etc que ficaram \#

07'51" E: Mas não tem uma história de eles da lavoura terem passado para outras atividades?

07'56" J: Não \# eu tenho a impressão de que basicamente eles já- já vieram para se estabelecer na cidade talvez eles tenham desenvolvido algum deles os os mais velhos no início alguma atividade lá nas- nas lavouras de café que por sinal também fazem parte do lado alemão e francês da família da minha mãe né

08'20"' E: Uhum

08'22' J: É:: o meu bisavô era francês e ele trabalhava na fazenda Monte Alegre onde hoje é a USP

08'31' E: Uhum

08'33' J: Que era do Schmidt

08'35' E: Hum \# interessante essa parte

08'36" J: Então toda a minha \# minha história tá ligada a esse \#

08'40"' E: A essa vinda

08'42" J: Essa vinda para trabalho em lavoura e tal e tem uma transição é:: da:: do campo pra cidade que aí no caso na geração da minha mãe e do meu pai se consumou completamente aí ninguém mais quis saber de voltar \# né \# sair da cidade então aí começa a história dos empregos públicos servidores etc que é- hã- mas aí já na geração do meu pai e da minha mãe

09'13"' E: Certo \# E você disse que você cresceu com essa sua avó italiana

09'17' J: Boa parte da minha infância

09'19" E: E você lembra de alguma história sobre a Itália que ela contava?

09'23" J: Ela- ela mesma nasceu em Ribeirão mas ela ouvi::a as coisas que a mãe provavelmente dizia né \# essa parte eu tenho uma memória muitíssimo vaga eu sei 
que ela trouxe com ela- a família trouxe com eles uma série de discos como eu falei e coisas assim que eu falei que apontam para uma vida simples na Itália mas também com alguma- algum traço cultural um pouquinho mais forte né::

09'52' E: Ah sim

09'53' J: mas o que ela- a memória que eu tenho é de uma formação muito severa assim muito severa do ponto de vista:: do controle de horário de comi::da né eu acho que o que aconteceu foi que a geração dos filhos é \# na qual eu me incluo é- evoluiu digamos assim muito rápido e minha avó viveu até os oitenta e oito anos com muita saúde então criou-se aí um- ligada à valores digamos assim da Calábria do final do dezenove então criou-se aí uma certa é \# crise de gerações que é:: acabou se consumando bastante numa disputa entre ela e minha mãe que minha mãe que tem um lado alemão e francês muito mais forte ela queria sempre os filhos \# é:: pra frente na cidade fora dessa história de roça etc então é:: eu acho que aí se criou uma umconflito mesmo de gerações então as histórias que ela me contava eram histórias ligadas assim à atitudes morais à obediência aos pa::is um contato também grande com a questão da natureza mas sobretudo em contraposição a parte francesa e alemã da minha família que também é muito forte e:: ela tra- trazia u::m uma relação afetiva muito mais \# sincera \# então era bem diferente esses dois lados

11'40" J: O lado dela por exemplo isso foi até o final da vida era de uma coisa assim de sentimento declarado não gosto não gosto gosto gosto então vem abraça beija aquele beijo molhado e aquele abraço apertado e aí gosto tanto de você que parece que você saiu das minhas entranhas \# isso eu me lembro perfeitamente porque ela me dizia mui::tas vezes

12'05' E: E ela falava português?

12'06" J: Ela falava português mas assim misturado com o italiano em vá::rios momentos \# tanto que o que eu sei- o pouco que sei de italiano eu aprendi com ela que ela é:: no convívio comigo muitas vezes na::s questões do dia a dia do cotidiano falava em italiano

12'23' E: Ah \# falava em italiano mesmo?

12'24' J: Falava em italiano só que já era- imagino que fosse aquele italiano já

12'28' E: Dialeto e misturado?

12'30' J: Dialeto misturado já com o portuguê::s e etc mas as poucas coisas que eu lembro não são tantas assim vem dessa convivência com ela:: \# de alguns anos né porque minha mãe sempre trabalhou fora e meu pai também 
12'46" E: Uhum \# então isso significa que seus avós- seus bisavós talvez conttivessem continuado a falar italiano (não entendi) em casa

12'54" J: Isso muito provavelmente entre eles \# muito provavelmente entre eles e imagino também que fosse uma:: relação muito fechada porque minha avó foi a ú::nica pessoa de todos esses oito filhos que realmente se casou e saiu de casa \# todos os outros tiveram companheiras mas nunca tiveram uma relação separada eles tinham uma relação muito forte entre eles então eu imagino que eles fossem uma família assim fechada e que entre eles falassem italiano

13'29" E: Falava italiano \# E eles tinham nessa- em Ribeirão Preto outros amigos italianos? Outras famílias italianas?

13'34" J: Não que eu saiba não que eu saiba porque as pessoas que se lembram dele até hoje eles moravam na rua Pompeu de Camargo uma rua que existe até hoje lá e eu passo sempre de carro pra ver se a casa ainda existe mas a última vez que passei eu vi que já não existe mais tinha um jardim grande com a casa bem ao fundo e não existe mais a casa lá é:: mas as pessoas que me falam deles são todas brasileiras assim não tem ninguém de origem italiana \#

14'06' E: Uhum

14'07' J: Eu não sei como funcionava dentro da empresa Matarazzo se ali eles tinham alguns conhecidos mas como digo pra você sempre me pareceu e até hoje me parece que eles eram uma família muito reservada.

14'21" E: Uhum (Não entendi)

14'22'" J: De poucos amigos

14'24" E: Uhum \# então você não teria memória de como é que era ser italiano no Brasil nesse momento se tinha alguma:: característica assim que as pessoas em volta atribuía aos italianos?

14'37' J: \# é:: eu eu acho que não tenho assim- eu tenho uma intuição de dizer pra você que:: é:: eram pessoas que viviam realmente divididas entre um mundo eu nunca fui à Calábria eu não conheço mas entre um mundo de realidade rural com outros valores e um mundo urbano de uma cidade em constante modificação.

15'05' E: Uhum

15'05" J: É:: quando à opinião dos outros sobre eles é difícil pra eu avaliar eu numeu num tenho isso porque as avaliações que eu ouço deles de outras pessoas na minha memória da minha família mesmo da parte alemã e francesa e de outras é 
conhecidos amigos da minha mãe que conheceram é de que eram pessoas muito simples \# que quase é:: acho que:: hã:: um deles nem sabia escrever \# 15'36' E: Uhum

15'37' J: Entã::o isso era digamos assim digo até de uma certa vergonha \# né:: porque:: eu- eu sei que minha avó sempre criticou muito essa essa atitude de você avançar avançar avançar sem \# é voltar para os valores primordiais de mã::e pa::i etc e tomar benção que é uma coisa que hoje é praticamente ninguém faz [E: uhum] num é? e:: todos os almoços sempre tiveram que ser na casa dela no dia primeiro do ano e tinha que comer tudo que ela punha na mesa e era muita coisa e a gente não aguentava e ela ficava brava

16'19' E: E a comida era italiana?

16'20" J: A comida era italiana ela fazia a massa na casa dela ela fazia todas as coisas que precisava para uma deliciosa macarronada na casa dela mesmo [16'31'" E: Uhum] Então é:: sardinha que é uma coisa que nem faz muito parte da alimentação brasileira mas eles trouxeram isso também comer muito peixe \# de modo é:: hã:: quer dizer revisitar essa memória significa pra mim é voltar pra um momento em que as coisas eram mais digamos mais simples mais sinceras mais é \# menos mediadas pelas questões do raciocínio e mais por coisas de coração né \#

17'02'” E: De coração \# uhum

17'03' J: Parece um estereótipo mas é bem essa mesmo a memória que eu tenho da coisa familiar

17'06” E: Interessante \# e então você tava dizendo que eles eram simples e que talvez nem soubessem escrever imagino então- mas tinha ópera.

17'16' J: Tinha

17'17' E: Tinha alguma outra coisa? Livros jornais alguma coisa ligada à leitura escrita pela casa?

17'21' J: Pela casa em italiano eu não me recordo \# eu me recordo assim já de coisas em português na casa da minha avó como aquele Reader's digest que é o:: eu não me lembro agora o nome disso em- em português hã::

17'34' E: É mas eu entendi

17'35' J: é:: e:: e alguma outra:: coisa que minha avó tinha que eu me lembro que eram cartas mas eu nunca cheguei [17'47' E: A ler] a ler nem a perguntar porque eram coisas dela e ela tinha- ela devia ter uma correspondência com alguém não sei se na Itália ou se em alguma outra família mas a impressão que eu tenho é de que 
não é de que era uma família realmente muit::o fechada muito- só entre eles e viviam um pouco assim isolados de tudo com o mínimo para poder subexistir numa cidade como Ribeirão Preto naquela época

18'16' E: Talvez essa coisa que você contou que o seu bisavô poderia ter tido uma outra mulher [18'21' J: Uma outra mulher] na Itália fez com que eles se separassem [18'13' J: Pode ser pode- pode muito bem ser] mais mais fortemente da da Itália \# 18'27' J: É \# quando eu quis levantar toda a história eu tropecei nessa- nesse preconceito nessa- num é nem preconceito é um constrangimento

18'37' E: É um acontecimento que não pode ser contado não pode ser conhecido 18'40' J: Isso \# o lado digamos rui::m da coisa né porque de resto me parecia ser uma família entre eles muito unida né \# tanto que essa minha tia C. ela cuidou de todos os irmãos que ficaram doentes e ela foi praticamente a última a morrer depois de enterrar todos os outros

19'01' E: Interessante

19'02" J: Tem histórias muito tristes aí no meio ela mesma tinh- tava com o enxoval pronto pra casar e o noivo morreu duas semanas antes do casamento

19'11' E: Puxa que tristeza

19'12' J: Então é:: hã:: \#

19'15' E: Tem também umas coisas de azar não só de escolhas não casar \#

19'17' J: Eu não acho que foi uma família feliz \#

19'20'" E: Uhum

19'21" J: Eu acho que foi uma família que é:: se constituiu num mundo muito diferente do mundo deles \# e por isso mesmo foi uma família que se isolou de um contato maior né \# os contatos que tinham também tinham alguma coisa de italiano como por exemplo trabalhar nas indústrias Matarazzo né \# mas quando minha avó por exemplo se viu sozinha ela- ela como viúva não teve condição de manter uma vida sozinha só com filho \# ela teve que voltar pra casa do pai que é meu bisavô e teve que viver de novo como se fosse uma filha solteira com filho sob as ordens dele isso ela sempre disse- que uma vez ela me falou que ela cortou o cabelo tinha um cabelo muito longo cortou o cabelo um pouco mais curto que ele ficou bravíssimo com ela deu um murro na mesa cortou o pulso tiveram que levá-lo ao médico enfim ele era- parecia ser uma pessoa muito austera \#

20'22' E: Uhum então quando ela voltou voltou nessa casa onde moravam todos os outros irmãos? 
20'27' J: Todos os outros irmãos \# ela continuou morando- tanto que meu pai foi criado pelos tios porque aí ela trabalhava fora pra ajudar na família- isso- por isso que eu acho que devia ser uma família muito pobre porque:: mesmo a filha viú::va com uma criança e eram poucas mulheres só três essa era doente e essa ajudava no serviço da casa ela teve que trabalhar fora pra ajudar com algum dinheiro e hã:: portanto meu pai filho dela foi criado pelos tios \#

21'01' E: Hum entendi \# então e- só uma última coisa que eu acho que eu já perguntei de alguma maneira mas só pra confirmar \# então é:: você não- não tinha muitas outras famílias italianas não famílias italianas que eles frequentassem mas tinha italianos em Ribeirão Preto?

21'18' J: Tinha outros italianos em Ribeirão Preto mas não que eles frequentassem isso com toda a certeza \# porque a grande família italiana da cidade era uma família muito rica que era a família Matarazzo né \# eles tinham um haras que existe até hoje tinha a indústria têxtil etc \# então tinha o- os italianos em Ribeirão Preto desses dois lados de um lado muito forte poderoso e de outro lado uma leva de imigrantes que vieram de lugares muitos simples \# com hábitos inclusive que causavam estranheza assim como \# é:: \# enfim questões ligadas a a \# comportamento questões ligadas a ir ao banheiro de porta abe::rta e outras coisas que por exemplo o lado francês e:: \#

22'12'" E: E alemão \#

22'13' J: E alemão minha família estranhava muitíssimo \#

22'17" E: Uhum \# mas na família tinha relações essas partes da família alemã francesa e a dela \#

22'22' J: Com a família alemã não a família- a parte alemã da família da minha mãe era sempre muito reservada sempre foi muito reservada e austera e:: a parte francesa acabou muito cedo porque meu avô morreu com- meu bisavô morreu com cinquenta e quatro anos e meu avô francês que se chamava Jorge (não entendi) ele:: viveu mais tempo mas ele era um homem reservadíssimo também chamado guarda-livros de uma fazenda onde hoje é a USP \# e:: tanto que tem uma foto bem em frente ao museu do café com Schmidt meu avô tá ao lado dele [22'58' E: Ah que legal] que ele era guarda-livros da fazenda \# e as relações entre eles é:: eu \# eu não posso te dizer com toda certeza mas eu poderia talvez afirmar que não que não havia um intercâmbio assim é \# muito:: cordial é \# intercâmbio quase nenhum na verdade porque eu acho que é- embora tivessem vindo pra uma mesma finalidade quer dizer fundar uma 
existência nova num outro país eles traziam uma carga cultural ba::stante diferente né \#

23'35' E: Então não tinha festas de família com todo mundo?

23'38' J: Não \# não

23'38' E: Não?

23'39' J: Não \# mesmo mesmo no começo quando minha mãe era casada com meu pai muitos deles eram vivos eu não me lembro de <nenhuma $>$ festa reunindo toda a família italiana eu me lembro dos almoços na casa da minha avó só \# mas aí era ela o filhos e os netos e mais nada né \#

23'58' E: Interessante \# é eu acho que é isso \# se você tem mais alguma:: coisa que você acha que poderia ser interessante contar \#

24'06' J: Eu tenho todos os discos que eram da minha avó (Risos)

24'08' E: Ah legal \# legal

24'10'” J: Que eu guardei e \#

24'12' E: Isso é uma coisa bem interessante porque parece quase em contradição com-

24'15' J: Uma contradição parece

24'17' E: Com tudo que você conta né família simples os hábitos simples e ao mesmo tempo ouve ópera

24'22' J: E ao mesmo tempo- é ouve ópera e canções napolitanas e:: \# cantadas assim pelos grandes cantores daquela época do final do dezenove discos bem grossos rotações setenta e oito \# eu guardo porque eu cultivo um pouco essas essas coisas né::

24'38' E: Claro isso é muito lindo é muito bonito \# e é interessante é:: evidentemente uma coisa específica para- por música porque né::

24'45”' J: Por música \# é

24'47' E: é essa que era a característica \#

24'49' J: É \# por música \# isso

24'51'" E: Muito bonito \# então eu acho que é isso

24'54'” J: Muito obrigado

24'54' E: Muito obrigada

24'55' J: E eu fico feliz de poder registrar no projeto de vocês essa passagem da família que- se não teria passado desapercebida 
25'04"' E: Aham muito obrigada 


\section{APÊNDICE F - Transcrição da entrevista 06}

E: Bom, muito bem, então, vamos começar a entrevista com o professor J. L. F., e vamos, hã, logo começar com as nossas perguntas. A primeira delas é, o que você sabe de como a sua família veio ao Brasil.

20" J: Bom, é, minha família veio pro Brasil no final do século XIX, e, na verdade, os dois avós do lado do meu pai, o pai do meu pai e a mãe do meu pai são italianos e vieram do Vêneto, é, de uma cidadezinha que eu já visitei que se chama Zimella

E:Zimella? Com z?

J: É, Z

E:Aham

51" J: É, e, é, do lado da minha mãe, eu tenho então, o pai da mãe dela era, portanto meu bisavô, veio do norte da Itália, do Friuli, e, é, e do, e do, e meu avô, pai da minha mãe, aí também era italiano e veio dessa mesma região.

E:Friuli

01'18' J: Agora, é, por que que eles vieram? Bom, quando eu visitei Zimella eu fiquei muito impressionado porque é um lugar, uma, uma aldeia muito pequenininha, hoje muito bonitinha, tem uma igreja com uma gruta de Nossa Senhora de Lourdes no fundo etc e tal, mas eu fiquei olhando aquilo imaginando como devia ser no final do século XIX. Todos eles eram agricultores

E:Sim. Essa cidade fica perto de Treviso?

J: Fica perto da cidade de, da cidade de Romeu e Julieta.

E:Verona.

01'57' J: Verona, fica pertinho de Verona

E:Uhum.

J: Fica uns oito, dez quilômetros de Verona.

E:Certo

J: E, é, e todos eram agricultores e vieram ao Brasil quando houve um incentivo pra imigração europeia no Brasil, e eles vieram pra ser agricultores também/.

E:Uhum

02'23" J: Eles vieram porque as condições de vida na Itália eram muito difíceis pra eles. Eles tavam numa situação de pobreza muito e por isso resolveram fazer a América.

E:Uhum. Mas eles falavam disso? 


\section{J: É}

E:Alguém da família falava?

02'41" J: Falavam. Nós sabíamos dessa história, mas diria que não era um assunto muito recorrente. Havia uma coisa de que eu me lembro, é, eu, minha família era muito católica

E:Uhum

02'54'J: E, é, com muita frequência se rezava o terço em família. E o nonno, pai do meu pai, é, rezava uma, pra São Sebastião, São Roque e São não sei quem, que não me lembro o outro, que nos livre da peste, da fome e da güerra, como ele dizia. Bom, e eu imagino que isso, como isso não é da experiência brasileira, de ninguém, nem a peste, nem a fome e nem a guerra, eu imagino que deveria ser a experiência deles na Itália, e embora não se falasse disso, é, com frequência, não se contasse histórias da Itália, porque, a verdade é que meu avô muito pequeninho da Itália, ele tinha 6 anos de idade, é esse o meu avô com quem eu convivi mais. A minha avó, mãe do meu pai, eu não conheci, a nonna, ela teve um AVC e ficou durante muitos anos paralítica e, é, e daí eles, é, ela tinha morrido antes de minha mãe se casar com meu pai. Portanto eu não a conheci. E o nonno que eu conheci, que é o nonno L., que é o pai do meu pai, esse embora não falasse nisso, essa experiência da Itália, pra mim tava presente em orações que se faziam, etc. e isso era muito recorrente, né.

04'24” E:Uhum. Entendi. Então, ah. Mas se falavam outras histórias sobre a Itália, talvez em casa, além dessa? Assim, essa não era, não era narrativizada, não era falada, mas outras histórias?

J: Olha, na verdade se falava pouco da Itália. Se falava muito da saga que eles viveram no Brasil

E:Uhum.

04'45' J: Porque eles vieram, é, pro Brasil pra ser agricultores. E, então a história deles no Brasil, isso era contado, contado com muito orgulho. É, de todo o trabalho que eles, porque eles trabalharam demais, demais, demais. $\mathrm{E}$ então isso era sim contado com muito orgulho.

05'08' E:Uhum. E eles foram pra que cidade quando chegaram?

J: Bom, quando eles chegaram, eles chegaram pelo Rio de Janeiro e foram pruma cidade de Minas, do sul de Minas, que se chama Lavras.

E:Uhum. 
05'19' J: Eles foram, é, trabalhar na agricultura, mas logo depois eles vie-, é, lá nasceu minha única, irmã do nonno, que, que nasceu no Brasil, que era a tia F.. Essa nasceu no Brasil. E ficou morando nessa cidade, em Lavras, é, é, a família veio, então, pra região de Ribeirão Preto.

E:Sim.

J: Pra trabalhar em cafezais

E:Uhum

J: Aí, em mil novecentos e, por volta de 1905 a 1915, é, começou a abertura da estrada de ferro noroeste do Brasil. Porque é preciso lembrar que no final do século XIX, o estado de São Paulo inteiro era uma mata.

E:Uhum.

06'17' J: É, não muito distante do final do século XIX, a cidade mais ao oeste do estado de São Paulo era Botucatu, que hoje é pertinho de São Paulo. Bom, depois foi fundado Bauru, e se resolveu abrir uma estrada de ferro que fosse, que ligasse, hã, Mato Grosso aos estados que, é, porque, os estados, é, mais próximos do litoral. Porque vir de Mato Grosso naquela época era pelo, por rio, e ia pelo rio da Prata, etc. e depois subia, é, pro, pro sul do Brasil, pra capital, que era o Rio de Janeiro. Bom, e, e a abertura dessa estrada de ferro foi uma coisa muito interessante porque houve um projeto de colonização muito amplo, e nesse projeto de colonização, o que que se fazia? Hã, a cada xis quilômetros, é, havia uma estação de trem, e nessa estação de trem se fundava uma cidade.

E:Uhum.

07'25' J: E começou-se então a vender terras por um preço muito barato. E eles tinham economizado, economizado trabalhando em Ribeirão Preto pra comprar terras. O sonho deles era ser proprietário de terras. Era ser, continuar na agricultura, mas como proprietário de terras. E então eles compraram terras em Birigui.

E:Uhum.

07'48' J: É, onde havia, isso foi, se não me falha a memória, em 1911 ou 1912, por aí. Eles, é, compraram terras em Birigui, e vieram pra Birigui onde eles derrubaram a mata e plantaram café. E foram cafeicultores, é, durante um tempo, é, longo. Mais adiante, eles abriram uma pensão, hum, que era como se chamava esses hotéis modestos, na cidade de Birigui.

E:Uhum.

J: E na frente dessa pensão abriram um armazém de secos e molhados. 
E:Ah, lógico, eu tava esperando o armazém.

J: É, um armazém de secos e molhados, que era um armazém enorme num, num determinado tempo.

E:Uhum.

08'38' J: E aí eles continuaram mantendo as terras, mas já morando na cidade, é, foram, foram donos dessa pensão e desse armazém. Com o tempo o armazém teve um desenvolvimento muito grande, a pensão foi fechada, e daí eles continuaram com esse armazém até, hum, um tempo em que a maneira de fazer negócios obrigou a fechar esse armazém, porque, na verdade eles forneciam, é, o que se chamavam, os mantimentos pros agricultores durante $o$ ano inteiro pra receber depois da colheita do café.

E:Sei.

J: E isso funcionou muito bem enquanto não havia inflação no Brasil. Quando a inflação começou a acelerar, era uma perda enorme, e com o tempo acabaram falindo, né.

09'29' E:Entendi. E alguém falava italiano?

J: O Nonno falava italiano, e falava italiano com os filhos. É, na verdade.

E:O nonno L.?

09'39" J: O nonno L., que foi o que eu conheci melhor.

E:Sim.

J: Porque o outro, é, o, o, o pai da minha mãe já não falava italiano porque a mãe da minha mãe não era italiana.

E:Sim,

09'54" J: E então eles já não falavam italiano. Mas o nonno L. sim, falava italiano, um dialeto Vêneto, e, e, e eles conversavam entre eles em italiano, principalmente quando era pras crianças não saberem do que se falava, aí eles falavam italiano, era uma língua secreta. Mas eu tenho impressão, hoje me lembrando de coisas que o nonno dizia, e, eu tenho impressão que ele nunca aprendeu o português direito, e, é, e esqueceu o italiano, então o que ele falava era uma interlíngua. É, é a impressão que eu tenho.

E:Uhum

10'35" J: Né. Agora, nós nã, não aprendemos o italiano, a, nós aprendemos a entender $\mathrm{o}$ italiano. Mas minha mãe se opunha terminantemente a que a gente falasse italiano, porque na época os italianos eram ridicularizados pelo sotaque. Um sotaque, 
é, que a gente encontra ainda, por exemplo, no Rio Grande do Sul, e ela não queria que a gente pegasse sotaque, como se isso, se isso fosse possível etc., mas, enfim, é, nós aprendemos no final das contas a entender o italiano mas não a falar o italiano. 11'17' E: Uhum. Então, é, assim, a, a última pergunta é sobre como você acha o que é, o que foi, ser italiano no Brasil e como você acha que os brasileiros veem os italianos, ou viam os italianos, talvez, na época que seus avós chegaram.

11'32' J: Acho que viam. Bom, é, nós sabemos que a, a imigração europeia foi incentivada no final do século XIX dentro de um projeto político de branqueamento do Brasil. Isso, é, principalmente depois da abolição da escravatura. A abolição da escravatura significou, é, na verdade, é, a abolição da escravatura de um lado você já, os, os, os escravos passaram a ser livres, no entanto não houve nenhuma política de integração desses escravos, de apoio desses escravos, e de transformar esses escravos em trabalhadores livres. O que houve na verdade foi um projeto de trazer os imigrantes pro Brasil. Bom, é, e aí, de um certo ponto de vista, a vida dos imigrantes foi, é, digamos facilitada pelo fato de que havia, é, possibilidades, seja de doação de terras, seja de compra de terra abaixo do preço etc. e tal. No entanto, é, foi muito difícil ser imigrante no Brasil, porque os imigrantes de um lado eram vistos pelos fazendeiros onde eles, é, foram traba-, nas fazendas onde eles foram trabalhar, os proprietários das fazendas onde eles foram trabalhar, como se eles fossem escravos. Aqueles, aqueles, é, fazendeiros tavam acostumadas a lidar com escravos e tinham muita dificuldade de, é, lidar como trabalho livre, é, com o trabalho assalariado. E então foi, as condições de vida foram muito duras, e é por isso que eu digo que eles, o Nonno contava sempre com muito orgulho tudo o que ele teve que, é, superar no Brasil. Bom, depois, mais adiante, é, os italianos eram vistos com certo desdém, com certo preconceito, principalmente, é, numa cidade, nas cidades maiores onde havia uma classe de proprietários, é, que detinha todos os controles etc. É, depois, e, veja, por exemplo, então se ridicularizava a maneira como os italianos falavam, é, português, é, e, e, então era difícil. Depois a vida se tornou ainda mais difícil no período da segunda guerra. Nós não podemos esquecer que as grandes comunidades imigrantes, principalmente naquela época, as que existiam, os italianos e os alemães tinham uma imprensa própria, uma imprensa escrita em italiano e em alemão.

E:Uhum.

14'39' J: Tinham escolas que ensinavam em italiano e alemão. Tinham cultos religiosos, seja os católicos, seja os protestantes, que eram feito em alemão e italiano. 
Logo que o Brasil entra na guerra depois da, depois da, entra na, na, na, do lado dos aliados na segunda guerra, Getúlio começa uma série de discursos sobre a necessidade, é, de reforçar os laços da nacionalidade, e por isso ele proibiu então todo o uso, é, de, proibiu a imprensa em língua estrangeira, proibiu, é, os cultos em língua estrangeira, proibiu as escolas em língua estrangeira, é, todos os diretores de escola tinham que ser brasileiros etc. Olha, isso se poderia dizer que foi uma coisa oficial, mas é interessante como nesses momentos, a, a, o que é oficial se espalha na direção das relações cotidianas, então, muitos italianos eram agredidos por falar italiano na rua e muitos eram ridicularizados por falar italiano na rua, e foi, é, e foram essas experiências que levaram minha mãe a não querer que a gente soubesse italiano. Então era muito difícil. No entanto, é preciso que se diga que eles tiveram uma força extraordinária. Bom, é, na verdade o sonho deles era sempre, é, ganhar dinheiro na América e voltar pra Itália.

E:Uhum.

16'25' J: Eles nunca voltaram pra Itália, é, na minha família foi a minha geração que foi conhecer a Itália. Nem a geração do meu pai e da minha mãe foi conhecer a Itália. Fomos nós a primeira geração a conhecer a Itália. É, um, é, meus irmãos, meus primos, eu etc. que fomos conhecer a Itália.

E:Uhum.

J: É, mas os italianos foram, é, a medida em que foram enriquecendo, foram ocupando lugares na sociedade, e aí os, os, os preconceitos foram desaparecendo.

E:Uhum

17'08' J: E os italianos se integraram de maneira perfeita, eu acho, no Brasil. Hoje quando me dizem, por exemplo, se eu tenho vontade de requerer a cidadania italiana, eu digo que não tenho nenhuma porque há nenhuma razão pra eu requerer a cidadania italiana, dado que eu não sou italiano, sou brasileiro.

E:Uhum.

17'27' J: Eu tenho muito orgulho da origem italiana que eu tenho, mas não sou italiano, sou brasileiro.

17'35' E:Uhum. E cê lembra, por acaso, eles ficavam juntos? Entre italianos?

17'39' J: Ficavam muito juntos. É, quando, quando eu era criança eles, por exemplo, é, o lugar onde meus avós tinham um sítio, não vou dizer que era uma fazenda, não era pequeno, mas também era um sítio, né. É, era um bairro que se chamava córrego do almoço, ou na linguagem deles, corgo do almoço. 


\section{E:(Risos)}

J: Né, é, e, e, no córrego do almo-, é, é, é uma coisa interessante porque foram criando esse, é, que se chamavam patrimônios.

\section{E:Uhum}

18'20' J: Eles foram criando esses patrimônios, é, ao re-, é, dentro do, da área que é o município de Birigui. E esses patrimônios, porque era longe vir pra Birigui e não havia carros eles precisavam vir a cavalo ou de carro de boi, então era difícil vir a Birigui, e então eles fundaram esses patrimônios onde existia, sempre, uma igreja, um salão paroquial onde eles faziam festa. E aí eles se reuniam todos os finais de semana pra missa, pra, a, nem todos os domingos havia missa porque os padres se revezavam pelos patrimônios etc., mas quando havia missa eles se reuniam pra missa, se reuniam pra um almoço coletivo.

\section{E:Uhum.}

J: É, pra cantar, pra jogar boccia.

E:Uhum

19'22' J: E, e então, é, essas coisas, é, sempre existiram. É interessante porque eu nunca mais voltei a esses patrimônios pra saber o que que eles viraram, Birigui.

E:Uhum.

J: Se ainda existe as igrejas que havia. Mas era uns 12, 14 desses patrimônios que havia dentro da cidade de Birigui.

E:Uhum.

19'44" J: Então eles se reuniam muito. E aí eles conversavam no dialeto vêneto e tal.

E:E faziam comida italiana?

J: E faziam comida italiana.

E:Uhum.

J: Claro. Pasta e.

E:Coisas variadas.

J: É

E:Tudo italiano. E assim, você acha que tem algum traço, assim, da italianidade que se sentia ali, o fato de serem trabalhadores, mais alguma outra coisa que, que definia o ser italiano. Só

20'12' J: Sabe. Eu não sei direito, hã, se havia um traço de italianidade. Porque o fato deles serem extremamente trabalhadores, e todos eram, eu não atribuo isso a um traço de italianidade, eu atribuo isso ao fato deles serem imigrantes. O imigrante vai 
pra um determinado lugar por condições de vida muito difíceis, e ele sabe que ele tem que trabalhar, é, pra sair daquela situação que o levou à imigração etc., então eu não vejo isso como um traço de italianidade, é, também não vejo, assim, uma disciplina que eles transmitiram aos filhos, disciplina do trabalho etc., porque isso também eu vi nas comunidades alemãs, nas comunidades, é, nas comunidades, é, polonesas, é, ucranianas, é, e, e, que eu visitei. É, japonesas. Então, e, eu atribuo isso a um traço, é, de ser imigrante, não de ser italiano. Mas de qualquer forma eu quero dizer pra você uma coisa de que eu me lembrei agora.

E: Hum.

21'29' J: Eles se achavam diferentes dos brasileiros.

E:Ótimo, importante.

J: Brasiliano

E:Uhum.

J: Pro Nonno, L., era quase um xingamento.

E: Opa.

J: Chamar alguém de brasiliano.

E: ohohooo.

J: Certo

E:Certo.

J: Quer dizer, ele, eu diria quase um xingamento porque na verdade ele não tratava ninguém de brasiliano. Isso era dito na, na intimidade. Questo brasiliano. E isso era um tom meio depreciativo, né.

E:Aham, pejorativo. E em casa eles eram autoritários?

22'09' J: Eram. Eram porque eles achavam que tinha que ter uma disciplina e, a, digamos assim, nós fomos criados, eu num, num, nunca achei que eles fossem autoritários, mas havia uma disciplina muito rigorosa que levava um respeito muito grande aos pais, aos avós, aos tios etc., por exemplo, em casa era habitual, bom, ninguém dizia você pro pai, pra mãe, pro avô. É, acredito que em lugar nenhum do mundo nessa época se tratava com a familiaridade como, é, por exemplo, uma sobrinha-neta que eu tenho trata os pais, né.

E:Aham.

J: Bom, mas, é, e havia o hábito de tomar a benção, de todas essas coisas

E:(inaudível). 
23'02' J: Como era. Eu não diria que eles foram mais autoritários do que, do que, do que eram os pais na época. Mas era uma coisa muito, nós sas, nós sabíamos que tinha que obedecer. Mas, por exemplo, meu pai e minha mã-, minha mãe até que um pouco mais, é, dava umas palmadas na gente. Meu pai, eu me lembro de só uma vez ter levado umas palmadas dele, porque se meu pai fizesse isso era por causa de uma coisa muito séria. Eu nem me lembro mais porque que era, mas eu me lembro que era uma coisa. Então eles não foram, não foi assim, não era gente que castigava fisicamente.

E:(inaudível).

J: Mas havia um, uma, um quadro de respeito, de obediência aos pais e tal.

E:Uhum.

J: Que era o comum

E:É

J: em todas as famílias da época.

23'56" E:Provavelmente não diferente de uma família de outra origem né.

J: É

E:Porque era algo assim pra todo mundo. Bom, eu acho, tem mais alguma coisa que você tá lembrando, não?

J: Não.

E:Então tá bom.

J: Cê viu que não ajudei.

24'08' E:Não! Ajudou muito, ajudou bastante. Então muito obrigada, muito obrigada ao professor F.. E podemos... 


\section{APÊNDICE G - Transcrição da entrevista 07}

03" E: Então muito bem vamos começar a entrevista com o professor M. /A. boa tarde professor\#

08"' M: Boa tarde

09" E: e:: vamos começar com uma pergunta ou prefere::

14" M: pode ser por favor\#

15" E: Então olha a primeira pergunta é o que você sabe de como sua família veio para o Brasil?

24" M: olha a família veio no final do século dezenove tanto da parte- os meus avós maternos eu tenho descendência italiana pela minha mãe o que\# são do Veneto\#

44" E: Sabe qual é a cidade exata?

45"'M: Sim o meu avô a família do meu avô é da cidade:: não sei se é cidade paese \# é de Fiesso Umbertiano não fica longe de Veneza fica em Rovigo e é de lá\# eles tinham uma propriedade rural mas acho que não havia lugar para todo mundo

01'08' E: Sim\#

01'10" M: Então\# não havia como\# um momento de exportação de pobreza da Itália né? Eu fico sempre pensando assim vendo esse esse pessoal da Síria não era tão dramático mas havia uma tragédia social muito séria porque ninguém muda de país dessa forma tão radical por nada é para ganhar dinheiro ou para sobreviver porque não tem condições no seu país então\#

01'35' E: O avô era da província de Rovigo?

01'37' M: O avô sim era da província de Rovigo e a minha avó eu esqueci mas era de de- lugar perto também e\#

01'44'" E: Eles se conheceram aqui?

01'46" M: Eles se conheceram aqui no interior de São Paulo a:: os italianos vinham para cá e depois eram removidos para as fazendas de café daquela região e era uma situação muito muitas vezes- nada fácil né? Porque (não entendi) era muito difícil então eles foram para as colônias trabalhar e a vida assim- era muito difícil aquelas histórias aquelas piadas que se fala da da polenta e a sardinha que era para a família inteira você conhece né?

02'30' E: sim sim sim\#

02'31' M: Isso era muito comum essas piadas ou então o menininho italiano que ia para a escola e a professora perguntava o que vocês comeram hoje e ele falava 
polenta aí ele ia pra casa e os pais perguntavam o que ele fez na escola e ele falava que a professora perguntou o que a gente comeu em casa e o que você disse? Polenta não mas você tem que falar que comeu arroz aí ia pra escola e a professora perguntava $<0$ que você comeu hoje? > Polenta- arroz quantos pratos? três fetas (risos)

03'09' E: Mas essa história quem contava?

03'12' M: Se contava assim\# entre nós mesmos a pessoa ri de si mesmo uma coisa engraçada na família da da minha avó ela (não entendi) \# acho meio tocante isso sabe? Eles não sabiam falar nada falavam dialeto veneto e aí eles precisavam comprar sabão e chegaram numa venda num armazém e pediram isso aqui aí eles passavam na roupa e juntava mosca ao invés de limpar ficava juntando mosca quando foram ver era rapadura essas coisas são folclóricas né?

03'56' E: Mas acontecia \#

03'57' M: Mas acontecia \#é muito engraçado e:: \#

04'00' E: Deixa eu ver aqui

04'02'" M: Eles vieram de navio foram para o Brás depois foram triados e eles foram levados pra lá

04'08' E: Mas vieram diretamente para São Paulo?

04'10"' M: Vieram pra São Paulo Santos estação do Brás e depois foram pra pra::\#

04'16" E: Essa cidade

04'17' M: Essa cidade

04'18'" E: Que é Pinhal?

04'20' M: Pinhal Espírito Santo do Pinhal era Pinhal depois Espírito Santo do Pinhal (não entendi) mas é Pinhal fica na Mantiqueira e:: então\#

04'27' E: O que eles faz- fizeram?

04'28' M: Eram lavradores foram trabalhar na roça em fazendas de café e aí meu avô \# veio com o irmão dele \# e o irmão foi para o Paraná foi para o norte do Paraná e era comum essa passagem para o Paraná e:: \#

04'49" E: Sim sim chegaram juntos e depois ficaram separados?

04'52'" M: Sim chegaram juntos isso olha tanto que eu nunca mais vi a- \# o contato com a minha família da Itália \# aí é mais complicado porque eu tenho um tio que recebia cartas e meu avô recebia um dinheiro da Itália uma renda daquela terra deles lá e eles pagavam tudo sabe? E depois com o Getúlio Vargas acabou tudo então e meu tio recebia cartas trocavam cartas mas também perderam o contato e:: \# 
05'20' E: Cartas com a família que tinha ficado na Itália?

05'22"' M: sim sim sim \#

05'23' E: Irmãos? outros irmãos?

05'26' M: Não porque não tinham mais irmãos os tios primos todo mundo

05'28' E: O restante \#

05'29" M: É toda a família aí o meu avô se tornou administrador da fazenda e tal e ele conheceu minha avô é muito engraçado porque eles falavam o italiano \#

05'50' E: o dialeto veneto \#

05'51''M: O talian \# mas entendiam o italiano \# tinha o circolo italiano também Dante Alighieri

06'05' E: na cidade?

06'06" M: na cidade meu avô fazia parte e tal \#mas com as coisas do Getúlio e tudo e eu sofri um pouco com essa onda nacionalista e não sei o quê e nós tinhamos muita conversa com meus amiguinhos

06'25' E: Se contavam histórias sobre a Itália?

06'27' M: contava \#sobre a Itália:: contava-se

06'29" E: Quantos anos tinham o seu \#

06'31'" M: O meu avô? O meu avô veja \#

06'34" E: quantos anos tinham quando vieram pra cá? Eles eram meninos?

06'36" M: Não eles \# era menino o irmão dele era mais velho a minha avó e os tios dele conduziram os irmãos da minha avó todos e \#

06'44' E: Quer dizer eles tinham ido pra escola na Itália antes de vir pra cá? Ou (não entendi)

06'47' M: O meu avô deixa o meu avô \# eu acho que não os irmãos dele sim ele tava começando e tal porque aqui ele já \# hã:: ele foi alfabetizado no Brasil e tal mas ele falava o italiano e tal não sei que (não entendi - 06:59) aí foi a primeira língua da minha mãe \#

07'03' E: Certo

07'04' M: Aí um- uma coisa \# (não entendi) esse papo de identidade\# (não entendi) \# Hã:: minha meu pai por exemplo ficou órfão muito cedo hã:: doze treze anos \# e ele foi morar com a família italiana mas (não entendi) na Itália então e o patriarca (não entendi) o patriarca era calabrês e o meu pai começou a entender (não entendi) mas era muito engraçado aprendeu \#

07'35' E: Eu não entendi esse calabrês \# era? 
07'38' M: Esse calabrês era um senhor que morava com a família e a família era calabesa\#

07'39' E: ah tá

07'41' M: e:: meu pai foi morar com eles e trabalhando e tal\#

07'44" E: ah entendi

07'45' M: e vendo esse esse esse patriarca que virou uma espécie de pai adotivo do meu pai

07'49'" E: Certo

07'50" M: Que é uma pessoa que tinha (não entendi) ética e tudo isso e ensinava e tal faz isso e tal é muito legal

07'57' E: Então é um italiano adotivo? Seu pai? (risos)

07'59" M: é italiano adotivo adotivo mas veja só que coisa engraçada é adotivo ele hã:: ele:: essa de você \# de:: sabe \# você vive num universo ali e você vai acabar \# você começa entendendo e começa a falar e tal num sei que e aprende a falar tudo que é palavrão primeiro lógico né e então uma \# uma esse universo assim agora se havia alguma \# bem \# havia uma pressão assim \# provavelmente por causa do Getúlio Vargas \# meu pai falava muito do Fanfulla e aquele Fanfulla \# lia-se o Fanfulla naquela \# um- e o meu pai ficou conhecido como B. que é o nome da família B. \# todo mundo era certo de que ele era italiano também B. B. (não entendi) tinha cara de italiano (risos) mas \# o:: o:: B. e tal não sei que lá \# olha \# é engraçado\# e aí o hã:: bom \# ele era assim mas então nós éramos eu e:: era os meninos e conversávamos o que você vai ser? Eu vou ser italiano \# (não entendi) \#

09'06" E: Quem dizia isso?

09'07' M: Os amigos \#

09'08' E: Os amigos? Uhum \#

09'09' M: Eu não eu vou ser brasileiro \# e tal não sei o quê \#

09'10' E: Ah tinha isso?

09'11' M: Isso mas isso assim com dez anos de idade \#

09'14"' E: Mas como se entendia isso? Eu vou ser italiano \#

09'18' M: Eu vou assumir a nacionalidade italiana \#

09'19' E: Ah sim entendi ah que interessante isso

09'22'” M: E eu achava não eu vou ser brasileiro e vou ser brasileiro e não sei que lá e tal

09'27' E: ah que legal \# 
09'28' M: E:: eu tinha aquela onda assim \# não sabia se:: ah a sociedade Dante Alighieri foi fechada

09'33'" E: ah sim \#

09'34" M: aquela ideia do (não entendi) Getúlio Vargas \# aquelas coisas todas aquilo era uma coisa muito hã:: e evidentemente eu comecei a não gostar do Getúlio Vargas a partir daí. (risos)

(não entendi) a sociedade brasileira (não entendi) muito vago mas eu já não gostava \# agora o Mussolini era um ídolo dos italianos você sabe disso né? Meu pai mesmo gostava dele

09'55' E: Minha avó também

09'56" M: Gostava dele né? Mas o Mussolini e num sei o que e tal e eu falava puta que la \# mas o Mussolini? Ma vá \# (risos). E aí e aí o::

10'05' E: Então a Itália entrava um pouco com essas histórias? Se falava \# ?

10'07' M: Entrava entrava com essas histórias entrava com essa presença mesmo sabe? Também os costumes os costumes de alimentação que era:: rigorosamente italiana né? Não tinha jeito imagina que você tem uma mãe italiana e não tem como você sair disso o que eu acho ótimo não tem nada que pelo contrário

10'23"' E: E o Mussolini vinha assim \# como vocês sabiam? Através dos jornais?

10'27' M: Vinha \# através dos jornais não através de- do meu pai dos- das pessoas mais velhas que falavam\# pessoal admirava o Mussolini.

10'29" E: Sim mas digo como eles se informavam? Sobre o que estava acontecendo na Itália \#

10'31" M: Ah sim o Fanfulla o jornal e tal mas minha mãe contou como é que ele morreu (não entendi) \# deu um tiro nele morto e pendurado e tal e não sei que lá (não entendi) isso já me passou outra coisa percebe? Aí eu falei não esse cara não é legal não \# não pode ser legal. (Risos)

10'48' E: Então circulavam os jornais?

10'50' M: Sim circulavam o Fanfulla chegava lá naquele tempo

10'53" E: Mas na sociedade Dante Alighieri? Na sua casa? Onde é que se lia jornal?

10'55' M: Não \# eles diziam \# acho que na sociedade Dante Alighieri lá em casa não (não entendi) que já era tô falando dos anos trinta né?

11'04'" E: Sim claro

11'06' M: Então eu não sei então (não entendi) \# ainda tinha rádio (não entendi) eles sintonizavam 
11'16" E: E se sintonizavam então à rádio italiana? Então é isso?

11'19" M: Claro as pessoas sintonizavam tranquilo \# lá em casa eu tinha um rádio desses nos anos cinquenta e eu eu sempre tive paixão pelo castelhano por exemplo então eu fazia o seguinte de manhã eu sintonizava rádio uma rádio da Espanha \# a tarde eu sintonizava o:: seis horas da tarde eu sintonizava a rádio pequi falando castelhano e às- antes de dormir mais tarde \# eu sintonizava é:: dez horas \# eu sintonizava a rádio Buenos Aires ouvia todos os tipos de castelhano \# (não entendi) tanto que quando eu comecei a ler castelhano eu fui direto eu não tive nem coisa e tal \#

11'59'" E: Interessante \#

12'01" M: (Não entendi) e era o tempo da \# logo depois veio o tempo da grande música italiana e do cinema italiano \# que é uma coisa maravilhosa \# assim né:: é uma coisa \# isso foi é:: muito forte (não entendi) \# da música \#

12'12' E: Eu sempre digo que naquela época eles fizeram uma obra de divulgação da- muito boa \# é que \#

12'18' M: Música de qualidade também né?

12'20" E: É que hoje não se faz mais as músicas que eles se lembram hoje são aquelas

12'23" M: É:: você vê que por exemplo (não entendi) pra entender que você tá apaixonado por uma menina é em italiano (não entendi) \# sabe? E não te::m não tem nada pra mim tão romântico quanto aquilo e eu gosto muito e eu me lembro uma vez que eu vi aquela <la casa di... > (não entendi) você se lembra daquilo? Aí eu vi aquilo e aprendi e tal aí cheguei pro meu avô e meu avô era muito fechado e (não entendi) \# porque essa música \# eu vou \# (não entendi) \# é assim la casa di \# ${ }^{* *}$ (Ele canta mas não consigo entender a letra da música)

Che è un desiderio di te..

entã:::o (não entendi) \# aí eu cantei pro meu avô ele olhou pra mim feio e falou assim \# ah isso aí não sei o que e tal claro era um prostíbulo era um puteiro então ele falou não

13'31' E: Não pode falar. (Risos)

13'32'” M: Então não podia mas eu não sabia eu não entendia direito eu tinha:: então eu gostava do- da música e:: das palavras só isso e:: (risos)

13'40" E: O que tinha por trás

13'41" M: Não fazia sentido pra mim (risos) magina eu tinha:: eu era menino e tal \# 
13'46" E: Legal. Se falava italiano então na sua casa?

13'49"' M: Não não se falava falava só:: fiapos de italiano:: porque minha mãe parou de falar depois que cresceu porque não falava mais em casa e não falava mas ela o que acontece é o seguinte o italiano se excluía na linguagem local e digo até hoje \# eu escrevo:: penso palavras que pra mim são em português e não elas são italianas. 14'12"' E: Você falou da carriola.

14'14" M: da carriola isso é só um exemplo só um exemplinho tem um monte de coisa as interjeições sabe? Umas expressões uns palavrões vai que:: sabe? tudo isso assim é uma \#

14'28' E: Os palavrões palavras de comida com certeza

14'31'" M: Comida sim sim \#

14'32'" E: Você falou em italiano

14'34' M: Sim \# são tudo os nomes assim \#

14'36"' E: Mas a carriola é interessante \#

14'38'” M: Eu \# ó:: uma vez eu tava na Itália quando eu tava em Roma foi a primeira vez que eu fui pra lá \# aí eu me encontrei com uma amiga \# por acaso e o marido dela que é italiano e ela brasileira \# aí eu- foi uma cena assim \# interessante \# eu tava com uma mala aí ela caiu no meu pé e eu falei <madosca> (risos) aí ele olhou assim e falou <o que você disse? > eu falei assim \# o italiano falando comigo <o que você disse?> <madosca> ele falou \# <de onde você ouviu essa palavra? onde você aprendeu? >Mas ele fala- ele fala vários dialetos diferentes \# eu não ouço essa palavra:: porque isso lá na minha cidadezinha se falava isso aí mas agora ninguém mais sabe direito o que é lá vamos jantar comigo vamos aí o cara virou um amigão meu por causa de uma palavra madosca mas quer dizer porca madosca porca miséria 15'30' E: Pra não dizer porca madona se diz porca madosca? Exatamente 15'34' M: então é uma coisa que muito \# 15'35' E: Mas veja é interessante

15'38'" M: Mas veja como é que:: eu sempre sentindo aquela coisa assim mas eu num \# mas veja como aquela viagem para Roma foi interessante pra mim \# claro Roma é sempre interessante é uma cidade particularmente interessante \# e isso mexeu comigo de uma forma extremamente positiva \# mas caminhando por Roma andando assim \# hã:: aí eu senti assim uma coisa assim \#puxa vida \#claro (não entendi) isso não tinha nada a ver com Roma mas é parte desse universo aqui né:: aí foi umas \# tem uma \#uma coisa \# senti um certo \# (não entendi) \# isso que me fez mal \# por que 
eu tô sentindo isso? Coisa imbecil \# não tem nada a ver \# (não entendi) \# todo francês vai achar que é Vitor Hugo? Num faz sentido né?

16'37' M: Então eu \# entã::o todo italiano achar que é:: sei lá \# é::

16'43'” E: Galileu Galilei \# (risos)

16'47' M: Ou então \#

16'48' E: Michelangelo (risos)

16'49'” M: (Não entendi)

16'49' M: É claro que não mas \# tem uma cultura que não é brincadeira né? \# Então é uma coisa assim que \#

16'58' E: Então você se sentiu parte daquilo?

17'00'” M: Senti \#

17'01'' E: uhum \#

17'02' M: Mas eu me senti assim de forma assim (não entendi) demais que eu não queria sentir assim \# (não entendi) você entendeu? Foi mais forte do que eu \#

17'10’' M: E entã::o

17'11' E: E então como você acha que era \# você disse que na cidade só tinha italiano \#

17'12' M: (não entendi) italiano \# não tinha outra coisa \#

17'13' E: E como essas pessoas se sentiam? Se sentiam estrangeiros eram bem aceitos?

17'17' M: Não não \# eram brasileiros filhos de tal \# e:: mas havia um certo- havia uma certa- havia um- um (não entendi) uma ênfase italiana que eu disse \# sabiam que eram descendentes de italianos muito bem \#

17'35' M: E:: e havia sim realmente uma- uma mas consciência havia sim \# e outros problemas que haviam os conflitos e tudo isso né?

17'46' E: uhum

17'47' M: (não entendi) você sabe também que é uma beleza isso né? Mas havia também solidariedade (não entendi) \# uma coisa \#

17'52'” E: E bem na época do Getúlio Vargas \# tinha::

17’55' M: Eu só sei de memória \# mas aí é uma coisa \#

17'58' E: te contavam coisas de vergonha ou de se esconder?

18'02' M: Aí é uma coisa que havia certo silêncio \# a minha tia rasgou a certidão de nascimento do meu avô. Depois deu um puta trabalho pra tirar de novo

18'16" E: pra tirar de novo sim \# 
18'17' M: Agora é fácil \#

18'19"' M: Depois você vê que eu descobri que o nome dele não era:: hã:: aquelas bobagens \# ele se chamava J. \# G. \# o filho J. F. F. \# aí eu fui atrás \# ah é tal fui atrás legal \# aí descobriram que aquela pessoa exatamente não se chamava $G$. \# se chamava \# porque uma vez eu perguntei \# esse lance de família \# olha pra você ver como era uma comunicação bacana \# eu perguntei assim \# eu eu que sempre fui muito assim curioso falei assim nonno como é que \# é seu nome em italiano? Em italiano como é que se fala? G. né? Não se fala $\mathrm{S}$. \#

18'58'" E: ah::

18'59" M: Aí- aí quando eu vi as coisas \# ele se chamava S. não era \# S. P. G. aí eu falei- aí que:: aí eu- eu era a única pessoa na família até hoje que sabe que o nome do nonno era S. P.G. \#

19'15' E: Então G.- J. ficou porque era o único que dava para traduzir e \#

19'19'” M: Dava para traduzir e falar do- J. aquelas coisas sabe como é?

19'21' E: A::

19'22'” M: Então pronto \#

19'23"' E: Então era assim então?

19'24' M: Era mais fácil \# S. era um nome meio estranho \# P.ia virar P. \#

19'29" E: Olha que interessante e assim aquela coisa de ser italiano no Brasil mesmo depois \#agora- cê acha que tem algum tipo- como você sente essa coisa de ser italiano \# como são vistos os italianos no Brasil?

19'43"' M: Ah olha::

19'44'" E: naquela época \# hoje \#

19'45" M: Não naquela época havia assim \# um \# certo preconceito com as pessoas italianas você sabe disso \# mas é uma coisa- só que os italianos eles eram tão positivos (risos) havia uns mequetrefes- você sabe- sempre tem é normal \# 19'58' E: Ah sim

19'59" M: Mas a contribuição era:: \# era tão bacana sabe? Um pessoal tão trabalhador (não entendi) sacrificado e o pessoal do Veneto é gente muito séria \# 20'08' E: Uhum

20'09" M: Muito séria mesmo \# e:: e:: a fama entre os próprios membros da comunidade assim por exemplo- o pessoal tinha preconceito com o pessoal calabrenapolitano \#

20'22'” E: Ah é? 
20'23' M: Napolitano calabrês e tal não sei que lá \#

20'25' E: Uhum

20'26" M: Napolitano urbano putz é tudo desgraça- havia essa coisa \#

20'31' E: Mas era \#quais eram os traços que determinavam preconceito?

20'36' M: Os traços assim \# que achavam que napolitano era tudo- era tudo vigarista e tal e num sei o quê:: e:: então era um

20'46" E: Mesmo com o patriarca calabrês?

20'48'” M: E:: mas é assim sabe? (risos) (não entendi) \# mas foi muito legal pro meu pai entã::o ajudou a formar o caráter do meu pai \#

20'57' E: Não é \#

20'59"' M: E aquela coisa italiana você sabe né? Aquela coisa muito certa ele fala e tal \#

21'02'" E: Uhum <ética no trabalho> a palavra

2'03' M: Ética no trabalho isso é uma coisa- isso é fortíssimo palavra ética no trabalho por exemplo uma das coisas que mais me marcou acima de qualquer coisa a pessoa que não trabalhava ficava- pra mim é assim até hoje \# essa cultura do trabalho- isso eu não consigo nem tirar \# porque eu- eu- pra mim o trabalho é uma coisa rigorosa \# não te::m não te::m- eu tenho isso não tem como tirar isso entã::o

21'26" E: Uhum

21'27' M: Até já pensei mas não tem como eu posso até pensar mas eu faço \# não faço o que tô pensando \# entã::o essa- hã:: e até hoje uma coisa assim a pessoa pra mim que não trabalha é uma coisa que realmente que:: que:: me desestrutura numnão- cê não trabalha porque tá rico e tal milionário e tal num sei quê:: também olhando assim já não me bas- já não me piace (risos)

21'48" M: É uma coisa que::

21'50" E: E pode trabalhar e não ganhar dinheiro isso pode?

21'53" M: Olha \# é que é difícil ganhar dinheiro com o trabalho (risos)

21'55' M: Mas vamos lá \# entendeu?

21'57' M: Trabalho sem trabalho não acho legal não \#

21'59"' E: Escuta e essa coisa dos italianos autoritários \#

22'02'" M: é muito autoritários \#

22'04" E: isso se confirma assim na sua memória \#

22'06'" M: se confirma

22'07' E: nas suas \# 
22'08' M: Nossa claro são- é lógico que sim é lógico \# porque eu vi todos os irmãos da minha mãe \# meu pai também é:: isso acabou acabou- por exemplo na hora- isso eu sinto até saudades \#quer saber por exemplo na hora da refeição enquanto meu pai não começasse a comer ninguém comia \#

22'28' E: Uhum sim sim

22'31' M: Sabe? \#

22'32" E: Uhum

22'33"' M: E:: e:: só que eu acho isso bacana (risos). Não que eu pratique isso mas eu acho bacana sabe você \# é um momento de autoridade mas também é um momento de amor \#

22'45' E: Aham ah legal!

22'49'" M: (risos)

22'50' E: Bom muito bem as minhas perguntas acabaram \#

22'52' M: Ah é?

22'53" E: Se você quiser dizer mais alguma coisa \#

22'54" M: Ah eu posso falar essas histórias de vida assim- então eu:: eu:: hã:: \# sempre também namorei as meninas filhas de italiano (não entendi) \# era normal \# 23'09" E: Só tinha né? cê falou que na sua cidade era só o que tinha \# 23'11" M: Sim \#lá na cidade sim \#mas aqui em São Paulo também pois a maioria também é italiana minha mulher também tem a descendência de italiano \# do Veneto também \# mas eles são urbanos de Lucca

23'20'" E: De?

23'21" M: Lucca

23'22' E: Ah então é da Toscana

23'23'" M: da Toscana sim

23'24"' E: Ah tá não do Veneto?

23'25' M: Não do Veneto não do Veneto não desculpa (não entendi)

23'27' E: É da Toscana

23'29”' M: A família dela M. então é uma- assim uma:: não porque se programa isso é porque::

23'39"' E: Acontece

23'40"' M: É acontece e:: uma:: uma:: coisa por exemplo uma vinda e tal nunca- bom se ela lê assim \# vindo lendo \# e:: bastante tempo eu falei assim \# agora vou ter de ler pelo menos um capítulo da Divina Comédia se não não dá \# 
24'00' E: (risos)

24'01' M: E \#eu li em português depois peguei u::m um canto não um capítulo um canto quase morri mas li \# a tradução pra estudante entã::o sei lá- fui lendo e tal é maravilhosa uma coisa assim que não existe igual então mas eu gosto muito da literatura italiana da literatura italiana gosto muito do:: tem um \# Boccaccio Dante \# isso é o óbvio né?

24'23' M: o:: o:: Petrarca também \# mas um que:: que se- Leopardi \# esse Leopardi eu acho uma coisa \# demais então é um dos meus poetas preferidos e:: o Foscolo il Foscolo <uau que poeta> \#

24'38' E: (risos)

24'39' M: Eu li esses caras no italiano \# (não entendi) assim

24'41' E: O::h muito bem

24'42' M: E:: e::

24'44" E: Mas essas coisas você não viu na sua família \# assim \# não tem nada a ver com a origem com a::

24'47' M: Não não não \# não não não isso eu é que-

24'50' E: Não tinha livros?

24'51"' M: Não não \#

24'52'” E: Não tinha coisa que::

24'53" M: Não tinha livros mas havia culto à leitura a minha mãe que:: se percebe então que ela lia nós íamos à biblioteca comprava livro e tal e minha mãe \#

25'01' E: Olha \#

25'02' M: Não e:: minha mãe lia pra gente antes de dormir aquela coisa assim \#

25'05' E: Hum \# em ita- em português?

25'06'” M: Em português \#

25'07' E: Uhum

25'07' M: E aí ela por exemplo hã:: visa a preocupação com os estudos com a cultura etc havia pessoas muito simples mas voltadas para isso também

25'18' E: Tinha? Não tinha escolas italianas né?

25'20" M: E o que mais \# isso aí me deixava muito- num momento assim meu da juventude eu falei poxa por que não se estuda italiano aqui?

25'27' E: Uhum

25'28' M: Ué por causa dos efeitos da guerra e tal não sei que lá

25'30'” E: Sim sim 
25'31' M: Depois da- quer dizer minha mãe é da primeira geração eu sou da segunda geração entã::o da segunda- terceira geração o pessoal começou a voltar isso e tal 25'39'" E: A recuperar

25'41" M: Isso e isso aconteceu comigo também \# daquela forma espontânea lendo e tal vendo as músicas e tendo isso como normal e a busca dessa cultura italiana foi puxa vida essa é um monumento literário fantástico assim eu não posso- não posso não é possível e tinha um- uma biblioteca pública lá muito boa de leitura então tinha toda a obra no Brasil tinha quinze era o Pirandello

26'14'" E: Ah que legal!

26'15' M: Mas é maravilhoso né?

26'16" E: Ah sim

26'17' M: É um escritor que \# é uma coisa de outro mundo né?

26'19"' E: É bem legal

26'20"' M: Sabe é um grande escritor

26'21' E: É eu adoro assim gosto muito

26'23' M: E:: a:: a:: depois teve a:: gostei das peças de teatro dele que são fantásticas e depois fiquei apaixonado pelo Pirandello até hoje \# mas eu só li há pouco tempo porque eu comecei a estudar italiano aí eu pensei em resolver esse problema peraí também não dá aí

26'38' E: Você foi ler em italiano?

26'39' M: <Claro>

26'40"' E: Aham

26'41"' M: Aí agora eu tô lendo eu li la giara

26'45"' E: La giara uhum

26'46" M: É uma obra prima de tudo aquilo né?

26'50"' E: Uhum \# mas o meu favorito é uno nessuno centomila

26'52' M: <Ah também>

26'53' E: Romance \# esse é o meu preferido \#depois que eu li \#

26'57' M: Mas é- uma outra por exemplo o cinema italiano também o neorrealismo que é maravilhoso \#

27'02' E: Uhum sim

27'04'” M: Aquele negócio assim aquela coisa que- eu já era adolescente aquele (não entendi) \# e o Fellini que era um

27'20'" E: Ah sim 
27'21' M: Desde aquele i vitelloni aquelas coisas todas sabe?

27'22'" E: Uhum

27'25' M: Via tudo né \# Mario Lanza era um cara \# era o nosso ídolo \#

27'29" E: Aliás morreu o Ettore Scola.

27'30" M: Ettore Scola morreu eu vi \#

27'32'” M: Entã::o é:: (não entendi) \# era muito presente assim mas acho que não tem por que esse desprezo pela língua? Não era desprezo eles eram obrigados a deixar a língua isso foi o que desagradou \#

27'48'” E: Sim sim sim

27'50' M: Isso sempre isso sempre deixou assim- foi uma coisa que: isso me deixou assim \# me deu um ressentimento \# poxa por que isso?

28'01" E: Uhum é

28'02' M: É uma língua \# e eu sempre gostei muito de ler \# então tenho um respeito muito grande pela língua \# puxa uma língua dessas se desprezar?

28'10" M: Pus a culpa nos italianos <por que que eles vão jogar fora uma língua dessas? Que gente filha da puta>

28'13" E: (risos) Mas você acha que essa busca assim pelas origens é um movimento só seu individual ou tem mais assim entre as pessoas que você conhece?

28'19"' M: Olha que acho que não viu eu acho que não é só não \# porque eu vejo que existe uma- sei lá- (não entendi) há o surgimento de escolas há também \# de italiano \# há uma consciência mais assim sabe \# nem sempre muito legal mas existe essa consciência uma busca realmente \# não sei se:: se origem outras vezes interessada em alguma coisa \# se:: é::

28'47" E: Você acha que tem momento assim você consegue identificar pensando na sua história um momento em que isso muda em relação a \# tem um momento em que aumenta assim \# essa busca pela italianidade?

29'01" M: Sim sim eu acho que sim tem um momento sim e eu vi isso em várias pessoas mais velhas do que eu mais novas \# e:: em mim também \# falei poxa voue:: sempre circulando por aí e tal \# e não sei que lá \# não tem problema nenhum com isso né?

29'21" E: Não era só assim curiosidade de saber \# porque eu acho que durante um tempo houve quase uma vergonha de ser italiano \# e depois \#

29'28' M: Havia uma vergonha \# isso havia sim \# havia sim \# italiano é pobre não sei que lá 
29'33' M: Eram desprezados e tal \#

29'35' M: Mas há um momento assim por exemplo tem um conto do Monteiro Lobato Jeca-tatu não sei se você já viu \#

29'43"' M: Entã:::o o italiano que era o progressista \# que ele era o cara bacana mas só que você tem um efeito na história que parece que ele que era o vilão não \# Monteiro Lobato tava mostrando o cara que progredia que era um empreendedor que trabalhava que tinha mais cultura e outra eles tinham uma cultura \# os lavradores tinham a cultura do camponês \# e da agricultura da terra \# então os caras progrediam \# avançavam e:: então \#

30'06" E: Uhum

30'07' M: E:: (não entendi) que deu trabalho se acumulando num lugar e etc e isso é um contraste muito grande com a:: outros componentes da população brasileira é tudo brasileiro aí mas é só um começo diferente

30'19"' M: E que há uma a industriosidade eu não tô falando isso como ó:: como os italianos são bacanas não é isso é que uma outra cultura aquela cultura que realmente funcionou o negócio funciona e isso sabe as pessoas falavam com desprezo dos italianos havia isso sim também e comparava um pouco sim mas sabe (não entendi) mas eu era menino e era uma coisa muito difusa né? Mas havia sim isso sabe? Entã::o hã:: uma:: uma coisa muito- ser brasileiro e tal isso é:: tem uma brasilianidade assim realmente eu virava caipiras tudo isso porque não tinha outro jeito né:: (risos) mas é:: 31'16" E: E é interessante pensar em como as culturas se misturam se separam se há momentos fases na história \#

31'18' M: Sim nos caipiras aí é muito legal isso sabe \# você pega aqueles títulos da zona rural da roça e falando:: falando aquele italiano misturado com caipira:: é uma coisa assim muito- eu sempre tenho aquele exemplo do pessoal tudo com aquela cinta por cima da calça que fala assim na venda no bairro <piove para burro > (risos)

31'52'" E: Ah sim

31'53"' M: É muito engraçado assim sabe?

31'56" E: E falando de industriosidade acho que a gente não comentou o que aconteceu com o seu avô depois que:: você chegou a falar que ele virou administrador da fazenda

32'04" M: Administrador da fazenda \# depois aí:: a fazenda isso foi nos anos- final dos anos cinquenta sessenta \# anos cinquenta ainda aí começou o que a industrialização em São Paulo então vieram todos pra cá o meu avô que já estava 
mais velho e tal minha avó meus pais também vieram depois voltaram e tal meu irmão nasceu (não entendi) \# então ficou numa- a família se:: se::

32'42' E: Se transferiu para a cidade grande \#

32'43' M: Se transferiu para a cidade grande e aí muda a coisa então foi indústria automobilística e outras indústrias e tal

32'52' E: Aham \# uhum mas a vida ele fez como administrador da fazenda?

32'58' M: Sim \# ele formou a família foi assim

33'02' E: Essa é uma outra coisa que é interessante observar que:: que aconteceu uns acabaram abrindo uma- um armazém outros hã::

33'09' M: <lsso> tudo isso mas ele não- ele não tinha essa coisa ele fez e aí umauma coisa engraçada que é uma lembrança muito forte que eu lembro da minha mãe dizendo assim <isso de país é bobagem \# ninguém tem país \#país é lugar onde a gente sobrevive e a gente ganha o pão> \#

33'30' E: Ah interessante

33'32'" M: Esse é o país da gente

33'34" E: Quem dizia isso?

33'35' M: Minha mãe

33'35' E: Sua mãe?

33'39' M: Essa é a cultura do imigrante né?

33'41' E: Uhum

33'42'" M: Vamos pra frente \#

33'43' E: Claro

33'44' M: E eu concordo com eles \# sobre os aspectos eu concordo com isso

33'49', E: Sim

33'50' M: Independe de qualquer condição étnica racial culturas não interessa \# o lugar onde você está é o seu lugar \# acabou \# concorda comigo?

34'00' E: Concordo

34'00' M: Você é brasileira \# e não é?

34'04' E: É \# sim agora já sou

34'06' M: Eu sei que você é italiana \#

34'07' E: Eu não tenho não tenho o passaporte brasileiro mas não importa

34'11' M: Não importa \# também não pega \# essa porcaria \#

34'12' E: (risos)

34'16"' M: Pra que você vai querer uma \#? 
34'17' E: Ah tá \# então tá

34'19"' M: Tá bom?

34'20"' E: Tá ótimo

34'21" M: Não sei se foi útil se foi uma \#

34'21" E: Tá perfeito é isso mesmo que a gente faz \#

34'23'" M: E outra coisa você me ajudou você viu que eu tô escrevendo os textos em italiano \#

34'26' E: É eu sei eu vi

34'28'" M: Você viu \# uma coisa \#

34'30' E: É então mas no seu caso a busca da italianidade já está indo mais fundo \# 34'35' M: Porque é o meu idioma \#

34'36' E: Por isso que eu pergunto assim como é com as pessoas que você conhece se tem pessoas que estão num caminho parecido mesmo que tenha outra \# porque claro isso tem a ver com a sua profissão com a-

34'45"' M: Sim sim isso tem a ver comigo com a minha vida \#

34'48'" M: Eu tenho um amigo também escritor e aí eu falei pra ele olha você:: você:: você:: vai tirar a cidadania italiana? <não M. sabe por que? >Porque eu pensei assim ele viaja muito ele fala porque (não entendi) eles vieram escurraçados pela miséria \#foi isso que eles fizeram \# eu vou voltar lá assim \# (não entendi) \# mas isso não me preocupa em nada nada nada \# isso é apenas \#

35'25' E: Um detalhe da história

35'26" M: Um detalhe da história \# a vida é assim as pessoas \# e eu vou ficar com ressentimento \# eles vieram para cá para substituir a mão de obra escrava é isso que aconteceu mas não há nenhuma \# seja escravo puta operário lavrador e o caramba é tudo a mesma coisa gente \#

35'47' E: Aham

35'48'” M: Não vejo essa \#

35'49'" E: Sim

35'50”' M: <Só não pode ser vagabundo aí não dá> (risos)

35'53'" E: <Pronto>

35'54' M: Os vagabundos no sentido dos que não trabalham é isso?

35'56" E: É nesse sentido de que não trabalha entendi

35'58', E: Obrigada M.

35'59"' M: Obrigada vocês espero que tenha alguma utilidade \# 
36'02' E: Ah será com certeza será \# 


\section{APÊNDICE H - Transcrição da entrevista 08}

01" E: Bom \# estamos aqui com a professora N. G. \# que agradecemos por ter vindo aqui participar das nossas entrevistas e:: ela é professora- foi professora agora é professora aposentada da área de espanhol \# e hoje está aqui como no entanto como descendente de italianos \# então por conta da história italiana da família dela \# então obrigada N. por estar aqui e a:: S. começa com as perguntas

28" N: Eu que agradeço o convite

30" E: Ótimo

31" S: Eh:: o que você sabe de como sua família veio para o Brasil?

36" N: \# Olha a:: eu sou- tenho ascendência italiana pelos dois lados materno e paterno \# hã:: do lado materno são meus dois avós eram italianos e:: além disso eu tinha tios avós hã tias que também eram italianas \# do lado do meu pai só a mãe do meu pai era italiana \# bom começo pela família da minha mãe que é que- hã- digamos pelo lado italiano a família pela qual eu tive mais contato \# hã:: \# a minha nonna que era- \# na na certidão de casamento que eu tenho que eu guardo dos meus avós ela aparece como Maria G. mas ela era- eu sei que ela era Ana Maria \# não sei porque tiraram um- um nome dela \# era muito confuso naqueles tempos como os nomes descri- escritos de maneiras diferentes enfim é muito interessante isso \# hã:: mas a minha- hã:: ela veio com doze anos com a família \# ela ela tinha doze anos quando a família veio para o Brasil eles eram de Lucca na Toscana \# hã:: e vieram vei- veio toda a famíla e a família deles era toda de serralheiros \# eles vieram e ficaram em São Paulo \# eles não foram para o interior não foram trabalhar na agricultura eles vieram pra fazer trabalho de serralheria aqui \# tanto que o:: a minha mãe- um dos irmãos da minha mãe meu tio Tulio hã:: tinha- depois ele montou- foi trabalhar com a família quando logo- ainda- de muito criança porque havia muitas dificuldades passaram muitas dificuldades né porque viveram épocas de guerra revoluções enfim hã:: mas ele- portanto eles foram trabalhar muito cedo todos eles os três irmãos né \# hã:: e:: e:: e:: mas hã:: ele tinha uma serralheria que até- até quando o vô faleceu ele era dono de uma grande serralheria aqui de São Paulo \# hã:: então esta família da família da minha nonna veio toda pra trabalhar aqui \# esses eram os G. \# Não é? \# G. por parte de pai \# Pardini por parte de mãe \# então minha bisavó era Pardini e o meu bisavô por parte de mãe era G. \# E ficaram- da família da minha mãe ficaram os G. \# alguns se casaram com italianos né \# o irmão da minha da minha nonna se casou 
com uma italiana do Vêneto e os meus primos eram G. Betti \# então tinha hã:: dois sobrenomes então tinha- entrou mais um sobrenome um outro tio se casou com uma italiana também do Vêneto Bignosi Bignosi B. e aí a minha nonna se casou com o meu nonno \#

03'47"' N: \# Bom a família- hã- no caso da família da minha nonna eles diziam que eram que vieram por necessidades mesmo né e ou seja poucas oportunidades de trabalho lá e vinham em busca da América sem dúvida nenhuma \# no caso da famido meu avô do pai da minha mãe foi diferente ele era anarquista \# e saiu fugido da Itália com dezoito anos e ficou e foi para a Argentina ficou muitos anos na Argentina \# e nesse meio tempo nesse espaço de tempo que ele ficou na Argentina a família decidiu também vir para o Brasil então ele veio já com trinta e poucos anos aqui pra ver a família \# (risos) quando chegou aqui hã:: primeiro se encontrou com a mãe que a mãe tinha acabado de ter uma- uma nenê uma filha \# pra qual ele deu o nome de Argentina \# eu tinha uma tia que se chamava Argentina \# tia avó né muito mais nova que ele muitíssimo mais nova que ele hã e hã:: a família ficou também em São Paulo hã no entanto eu não tenho informações hã sobre as atividades dessa família eu tive pouquíssimo eu conheci essa minha tia hã:: tia avó conheci alguns primos por parte dessa tia mas tivemos muito pouco contato com essa família não saberia dizer o que que eles vieram fazer no Brasil o que que eles eram porque a outra família eu sei bem o que veio fazer né mas essa família não sei a que que se dedicava hã pouquíssimo contato com eles esses eram hã por par- a mãe do meu avô se chamava hã- tinha como sobrenome T. e o- ele meu avô B. tem muit-

05'53' E: De onde eles eram?

05'54'" N: De Ancona

05'57' E: De Ancona

05'58"' N: De Ancona \# hã:: pelo menos o meu avô era de Ancona eu não sei se tinha família esparramada por outros lugares isso não hã:: cheguei a saber \# meu avô então com trinta e seis anos se casa com a minha nonna de vinte e três né \# hã:: com a vontade de ir- voltar pra Argentina não gostava daqui achava que São Paulo era muito atrasado São Paulo era uma província e ele era de Buenos Aires tinha todos os costumes já meu- meu tio era $\mathrm{M}$. depois que eu \# muitos anos depois quando eu tive contato com o espanhol que eu vim entender porque meu a- meu tio era M. e não $L$. no D. D. qualquer coisa assim né mas era por conta da influência já do espanhol né nele hã:: eles tiveram três filhos a terceira filha que se chamava- ada L. morreu com 
um aninho e ele teve uma grande depressão e:: pouco depois minha avó- minha nonna engravidou mas aos três meses de gravidez esse meu avô morreu \# dormindo \# então ele era ele foi uma figura meio mítica na minha infância porque se falava dele que era pra ter ido na Argentina como que como que- ficaram no Brasil que não chegaram a ir pra Argentina podiam ter nascido na Argentina mas nasceram no Brasil \# essa história tinha:: coisas dele tinha um matte tinha um poncho tinha coisas da Argentina e ficou tudo isso eh:: no meu imaginário engraçado que eu trabalhei muito isso em terapia já desses dois lugares meus italiano e de onde veio essa minha- depois essa minha identificação com o espanhol que eu \# por muito tempo eu não entendi o porquê que foi tardia inclusive \# agora já do lado da outra família quer dizer a família do meu pai hã:: aí eles vieram- eles eram do Vêneto a minha avó- pelas informações que eu tenho era nascida na região de Vicenza eu não sei se propriamente na cidade de Vicenza mas não- em algum provavelmente em algum povoadinho alguma coisa daquela região \# essa família veio \# hã:: assim por dificuldades também econômicas e eles vieram- eles eram eles tinham dois sobrenomes L. B.\# L. era por parte da minha bisavó paterna e o B. era por parte do meu bisavô paterno meu pai era D. B. M. \# então essa família- minha avó chegou relativamente pequena não sei dizer exatamente a idade mas eles todos- hã mas chegou com a mãe a mãe veio o pai já tinha falecido \# conta-se na família que o meu avô teria morrido durante o trajeto e que foi atirado ao mar o corpo \# então chegou a família \# hã:: chegou- chegou a minha bisavó com duas filhas mulheres e um filho homem \# hã:: que- hã:: e- e que- hã- essa família toda foi para uma casa de família eles foram trabalhar numa casa de família hum de gente muito rica \# eram os G./ L. \# eu não sei se vocês já já ouviram falar eram gente muito de muito dinheiro que tinham grandes empresas empresários hã:: provavelmente de origem inglesa ou norte americana eu não sei identificar isso hã mas eles eram donos de grandes indústrias tal e minha- toda a família da minha avó inclusive os filhos ficaram durante muito tempo morando no casarão dos L. que era um casarão muito grande que ficava ali na regi- próximo do da da rua Maria Paula do viaduto Maria Paula onde durante muito tempo depois funcionou-por isso que eu imagino que os Lee eram eram \# norte americanos porque durante muito tempo funcionou ali a União- uma escola onde até eu estudei União Cultural Brasil-Estados Unidos e foi muito interessante porque eu fui estudar nesse casarão depois ele foi derrubado né hã:: fui estudar nesse casarão fui estudar inglês nesse casarão sabendo que a minha família que parte da minha família tinha morado ali eles foram trabalhar 
de governanta de provavelmente de copeira empregada eu não sei exatamente todos os serviços que faziam mas era nessa família que era gente muito rica era um casarão enorme era assim um palacete muito grande \# então são esses dois lados que vieram dessa forma as duas famílias mas as duas famílias ficaram em São Paulo eu não conheço- não sei- pelo menos eu não conheço ninguém das minhas- dos dois lados que tenham ido para o interior trabalhar em lavoura \# eu sei que tem muito $G$. no interior de São Paulo \# poucos B. aqui eu encontrei muitos B. na Argentina mas poucos aqui e B. pouquíssimos pouquíssimos também \#

11'51" S: E você lembra de alguma história sobre a Itália que se contava na sua casa? 11'55" N: Bom \# a:: as histórias que se contavam da Itália na minha casa vieram or via da minha nonna \# porque a minha nonna era viúva e sempre morou conosco então ela ficou morando com a minha mãe e:: e aí evidentemente esteve presente até:: ela morreu eu tinha quase quin- perto dos quinze anos de catorze pra quinze anos então eram- as minhas histórias da Itália vem por ela \# então ela contava- eu me lembro que brincavam muito com ela- meu pai brincava muito com ela que dizia que ela era extra muros e ela ficava muito brava porque ela dizia que ela era de dentro que ela era intra muros né \# que ela era luquesa mesmo que ela hã \# era de citadina que se falava?

12'46" E: Sim aham

12'47' N: Não era

12'48' E: Sim

12'49' N: Não era camponesa não é?

12'50' E: Aham

12'51"' N: E ela então contava as histórias cantava muitas músicas músicas infantis tinha uma que ela cantava que eu me lembro \# da chuva piove piove il cielo l'acqua di San Pietro la gatta si bagnava perché ti bagni i gatta \# então eu fui embalada com todas essas essas coisas né \# e aí ela- e aí a gente fazia perguntas pra ela e então ela contava de quando ela era criança de como era de como era os muros de como era a muralha de como era Lucca que era uma cidade toda com muralhada e que então contava dessa história que ela ficava brava que dizia que ela era de fora e ela dizia que ela era de dentro que ela tinha sido batizada numa igreja que chamava Chiesa di Santa Maria que eu fui \# quando eu fui a Lucca fui ver essa igreja e que ela lembrava da época em que nevava e que eles faziam os bonecos de neve e:: cantavam músicas quando faziam os bonecos de neve então toda a minha história toda toda a minha infância foi povoada por essa por essas histórias muito fortes num 
é e:: então era era- no meu imaginário \# pra mim \# ir pra Itália era uma coisa assim era sonho muito grande e o:: mas o sonho- claro que eu queria ir a Roma ir a outros lugares a Veneza tudo estive em tudo isso mas meu grande sonho era ir a Lucca \# o meu grande sonho era ir a Lucca e:: a tal ponto de quando eu cheguei em Lucca eu tenho uma foto inclusive que o:: o M. meu marido bateu hã:: quando eu desci do trem e pisei em Lucca eu caí em prantos porque era assim- era uma coisa hã:: mágica pra mim estar ali e:: vendo aquela cidade eu sentia que meus olhos não eram só meus eram os olhos da minha mãe dos meus- dos meus tios né dos meus primos do meu irmão que que porque né porque Lucca era a grande cidade a grande protagonista das histórias nossas né \#

15'05' N: o meu avô como eu digo eu não o conheci a minha mãe não o conheceu então era era uma figura meio mítica e era tinha toda essa história ele não se sentia italiano ele não gostava rejeitou a Itália porque a Itália o expulsou num eh:: não havia grande contato com a família dele eh:: aqui e por outro lado toda a coisa dele vinha pelo lado argentino e não pelo lado italiano num é ao contrário a minha avó sempre dizia ele num queria ele num era italiano ele se dizia argentino e minha outra avó \# eu \# até estranhava de que ela- qu dissesse- de saber que ela era italiana ela não tinha \# praticamente nada de italiano que eu me- ela não tinha sotaque ela veio criança muito pequena né veio criança não tinha sotaque e se casou com um brasileiro meu outro avô era \# era da- da- da região do era Rio do Estado do Rio da Baixada Fluminense eles eram fazendeiros tal enfim era- tinha outra história e:: eu me lembro a minha mãe contando histórias assim de que na época da guerra foi muito complicado porque do lado da família do meu pai eles negavam essa- esse lado italiano e a minha mãe da família da minha mãe não eles eram eles marcavam porque havia toda a história do Mussolini estar do lado do Hitl- enfim todas essas histórias geraram problemas de família muito grande né muito fortes

16'45' S: E:: se falava italiano na sua casa?

16'48' N: Bastante \# qual italiano que italiano era esse eu não sei te dizer mas bastante \# eu cheguei quando criança eu cheguei a falar um pouco de italiano com a minha com a minha nonna meu tios- minha mãe hã:: falava um pouco mas dos filhos todos a minha mãe talvez a que falasse menos a minha mãe já misturava muito e:: falava:: \# metade português metade italiano mas falava italiano quando precisava falava italiano com a minha nonna quando precisava e:: mas eu tenho um- eu tinha um tio meu tio esse que era o serralheiro do meio ele era impressionante ele falava 
muito mal o português muito mal falava o potuguês com um sotaque impressionante como se ele tivesse nascido e vivido na Itália e no entanto ele já não era nascido na Itália já era nascido no Brasil num é \# os homens os dois homens e ele- pra mim- esse meu tio Tulio o outro era Luiz também esse meu tio Tulio era o que mais fortemente italiano era ele era \# muito italiano e assim ele fazia questão de mostrar que ele era muito italiano né \# e:: e depois nas reuniões de família nos tinhamos uma família hã:: família por parte da- da- da minha nonna tinha um irmão da minha nonna que era vivo e casado com uma que era de Ferrara a outra minha- a outra minha tia também era do Vêneto e tal então eles se juntavam se reuniam e nessas reuniões só se falava italiano e:: eu me lembro eu tinha um primo que era mais ou menos da minha idade e nós fazia- nós fingíamos que nós não entendíamos pra eles falarem porque aí eles falavam tudo e a gente a gente dizia que não entendia eles falavam tudo que a gente não podia ouvir em italiano e a gente entendia a gente fingia que não entendia mas na verdade a gente entendia (risos)

18'50' N: Então era um itali- era um não era que eu falasse fluentemente mas era um italiano- falava algumas coisas e tinha um italiano passivo num é assim de entender agora provavelmente um italiano que já tinha muitas transformações que devia ter coisas dialetais porque por exemplo eu sempre- eu acho que eu já até falei disso pra E. né \# a vi- o léxico e sobretudo o léxico da comida era muito italiano né então a gente comia carciofi a gente não comia

19'24' E: Alcachofra

19'24" N: Alcachofra né mas a gente comia murinhana na minha casa e não como é que é?

\section{9'29'" E: Melanzane}

19'30" N: Melanzane né \# então era é- zucchini essas coisas né o:: o nome das comidas era:: o nome das verduras das das coisas assim era muito marcado pela influência italiana né então ficou- o tipo de alimentação também era muito forte \# na minha família num- nós nunca tivemos o hábito assim hã:: de comer sei lá o feijão arroz e uma mistura \# feijão e arroz era no dia que se fazia ei lá tinha um dia na semana que se fazia feijão que era:: uma outra comida que se fazia mas no num era assim todo o dia comer feijão com arroz né e:: a coisa da mistura não era mais uma alimentação no estilo italiano muito brodo átodos essas- isso tinha que era era sagrado às vezes mesmo que se comesse outra comida tinha nem que fosse só o caldinho assim tinha e:: a massa feita em casa né os molhos os- enfim as várias comidas 
italianas e algumas comidas inclusive que vieram por lado desses tios e tias do lado Vêneto né porque mesmo- por parte do meu pai a influência do Vêneto não foi muito grande mas por parte da família da minha mãe que tinha hã Vêneto- dois um tio-avô casado com uma do Vêneto um tio- casado com do Vêneto a gente aprendeu comidas do Vêneto então eu aprendi eu faço um macarrão que eu- ficou batizado na minha casa de macarrão de saco que é- que vai no saco cozido no saco assim que é uma comida vêneta né e:: que depois eu descobri receitas diferentes receitas num é eh:: zuppa imperiale tem um monte de nomes

21'28' E: Precisamos marcar um almoço hein N.? (risos)

21'30' N: Precisamos fazer né? É verdade precisamos fazer

21'32' E: Você já me contou alguma coisa desse macarrão \#

21'33' N: É mas ficou muito influenciado por isso mas depois que minha nonna faleceu parece que o italiano ficou uma uma língua proibida foi muito engraçado isso mas falava sim bastante \#

21'46" E: E na época em que era proibido mesmo assim você sabe o que aconteceu na sua família?

21'51' N: Eu nessa época eu não saberia te dizer porque eu- foi anterior né? Eu nasci no fim da guerra

21'59' E: Eh::

22'00" N: Hã:: mas a:: a:: que eu sei que havia tensões havia muitas tensões eu sei que a minha mãe chegou a ter desentendimentos com a família do meu pai- com a sogra né basicamente porque eles queriam esconder o lado italiano e minha mãe dizia não \# porque eu vou esconder meu lado italiano? Meu pai e minha mãe meu pai e minha mãe não têm culpa do está acontecendo e não tem porque negar porque havia havia um- uma pré-disposição negativa eu sei que havia muita- eram xingados mas eu mesma não vivi esse momento num é \# meu irmão que lamentavelmente não está vivo ele viveu porque ele era dez anos mais velho que eu ele viveu esse período num é \# hã:: viveu época de guerra com os racionamentos tudo eles contavam isso mas eu só sei disso por histórias mesmo porque eu num \#

23'00' E: Eh mas eu perguntei por isso pensando que eles podiam ter contado porque essa história em muitos lugares acabou fazendo perder o laço com a língua com \# 23'10" N: Pois é mas havia mesmo havia eu sei que isso minha mãe sempre contava que na família do meu pai eh:: tanto que meu o pai era dos poucos- dos dez irmãos era praticamente o único que usava $B$. que se registrou como D. B. M. os outros todos 
tinham só sobrenomes do pai que era $M$. M. os meus tios são $M$. M. então não se colocou em grande parte para que não se percebesse a a- né \# [23'46" E: ah:: que interessante] e \# na família do meu pai se apagava se ocultava o lado italiano isso eu sei né \# durante muito tempo e na família- depois isso \# passou aí as pessoas- né porque eu me lembro que eu tinha uma tia que era uma das minhas tias também \# mais velhas que era como meu pai também que cultivava muito esse lado italiano minha tia Irene e ela tinha ela fazia coisas muito- fazia comidas que eram venetas fazia coisas que era italianas eu me lembro que ela fazia:: eu não sei até hoje como se diz porque hã- tinha parte da minha família que falava de um jeito e parte que falava de outro uns falavam crustoli e outros falavam grostoli

24'38'" E: Uhum \# um doce?

24'39" N: Um doce e ela fazia de um jeito que a minha avó sabia fazer que a mãe dela sabia fazer e que eram- porque na minha na na- ela fazia umas bolinhas e depois montava essas bolinhas com uma calda e tal e do outro lado da família era um que fazia que nem um lacinho assim eh:: que se come muito no Rio Grande do Sul eles chamam de cueca virada alguma coisa assim (risos) [25’04"' E: No Sul?] no Sul é tem um nome muito engraçado mas é o grostoli e se você for no o Zaffari aqui que tem um mercado Zaffari que é gaúcho que é ali na no:: shopping Bourbon é um mercado gaúcho mas Zaffari né Zaffari [25'23”'E: Sim sim] e eles fazem lá você compra grustoli assim feito lacinho \#

25'29" E: Eu acho que dessa comida tem muitas variantes regionais por isso tem nome diferente

25'34" N: Eh eu imagino que sim

25'35' E: Porque a mesma coisa chama de um nome completamente diferente lá \# 25'40" N: Mas é engraçado como aqui também as coisas se misturaram né porque por exemplo \# eu sei que na Toscana hã:: o tomate não era uma coisa assim num era num era tão forte na comida Toscana como no Sul e no entanto na minha casa se fazia muito molho de tomate se usava muito tomate então se vê que aqui eles- houve também uma uma mistura das várias partes da Itália né \# e eu me lembro que se fazia muita brincadeira entre eles então chegava um e falava assim eh sei napolitano por causa da fala ou calabrês era- tinha calabrês era- tinha \# uma marca forte [26'30" E: A fama] calabrês e napolitano era tinha uma marca mais forte os do Norte da Itália era mais \# (risos)

26'37' E: Legal 
26'38' N: Então havia todas essas e- e:: a o por exemplo pros eu me lembro que pro Vêneto- pros vênetos falava magna bigoli \# ah:: você é magna bigoli \# magna bigoli é aquela massa né que eles fazem lá [26'52'” E: Uhum] eu comi bigoli lá (risos) eu provei todas as coisas que povoaram \#

26'57' E: Então você nasceu num lugar havia muitos italianos o lugar onde eles moravam

27'01" N: Havia o Brás eles moraram

27'02"' E: No Brás

27'03'" N: O meu pai nasceu no Bixiga [27'05'” E: Uhum] a casa do Bixiga até hoje tá lá meu pai foi bati- meus tios meu pa- meu pai e meus tios foram todos batizados na Achiropita né então eles eram de lá depois o meu- meu avô abriu uma loja de calçados na Avenida Celso Garcia \# era Celso Garcia ou Rangel Pestana porque ela ela muda de nome bom era ali no Brás e foi aí que eles vieram morar ali e ali que meu pai e minha mãe se conheceram porque minha mãe sempre no Brás

27'35' E: Entendi

27'36" N: Brás Mooca Brás tinha era a gente tinha família toda ali naquela região era outra coisa o Brás na época num é agora o Brás virou \# é outro mundo né num tem nada a ver com a época deles era era o Brás era a região forte Brás e Bixiga né os dois lugares muito fortes de imigração italiana

27'56" E: Brás e Bixiga

27'57' S: E como você acha que foi ser italiano em São Paulo? O que você acha eh:: que se pensa dos italianos no Brasil e em especial em São Paulo? No caso da sua família

28'09" N: Bom olha eu sei como eu te digo que:: durante muito tempo hã:: eles passaram muita dificuldade né não foi fácil tanto pros que vieram porque essas coisas a gente sabe não apenas pela família mas por por tudo que a gente aprendeu por leituras até pela literatura não é eu li toda toda essa literatura Brás, Bixiga e Barra Funda hã:: Anarquistas Graças a Deus porque essas coisas digamos tem muito a ver com a minha relação familiar com a minha formação mas hã:: havia posições diferentes havia facul- digamos segmentos que negavam sobretudo na época da guerra né \# a época da- eu acho que a época da guerra foi muito forte porque quando eles vieram e chegaram que não era ainda foi antes da guerra minha nonna chegou aqui eu acho que:: deve ter sido muito no início muito no início do século XX porque 
bom meu pai era de 1905 minha mãe era de 1910 então eles chegaram no fim do século XIX eles eram nascidos no século XIX num é

29'29"' E: Uhum

29'30' N: Depois a gente olha aqui em que ano se casaram

29'31' E: Porque você falou aqui que ela tinha doze anos quando chegou

29'34' N: Ela tinha doze anos quando chegou deve ter vindo em mil oitocentos e:: no final do século dezenove [29'39'” E: Dezenove] num é e:: hã:: quando chegaram aqui é o que eu sei é que:: pra eles foi um grande choque porque era um mundo completamente diferente então tinha histórias até engraçadas eu me lembro que minha tia hã:: que tinha um nome até estranho que eu nunca vi o nome dela em lugar nenhum essa que veio do Vêneto que se casou com com meu tio T. ela se chamava A. A. M.

30'10' E: Uau

30'11' N: Nome- nunca ouvi em ninguém foi a única pessoa na vida que conheci com esse nome e eu me lembro que ela disse que ela contava que tinha gente que tinhanum sei quem deles que foi comer abacaxi e comeu a casca do abacaxi passou mal (risos) ou que a minha nonna que contava que via por com tanta coisa no no feijão assim e dizia nossa como eles põem queijo ralado no feijão e era farinha (risos) então essas- contavam essas histórias havia muito preconceito na minha família essa famia família que era mais italiana digamos né esse segmento da família havia até um certo preconceito isso é coisa de brasileiro havia preconceito havia preconceito com brasileiros havia preconceito com negros \# meu tio por exemplo esse meu tio que era muito italiano ele chamava os negros de tedeschi tedesco alemão

31'08' E: Ah:: por que tedesco?

31'10' N: Era uma ironia né? Era uma ironia alemão tudo branquinho né

31'14' E: Ah:: entendi::

31'15" N: Olha lá o tedesco [31'16" E: Olha:: ele foi até pro] olha olha foi pro outro lado olha como eram as coisas né e o filho dele se casou com uma mulata olha como são as coisas a gente paga a língua (risos)

31'28' N: Então era:: havia n- havia preco- eu acho que havia preconceito de parte a parte uma situação eu vivi mais o preconceito dos brasi- dos italianos com relação aos brasileiros do que o contrário porque eu não vivi essa época \# Agora na época da guerra havia muito preconceitos preconceito com o italiano né:: hã::\# mas eles se adaptaram e:: bom muitos fizeram fortuna isso é sabido né tanto no interior quanto no 
né no aqui na capital os famosos Matarazzos os eu gosto muito das peças também do Jorge:: \# meu Deus eu num \#

32'18'" E: Ah tudo bem

32'21' N: Bom Os Ossos do Barão porque é que justamente um imigrante italiano que enriquece por conta do café que se casa com uma quatrocentona enfim todas essas coisas eram- são muito faladas tão registradas na história na literatura na literatura tem coisas muito interessantes sobre essa época da da imigração né até nas novelas da Globo algumas coisas apareceram \# bem globalizadas mas elas apareceram né (risos) tem várias novelas que falam disso mas o meu registro é um pouco esse eu nunca tive problemas eu ao contrário sempre me orgulhei muito e sempre quis hã:: manter a memória cultivar ler a respeito hã saber fui pra Itália mais de uma vez hã adorei hã é uma emoção muito grande e eu sinto que há um lado meu muito italiano \# muito italiano ainda (risos)

33'16' E: Você acha que tem na na mentalidade assim na percepção dos brasileiros ainda hoje traços da italianidade que ficaram de alguma forma assim estão no discurso na cabeça das pessoas? Quando se pensa em italiano no o que que se pensa?

33'39' N: Eu acho que existe hã:: que ficou muito um estereótipo também \# eu acho que há uma estereotipia muito grande aí né \# ou seja porque se você pensar no italiano que que- quando você conhece a Itália e os italianos você pode identificar muitos traços que estão na nossa cultura sobretudo pra nós paulistas né e provavelmno Sul também né mas você vê que há outras coisas que não né que ficaram como estereótipos num é hã:: mas eu acho que existe eu acho que que hã São Paulo sobretudo hã guarda e acho que bo bom pra começar na sua fala eu acho que é uma fala é eu talvez consiga identificar em mim mesma só quando eu me ouço gravada mas eu identifico até em pessoas que não eram descendentes de italianos é muito engraçado por exemplo eu vivi num bairro que era um bairro de muita imigração né então tinha nesse bairro a minha vizinhança eu tinha vizinhos italianos vizinhos portugueses vizinhos árabes ã:: espanhóis tinha- era um bairro que coincidentemente na minha rua era assim eu dizia parecia nações unidas né ali porque eram hã todas as famílias que moravam naquela rua e com as quais a gente mantinha uma relação muito próxima porque era bairro bairro mesmo era todo mundo se conhecia todo mundo ia na casa de todo mundo quem fazia coisas da sua terra dava pra vizinhança toda era assim era era muito era muito gostoso aliás era uma vida muito simples mas muito gostosa eh e eu tinha vizinhas que eram filhas de portugueses e que falavam 
de um tão falam até hoje algumas eu eu ainda conheço falam mais italianado do que eu entendeu aquela fala mais cantada assim é muito engraçado e isso você sente e com isso se faz piada evidentemente claro que isso foi de um momento do italiano num é a mesma coisa que dizer fala-se italiano bom fala-se italiano que italiano é esse né? É a mesma coisa do alemão em certos lugares do Sul ficou um alemão que nem existe mais na Alemanha né nem se fazem entender porque ficou uma uma língua que num ou que se evoluiu foi evoluindo numa mistura né numa numa coisa assim mas eu acho que existem traços na nossa- no nosso em alguns modos de ser do paulista- do paulistano sobretudo e algumas cidades do interior também onde houve muita imigração hã:: muita presença do colono né do italiano na na no campo né mas onde eu mais senti onde eu sinto muito forte é no Sul existem regiões do Rio Grande do Sul em que eu estive que é impressionante eh:: é realmente mas sempre é de uma Itália que provavelmente não existe mais eh:: das coisas que eu vi na Itália foi muita pouca coisa parecida a essas coisas que você vê no Sul no Brasil então acho que ficaram existem traços mas traços de um momento da Itália que não é necessariamente a Itália de hoje [37'15" E: do que é hoje] que a Itália continuou andando a mesma coisa com as outras com a Espanha com Portugal também foram ficaram numa época né [37'25" E: uhum sem dúvida] essa memória se cultiva se cultiva mas depois quando vo- quando você coloca essa memória em enfrentamento com o real de hoje daqueles povos você vê que bom lá muita coisa mudou então \#

37'42" S: E você lembra se era lido algum jornal em italiano na sua casa?

37'46" N: Na minha casa me lembro da Fanfulla me lembro da Fanfulla me lembro até de ter visto exemplares da Fanfulla ter folheado porque eu acho que nem lia nessa época \# mas hã pode ser que houvesse outros mas na minha memória o que eu me lembro mesmo era a Fanfulla

38'12" E: Quem lia?

38'14"' N: Hã:: os meus tios a minha mãe a minha nonna na casa da desse lado da família desse lado da família \# eles assinavam vinha sempre eu me lembro que chegava acho que chegava não sei se chegava pelo correio se era uma entrega isso eu não me lembro mas ele tinham a Fanfulla em casa

38'35' E: Interessante

38'37' N: Tinha outros jornais que havia? Eu não me lembro \#

38'40" E: O Fanfulla eh foi o jornal mais difundido né a notícia que se sabe é que em 1907 depois do Estadão era o jornal mais lido de São Paulo mas houve mais de 600 
títulos publicados em italiano entre todos né até aqueles de número único teve jornais semanais várias possib- entre todas as possibilidades houve mais de 600 títulos publicados em italiano \# e um outro que foi bem importante foi um chamado La Difesa [39'13'” N: Não esse não me lembro] esse era pra parte anarquista da sua família porque esse era [39'17'' N: É mas o meu avó já não era vivo] é já não podia mais ele não deixou herdeiros do anarquismo porque aí essa esse era um jornal que ficou mais assim nasceu foi fundado bem mais tarde e teve toda uma outra história o jornal mesmo dos italianos era a Fanfulla era esse mesmo

39'36" N: Esse eu me lembro muito bem muito bem é como se eu tivesse vendo aqui 39'40"' E: Que interessante \# legal 39'43"' S: Então é isso obrigada N.

39'45' $\mathrm{N}$ : Eu que agradeço é gostoso lembrar essas coisas

39'48' E: Eh:: foi ótimo linda entrevista 


\section{APÊNDICE I - Transcrição da entrevista 09}

C: Então D. A., se a senhora puder começar contando, mais ou menos, como que a família veio pro Brasil.

A: É, então, isso acho que seria interessante, né?

C: Sim

G: Seu pai né

A: Quando vocês quiserem que eu comece, eu começo

$\mathrm{N}$ : Já começou

0'21" A: Bom, então é o seguinte. A minha família é toda italiana, meu pai, é, morava na Itália, com mais, é, eles eram em cinco irmãos, sendo que o irmão mais velho veio pro Brasil, foi morar em Guaratinguetá e a irmã foi morar no Rio de Janeiro. E ele, com treze anos, ele acho, ele quis, quis vir pro Brasil, mas não conhecia nada, não tinha idéia de nada. Pegou um navio de carga, desceu no Porto de Santos, dormiu debaixo de ponte, até ele descobrir como iria pro interior pra encontrar o irmão, ele ficou vagando pela rua. Aí ele foi pra lá, aí ele começou a trabalhar junto do irmão, meu pai era alfaiate, então ele começou a trabalhar e foi desenvolvendo, crescendo, aí ele saiu de lá e foi morar em Taubaté. Aí quando, lá ele fundou, ele tinha uma associação de, como tem aqui o círculo italiano, eu acho que lá também tinha e ele que organizava tudo, cuidava direitinho de, da documentação, mas ele era uma pessoa muito interessada, mas muito mesmo, por tudo do Brasil, ele falava um português corretíssimo, lia, lia muito, muito, muito, ele, eu peguei pra mim até, ele tinha a Enciclopédia de psicologia, coisas de culinária, tudo relacionado ao Brasil, de tanto que ele gostava. e o meu nome, eu me chamo A. R., por que? Porque uma irmã dele chamava A. e a outra R., as duas que ficaram na Itália, e uma coisa que eu não, e ele, todo o dinheirinho que ele conseguia, ele mandava alguma coisa pra Itália pra, pra família, pra mãe que ficou lá, né? Porque eles tinha plantação de castanha, é, eles plantavam castanha.

C: Ele veio sozinho pro?

2'31" A: Sozinho, sozinho, sozinho. E aí foi crescendo, desenvolvendo, até que ele acabou casando, né, e aí começou a família dele, e ele pretendia um dia poder voltar pra ver a família, mas não conseguia, né, só trabalhar, trabalhar. Uma coisa que ficou assim, uma coisa que eu não vou esquecer nunca foi o dia que ele recebeu uma carta da Itália dizendo que a mãe tinha morrido, ai, judiação, como ele chorou, viu, é incrível, 
ele chorou, chorou. Mas cê vê, olha, com esse trabalho todo dele, ele conseguiu uma família, cinco filhos, também, e ele deu uma educação pra gente de primeira, a gente teve uma vida muito, muito decente, muito boa, tudo com, com o trabalho dele. Ele, no final de semana, o que que ele fazia? Por que no interior, antigamente, setenta anos atrás, não existia fogão elétrico, não existia nada. Então, vinha um carro de boi com toras de madeira, colocava lá no quintal, e ele passava o final de semana rachando lenha, pra poder acender o fogo, pra gente poder ter água quente pra gente poder tomar banho, cê já, cê já imaginou? Que vida, não? Era uma coisa assim, então, na minha casa era uma maravilha, a gente tinha aquelas parreiras de uva, como tinha na Itália, limão siciliano, tinha tudo, tudo que se relacionava à Itália...

C: $E$ isso era em Taubaté, né?

4'05" A: É, era em Taubaté, ele sempre ficou morando lá. Mas ele era assim uma coisa, a gente tinha uma, uma, uma identificação muito grande, muito grande, tanto é que o meu primeiro trabalho, quando eu me formei professora, que eu arrumei uma escola em São Caetano do Sul pra trabalhar, não sabia nem onde ficava, pois ele veio junto, foi conhecer o local, quem era, onde era, como é que eu ia, onde é a pensão que eu fui morar, olha, era uma pessoa...

C: Ele era um pai super dedicado, né?

4'38" A: Não... é, é. era fabuloso! Uma coisa que eu sempre falo que, que é, é um exemplo. Eu herdei muita coisa dele também, essa independência, essa, hum..., essa, aventureira, e a minha filha que mora na Itália também puxou muito esse lado dele, tanto é que com dezenove anos ela se mandou do Brasil e foi pra Itália

C: Independência, né.

5'04" A: Foi, foi morar lá, deu um duro danado, também, dormiu de, de, nessas barraquinhas, debaixo de árvore, também, até conseguir se estabelecer lá. Então, ele, ele doou muita coisa dele pra gente, né?

C: Muita coisa boa.

5'24" A: Muita coisa legal...eu...quando eu fico vendo as coisas todas, era assim uma, um exemplo. Um exemplo de vida. Você imagina, uma criança de treze anos entrar num navio de carga prum, prum lugar que você não sabe onde você tá indo, há uns oitenta anos atrás.

C: Que loucura, né.

5'43" A: O mais engraçado é que na minha casa tinha, (inaudível), a gente tinha uma foto enorme, que ele adorava, do Mussolini, a minha família deu um fim nela, ai que 
pena, eu pegava pra mim. Mas ele tinha lá na sala, aquela foto enorme, porque era, acho que naquela época, acho que eles tinham um culto ao Mussolini

C: Ele era muito popular, né?

6'12" A: É, eu acho que sim, né. Mas olha, final de ano, o que ele trabalhava, às vezes ele não tinha condições de voltar pra casa e ele dormia em cima do balcão onde ele costurava. Então, você pensa bem, você deixar cinco filhos, numa situação boa, estudando em bons colégios, uma vida decente? É a custo de trabalho, não tem outra maneira, né? Teve que trabalhar muito.

C: E naquela época, tudo muito mais difícil, né, inacessível...

6'43" A: Tudo. Não existia, como agora tem essas lojas que vendem tudo prontinho, né? Antigamente, não, era tudo fei, e eu me lembro muito que na cozinha da minha mãe tinha, ele fazia linguiça em casa. Então, pega, ele fazia, fazia, vai enchendo aquela tripa, né, depois fica tudo pendurado, assim (risos)

G: É bem típico, mesmo, né?

7'07' A: Bem típico, e o tremoço também, nossa senhora, tinha também, tudo, tudo o que se relacionava à Itália a gente tinha em casa. Mas eu nunca esqueço disso, aquelas, monte de linguiça, tudo pendurada ali

C: Pra secar, né?

7’24” A: Pra secar, né? Coisa incrível! Não, olha, a gente, não dá pra esquecer, não dá.

G: Marca o resto da vida, né?

7'34" A: Ah fica, fica. É um exemplo de vida, né? Porque você agora não vê ninguém que faça isso. Você vê os garotos agora, o que que eles fazem?

C: Tudo pronto, né?

7'46" A: Tudo pronto ali, e outra coisa, só ficam ali na internet, no vídeo-game, num, num, num, não aprende a conhecer a natureza, né, não tem contato com a natureza, não tem nada, né? E é tudo, os papai e mamãe bancando tudo, eles não tem problemas pra, é, já, então, mas nesse ponto os meus filhos herdaram algumas coisas mesmo porque você vê a minha filha foi embora com dezenove anos, meu outro filho também foi passar um ano na Itália, também, vivendo ali à custa dele, trabalhando de lavador de pratos, de, de tudo. Trabalhava de tudo pra poder ter dinheiro pra sobreviver, e a minha filha também, já trabalhou de babá, de, trabalhou em hotel de camareira, enfim, tem que, hã, por exemplo, tem épocas de colheita de morango, por exemplo, então lá eles, e foi lá que ela conheceu o marido, colhendo morango, 


\section{G: (inaudível)}

8'53" A: É, na colheita, porque todo mundo trabalha nisso.

G: Não é vergonha.

8'57" A: Não! Não é vergonha, uma coisa que eu acho muito bonito, na Europa, principalmente na Itália, não existe essa diferença de, de, sabe, no mesmo lugar, no mesmo restaurante você vê um advogado, um médico, um operário, um, tu, todos iguais, não tem essa discriminação como tem aqui e uma outra coisa que eu admiro, e eles têm assim um, eles viv..., eles pretendem ter, qualidade de vida, é viver bem, comer bem e passear, não é? Aqui já é totalmente diferente...

C: Aproveitar o tempo que tá (inaudível)

9'36" A: Aqui já a gente tem um hábito totalmente diferente.

G: Tem algumas dificuldades a mais

9'43" A: E, não. todo mundo gosta de aparecer. Então eu acho que, ainda os costumes europeus, principalmente dos italianos, são muito diferentes, muito, e eu vou lá todo ano, eu sei, eu acompanho né, é incrível, viu, eles, apesar da dificuldade que eles estão, terríveis, né? Mas eles vivem, eles vivem decentemente.

G: E, e a senhora herdou alguma coisa dessa, dessa culinária?

10'11" A: Ah, eu adoro fazer macarrão feito em casa, com a mão, eu, eu, eu não vivo sem. Adoro mexer com a mão, adoro plantar também, cultivar. Olha aqui ó, eu, eu não tenho nada. Mexer com a terra. Não, eu, eu, eu, eu herdei muita coisa, muita, muita mesmo.

G: Interessante.

10'32" A: Não, graças a Deus, eu não me arrependo, não. E também criei meus filhos numa linha, direitinho, né.

C: Sim... E, e de histórias, assim, a senhora lembra de alguma história que o pai contava de, da Itália, de lembranças dele?

10'49" A: Isso acho que ele quase não falava, e eu acho que ele não falava porque ele sentia tanta ausen..., tanta falta que aquilo pra ele fazia mal.

C: Machucava.

A: Machucava, então, não, ele vivia o Brasil, entende? Então ele não falava, não falava quase nada da Itália. Incrível, né?

G: Acho que era uma proteção. 
11'18" A: Não, eu acho que ele fazia isso pra não sofrer, né, porque, pensa bem, né, ele querer voltar pra lá e não conseguir ter voltado, nunca mais voltou. Nunca mais voltou. Olha que judiação.

C: Aí, aceitou a realidade aqui, né, e fez tudo o que pôde pra viver bem aqui.

11'34" A: E o lugar, a região que ele morou, nasceu é uma região bonita, aliás, a Itália toda é bonita, né, não tem uma, cada região tem uma característica diferente, né, então não tem como falar aquele lugar não é bonito, né? Não é verdade? Sempre assim, e o que eu me lembro que ele falava era isso, que eles plantavam castanha, isso só. Isso, hã, plantação de castanha, né?

C: $\mathrm{E}$ dentro de casa em Taubaté, ele falava italiano ou...?

12'06" A: Não. Nada. Ele falava o português. Porque ele dizia que ele estava morando no Brasil. Nunca tentou ensinar a gente a falar italiano. Incrível, né? Nunca, ele nunca falou uma palavra em italiano.

C: Mas a senhora fala hoje?

12'22" A: Sim, porque a convivência, tudo, né? Mas ele não, ele não falava italiano e só falava português. Mas então, e o que, tem uma coisa muito interessante, ele adorava assistir à São Silvestre. Naquele tempo a São Silvestre era meia noite, então ele tinha aquele rádio enorme na sala e a gente naquela, naquele horário não podia fazer nada. Tinha que assistir à São Silvestre. Por isso que eu faço todo ano a São Silvestre, pra homenagear o meu pai. É, todo mundo sabe, uma matéria que eu fiz, na revista, eles queriam saber o porquê, né? Aí eu disse por que que era, porque pra ele a São Silvestre era uma coisa, são coisas engraçadas, né. Como ele gostava das coisas do Brasil, né?

C: Sim, ele tomou com pátria dele também, né?

13'14" A: Mas imagina, ele adorava, mas é estranho ele assistir a São Silvestre. Ele não era nenhum atleta, não era nenhum esportista, não era nada, mas ele gostava. Então, era assim, bem, bem, bem diferente. E na minha casa a gente tinha todo aquele tipo de planta que existia, que daí era, por exemplo, as parreiras de uva eram maravilhosas, então quando a uva, dava uva, a gente recolhia sempre aquelas cestas e distribuía pras pessoas porque não tinha o que fazer com tudo, não, não tinha, então a gente tinha...

C: Era muita fartura, né?

13'54" A: Não, olha, era... E esse lado, era muito, muito italiano, a comida, tudo, né? Isso era bem, bem... 
C: Então em casa tinha a tradição da comida. Apesar de não falar a língua, a comida era...

A: É, não, é o hábito, né, da comida italiana, aqueles salames. Nossa, na Itália tem cada salame (risos), maravilhoso, não? Cada presunto, presunto de parma... (risos) C: Só comida boa, não é?

14'21" A: Olha, eu não sei como ele conseguiu, ele se acostumou a isso, mas acho que foi vivenciando tudo, né? E ele tinha, e olha, impressionante, que com esse trabalho ele, ele, ele comprava, constantemente comprava um imóvel, algum, algum terreno. Antigamente existia muita malandragem com esse negócio de vender coisas fora de, fora de São Paulo, mas ele acreditava nas pessoas, ele comprava, mas olha, o que ele deixou de herança pra gente, é uma coisa incrível, muito, muita coisa, a gente tinha uma chácara, maravilhosa, tudo, tudo com o trabalho de alfaiate.

G: Fantástico, né?

15'07" A: Não é? Não é uma coisa que tem que, que, que, que tem que imaginar como é que seria isso, não ganha salário de ninguém, é o seu trabalho, é você e você mesmo, né? E ele trabalhava direitinho, de terno e gravata, todo dia, e só tirava o terno pra poder rachar lenha e pra acender o fogo. Isso eu me lembro muito, muito, muito. Sempre aquela postura, sabe? Elegante, e, com tudo bem arrumadinho, isso, isso daí eu achava muito bonito também, só isso que ele, ele não falava muita coisa.. C: Pra não ficar remoendo, né?

15'51" A: Não, não. Mesmo porque ele já tinha um irmão e uma irmã aqui no Brasil, né?

C: $\operatorname{Sim} . .$.

15'56" A: Então, de vez em quando eles se viam. Mas só não deu pra voltar.

C: Foi... E como a senhora acha que foi, assim? Foi uma dificuldade muito grande, né, ele ficou dormindo...

16’05" A: Nossa! Imagina, dormir na rua. Imagina isso há mais ou menos uns oitenta anos, vamos supor, ou mais até.

C: Até encontrar os irmãos, né? Tudo isso...

16'16" A: Então, encontrar não sei como, porque não existia telefone, não existia nada. Gente, como é que ele, eu fico imaginando como que ele conseguiu chegar, do porto de Santos, pra vir pra São Paulo, quando ele dormiu debaixo de ponte, e viadutos, e como é que ele conseguiu ir até Guaratinguetá encontrar esse irmão, porque não tinha, não existia telefone. 
G: Ele devia ter alguma referência mínima, era uma criança..

16'43" A: É aventura demais, né. É, espírito de aventura.

G: Uma criança.

16'47' A: É, que coragem! Imagina você num navio de carga. E olha, demora quase um mês pra chegar aqui, né? E eu acho que ele veio clandestino.

G: Claro.

17'00" A: Porque ele não tinha dinheiro pra comprar passagem, nem nada, né.

G: E, ele falava, então, desses episódios?

17'08" A: Esse sim, isso daí sim, isso a gente acompanhava, isso a gente sabia.

G: E o que a senhora lembra?

17'17" A: Dessa história, isso sim. Mas, assim, falar assim, da família dele, ele procurava não falar, tanto que eu te falei, né, quando ele recebeu a cartinha... ele recebia cartas da família, né? E, aí ele começar a chorar, aquilo foi pra mim uma coisa que ficou aqui, sabe? Que, imagina, imagina você pensar que, que você não viu sua mãe. Você saiu com treze anos e nunca mais viu sua mãe. Porque o italiano é muito chegado à família. É muito, muito família, então aquilo pra ele foi a, uma coisa. E outra coisa, imagina você mandar dinheiro. Ele mandava, mandava um pouquinho mas mandava pra mãe.

C: Era uma motivação a mais, né, pra ele trabalhar, cada vez mais.

18'08" A: Por isso que eu também, fiz muita coisa, resolvi fazer, e minha filha também, foi, isso fica dentro da gente, né, a gente herda, mas a inteligência dele era uma coisa inacreditável, e o que eu tenho de livros lá em casa, que eram dele, é uma coisa impressionante. Imagina, você ler um livro de psicologia. Que esquisito, né?

C: Já é complicado, em outra língua...

18'35” A: Psicologia da infância. Olha só, que coisa, né? Tá toda lá, a coleção toda lá, bonitinha, que eu guardei lá.

G: Era um curioso.

18'44" A: Hã?

G: Ele era um curioso

18'46" A: Era, era...

G: Um autodidata...

18'48" A: Pois é, e falar corretamente o português, escrevia direitinho, acho que foi uma aprendizagem, né? E ele tinha muitos amigos, lógico, as pessoas que trabalhavam com ele, as pessoas, ele se relacionava muito bem com as pessoas... 
G: Mas ele chegou a estudar então, aqui no Brasil?

19’08” A: Não!

G: Não formalmente...

19'10" A: Não estudou, não. Foi à custa, ele mesmo

G: Autodidata.

19'15" A: Autodidata. Lendo, né? Lendo, lendo e lendo. É incrível. É uma coisa que, eu fico imaginando que isso, acho que eu jamais teria essa coragem, né? É que antigamente era assim, o Brasil era uma, uma aventura, né? Uma coisa assim, que todo mundo, era um sonho, né? Cê vê que tanto é que, que tem italianos no Brasil demais, né? Principalmente no sul, né?

G: É, aqui em São Paulo também.

19'48" A: No sul tem uma cidade, lá no sul, que se chama Nova Trento

G: Sim.

19'53" A: E só tem italianos lá, impressionante, os hábitos são todos, todos, tudo, tudo, tudo, tudo, mesmo aqui também, né? É impressionante como tem, né.

G: No interior também.

20'06" A: É, no interior, acho que, no Brasil todo, né? E agora tá vindo bastante, viu? Outro dia eu conheci num, um rapaz, acho que ele tá com vinte e seis, vinte anos, conheci num, assistindo esses filmes que tem no Festival de Veneza, e ele também, ele veio da Itália pra cá, pra trabalhar, aqui no Brasil, e fala um português corretíssimo e faz só três meses que ele tá aqui, vê? Tá aqui, e a intenção dos italianos é, é essa, eles acham que o Brasil é um, é um, tá, tá muito bem, entende? Porque como eles tão muito mal, então aqui é um sonho pra eles.

C: Uma nova oportunidade, né?

20'49” A: É uma nova oportunidade, né? Então tá vindo muito, bastante mesmo.

C: $\mathrm{E}$ tem uma postura de acolhedor também, né, o Brasil?

20'59" A: É, ai é que tá, nossa, é incrível, viu? E o italiano gosta disso, por exemplo, é engraçado que na Itália existe uma diferença assim, por exemplo, os italianos do norte, eles são mais arrogantes, eles não são muito assim, mas os italianos do sul, gente! Eles falam com você. Uma vez eu fui pra, eu fui pra Nápoles e eu não sabia onde é que eu ia parar, onde que eu ia dormir, enfim, perguntei pruma, pruma moça, eu tava sozinha, eu faço tudo sozinha também, aí ela, ela, ela fez questão de me levar pro lugar, foi lá e me levou, eles adoram conversar, bem diferente, o que é o contrário aqui do Brasil, né? 
C: $\operatorname{Sim}$

21'42" A: É o contrário, mas todos eles são gente boa, não tem assim, não posso reclamar, eu acho que

C: Acho que, por essa relação do Brasil ter recebido tantos italianos, né, é como se fosse meio irmão quando chega lá, não é?

21'58" A: É, é. Eu fiquei impressionada, porque eu fui assistir àquela, uma palestra lá do A. B., lá no, no Círculo Italiano. Quando eu cheguei lá, olha, eu pensei que tivesse na Itália, porque não tinha uma pessoa falando português, nada, nada, nada, nada, que co-, e ele é de uma simpatia, também! Até tirei uma foto com ele, ele é muito simpático. Não, tá tendo muito evento de italianos aqui, né?

G: Muitos.

22'29” A: Muito, muito mesmo. Eu já, partici-, participo de quase todos, quando tem eu vou. Esses festivais, também, são muito interessantes, né? Também vi um no (inaudível) que é os vinte anos sem Fellini, também tem filmes muito bons. Não, então tem muita coisa, a gente vê pelos, por exemplo, cursos de italiano, você vê o que tem de gente fazendo curso de italiano. E é gente nova, não é, é, sabe por quê? Eu tô fazendo pra poder ir pra lá também, então é bem, bem diferente, mesmo. Nossa, eu falei demais né?

C: Não, a senhora pode ficar à vontade. Se a senhora quiser contar um, uma história. 23'11" A: Não, se você quiser perguntar. O que você quiser perguntar, você pode.

G: (inaudível) não tem mais pergunta?

C: Não, tinha, é, como você acha que é ser italiano, mas... a pergunta seria, como você acha que foi ser italiano aqui em São Paulo, né? Mas a senhora (inaudível).

G: É, mas talvez. É talvez ela possa dizer como ela se sente com esse resgate, hã, da cultura do pai. Porque ela falou, você disse um pouco, a senhora disse...

23'43" A: Pode falar você

G: (risos) A senhora...

23'46” A: A senhora não, a senhora tá lá no céu.

G: Você disse que você assimilou muito essa...

23'53" A: Incrível, isso sem aprender nada, porque eu também morava no interior. G: Exato.

23'58" A: Sem aprender nada. É o, a, o interesse meu, entende? Porque eu herdei isso, muito, eu sou muito parecida, muito, muito. Eu era a filha, sou a filha mais velha, né, então eu herdei muito esse lado dele, impressionante. Quando, as primeiras vezes 
que eu fui pra, pra Itália, nossa, eu pegava um trem e ia embora, não queria saber quando, pra que lado eu tava indo e nem quando voltava. Pegava uma mochilinha, botava nas costas e me mandava. Então, por quê? Porque eu, eu herdei esse lado dele, né, que nem a minha filha também, não é, mas, incrível, viu? Agora, as outras pessoas da família, ninguém vem mais pro Brasil, só veio mesmo esses três, né, e nunca ninguém teve interesse em vir passear no Brasil.

C: Conhecer...

24'49” A: Conhecer, tal, não. Porque é complicado, né? Muito complicado. Já pra ir pra lá, quase todo mundo, os meus primos, por exemplo, filhos desse meu tio mais velho também já foi, vão sempre pra Itália, mesmo a minha mãe, uma vez a gente, levei a minha mãe até o porto porque ela ia conhecer uma pessoa, um parente do meu pai, que tava de passagem pelo Brasil, então ela foi lá. Não, eu tenho, inclusive, nessa família, hã, do meu pai, lá nessa região, tem uma pa, uma parente, não sei se seria prima de segundo ou terceiro, que ela, ela trabalha na, no Consulado Italiano, é, então ela tá sempre, assim, atenta a tudo, né?

G: E, e da família do seu pai, esses seus tios. Você tem contato?

25'43” A: Não, então, ele já faleceu há muito tempo, nossa...

G: Já faleceram, mas, assim, eles contavam? Eram dois?

25'49" A: É.

G: Dois tios.

25'51" A: É, só que uma tia morava no Rio de Janeiro, então era difícil falar com ela. G: Mas esse tio, ele...

25'56" A: Ah, esse já, falava sempre italiano, ele não falava português

G: Isso, e ele contou alguma vez alguma história, você lembra de alguma coisa?

26'04" A: Não, também. Incrível, né? Mas ele também morava numa casa assim, maravilhosa, numa chácara cheia de plantas, mas ele não falava, ele falava tudo em italiano. Eu ia muitas vezes passar férias lá com ele, tudo...

G: Ele era um pouco mais velho?

26'20" A: Era, bem mais velho.

G: Bem mais velho que o seu pai.

26'23" A: É, nossa, se o meu pai tivesse vivo, imagine, se eu tou com setenta e seis, imagina, ele tava com mais de cem anos, né. Então, não tem como.

G: Obrigada 
26'33" A: Mas eu vou me lembrar, eu não vou esquecer nunca. O que que eu poderia...

G: Ah, mas eu acho que em síntese é isso, né? É porque quando tem uma lembrança mais nítida, quer dizer, do pai contando alguma coisa, realmente, mas isso é significativo, também, o fato dele não falar.

26'54" A: Ele não falava.

G: Isso pra gente é muito significativo.

26'55" A: Não, é uma coisa impressionante. Eu falo que a única coisa que ele fazia era receber as cartas e ler. E esse que ele recebeu, eu tava sentada do lado dele, olha, eu me lembro tudo, sentada do lado dele, no sofá. Ele começa a ler a carta e chora. E sumiu a carta. Agora, eu fiquei muito chateada, foi com a minha família, porque tudo o que era do meu pai, eles deram fim em tudo, porque o que eu pude pegar eu peguei e trouxe pra mim, pra cá, mas, por exemplo, essas cartas tavam todas lá, tavam todas lá. Sumiu, deram fim em tudo.

G: Que judiação.

27'30" A: Eu não entendo, porque nenhuma irmã minha é, é, é ligada a, porque também, somos em cinco, mas nenhuma irmã, irmão meu é ligado à Itália também.

C: Só a senhora que...

27'46” A: Não, só eu, incrível, viu? E uma sobrinha é que foi estudar na ltália, fez curso lá, ela, ela, ela se formava médica, (inaudível), essa região aí que, que o meu pai nasceu, na universidade, que tem uma universidade de Salerno muito boa, mas lá, olha o resto. Eu é que passei pra eles a história da cidade onde, onde, o lugar onde o meu pai nasceu, esse lugar que chama Penta. Ninguém, ninguém nunca se interessou por nada. Não é estranho? Por que eu?

G: É, uma ligação com o seu pai.

28'25" A: E como eu tenho a mesma ligação com a minha neta italiana.

G: Exatamente.

28'29" A: Acho que é incrível, ela e eu, nós temos uma coisa impressionante. Essa menina, tudo o que, ela tem dez anos, tudo o que ela vê de bonito, ela fala poxa, mamãe, ai, a vovó ia gostar tanto de ver.

G: (inaudível)

28'47" A: É, não, mas ela também, a gente tem essa, essa afinidade muito grande, incrível, incrível, incrível. Desde que ela nasceu.

C: E ela tá lá na Itália, e a senhora aqui, e tem essa ligação 
28'59" A: E eu aqui. É a mesma coisa se ela morasse na minha casa. Porque a gente se fala pelo Skype, né. Mas é, não é uma coisa engraçada? Ela também tem essa, essa. Mas o resto da minha família, nunca, nunca ninguém se interessou. A minha filha também tem a cidadania italiana, eu consegui a cidadania italiana, porque senão a minha filha não podia morar lá, né, você tem que ficar, tem que ficar indo e voltando, indo e voltando. Mas só isso, ninguém, ninguém, ninguém. Por que será, não? Gente, ele deu, é um legado pra gente tão maravilhoso, gente, se a gente tem, o que a gente tem de educação a gente tem que agradecer a ele, né? Não é? Porque ele podia ter posto a gente pra trabalhar em sei lá no que, não é? E nada, eu estudava em colégio de freira, colégio particular (risos), é, e que não é barato. Como é que ele conseguia, não? Ah, eu fico admirada. Admirada e vou ficar o resto da minha vida. Eu penso, as vezes eu paro, penso, penso tanto nele, é incrível, viu? Não dá pra gente esquecer, não dá pra esquecer. Mas essa dele não falar, ele não falava nada da Itália. Única coisa, era a plantação de café. Nada, de falar, mesmo, não. Cê vê, tanto é que ele falava, não falava italiano, falava português. Tanto, escrevia, escrevia em português, mandava sempre carti-, cartãozinho no meu aniversário, sabe? A gente era muito, muito, muito, muito, muito unido. Que coisa, não?

C: E a senhora tá passando isso, né? Pros netos.

30'45" A: Ah, com certeza, não, o que eu puder divulgar. Eu só tô triste porque não achei alguns documentos que eu tinha, que eram superinteressantes. Eu devo ter guardado tão escondidinho, que já revirei a minha casa inteira.

G: Ah, mas um dia acha, né.

30'59" A: Mas eu tenho que achar. Agora, essa da minha família ter dado um sumiço em tudo foi uma coisa muito triste. Muito, muito triste, né?

C: $\operatorname{Sim}$

31'10" A: Não! Sumir tudo. Tava tudo lá. Quando, eu tenho até, inclusive, uma, uma cartilha de, né, de português, acho que ele comprou pra gente estudar, o português. Não, tudo dele, era tudo em português. Agora, essa reunião que ele fazia era muito interessante, que era só de, de italianos, e ele que presidia aquela, as sessões. Só que, então, eu tentei um dia ir pra lá pra procurar, mas já não tinha mais, já tinha acabado. Mas durou muitos anos, viu.

C: E em Taubaté

31'46" A: Em Taubaté. É, eles se comunicavam aqui com São Paulo. E era muito interessante. E ele, e foi ele que criou isso daí. 
G: Então, apesar dele não falar, (inaudível)

32'01" A: Não, tinha...

G: Ele não renegou, na verdade ele...

32'05" A: Não, ele falava assim, como eu moro do Brasil, eu tenho que falar o português.

G: É, é uma forma de, de defesa...

32'12" A: Então, mas esse se, essa, acho que era um círculo italiano, viu!

G: $\operatorname{Sim}$

32'16" A: Que ele ti..., criou isso lá. Eu lembro que na minha casa tinha até as cadeiras das reuniões que eles faziam. Eles faziam reuniões constantes. Porque era um jeito dos italianos ali do interior poder se comunicar, né. Não como como a gente tá aqui que tem essa facilidade. Imagine isso há uns 100 anos atrás.

C: É verdade. Fazer uma reunião dessa (inaudível).

32'39" A: Né, é incrível, mas eles faziam. E ele que organizava. (risos)

G: É ótimo né, C. (inaudível)

32'47' A: Cê quer saber mais alguma coisa?

C: Se a senhora quiser contar alguma coisa marcante, assim pra gente. Uma coisa que marque bastante.

32'57" A: Não, isso que eu te falei que foi o fato dele não ter conseguido voltar, né. Dele me acompanhar a minha vida toda também, em tudo o que eu fazia, ele me acompanhava, pra ver se tava tudo correto.

C: Isso a vida inteira, né?

33'12" A: A vida inteira. Não, imagina, eu fui morar sabe onde quando eu vim trabalhar em São Paulo? Lá em São Caetano, eu fui morar perto da estação de trem lá do Brás. Numa pensão. Ele foi até lá pra ver a pensão. Então, eu também não conhecia nada de São Paulo. No entanto eu pegava um ônibus, um trem, um não sei o que, e ia parar lá em São Caetanos (risos)

G: Chegava, né?

33'37" A: É. Não, mas eu já fiz muita maluquice também, com esse negócio quando eu viajo fora, de aventura. Eu adoro me perder, acho uma delícia.

C: Conhece outras coisas né.

33'47" A: É. conhece né. Então isso aí é, é, é uma herança que eu herdei dele. O espírito de aventura. E isso eu acho muito bom. Né. E a independência também. Que 
eu sou muito independente. Ai meu Deus, eu não queria ser assim. (risos) Mas eu sou.

C: Mas arrisca e vai acontecendo.

34'08" A: Enquanto eu puder, eu vou cuidar da minha vida sozinha. Não, de jeito nenhum. Cê acha? Não dá né. Eu vou ver se eu acho mais alguma coisa, quando você me chamar, eu, eu...

C: $\operatorname{Sim}$

34'25” A: Mas aque-... aquele documento é fabuloso, não é?

C: É muito, muito importante.

34"29" A: Gente, olha. O discurso, o discurso dele.

C: O quanto ele gostava, né, do Mussolini...

34'37' A: Quanto né...

C: $\mathrm{E}$ o respeito

34'40" A: Não, a foto que tinha na sa- na nossa sala de jantar. (risos) Era uma coisa. Imensa. A minha mãe ficou com tanta raiva, quando ele faleceu minha mãe jogou no lixo (risos). Jogou fora, jogou fora. Nossa, eles enfrentaram muitas guerras, muitas revoluções, não? Que coisa, não? Impressionante...

$\mathbf{N}$ : Aquele outro senhor que tava aqui também. Ele falava muito bem do Mussolini.

35'05” A: Também? Ai...

N: Porque o Mussolini deu a casa pra família. O Mussolini que transformou onde eles moravam, que era charco, coisa, e urbanizou.

35’18” A: Olha só! E por que que agora os italianos não gostam dele?

N: Então...

35'24" A: Por que ele era comunista?

N: Não, o Mussolini ele, ele se envolveu na Segunda Guerra junto com Hitler e com o Hirohito que é o japonês.

35'36" A: Ah, verdade!

$\mathrm{N}$ : E com outro país que também ninguém lembra muito, mas que na época ajudou, que foi a Hungria,

35'44" A: Cê sabe que agora...

N: Que eles compunham o eixo.

35'46" A: É isso mesmo. É isso mesmo, porque eu tinha, ano passado, não esse ano, eu fui conhecer, eu fui até uma montanha, eu acho que tem uns 3500 metros, onde tem uma cruz que, e tem um, um lugar ali, que tá bem abandonado, uma pena, é onde 
teve a se, a se, a se, a primeira ou a segunda guerra mundial, é a guerra, era, como é que chamava. Austro-húngara, austro-húngara. Tem a cruz lá em cima. Só que o lugar ali tá bem abandonado onde tinha o, como é que chama? Como é que fala, o forte.

N: E ainda é na Itália?

36'26” A: É, Itália.

N: É naquele cruzamento lá em cima que é a Hungria e Áustria.

36'30" A: Sobe, sobe, sobe, sobe, e tem aquela cruz lá em cima. E aí do lado tem aquele, aquele forte ali que tá, que eu acho uma pena, tá totalmente abandonado. Ninguém vai lá. E ali que teve, que foi a primeira ou foi a segunda?

N: Primeira Guerra Mundial.

36'51" A: Devia ter uma placa lá...

N: É... F. Ferdinando, que era o príncipe da Hungria.

36'56" A: Então, eu tinha, eu tirei até foto desse lugar ali. Impressionante, viu. E a gente chega lá. E tem gente que leva flor ainda.

N: Então. É, aí, os des..., os desmembramentos da guerra.

37'11" A: Eles sofreram muito...

N: O fato do Hitler ter feito o que ele fez. Então, o capital ser concentrado na mão de muitos judeus há muito tempo, né. Que, assim, os judeus, primeiro eles tavam na Alemanha, eles mantiveram a economia da Alemanha até um certo momento que não foi possível. Eles depois tiveram que mudar pro Estados Unidos. O que tem de ale, o que tem de judeu com sobrenome alemão.

37'44" A: (risos)

$\mathbf{N}$ : Sabe, é, é, assim, porque eles sustentavam a economia, né.

37'50"A: É

N: Os judeus eles, na sua tradição o judeu ele não desenvolveu aquela coisa de ter propriedade. O judeu ele tinha que, de repente fugir.

38'02" A: É. Eles tavam sempre fugindo, né.

N: Um povo marcado por diásporas. Então, o judeu ele tem que culti-, que cultivar que coisas né, joalheria, porque no bolso você leva 5 fazendas.

38'14" A: Que coisa, não?

N: E sabedoria. Medicina. Aonde o judeu for que ele é médico, ele vai, vão precisar dele.

38'23" A: Pois é, você vê. 
N: Cê tá com dor, cê não vai perguntar, cê é árabe, cê é judeu? Não, tá com dor. 38'28" A: (risos) Impressionante.

$\mathrm{N}$ : Então, que a História ela é feita de impli, milhares de implicações.

38'34" A: Os alemães também, os alemães também, também ficaram bem, né? Os alemães?

N: Sim

38'41" A: Aliás, os alemães, a Alemanha, o único país que ainda tá conseguindo sobreviver

$\mathrm{N}$ : Que mantém

38'46" A: a essa crise do Euro. É a Alemanha. Porque o resto tá numa situação terrível, hein. Eu posso falar porque eu vejo, eu presencio tudo isso. Tá muito ruim, viu.

N: É, o problema lá foi o Hitler. A figura do Adolf Hitler. Que inclusive...

39'04" A: Aahh... Por isso que, agora tô entendendo.

$\mathbf{N}$ : Devemos a ele a Alemanha ter perdido a guerra. Ainda bem que tinha o Hitler, porque os comandantes alemães no meio da guerra queriam tomar certas decisões que o Hitler falava, não quem manda aqui sou eu. Invade não sei o que, invade...

39'24" A: Então agora eu tô entendendo

$\mathbf{N}$ : Hitler. A coisa não vai, se a gente tomar certas decisões a gente vai perder a guerra. "Eu sou o Führer, eu mando". Se você manda, então chegou um momento que o Hi..., que eles propuseram que eles fizessem um pacto, um pacto não que já tinha feito com (inaudível), um acordo com a Europa ocidental.

39'48" A: Ocidental, né.

N: Pra concentrar todas as tropas contra a Rússia. O Hitler disse não, vai continuar mantendo dois frontes, o fronte do ocidente e o fronte do oriente.

39'59" A: Impressionante, né.

$\mathrm{N}$ : E aí não teve como.

40'01" A: Que coisa, não.

N: Então a, o Hitler acabou com tudo, até com a própria Alemanha, né. Você não pode falar de Hitler na Alemanha. Eles não querem. E o Hitler nem alemão era, era austríaco.

40'13" A: Você não pode abrir a boca pra nada. Aliás, não pode falar nada em lugar nenhum, viu. (risos).

N: É, sim. 
40'20" A: Tem que ficar muito quietinho.

$\mathrm{N}$ : Exato.

40'23" A: Não, agora eu tô entendendo porque, porque que não gostam do, do, do Mussolini. (risos).

N: Ah, aqui no ocidente. porque quem é, assim, quem conseguiu reverter a situação do totalitarismo que o Hitler impunha, a juventude fascista e tal, foram os americanos, foi o Churchill que é o grã britânico, o Roosevelt.

40'48" A: E porque que ele tem esse nome, Dutch.

N: Dutch, hum... aí eu já não sei.

40'53" A: Isso que eu queria saber.

G: Acho melhor interromper.

N: Ah sim.

40'57" A: Nossa, a gente tá falando demais, (inaudível).

G: Não, eu falo pela sala, que a gente reservou até...

41'03" A: Nossa senhora

$\mathrm{N}$ : Eu tenho que descarregar as coisas. Mas 


\section{APÊNDICE J - Transcrição da entrevista 10}

C: Tá certo seu J. O senhor quer uma água, alguma coisa?

0'03" J: Não

C: Não? Tudo bem?

0’04" J: Não, não, não;

C: Tá certo (inaudível). Tá certo seu J. O senhor fica à vontade. Se o senhor quiser começar falando de como eles chegaram.

0'13" J: É, então, seria melhor pra encaminhamento mais adequado da entrevista, C, você ir arguindo, né.

C: Certo

0'19" J: E de, conforme a pergunta, eu vou até me estender um pouco, posso falar até de (inaudível). Então cê pode...

C: Mas, quanto a chegar, né, foi em 45 quando eles chegaram, com 45 anos.

0'30" J: Então, a informação que eu tenho, que meu bisavô, G B, ele tá registrado com a casa do imigrante, que ele chegou aqui no dia 8 do 12 de 1982. Né.

C: (inaudível)

0'44" J: E lá consta que ele tinha 45 anos de idade e, a época, o registro era muito rudimentar, e só consta que ele era marido, não consta o nome da minha bisavó, dos meus avós e dos meus tios avós. Então só consta isso, não consta nem o nome do navio, talvez, e aí merece de um estudo mais aprofundado pra saber disso daí, né.

C: Sim

01'07'J: Hãa

C: O senhor imagina que eles, é, em Santos que eles chegaram?

01'13" J: Então, eles chegaram em Santos, porque a sistemática a época, o que eu li, é que faltava mão de obra no Brasil, né. Depois que o, os escravos deixaram de ser escravos, né, os africanos, faltou mão de obra principalmente pra trabalhar na, na lavoura do café, do café. Então ele já veio contratado da Itália, foi feita a triagem aqui em São Paulo, ele já foi contratado na Itália pra trabalhar numa fazenda em Botucatu, pra onde que eles foram. Não sei que fazenda que foi, única coisa que eu sei que meu pai nasceu em uma fazenda em Botucatu. O meu pai nasceu em 1911, né.

C: (inaudível)

01'57" J: O::, o J B, que era meu avô, esse nasceu na Itália, que veio junto com meu bisavô, e nasceu em 1888 em Údine, na Itália, que é a norte da Itália, divisa com a 
Áustria. Então, então eles foram pra, pra São Manuel, Botucatu, que é aquela região próxima ali, e depois, eram colonos, carpiam café, serviço bruto, e eles eram extremamente trabalhadores. E foram crescendo, (inaudível) a relação entre o patrão, o proprietário, e o colono era, era muito próxima, era muito boa. E eles tiveram condição de crescer na vida.

C: Eles produziam muito na (inaudível)

02'41" J: É, eles produziam e eles conseguia ter vida própria dentro da propriedade. Não sendo proprietário, mas ele tinha a, a criação dele, a plantação dele, ele era um colono no sistema antigo de colônia, né. $E$ aí depois eles se dirigiram, já como proprietários, para Promissão. Aí o G já tinha falecido, aí só foi o meu avô, o J B, o meu pai, foram pra Promissão, uma cidade do interior do estado de São Paulo. E mexer com comércio de café e comércio de arroz. Posteriormente, eles foram pra uma cidade chamada Vera Cruz, paulista, perto de Bauru, perto de Marília, aonde ele se casou com a minha mãe, e eu nasci lá, em Vera Cruz Paulista. Eu sou o quinto, né, eu sou o quinto descendente.

C: Certo

03'31" J: Então, basicamente, agora, o meu avô, veio com, tinha um irmão, chamado Umberto $B$, que também ficou em Vera Cruz, e tinha as minhas tias-avós, que eu, eu não lembro o nome, eu não tenho ciência do nome delas, né.

C: Uhum.

03'49" J: Mas eram famílias numerosas, né. Então o sistema a época era só registrar o G, ou uma pessoa só, um chefe da família. Os demais membros não, não estão citados, né.

C: Algo primitivo, né. E muita gente chegando no mesmo tempo.

04'05" J: É, você imagina uma organização, há 140 anos atrás, aproximadamente, né, ou 130 anos atrás, né.

C: Até a forma de registrar, deve ter se perdido, por ser um negócio bem simples, né. 04'19" J: Agora, eu sei que as condições que eles vieram, eles saíram da Itália. O grande problema foi vencer na vida, ou se manter vivo, vamos dizer assim. Que a Itália passava uma crise tremenda. Eles eram, vamos dizer, o meu bisavô, ele era colono lá na Itália, só que o colono italiano, ele tinha uma vida paupérrima, eles viviam mal, comiam mal, muita doença. Então eles vieram, é o que eles falam, pra fazer a América. Né. Partes (inaudível) o Brasil, parte foi pra Argentina, e parte foi pros Estados Unidos, 
de uma forma geral, né. Mas eles vieram pra fazer a América pra poder crescer, pra poder viver. E eles passavam fome.

C: Sobreviver, né?

05'03” J: Eles tinham problemas gravíssimos. Aqui no Brasil, eles tinham oportunidade de trabalho. E tiveram, e cresceram, tanto é que, é, hã, a (inaudível) italiana aqui no Brasil foi um sucesso, pra eles ou pro Brasil, né.

C: Sim, então, se beneficiou né.

05'18” J: É

C: Mas dentro da casa do senhor, assim, essas histórias todas que o senhor, tudo isso que tá contando agora, foi o seu pai que passou?

05’27' J: Não, eu conheci o meu avo J B.

C: O avô.

5'29" J: O meu avô J B, eu inclusive participei das coisas que ele gostava, né. Eu pescava com ele, ele era pescador. Eu fui em várias pescarias com ele. Ele era muito bravo, uma disciplina muito forte, né, mas tinha uma habilidade muito grande, e eu vi ele várias vezes de jogar boccia.

C: Ah...

05'49” J: E jogar bisca também, né. Bisca é um jogo de baralho, tipo o truco, né, mas eles chamava de bisca. E ele usava, ah, alguns termos em italiano, principalmente quando era pra xingar.

C: Quando ficava bravo.

06'01" J: É, ele usava né, então (inaudível)

C: (risos)

06'05” J: Mas eu sei algum. (risos), então ele falava uns nomes, assim, mas era só nisso, ele não falava em italiano, só algumas expressões, assim, que ele tinha que falar com mais, hã, mais decisão, né, mais rígido, mais bravo.

C: Pra se expressar melhor era o Italiano

06'19" J: É mas falava o italiano. Então o que- agora a minha a minha tia Dirce B se formou inclusive aqui na USP ela fez letras também além de fazer história natural aqui na USP ela fez letras e ela foi pra Itália... ela foi pra Itália... falava italiano fluentemente e foi na nossa reg- foi visitar os parentes que ainda devemos falar- ter lá em Udine na Itália lá né...

06'45' C: O senhor conviveu com essa tia em casa ou não? 
06'48' J: Não, a tia ela morava lá em Marília e eu morava em Vera Cruz que é uma cidade perto e ela faleceu muito cedo né...mas os meus avós o J B eu tive bombastante relacionamento com ele né... na minha fase que eu tinha doze treze anos eu acompanhei bastante ele... principalmente nas pescarias né...e ele tomava vinho todo dia...

\section{7'08' C: Todo dia?}

07'09' J: É todo dia eu lembro que ele tomava vinho no almoço no jantar ... e ele... a característica dele é que ele sempre de paletó...

C: Olha só...

J: Paletó... e quando saia à rua... a cidade era pequena... ele punha chapéu né...

C: Conservava os costumes...

J: É, ele punha o chapéu, tomava vinho todo dia... usava paletó e...e... sempre bem vestido, bem arrumado... porque naquela época em Vera Cruz... nós tínhamos uma máquina de café... benefício de café...chama-se cafeeira B... essa que foi assim a- e mexeram sempre com fazenda de café também né... Meu avô inclusive fazia vinho ele se orgulhava muito do vinho dele...

C: Cultivava a uva dele?

07'52' J: Cultiv-... Ele tinha uma propriedade pequena lá em Vera Cruz ele cultivava vinho, fazia vinho e a turma para agradá-lo falava que o vinho era bom (risos)

C: (risos)

J: Mas não era, é que ele não cobrava, ele dava de presente (risos)

C: Então não dá pra reclamar (risos)

08'06' J: Mas não, ele falava que o vinho dele era lacrima christi, olha o nome que ele pôs.

C: Nossa, bem humilde né?

J: Mas não tinha nada de lágrima de cristo, é, o nome foi pensado, mas o vinho não era de boa qualidade... talvez não porque ele não quisesse... mas as cepas antigamente não tinha tecnologia... a época... ainda mais em Vera Cruz que não era uma região vinícola... não era um Rio Grande do Sul que tinha clima e condições né... Aliás... o clima... Vera Cruz... Marília... o clima adverso às uvas na época... talvez hoje tenha algumas cepas adaptadas lá né...

C: Adaptação...

08'40' J: Mas não tinha... lá não era... ele fazia porque fazia... isso já vem do pai dele né...mas ele cultivava isso daí né... 
C: Cultivava pro próprio consumo e dava de presente...

J: E dava de presente para os amigos...

C: E todo mundo gostava

J: E eu lembro que ele reclamava do preço da rolha...

C: (Risos)

J: Não sei por que... eu acho que a rolha importada... acho que ainda é né... a garrafa era bra- nacional né... mas a rolha ele reclamava do preço da rolha né... e ele não cobrava... ele dava. Mas é isso né que me-... que passa assim. Tem mais coisa né, devagarinho eu lembro... à mesa, ele...ele usava guardanapo... mas não aqui no colo...era aqui...aqui né...na frente... para não espirrar a pasta...

09'26" C: Ele estava sempre bem vestido né?

J: É...mas para não sujar a camisa né...e o macarrão espirra né...guardanapo tem muita gente que põe aqui né...

C: Tem... tem

J: Aqueles filmes antigos a gente vê o sujeito pondo ou alguém põe né... mas se põe aqui no colo (inaudível) né... se bem que o colo italiano é aqui né...

C: $\operatorname{Sim} . .$.

J: Colo, pescoço é aqui...

C: Hoje em dia nossos restaurantes são um pouquinho mais...mais... sofisticados... tem né... vem dobradinho assim né...você amarra como um babador mesmo...

09'51" J: É...mas não vê muito não... vê em algum lugar... mas ele usava todo dia...

C: Ele tinha uma tradição e tanto...

J: E eu lembro... eu lembro a austeridade dele com a família...ele era um verdadeiro chefe né... eu acho que... o...o patriarcado naquela época imperava mesmo. Eu lembro que minha avó Teresa que era de origem italiana também... o sobrenome dela era Forte... e ela era de São Manuel... ela não falava muito...

C: Tinha um respeito né?

10'21" J: Respeito...e os filhos obedeciam meu avô (inaudível)... um negócio militar... muito rígido na disciplina...

C: Tinha...

$\mathrm{J}:$ O que ele falava era...

C: $\mathrm{E}$ isso seu pai também conservou depois?

10'36" J: Não... já foi mais...na verdade...

C: Que bom né... 
J: Eu já tive uma educação mais...

C: Mais razoável...

J: É...mas sempre teve disciplina em casa né... e eu procuro manter também com minha família... mas sempre um... melhor melhor né...

C: Tem que adaptar à época né...

$\mathrm{J}$ : É... às vezes é conversa com o filho... o filho fala à mesa... os filhos não falavam à mesa... não falavam... que falava era um ou outro... o mais velho mas não... e sempre o filho mais velho é quem tinha quase tudo da administração... no caso dos negócios do meu pai... o filho mais velho que era meu pai Alcides B... que recebia todas as incumbências né... os demais eram serviços menores e as mulheres então...

C: Nem um pouco?

J: Não... não... não tinha nada... administração dos negócios... não... era só o homem e o mais velho... o primogênito... que o italiano fazia questão de o primeiro filho ser homem... é o orgulho né... era importante...

C: Era questão de honra né?

J: Era importante... era importante o primeiro ser homem né...

C: E... o... o legal também é essa estrutura toda até na hora de comer né... hoje em dia num- muitas famílias não preservam isso... de todo mundo se reunir... se sentar 11'51" J: É... muita disciplina e eu lembro... inclusive... pra gente assim... se sentava à mesa quando tinha-... era maiorzinho... 12 ou 13 anos... tinha muita disciplina $e$ ordem... não podia fazer bagunça ali... e ele oferecia vinho pra gente...

C: Nossa...

J: É... ele fazia... embora minha mãe talvez não quisesse... mas ele oferecia e dizia... não... toma... é pra tomar vinho... tomava um- um copinho de vinho...

C: Engraçado né... será que era pela questão da saúde né...

J: Não... o italiano toma vinho sempre né... desde o- o trabalhador italiano toma vinho desde cedo...

C: É o combustível né?

J: Quando ele vai ao trabalho... quando ele trabalha na lavoura... no campo... ele toma vinho... talvez seja um vinho mais fraco... um vinho mais leve... mas que ele toma vinho... ele não toma muita água... sabe... ele toma vinho... toma vinho... e... o dia inteiro não- toma... mas...

C: Como a bebida principal né... 
J: Como alimento né... como alimento... a bebida principal do italiano é vinho... mas eu tomava desde pequeno... e minha mãe dava por outro motivo... pra nós éramos em 6 né... ela dava sangria... sangria já era pra gente dormir mais cedo quietinho pra não fazer tanta bagunça (risos)... vai dar uma amortecida né...

C: (risos) acalmar a criança...

13'01" J: É... põe um pouquinho de açúcar... (inaudível) ah... uma coisa que tinha que ter muita observância... é o respeito ao pão... o pão é coisa sagrada... talvez isso venha de religião...

C: O corpo né... de...

J: É... o pão... você tinha que observar... o pão não se cortava com a faca... não podia cortar com a faca... se tinha que fazer com a mão... com a mão... normalmente é tipo esses pães italianos duros né... e na época esses recursos de padaria não... no interior se fazia pão... ou se fazia em casa né... mas e... o importante... além de não se usar faca... você nu::nca... era pecado capital... você botar o pão de cabeça para baixo... isso daí você...

C: Era imperdoável...

13'43" J: Imperdoável... se não... pior que muitas vezes era uma agressão à família italiana você colocar o pão na forma errada... então ele tinha uma posição certa...que pão tem lado né (inaudível)... a parte de cima e a parte de baixo...

C: É... a parte que corta né...

J: Não é a parte que corta... é tá no formato dele... tem a parte lisa e a de cima é meio cascorenta... vamos dizer assim... meia...

C: É aquela parte que... dá uma cortadinha para ele assar e fica o desenho...

J: É... então... o pão de cabeça para baixo... mas não sei... sabe essas coisas que a gente vai aprendendo... eu lembro que tinha a polenta...tinha polenta...

C: Vocês cantavam uma música também da polenta? (Risos)

J: Não... não...não...não não... não...

C: Mas era tradição sempre? Entendi...

J: Não... num num num lembro de cantorias... lembro de alguns termos... como falei para você... algumas palavras em italiano... normalmente para admiração ou para xingar né... mas-

14'41" C: Interjeição né? O jeito de-...

J: O jeito de um-... um jeito bem italiano de falar né... com as mãos... gesticulado né... isso é típico do italiano né... 
C: Sim... é automático né... não tem como falar né... a mão já vai...

J: É... faz parte né? A mão é uma maneira de falar...

C: Certo e...

J: Então C... assim que eu... é dessa maneira...

C: Então da língua mesmo o que o senhor teve contato foi...

15'07' J: Foi muito pouco né... aí depois eu sou engenheiro agrônomo... sou formado em Piracicaba... trabalhei em fazenda de café de gado e não tive... agora eu comecei me interessar por cinema... comecei me interessar por cinema... ah...meu filho é cineasta... diretor de cinema... fiz curso de cinema... especialmente cinema italiano... fiz alguns cursos... e faço aqui ainda na USP cinema italiano especificamente com a professora Eloína Ribeiro sobre a máfia né... já estamos no segundo ano... e vou continuar...

C: $\operatorname{Sim} . .$.

15'47' J: E vou continuar... inclusive no terceiro ano que estou fazendo aqui na USP o trabalho que foi... relacionado ao trabalho que a professora solicitou a Bruna... nós fizemos sobre os diretores italianos... com os respectivos filmes... nós falamos só cinco ou seis... o tempo era curto né...

C: $\operatorname{Sim} . .$.

J: Nós falamos sobre cinco ou seis diretores italianos do (inaudível) filmes famosíssimos...

16'14"' C: Na casa do senhor hoje então... o que tem de italiano mesmo é que...

J: Só lembranças...

C: Só lembranças?

J: Só sobrenome e lembranças né...

C: Sim... tem que...

16'23" J: E...aí...como eu me interessei por cinema italiano e eu estou com tempo agora... eu planejo ir para Itália viajar... né... ir para Itália... então provavelmente o ano que vem eu vá à Itália

C: E o mais interessante agora... é mais interessante ainda né... ter lá o contato com a... com o cinema... a língua né... que o senhor estuda... tudo isso vai ser... uma viagem para aproveitar muito mais né...

J: Porque a língua italiana não é porque eu tenho descendência italiana... não... mas das línguas... inglês eu sei falar né...algumas línguas eu (inaudível) castelhano... mas o italiano realmente é a língua... é a língua mais bonita de se ouvir... é a mais 
maravilhosa... não sei... ela é uma língua mais simpática... mais alegre nas expressões...

C: É especial demais né?

J: É... ela tem... umas características grandes...

C: Independente da descendência... o senhor escolheu o italiano por achar bonito mesmo?

J: $\operatorname{Sim} \ldots \operatorname{sim} \ldots$

C: Valorizado?

J: Sim... e eu acredito que seja né...

C: Demais...sim... e como o senhor analisa assim a... o jeito que o Brasil acolheu todos os italianos... o seu bisavô... seu avô... o senhor acha que como que eles se acostumaram aqui? Se foi muito difícil no começo... tanto para a cultura né quanto pelo trabalho né que eles vieram fazer...

17'45' J: Eu tenho a impressão que o Brasil foi feito para a Itália e a Itália para o Brasil né?

C: Irmãos separados na maternidade...

J: É... eles foram muito bem recebidos... eles foram fazer um trabalho duro... difícil... mas eles corresponderam... hoje a colônia italiana no Brasil... eu tenho a impressão que é a maior fora da Itália... e em São Paulo eu acredito que 30 ou 40 por cento tem a descendência italiana né...e eles sobressaíram em vários setores né... na música... na comida... na culinária... nas indústrias... na agricultura... nas artes de uma forma geral... a presença italiana é grande... né...

18'34' C: Em ambas as partes foram beneficiadas muito né...

J: Perfeitamente... e a... e hoje o número de brasileiros que visitam a Itália eu não sei... talvez... mas grande porcentagem é brasileiro...alguns foram para a Argentina... alguns italianos na época foram para a Argentina... o meu avô veio para cá e alguns foram para a Argentina e outros foram para os Estados Unidos e também cresceram... C: Sim...

J: E cresceram bastante... e hoje quem visita a Argentina o sobrenome italiano lá predomina...predomina...e nos Estados Unidos casos negativos ou positivos de qualquer maneira um nome italiano sempre surge lá... não é...

C: Sim...

J: Mas a população italiana...

C: Inclusive no cinema né... 
J: Sim... também... principalmente em cinema né... a população italiana me pare- me parece a população... na Argentina é quase igual a do Brasil né... população de argentino- argentino com a descendência italiana é enorme na Argentina... quase igual o Brasil... tá bem semelhante... e nos Estados Unidos também... eu não sei vamos dizer... avaliar... mas de qualquer maneira são três países né que a imigração foi forte e a sequência né... as descendências se fixaram e progrediram... basicamente é isso...

20'00" C: Tá certo senhor J... se o senhor quiser contar mais alguma coisa...

$\mathrm{J}: \mathrm{C}$ eu até gostaria de falar mais coisas se eu soubesse né... mas tudo o que eu sei é isso... hã... não tenho... a família $B$ existe vários $B .$. tem uma em Analândia que é perto de Birigui... tem outro $B$ que é diretor do Palmeiras que é professor da Unicamp que foi ministro né... e tem nosso $B$ lá de... que é de Botucatu... então são três $B$ e eles não são parentes... que eu saiba não... e eu gostaria até de entrar em contato com o B daqui professor né... pra ver se a origem dele é de Udine também... não sei... talvez seja... no mais... pra ver a árvore certinha né... agora o que eu gostaria que...que a USP... vamos dizer... tivesse meios de aprofundar mais na vida dele né... C: $\operatorname{Sim} . .$.

21'02" J: Ou até investigar... [C: o histórico né?] lá na cidade dele... trazer mais informação pra gente... porque se a história... história se tem que relatar [C: voltar no tempo] descrever...porque o meu bisneto não vai saber quem era o bisavô dele e nem o bisavô do bisavô...

C: Né... lá atrás né... por isso também a importância do projeto... de resgatar agora e documentar isso né... para ficar guardado... para continuar a história... os costumes... se não o tempo passa e as coisas vão ficando...

J: Sim... e o Brasil é relativamente novo de história... a gente fala de 130 anos...140 anos...é praticamente nada... muito pouco... né... em termos de história de uma forma geral...

21'50" C: Exatamente... então tá certo senhor J... muito obrigada...

J: Obrigado você

C: Obrigada pela contribuição com a foto, as conversas, tudo... vou tentar também conversar com as professoras se a gente puder buscar mais informações e tiver alguma via de acesso e passar para o senhor.

J: Se eu puder também e se eu souber de algo que eu possa acrescentar posteriormente farei com o maior prazer... 
C: Sim, continuar o contato, mas está certo. Muito obrigada J: Obrigado você. 
ANEXO I - Carta convite

Objetivo: Colaboração com um projeto de pesquisa universitária.

Caros Senhores e Senhoras,

Estamos conduzindo uma pesquisa cujo propósito é o de estudar, do ponto de vista linguístico, as interações verbais do idioma italiano no cotidiano do imigrante e descendente italianos no Brasil, particularmente no Estado de São Paulo.

Para obter os dados sobre os quais o nosso trabalho necessita da sua colaboração, solicitamos de sua autorização para o uso desses dados lingüísticos, imagens e documentos cedidos ao nosso acervo. Asseguramos e tornamos claro que todos os dados pessoais permanecerão anônimos.

Os dados servirão exclusivamente para finalidade didática, de pesquisa e divulgação científica - seja de nossa parte ou da parte de outros pesquisadores - sendo utilizados para publicações em suportes físicos e eletrônicos. Tal consentimento é facultativo e pode ser revogado a qualquer tempo.

Para manifestar seu consentimento, basta assinalar no quadro abaixo. Caso haja necessidade, estaremos prontamente à disposição para quaisquer esclarecimentos.

Imensamente gratos pela colaboração, saudamos atenciosamente!

Elisabetta Santoro e

Giliola Maggio

Docentes de Língua Italiana

Suellen Bellentani da Silva, monitora do projeto.

F.F.L.C.H.

Universidade de São Paulo

Autorizo o uso de meus dados sob as condições supra citadas e específico:

1. Autorizo somente o uso da transcrição;

2. Autorizo o uso do áudio e da transcrição;

3. Autorizo o uso das imagens em vídeo, áudio e transcrição.

Nome e sobrenome

$\mathrm{N}^{\mathrm{o}} \mathrm{s}$ de telefone (celular e/ou fixo)

Endereço eletrônico

Local e data

Assinatura 


\section{ANEXO II - Normas utilizadas para transcrição}

\begin{tabular}{|c|c|}
\hline smile voice e parole pronunciate ridendo & £parola \\
\hline risata vocalizzata & hehehe, hahaha, hihihi \\
\hline risata non vocalizzata & $£$ £hh£ \\
\hline $\begin{array}{l}\text { innalzamento o abbassamento improvviso } \\
\text { dell'intonazione }\end{array}$ & / ascendente, $\backslash$ discendente \\
\hline $\begin{array}{l}\text { intonazione finale discendente (NON } \\
\text { NECESSARIAMENTE AFFERMAZIONE) }\end{array}$ & . \\
\hline intonazione finale sospesa & , \\
\hline $\begin{array}{l}\text { intonazione finale ascendente (NON } \\
\text { NECESSARIAMENTE DOMANDA!) }\end{array}$ & $?$ \\
\hline $\begin{array}{l}\text { Intonazione ascendente chiaramente limitata } \\
\text { solo a una parola o a un pezzo di frase } \\
\text { indicare l'inizio e la fine }\end{array}$ & ?parola/pezzo di frase? \\
\hline $\begin{array}{l}\text { inspirazione (lunghezza proporzionale al } \\
\text { numero di acca) }\end{array}$ & .hhh \\
\hline $\begin{array}{l}\text { espirazione (lunghezza proporzionale al } \\
\text { numero di acca) }\end{array}$ & Hhhh \\
\hline testo accelerato & $>$ testo $<$ \\
\hline testo molto accelerato & $>>$ testo $<<$ \\
\hline testo rallentato & $\langle$ testo $>$ \\
\hline testo molto rallentato & $<<$ testo $>>$ \\
\hline basso volume & ${ }^{\circ}$ parola $^{\circ}$ \\
\hline alto volume & PAROLA \\
\hline prolungamento di suono & paro:::la \\
\hline inudibile (una x per fonema) & $\mathrm{Xxxxxx}$ \\
\hline trascrizione dubbia & (parola) \\
\hline troncamento con colpo di glottide & paro- \\
\hline troncamento senza colpo di glottide & Paro \\
\hline pause di meno di $0.2 \mathrm{sec}$ & \# \\
\hline pause più lunghe & \#0_2,\#3_5 (\#\#\#\#\#\# un cancelletto ogni 0.5$)$ \\
\hline enfasi su parola o frase & !parola! !tutta la frase! \\
\hline Latching & $\begin{array}{l}=\text { alla fine del primo turno e inizio del } \\
\text { secondo }\end{array}$ \\
\hline Inizio di sovrapposizione & {[} \\
\hline Fine sovrapposizione & ] \\
\hline time 05.00 mins (ogni cinque minuti) & $\%$ com \\
\hline commenti del trascrittore (in inglese) & $\begin{array}{l}\text { \%com in turni isolati, se all'interno del turno } \\
\text { tra doppie parentesi tonde ((commento)) }\end{array}$ \\
\hline segnali non verbali di approvazione & $\sqrt{ }$ (anche ripetuti se i suoni sono separati) \\
\hline
\end{tabular}

